1980 Survey and Evaluation of

EPRI EM-2193

Volume 3

Project 1940-1

Utility Conservation, Load

Final Report

January 1982

Management, and Solar

End-Use Projects

Volume 3: Utility Load Management Projects

Keywords:

Load Management

Load Control

Thermal Storage 


\section{DISCLAIMER}

This report was prepared as an account of work sponsored by an agency of the United States Government. Neither the United States Government nor any agency Thereof, nor any of their employees, makes any warranty, express or implied, or assumes any legal liability or responsibility for the accuracy, completeness, or usefulness of any information, apparatus, product, or process disclosed, or represents that its use would not infringe privately owned rights. Reference herein to any specific commercial product, process, or service by trade name, trademark, manufacturer, or otherwise does not necessarily constitute or imply its endorsement, recommendation, or favoring by the United States Government or any agency thereof. The views and opinions of authors expressed herein do not necessarily state or reflect those of the United States Government or any agency thereof. 


\section{DISCLAIMER}

Portions of this document may be illegible in electronic image products. Images are produced from the best available original document. 


\section{Survey and Evaluation of Utility \\ Conservation, Load Management, and Solar End-Use Projects \\ Volume 3: Utility Load Management Projects}

EM-2193, Volume 3

Research Project 1940-1

Final Report, January 1982
EPRI-EM--2193 Vol. 3

DE82 007247

Prepared by

ENERGY UTILIZATION SYSTEMS, INC.

365 Plum Industrial Court

Pittsburgh, Pennsylvania 15239

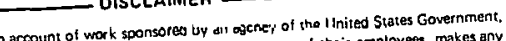
This book was prepared as an accour

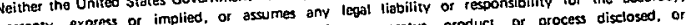
wasranty. express or wuness it any information, apparatus, product, or proces to any specific

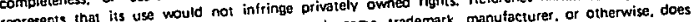

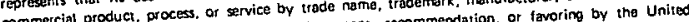
commeressersily constitute or imply its endorsement, recommendat authors expressed herein to not states Government or any agency thereot. The views and opinions of an agency thereot.

Prepared for

OAK RIDGE NATIONAL LABORATORY

Power Systems Technology Program

Energy Division

(under P.O. No. 11X-13644V)

Operated by

UNION CARBIDE CORPORATION

for the

U.S. DEPARTMENT OF ENERGY

ASSISTANT SFCRFTARY FOR CONSERVATION AND

RENEWABLE ENERGY

DIVISION OF ELECTRIC ENERGY SYSTEMS

Electric Power Research Institute 3412 Hillview Avenue

Palo Alto, California 94304

EPRI Project Manager

T. M. Lechner

Residential and Cormmercial Applications Program

Energy Management and Utllization Division 


\section{ORDERING INFORMATION}

Requests for copies of this report should be directed to Research Reports Center (RRC), Box 50490, Palo Alto, CA 94303, (415) 965-4081. There is no charge for reports requested by EPRI member utilities and affiliates, contributing nonmembers, U.S. utility associations, U.S. government agencies (federal, state, and local), media, and foreign organizations with which EPRI has an information exchange agreement. On request, RRC will send a catalog of EPRI reports.

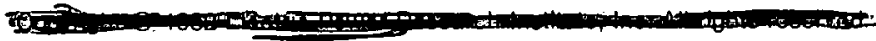 \\ DISCLAIMER}

This report was prepared as an account of work sponsored by the United States Government. Neither the United States nor the United States Department of Energy, nor any of their employees, makes any warranty, express or implied, or assumes any legal liability or responsibility for the accuracy, completeness, or usefulness of any information, apparatus, product, or process disclosed, or represents that its use would not infringe privately owned rights. Reference herein to any specific commercial product, process, or service by trade name, mark, manufacturer, or otherwise, does not necessarily constitute or imply its endorsement, recommendation, or favoring by the United States Government or any agency thereof. The views and opinions of authors expressed herein do not necessarily state or reflect those of the United States Government or any agency thereof.

\section{NOTICE}

This report was prepared by the organization(s) named below. Neither EPRI, members of EPRI, the organization(s) named below, nor any person arting on behalf of any of them: (a) makes any warranty, express or implied, with respect to the use of any information, apparatus, method, or process disclosed in this report or that such use may not infringe privately owned rights; or (b) assumes any liabilities with respect to the use of, or for damages resulting from the use of, any information, apparatus, method, or process disclosed in this report.

Prepared by

Energy Utilization Systems, Inc.

Pittsburgh, Pennsylvania

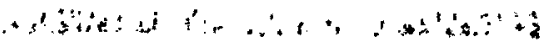


ABSTRACT

This report describes the results of the 1980 survey of electric utility-sponsored energy conservation, load management, and end-use solar energy conversion projects. The work is an expansion of a previous survey and evaluation and has been jointly sponsored by EPRI and DOE through the Oak Ridge National Laboratory.

There are three volumes and a summary document. Each volume presents the results of an extensive survey to determine electric utility involvement in customer-side projects related to the particular technology (i.e., conservation, solar, or load management), selected descriptions of utility projects and results, and first-level technical and economic evaluations. 


\section{THIS PAGE \\ WAS INTENTIONALLY \\ LEFT BLANK}


EPRI PERSPECTIVE

PROJECT DESCRIPTION

This report presents a survey of utility-sponsored projects in monitoring the performance of residential and commercial electricity end-use technologies: thermal energy storage, communication and load control (C\&LC), energy conservation, and solar heating and cooling systems. Technical descriptions of systems and devices representative of each of these four technology areas have also been compiled in this survey. Under TPS 78-807, and more recently under RP1940, EPRI and 0ak Ridge National Laboratory (ORNL) have provided joint funding for a survey of utility activities in these areas. ORNL had the principal responsibility for collecting data on thermal energy storage and C\&LC projects; EPRI was responsible for the remaining volumes of the report. EPRI Special Report AP-1713-SR, a survey similar in nature to this one, was conducted by EPRI on electric utility overall solar energy activities; it included solar power generation technologies.

This report, entitled 1980 Survey and Evaluation of Utility Conservation, Load Management, and Solar End-Use Projects, is the final report under RP1940-1 Task 1 work. Task 2 under RP1940-1, the 1981 survey, is under way.

\section{PROJECT OBJECTIVE}

The main objective of this work was to organize widely dispersed information into a format useful to the utility industry and to the planning of end-use R\&D at EPRI. This information includes:

1. The type and level of energy conservation, load management, and solar end-use activities being conducted by individual utilities

2. Descriptions of the various technologies (systems and devices) being tested 
3. Key results and conclusions of individual projects undertaken

4. Specific utility contacts for obtaining more detailed information

\section{PROJECT RESULTS}

of the utilities responding to the survey, 66 are conducting 130 conservation projects, 127 utilities are involved in 158 C\&LC projects, 59 utilities are performing 86 thermal energy storage projects, and 119 utilities are actively involved in 283 solar end-use projects. Conservation projects include incentive programs, advertising and promotion, evaluation of energy-efficient products and systems, efficiency standards programs, public information programs, and heat recovery programs. Some of the specific technologies under study in individual C\&LC projects include radio, ripple, and power line carrier; in thermal energy storage projects, heat storage in ceramic brick and "cool" storage by ice making are under study. Solar end-use technologies include water heating and active and passive space heating systems.

The comprehensive information source that this survey provides should be of direct interest, to utility personne $i$ involved in energy conservation, load management, and solar end-use programs. It should be of value to them in assessing other programs and in the development and implementation of their own programs.

Utility system planners will be interested in the long-range implications of reduced load growth and improved load factors that the technologies and programs surveyed may have to offer. Some interest may also be warranted from equipment manufacturers and dealers. As these "new" technologies evolve, markets for new products will be developing. 
Finally, the document should also provide EPRI research managers and planners with a useful compilation of information and results to gain insight into successful programs, generic problems, and approaches to $R \& D$ responses to meet utility needs.

T. Michael Lechner, Project Manager Energy Management and Utilization Division 


\section{THIS PAGE \\ WAS INTENTIONALLY \\ LEFT BLANK}




\section{CONTRIBUTORS}

This report was prepared by personnel of Energy Utilization Systems, Inc. with the cooperation of investor-owned, municipal, and cooperative electric utilities - Edison Electric Institute, American Public Power Association, National Rural Electric Cooperative Association and various equipment manufacturers.

\section{Energy Utilization Systems, Inc.} Project Personnel

Robert P. Blevins, Project Manager

Edward J. Doyle, Jr.

Nina I. Abarotin

James C. Nixon

Barry D. Sloane 


\section{THIS PAGE}

\section{WAS INTENTIONALLY LEFT BLANK}


1.0 Thermal Energy Storage $1-1$

Introduction $1-1$

Benefits of TES Systems. $1-3$

System Evaluations $1-6$

TES Projects Summary $1-7$

TES Projects Index 1-10

1.1 Ceramic Heat Storage - Room Units 1-12

Technical Characteristics $1-12$

System Costs and Payback 1-13

Equipment Manufacturer 1-18

Table of Projects $1-19$

Individual Project Summaries $1-21$

1.2 Ceramic Heat Storage - Central 1-24

Technical Characteristics 1-24

System Costs and Payback 1-25

Equipment Manufacturers $1-27$

Table of Projects $1-29$

Individual Project Summaries 1-33

$\begin{array}{ll}1.3 \text { Pressurized Water Heat Storage } & 1-50\end{array}$

Technical Characteristics $1-50$

System Costs and Payback 1-51

Equipment Manufacturer $\quad 1-52$

Table of Projects. 1-53

Individual Project Summaries $1-55$

1.4 In-Ground Heat Storage 1-69

Technical Characteristics 1-69

System Costs and Payback 1-71

Equipment Manufacturer $\quad 1-73$

Table of Projects $\quad 1-75$ 
Section

Page

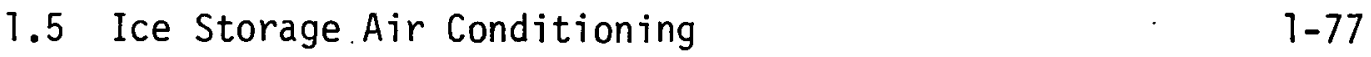

$\begin{array}{ll}\text { Technical Characteristics } & 1-77\end{array}$

System Cost and Payback 1-78

$\begin{array}{ll}\text { Equipment Manufacturers } & 1-82\end{array}$

Table of Projects $1-83$

$\begin{array}{ll}\text { Individual Project Summaries } & 1-87\end{array}$

1.6 Combination Heat and "Cool" Storage 1-107

$\begin{array}{ll}\text { Technical Characteristics } & 1-107\end{array}$

Manufartured Equipment $\quad 1107$

Tablc of Projects 1-109

Individual Project Summaries 1-113

1.7 Special TES Projects 1-128

Technical Characteristics $1-128$

$\begin{array}{ll}\text { Manufactured Equipment } & 1-129\end{array}$

Table of Projects 1-131

Individual Project Summaries 1-133

SECTION 2 2-1

2.0 Communication and Load Control . 2-1

Introduction $2-1$

Benefits of Controlling Load 2-1

C\&LC Projects Summary $\quad 2-10$

C\&LC Projects Index 2-13

2.1 Radio

$2-18$

Technical Characteristics 2-18

System Costs 2-20

Equipment Manufacturers 2-25

Table of Projects 2-27

Individual Project Summaries $2-35$ 
Technical Characteristics

System Costs

Equipment Manufacturers

Table of Projects

$2-79$

Individual Project Summaries

2.3 Power Line Carrier

Technical Characteristics

System Costs

2-101

Equipment Manufacturers

2-103

Table of Projects

$2-105$

Individual Project Sumrnaries

2.4 Combination Radio \& Power Line Carrier

Technical Characteristics

System Costs

Equipment Manufactuer

Table of Projects

Individual Project Summaries

Technical Characteristics

System Costs

$2-139$

Equipment Manufacturers

Table of Projects

Individual Project Summaries

2.6 Local Control

Technical Characteristics

Equipment Manufacturers

Table of Projects

Individual Project Summaries

2.7 Miscellaneous \& Special Projects

Equipment Manufacturers

Table of Projects 


\section{THIS PAGE}

\section{WAS INTENTIONALLY \\ LEFT BLANK}


TABLES

Table

$\underline{\text { Page }}$

1-1 Wholesale Equipment Prices 1-13

1-2 Heating and Cooling Data Summary 1-14

1-3 Base System Energy Use 1-15

1-4 Payback Period Derived For a Given $\Delta R$ Ceramic Room Heat Storage

1-5 Ceramic Heat Storage - Room Units Project Summary

$1-25$

1-7 Payback Period For a Given $\Delta \mathrm{R}$ Ceramic Central Heat Storage

1-8 Ceramic Heat Storage - Central Residential Projects Summary

1-9 Payback Period Derived For a Given $\Delta R$ Pressurized Water Heat Storage

$1-51$

1-10 Pressurized Water Heat Storage - Residential Projects Summary

$7-53$

1-11 Pressurized Water Heat Storage - Commercial Projects Summary

1-12 Payback Period Derived For a Given $\Delta R$ In-Ground Heat Storage

$1-72$

$1-75$

1-13 In-Ground Heat Storage Projects Summary

$1-80$

1-14 Payback Period Derived For a Given $\Delta R$ Ice Storage

$1-83$

1-15 Ice Storage - Residential Projects Summary

$1-85$

1-17 Combination Heat and Cool Storage - Residential Projects Summary

1-18 Combination Heat and Cool Storage - Commercial Projerts Summary

1-19 Special Thermal Storage Projects Summary 1-131

2-1 Averaqe Coincident Diversified Demand Reduction Per Water Heater

2-2 Average Coincident Diversified Demand Reduction - Per Air Conditioner 
Table

Page

2-3 Total Per Point Installed Cost of a Radio Control System as a Function of Receiver Saturation

2-4 Radio Projects Summary

2-5 Minnkota Power Ripple System Installed Costs

2-6 Green Mountain Power Ripple Control Total Per Point Cost as a Function of Receiver Saturation

2-7 Ripple Control Project Summary

2-8 Power Line Carrier Projects Summary

2-9 Total Per Point Cost as a Function of Carrier Recelvers Per RLX

2-10 Combination Radio and Power Line Carrier Prnjerts Summary

2-11 Telephone Projects Summary

2-12 Local Control Projects Summary

2-13 Miscellaneous and Special Projects Summary 
INTRODUCTION AND SUMMARY

BACKGROUND

Electric utility involvement in end-use energy conservation and solar projects has increased during the past several years. Reasons for this activity include deferral of capital expenditures for generating capacity, compliance with regulatory commission and government mandates, public relations, and meeting customer information needs. Utility programs in these areas cover an extremely wide range of topics.

For the past several years, EPRI has sponsored surveys of utility energy conservation programs in conjunction with customer-side load management surveys sponsored by DOE. With the increase in utility interest in solar projects, the decision was made to broaden the survey and evaluation of active utility projects to include those dealing with customerside load management, conservation, and solar energy. This volume of the report, Volume 3, presents descriptions and evaluations of load control and thermal energy storage projects. Volume 1 describes customer energy conservation projects, and Volume 2 deals with end-use solar projects.

\section{OBJECTIVES}

The main objectives of this project are (1) to describe the current state of electric utility involvement in conservation, solar, and load management (load control and thermal energy storage) programs directed at the end-user and (2) to provide a first-order evaluation of those systems that have been used sufficiently to provide cost and performance data. The compilation of project descriptions provides a central source of information concerning current utility research, development, and promotion of these systems and presents sufficient detail to allow other utilities interested in the various devices to make decisions about their own projects based on available information. Although the 
evaluations deal mainly with end-user economics, an attempt has been made to provide installed cost information in sufficient detail to allow individual utilities to adapt the results to their own needs. This cost information can also be used to update previous EPRI studies that have evaluated solar energy system viability.

\section{SCOPE}

This effort deals only with end-user projects that are either currently active or recentiy completed. More additional project write-ups are presented here than in previous reports, which indicates an expanding ulility interest in thermal energy storage and communication and load control technologies. While the compilations may not include all utility load management programs, an attempt has been made to be reasonably comprehensive.

Because load management systems for commercial and industrial applications tend to be designed and sized for the specific requirements of the site, most of the evaluations performed are based on residential systems, for which typical systems and costs are more readily obtainable.

REPORT ORGANIZATION

Each of the major sections of the report contains subsections on the various types of systems (e.g., thermal storage devices). A description and evaluation, summary listing, and project write-ups are presented in each subsection. There are several projects that involve both conservation and solar features. In such cases, the project has been grouped into the category most representative of the project's main objectives. For example, a retrofit program for increasing the energy efficiency of existing houses may include weatherization and insulation options and solar water heating options. Such a program would be grouped under Conservation Devices, Systems, and Programs because its main purpose is energy conservation in general. 
A separate summary document has also been prepared, covering all three volumes of this report. The summary contains tables that will allow the reader to locate individual utility projects in the four main categories. 
$5-4$

THIS PAGE

\section{WAS INTENTIONALLY LEFT BLANK}


METHODOLOGY

The project information in this report has been gathered in a two-stage process to, first, identify where new candidate projects exist and, second, gather information on the status of both newly identified projects and those projects described in the 1979 2nd Revised Report. New project identification was accomplished through:

- contact with the various manufacturers of load management equipment;

- mail survey of investor-owned, large municipal, and Rural Electric Cooperative utilities, and state-wide associations;

- review of industry trade journals and newsletters for the prior 24-month period.

One hundred twenty-four telephone interviews were conducted, resulting in the verification of and the collection of information on 84 new projects in the areas of thermal energy storage and communication and load control.

Copies of the 174 project summaries appearing in Sections 1 and 2 of the 2nd Revised Report were mailed to the sponsoring utilities with the request that they provide updated information on their projects. Prior to the established deadline, 112 utility project summaries were updated and 15 project summaries were deleted at the request of the sponsoring utilities.

Information on the technical characteristics, costs, and performances of the various load management systems and devices was collected in a three-stage process:

- 20 manufacturers of load management equipment were contacted in an effort to quantify present or projected hardware costs and to obtain information on advances in hardware technology. 
- In-depth telephone interviews were conducted with 20 electric utilities. The information gathered in these interviews included: details on the installed costs, maintenance costs, reliability, and overall performance of the hardware being tested; consumer acceptance of the hardware; and overall economics of the hardware including incentive payments, special rates, and load reduction potentials of the hardware.

- Personal interviews were conducted with ten electric utilities in an effort to collect more detailed information on the installed costs and benefits of load management hardware. 
Section 1.0

THERMAL ENERGY STORAGE

\section{Introduction}

More than $60 \%$ of the energy consumed by the residential sector provides comfort heating and cooling. Essentially all residential cooling is accomplished by electrical devices, and the percentage of homes electrically heated is increasing. Since space conditioning demands usually coincide with system peak loads, the load management potential of space conditioning is significant. Thermal energy storage (TES) is one means of capitalizing on this load management potential.

Several significant concepts, which are ready or nearly ready for commercialization, have been developed in the application of TES as a method of load control. These are high temperature ceramic heat storage furnaces, pressurized water heat storage, and in-ground heat storage. In addition, several utilities are sponsoring tests of unique systems, such as combined heat and cool storage and systems utilizing unique storage media. The system that has the widest distribution is the high temperature ceramic room heater. This type of system is being distributed commercially in several areas following successful operation in utility-sponsored demonstration projects.

The basic component of any TES system is the thermal energy reservoir, which will absorb or release heat depending on the customer demand. The reservoir storage capacity is the amount of heat that can be absorbed or dissipated, and is determined by the nature of the reservoir material. An important characteristic of this material is the realizable storage capacity per unit volume, or thermal charge density. The higher the thermal charge density, the lower the volume required for the reservoir. 
The charge density depends not only on the reservoir material, but also upon the way in which this material or storage medium is used. Two options are available: heat may be stored with or without a phase change of the storage medium. If a reservoir is to be used for heating, it is charged by the addition of heat, raising the reservoir temperature. Similarly, if the reservoir is to be used for cool storage, it is charged by the removal of heat, thereby lowering its temperature. The amount of energy required to produce a given temperature change in the storage medium (heat capacity) is a characteristic of the material. The higher the heat capacity, the higher the thermal charqe density. Heat absorbed or released without a phase change is called sensible heat. If the storagc medium is a solid ur d llyuld, continued addition of heat may raise the temperature to the melting or boiling point. The reservoir will then remain at that. temperature in epite of continued heat addition until all of the material has undergone the phase change. The result is the absorption of large amounts of thermal energy (latent heat of fusion or vaporization) at a constant temperature. This latent heat may then be withdrawn for heating or cooling by returning the reservoir to its original state. One pound of ice at $32^{\circ} \mathrm{F}$, for example, will absorb 144 Btu as it melts. In contrast, only one Btu of sensible heat is absorbed in raising one pound of chilled water by $1^{\circ} \mathrm{F}$. Phase change allows smaller reservoirs to be used and has the advantage of providing a constant temperature source or sink, which is a useful feature for applications such as heat pump systems. Enthusiasm for phase change storage has been dampened by practical problems. Only the solid-to-liquid phase change has been used successfully. The energy exchanged in this process is called the heat of fusion. Although most of the research projects identified in this area involve water-ice storage, several new systems utilize salts, with a $45^{\circ} \mathrm{F}-57^{\circ} \mathrm{F}\left(7^{\circ} \mathrm{C}-14^{\circ} \mathrm{C}\right)$ phase change range, as the storage material. Storage systems differ in the method used for charging the reservoir. The only systems of interest in this study use electricity as the energy source for charging. The electricity may power a chiller, a 
heat pump, or resistance heaters. The power consumption during charging is the charging demand or rating of the system. This is an important parameter because of the danger of excessive demand from charging. For an eight-hour charging period, the average charging demand will be three times the average heating or cooling demand for a system with 24-hour operation. However, this is somewhat misleading, both because most systems do not normally operate 24 hours a day and because system ratings are generally given as peak load ratings rather than average load ratings. A reasonable rule of thumb is that the average charging demand will be approximately twice the system-rated heating or cooling capacity.

The amount of TES charging during off-peak hours is usually controlled, based on the outdoor temperature. Outdoor temperature sensing is used to determine how long the TES system should be charged, up to $100 \%$ of the allotted time, in order to adequately serve the next day's anticipated heating requirements.

Some TES space heating installations are designed to also provide domestic hot water in order to take maximum advantage of off-peak heating (charging) rates offered by utilities. A thermal storage water heater is a large capacity [i.e., 120 gallons (454 1iters) for residential], very well insulated electric water heater that will supply an entire day's hot water from an eight to twelve hour off-peak charge, without a significant drop in delivery water temperature between charging periods.

\section{Benefits of TES Systems}

The major utility motivation for promoting the use of TES is the load deferral rapahility that can be obtained from TES systems. If a utility has a poor daily load factor (the ratio of average daily load to peak daily load), load management via TES can improve it by deferring loads to off-peak periods, thereby reducing the peak demand while increasing the off-peak demand. 
An increase in daily load factor implies that the peak load is closer to the average load. This means that more of the demand can be provided by more efficient base-load generating units, which operate at more nearly constant conditions, for longer periods of time, using less expensive fuels than peaking units do. Thus, an increase in daily load factor implies an increase in system operating efficiency. Because TES systems are designed to consume most of their energy during off-peak periods, they can be depended on to reduce peak loads, provide a dependable source of peak load reduction, and reduce or defer the need for expensive generating capacity. Costs of new facility construction and maintenance are rising rapidly, making TES an attractive option.

The loads most commonly shifted to off-peak periods via TES systems are space heating, air conditioning, and water heating loads for both residential and commercial buildings. Because the TES systems defer nearly the entire load to the off-peak period, the peak coincident diversified demand reduction available is quite high.

In the case of electric water heaters, a typical average value for coincident diversified demand is approximately $1 \mathrm{~kW}$. (A further discussion of typical values of diversified demand for space and water heating systems is provided in Section 2 of this report.) Thus, a utility can expect about a $1-\mathrm{kW}$ peak load reduction and a resilltant offpeak increase per TES-type water heater.

The deferrable load for an air conditioning or space heating system is somewhat more dependent on the duty cycle that would be experienced at the time of the utility peak. However, it is reasonable to assume that during the period in which a utility needs to reduce its load, the space heating or cooling system during winter or summer, respectively, would be operating at or near 100 percent capacity. A TES system, then, would result in the deferral of the nominal rated heating or cooling loadminus the coincident demand of any TES system pumps, blowers, or back-up systems. 
As an example, for a residential central air conditioning system rated at 3 tons with an EER of 8, the resultant peak demand would be $4.5 \mathrm{~kW}$. Assuming that the TES system uses a pump rated at one-third horsepower $(0.25 \mathrm{~kW})$ for reservoir-to-duct heat exchange and a central blower rated at $0.5 \mathrm{~kW}$, and that this capacity is needed during the peak period, the net per-point demand reduction available is $3.75 \mathrm{~kW}$. Assuming an 80 percent coincidence factor for all systems connected to the grid, the resultant peak coincident diversified demand reduction is $3.0 \mathrm{~kW}$ per point.

As a second example, a residential 50,000-Btu/hr (14.7-kW) electric resistance central heating system may be replaced by a central ceramic TES system, sized so that no on-peak resistance heating is needed. Again, assuming an 80 per cent coincidence factor, and assuming no difference in blower requirements between the two systems, the peak coincident diversified demand reduction potential is $11.8 \mathrm{~kW}$ per installation.

Because the peak load reductions are large and because the resultant off-peak loads may be two to three times higher than the peak reduction, substantial load factor improvement can be realized if sufficient numbers of TES systems are installed. In fact, one New England utility has determined that only 3,000 residential installations of a particular TES-based system would result in a flattening of its daily load curve. This is an illustration of the importance of carefully integrating TES systems into the load base.

An additional benefit of TES systems is that they are normally customer-owned. This shifts the capital outlay from the utility to the consumer. Because TES systems are significantly more expensive than the conventional heating or cooling systems that they replace, utilities usually offer the customer an incentive in the form of a reduced (off-peak) rate for electricity used to charge the system during the off-peak period. 
The magnitude of the incentive that a utility can afford to offer for the installation of such systems is a function of the value to the utility of the peak demand reduction to be realized. The customer's perception of the economic viability of a TES system may be influenced by initial costs, financing arrangements, monthly savings on electricity bills due to the rate incentive, payback period based on system costs and off-peak rate savings, or a combination of several of these factors. Of course, a larger rate incentive results in a larger monthly savings for the customer and a shorter payback period, so that the system becomes economically more attractive. Ihus, the utility must weigh several factors in evaluating the economics of promoting thermal storage. These include the potential size of the peak demand reduction, the value of this reduction (which depends on wholesale power costs and costs of new generation and distribution equipment, among other factors), and the potential trade-off between the rate differential that the utility feels it can afford to offer and the rate differential that is required to make the system economically attractive to the consumer.

\section{System Evaluations}

The remainder of this section is divided into individual subsections for each type of TES system. Each subsection provides the TES system evaluation, consisting of technical characteristics, system costs, simple payback analysis, and a listing of equipment manufacturers. Each is followed by the updated survey results, including a summary table of all utility-related projects dealing with the particular TES system and selected project. summaries for the larger or more technically interesting utility projects.

Evaluations are provided only for systems that are being used in conjunction with electric utility testing, demonstration, promotion, or marketing programs. Similarly, the numbers shown in the survey results sections reflect only utility-related installations. For this reason; the numbers do not represent 
the total current TES market, but rather show utility activity related to the various devices. The survey indicates that there are over 1,700 utility-related TES systems installed nationwide, whereas TES manufacturers' data shows that there are over 7,000 TES systems installed in New England alone.

Technical characteristics and system costs have been obtained from the equipment manufacturers. The simple payback analysis is performed in order to provide a first-level measure of economic viability that can be used as an initial screening technique for eliminating the more obviously uneconomic investments. The payback method can also provide needed information concerning certain sensitive features of an investment.

More sophisticated and comprehensive methods of evaluation could have been used; however, such methods were not justified because the hardware costs of the storage systems evaluated were, in many cases, based on manufacturers' long range estimates, and because distributor markups were assigned at their highest expected markups, coupled with special one-of-a-kind installation labor rates. Thus, the resultant installed storage hardware costs carried a certain level of conservative uncertainty. To further compound the issue by building in the intrinsic uncertainties of more complex analyses would not have been useful and would not significantly affect the relative economic rankings of the systems..

\section{Thermal Energy Storage Projects Summary}

A total of 86 thermal energy storage projects sponsored by 59 electric utilities are described in the following sections. Although many of the projects have not been formally analyzed, experience has been accumulated to support the following hypotheses:

- TES can be used effectively to improve load profiles.

- A TES system will provide dependable, automatic operation producing normal comfort levels. 
- An appropriate rate incentive for electrical energy will be necessary to offset the capital cost of a TES system.

The TES projects included herein vary significantly in the formality with which they are conducted. Some are conducted without monitoring to provide a simple indication of operating success, while others are extensively monitored to determine energy consumption, operating temperatures, outside temperatures, flow rates, etc., of the devices. Most of these tests are neither of sufficient size nor adequately monitored to produce conclusive load and rate research data. Hence, the Department of Energy (OOE) is funding several larger scale heat and cool storage projects with utilities. The utilities participating in these large-scale DOE projects are: Arkansas Power and Light Company, testing 35 ice cool storage systems; Long Island Lighting Company, testing 50 ice cool and 50 . pressurized water heat storage systems; Niagara Mohawk Power Corporation, testing 5 different heat storage systems in 5 identical buildings; Pacific Gas and Electric Company, testing 20 ice cool storage systems; Public Service Electric and Gas Company and United Power Association, testing 30 and 35 ceramic heat storage systems respectively; Virginia Electric and Power Company, testing 40 combined heat and cool storage systems; and Wisconsin Electric Yower lompany, testing a total of 70 ice cool storage systems. One additional project that warrants special attention is American Electric Power Company's test of 70 central ceramic heat storage systems.

While it is expected that TES systems will not be generally installed without a rate incentive, test system installations have been encouraged by offering a variety of inducements. These include compensation for inconvenience, incidental application of special rates such as water heating blocks, donation 
of the equipment to the homeowner at the conclusion of the experiment, and the personal satisfaction of being part of an important project.

The thermal energy storage projects described in the following sections are as follows:

Central ceramic heat storage

Room ceramic heat storage

Pressurized water heat storage

In-ground heat storage

Ice storage

Combination heat \& cool storage

Miscellaneous
23 projects

8 projects

9 projects

3 projects

23 projects

11 projects

9 projects 
INDEX OF SPONSORING UTILITIES WITH TYPE OF TES SYSTEM FOR EACH

The following key is used to identify the type of storage system(s) used by the listed utility in its project(s):

CC - Central Ceramic Heat Storage

RC - Room Ceramic Heat Storage

PW - Pressurized Water Heat Storage

IG - In-ground Heat Storage

IS - Ice Cool Storage

HS. - Conmbinationn Heat and Cool Storage

CS - Comparative Study of Thermal Storage

WH - Water Heat Storage

ES - Eutectic Salts Cool Storage

$\mathrm{CW}$ - Concrete Wall lool Storage

\section{$\underline{\text { UTILITY }}$}

American Electric Power

Arkansas Power \& Light

Baltimore Gas \& Electric

Bonneville Power Administration

Butler Rural Electric Coop

Central Main Power Company

Central Vermont Public Service Corp.

Cleveland Electric Illuminating Co.

Columbus \& Southern Ohio Electric

Commonwealth Edison

Consolidated Edison

Consumers Power

Crow Wing Coop Power \& Light

Dairyland Power Coop

Detroit Edison

Duke Power

Eastern Utility Associates

General Public Utilities

Georgia Power

Green Mountain Power

Gulf Power

Gulf States Utilities

Iowa Electric Light \& Power Co.

Jersey Central Power \& Light

Kansas Gas \& Electric

Kansas Power \& Light
TYPE(S) OF TES

CC
IS
IS
HC

$\mathrm{CC}, \mathrm{RC}$

$\mathrm{RC}$

$\mathrm{RC}$

IG

CC

IG, IS

IS

CC

WH

$C C, R C, I G$

$\mathrm{CW}$

$\mathrm{PW}, \mathrm{IS}$

PW

$\mathrm{HC}$

IS

PW

$\mathrm{PW}$

IS

CC

IS, $\mathrm{HC}$

IS

$\mathrm{HC}$
PAGE(S)

$1-29,33,35$

$1-83,87$

$1-83$

$1-111$

$1-19,29$

$1-19$

$1-19$

$1-75$

$1-29$

$1-75,85$

$1-83,89$

$1-29,38$

. $1-131$

$1-19,29,40,75$ $1-131$

$1-53,55,83$

$7-53,57$

$1-109,113$

$1-83,85$

$1-53,59$

1-53

$1-83,85,91$

$1-29,42$

$1-83,109$

$1-83$

$1-109$ 
UT IL ITY

Long Island Lighting

Metropolitan Edison

Montana Power

Niagara Mohawk Power Corp.

New England Gas \& Elec. Service Co. New England Electric System

North Attleboro Municipal Electric Light Dept.

Northeast Utilities Service Co.

Northern States Power

Northwest Rural Electric Coop Association

Orange \& Rockland Utilities, Inc.

Otter Tail Power

Pacific Gas \& Electric

Pennsylvania Electric

Pennsylvania Power \& Light

Philadelphia Electric Company

The Potomac Edison Co.

Potomac Electric Power

Public Service Electric \& Gas

Public Service Co. of Indiana

Public Service Co. of New Hampshire

Salt River Project

Southern California Edison

Steele Waseca Cooperative Electric

Tampa Electric

Tennessee Valley Authority

Tri-County Electric Coop (Minn.)

UGI Corp.

Union Electric

United Power Association

Vermont Electric Cooperative

Virginia Elertralic \& Power

Wiscons in Electric Power

Wisconsin Power \& Light
TYPE(S) OF TES

PAGE(S)

PW, IS,ES $\quad 1-53,61,83,92,131,133$

$\mathrm{CC}, \mathrm{RC}, \mathrm{HC}$

CC

CS

CC

$\mathrm{RC}$ $1-19,29,111$

$1-29$

$1-131,135$

$1-29$

$1-19$

$\begin{array}{cc}R C & 1-19 \\ C S & 1-131 \\ C C, H C & 1-29,40,109,115\end{array}$

CC

IS

CC

CC, IS, CS

$\mathrm{CC}, \mathrm{PW}$

$\mathrm{HC}$

IS

PW

$\mathrm{HC}$

CC, IS

IS, WH

$\mathrm{CC}, \mathrm{PW}$

IS

IS

CC

ES

$\mathrm{CC}, \mathrm{HC}, \mathrm{CS}$

CC

CC

IS

CC

$\mathrm{RC}$

$\mathrm{HC}$

IS

C.C.
1-29

$1-83,95$

1-29

$1-29,44,83,96,137,138$

$1-29,53$

$1-111,118$

$1-85$

$1-53$

$1-109$

$1-29,46,83,98$

$1-83,131$

$1-29,53,64,67$

$1-83,85,99,101$

$1-85,103$

$1-29$

$1-131,140$

$1-31,109,120,122,131$

$1-31$

$1-31$

$1-83$

$1-31,46$

$1-19$

$1-109$

$1-83,85,105$
$1-31$ 


\subsection{CERAMIC HEAT STORAGE - ROOM UNITS}

\section{Technical Characteristics}

Room electric storage heaters consist of a magnesite brick storage core heated by electric resistance wire coils at night for room heating during the following day. In contrast to heat storage in water, ceramic bricks, despite lower density, have greater heat storage capacity in less space because of the higher temperatures at.tainahle = up to $1200^{\circ} \mathrm{F}\left(649^{\circ} \mathrm{C}\right)$.

Room heat storage units are floor-mounted under a window or against a wa11. Ihcy are available in rlve s1zes, from 2 to 6 kilowatts, with overal1 dimensions of 25.5-inch $(65 \mathrm{~cm})$ height, 9.8 to 12.5-inch (25 to $32 \mathrm{~cm}$ ) depth, and 25.5 to 50.8 -inch $(65$ to $125 \mathrm{~cm}$ ) length, and weigh from 239 to 666 pounds ( 108 to $302 \mathrm{~kg}$ ). Despite the high internal temperatures of these units, the exterior surface temperature does not exceed $140^{\circ} \mathrm{F}\left(60^{\circ} \mathrm{C}\right)$. This is accomplished by utilizing high density mineral wool insulation. Overheating is prevented by a built-in safety thermostat. The level of night time off-peak charging of the unit is determined by a control panel that can be adjusted manually or operated autnmatically by an outdoor temperature sensor. Some installations are equipped with more complex controls programmed to local time-of-day rate schedules.

Inside the room individual wall-mounted thermostats, set to desired temperatures, control the built-in, squirrel-cage fans. Room temperature air is introduced to the fan compartment at the bottom of the case and is partially diverted to flow over the bricks. The balance of the air bypasses the bricks and mixes with the heated air at or near the outlet grill along the front bottom of the unit. Room temperature is thus maintained within $2^{\circ} \mathrm{F}\left(1^{\circ} \mathrm{C}\right)$ of the thermostat setting at all times. When the thermostat is not calling for heat and the fan is not operating, some natural 
convection of air and radiation from the steel casing occurs, thus further tempering and modulating the room temperature.

Ceramic room type heat storage units have been installed in large numbers across Europe. In the United States their use has been limited primarily to New England, but in other areas a few trial installations have been made.

System Costs and Payback

Wholesale equipment prices for various size units, as quoted by two different manufacturers, are listed in Table 1-1.

\section{Table 1-1}

WHOLESALE EQUIPMENT PRICES

Equipment

2-kW Storage Heater

$3-k W$ Storage Heater

4-kW Storage Heater

$5-k W$ Storage Heater

6-kW Storage Heater

Average Price per kW

Central Control
Wholesale Price

Manuf. A Manuf. B

$\$ 400 \quad \$ 406$

$507 \quad 406$

$623 \quad 525$

707.688

$842 \quad 688$

$154 \quad 136$

$312 \quad 225$

One manufacturer has estimated that the installed cost of a room storage heating system averages $\$ 200 / \mathrm{kW}$.

Because a thermal energy storage system represents a significant increase to the consumer in initial and annual owning costs, some rate differential is required in order to produce an annual operating cost saving. This saving in annual operating cost ( $\triangle A O P C$ ) can be used to determine a simple payback period, the concept of which can be readily understood by the consumer in considering purchase of a thermal storage system. 
Before a simple payback analysis can be performed, it is necessary to determine the difference in initial cost ( $\triangle I C$ ) between a TES system and a standard, non-storage system. In the case of a ceramic room system, a comparison will be made with an electric baseboard heating system.

EUS has conducted a computer study that traced the yearly heat gains and losses, on an hourly basis, of an 1100 square foot (102 square meter) NEMA (National Electrical Manufacturers Association) standard home built on a slab, in the Pittsburgh, Pennsylvania area. This study provided base load information and traced the annual heating and cooling loads for this size home using a central electric furnace with central air conditioning, using a zonal resistance heating system with zonal air conditioning, and using a heat pump system. Tables $1-2$ and 1-3, selected from this computer study, show the heating and cooling loads used for sizing the systems and the energy used by the three base systems, respectively. These data will be used in the cost comparisons in this and subsequent analyses.

\section{Table 1-2}

HFATING ANח CONLING DATA SUMMARY

\begin{tabular}{|c|c|c|c|c|}
\hline & \multicolumn{2}{|c|}{ Intal Heat. I nas } & \multicolumn{2}{|c|}{ Total Hoat Gain } \\
\hline & Btu & $\begin{array}{l}\text { Equiv. } \\
\text { kWh }\end{array}$ & Btu & $\begin{array}{l}\text { Equiv } \\
\mathrm{kWh}\end{array}$ \\
\hline Worst winter day & $4.63 \times 10^{5}$ & 135.8 & --- & --- \\
\hline Worst winter hour & $0.285 \times 10^{5}$ & 8.4 & --- & --- \\
\hline Worst summer day & --- & -- & $1.44 \times 10^{5}$ & 42.2 \\
\hline Worst summer hour & --- & -- & $0.157 \times 10^{5}$ & 4.6 \\
\hline Maximum off-peak $12-h r$ load & $2.37 \times 10^{5}$ & 69.5 & $1.20 \times 10^{5}$ & 35.2 \\
\hline Maximum on-peak $12-h r$ load & $2.26 \times 10^{5}$ & 66.0 & $0.24 \times 10^{5}$ & 7.0 \\
\hline
\end{tabular}


Table 1-3

BASE SYSTEM ENERGY USE

\begin{tabular}{|c|c|c|c|c|}
\hline System & $\begin{array}{l}\text { Annual } \\
\text { Heating } \\
\text { Load } \\
\text { (Btu) } \\
\end{array}$ & $\begin{array}{l}\text { Heating } \\
\text { Energy } \\
\text { Required } \\
\text { (kWh) } \\
\end{array}$ & $\begin{array}{l}\text { Annual } \\
\text { Cooling } \\
\text { Load } \\
\text { (Btu) } \\
\end{array}$ & $\begin{array}{l}\text { Cooling } \\
\text { Energy } \\
\text { Required } \\
\text { (kWh) }\end{array}$ \\
\hline Electric Baseboard & $29.3 \times 10^{6}$ & 8580 & $8.6 \times 10^{6}$ & 1260 \\
\hline Electric Furnace & $30.4 \times 10^{6}$ & 8910 & $12.2 \times 10^{6}$ & 1790 \\
\hline $\begin{array}{l}\text { Heat Pump } \\
\text { (back-up resistance) }\end{array}$ & $29.9 \times 10^{6}$ & $\begin{array}{l}5120 \\
(173)\end{array}$ & $12.2 \times 10^{6}$ & 1790 \\
\hline
\end{tabular}

An $8.5 \mathrm{~kW}$ baseboard system was chosen, based on the maximum hourly load shown in Table 1-2. At an assumed installed cost of $\$ 60$ per kW, the $8.5 \mathrm{~kW}$ baseboard system would cost $\$ 510$.

As mentioned earlier, TES systems are generally sized at twice the design heat loss of the particular installation. If the designed heat loss is $8.5 \mathrm{~kW}$ in this example, then the ceramic room system would be sized at $17 \mathrm{~kW}$. Based on the estimated $\$ 200$ per $\mathrm{kW}$ installed cost for this system, the total cost is $\$ 3400$ and the $\Delta I C$ is $\$ 2890$. This study assumes that a reduced, off-peak rate is charged for the thermal energy storage system and a normal base rate is charged for everything else. The use of time-of-day rates for this comparison would require a number of simplifying assumptions and would result in a rate-differential/payback-period relationship similar to that using thermal storage rates.

In order to compute the incremental annual operating cost, a thermal storage rate is assumed, and the following terms are defined:

$$
\begin{aligned}
& A O P C_{\text {Base }}=R_{B} \times \text { (space heating } \mathrm{kWh} / \mathrm{yr} \text { ) }
\end{aligned}
$$

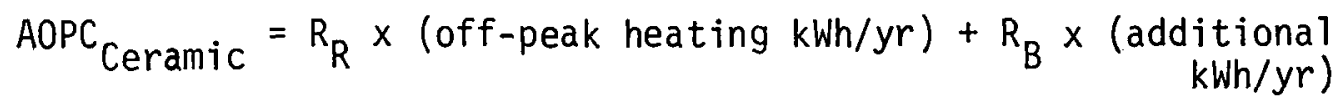


where

$$
\begin{aligned}
& R_{B}=\text { base rate }(\$ / \mathrm{kWh}) \\
& R_{R}=\text { reduced thermal storage rate }(\$ / \mathrm{kWh})
\end{aligned}
$$

For simplicity, it is assumed that only off-peak power is required.

Then

$$
\triangle A O P C=A O P C_{\text {Base }}-{ }^{A O P C} C_{\text {Ceramic }}=\left(R_{B}-R_{R}\right) \times \text { (space heating } \mathrm{kWh} / \mathrm{yr} \text { ) }
$$

or

$$
\triangle A O P C=\triangle R \times(\text { spdce heating } \mathrm{kWh} / \mathrm{yr})
$$

where

$$
\Delta R=R_{B}-R_{R}
$$

The value for space heating $\mathrm{kWh} /$ year, obtained from Table 1-3 for the electric baseboard system, is $8580 \mathrm{kWh} / \mathrm{yr}$. Therefore, $\triangle A O P C=\triangle R \times 8580$

The payback period $(n)$, which is the number of years needed for the annual operating cost savings to balance the higher initial system cost plus the incremental maintenance and replacement costs, is

$$
\mathrm{n}=\frac{\triangle I C}{\triangle A O P C}
$$

For the ceramic room heaters in this example

$$
n=\frac{\$ 2890}{8580} \times \Delta R
$$

This relationship determines the payback period in years for a given base rate - storage rate differential $(\triangle R)$, as shown in Table 1-4. 


\section{Table $7-4$}

PAYBACK PERIOD DERIVED FOR A GIVEN $\triangle R$ CERAMIC ROOM HEAT STORAGE

$\underline{\Delta R(\$ / k W h)}$

.02

.04

.06

.08 $\underline{\mathrm{n} \text { (years) }}$

16.8

8.4

5.6

4.2

The payback periods calculated in Table 1-4 for each $\Delta R$ must be viewed in the proper perspective. These values are only valid within the operating parameters established thus far. For example, the TES system was sized by doubling the designed heat loss. of the home. This relationship assumes an eight-hour charging period per day. If the utility offered a twelve-hour charging period, the size of the TES system could be reduced somewhat, which would result in a smaller $\triangle \mathrm{IC}$ and shorter payback. If the home in this example were located in a colder climate, the total annual heat loss would be higher. This would result in increased $\triangle A O P C$ and shorter paybacks because the $\triangle A O P C$ is directly proportional to the base system energy use.

For the sake of consistency, the operating parameters used in this analysis will be used in all subsequent analyses, whenever possible. This will provide a basis for evaluating the various TES systems relative to each other. 
Ceramic Heat Storage - Room Units - Equipment Manufacturers

U. S. Distribution by Control Electric Corporation 346 Shel lburne Road

Burlington, Vermont 05401

Siemens-Power Engineering Division

136 Wood Avenue South

Isel in, New Jersey 08830

IPI Corporation

P.0. Bux CKS

Johnson City, Tennessee 37601 
Table 1-5

Ceramic Heat Storage - Room Units Project Summary

\begin{tabular}{|c|c|}
\hline utility & conteact \\
\hline $\begin{array}{l}\text { Sutler Rural Electric } \\
\text { cooperative, Inc. }\end{array}$ & $\begin{array}{l}\text { Robert Mainous, Energy Conservationist } \\
\text { (513) } 894-9000\end{array}$ \\
\hline $\begin{array}{l}\text { Central Maine Power } \\
\text { Company }\end{array}$ & $\begin{array}{l}\text { Philip C. Hastings, Research Engineer } \\
(207) \text { C23-3521 }^{2}\end{array}$ \\
\hline $\begin{array}{l}\text { Tentral Vermnnt Publ ic. } \\
\text { Seevice Corporation }\end{array}$ & 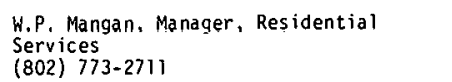 \\
\hline Dairyland Power Cooperative & $\begin{array}{l}\text { Larry H. Thorson, Manager, Energy } \\
\text { consservation } \\
(608) / 788-4000\end{array}$ \\
\hline Metropoli itan Edison Company & $\begin{array}{l}\text { R.M. Spiess, Administrator of Technical } \\
\text { Services } \\
(215) 929-3601\end{array}$ \\
\hline New England Electric System & $\begin{array}{l}\text { R.P. Sakellar is, Director, Load } \\
\text { Management } \\
(617) \text { 366-9011 }\end{array}$ \\
\hline 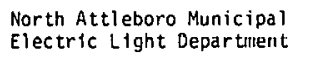 & $\begin{array}{l}\text { John Miller, Manager, Energy Systems } \\
(677) 699-7591\end{array}$ \\
\hline & 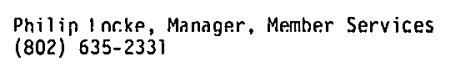 \\
\hline
\end{tabular}

(n)

\begin{tabular}{|c|c|}
\hline Equi ipment & Control \\
\hline AEG & Time switches \\
\hline AEG & Time switch \\
\hline 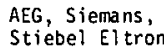 & $\begin{array}{l}\text { Time switch } \\
\text { and ripple }\end{array}$ \\
\hline Siemans & Time Switcc \\
\hline AEG & Time switch \\
\hline AEG & Time switch \\
\hline AEG & $\begin{array}{l}\text { Time switch } \\
\text { with radidio } \\
\text { back-up }\end{array}$ \\
\hline AEG & Time switch \\
\hline
\end{tabular}

\section{inter}

\begin{tabular}{|c|c|}
\hline Sample & Incentive \\
\hline 1 house & To0 rate \\
\hline $\begin{array}{l}8 \\
81 \text { apa tments, } \\
\text { houses }\end{array}$ & Experimental storage rate \\
\hline 18 houses & 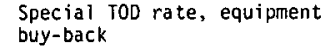 \\
\hline 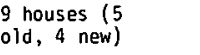 & Off-peak rate \\
\hline 3 houses - & lou rates \\
\hline 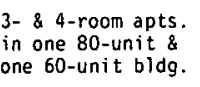 & $\begin{array}{l}\text { Experimental a } \\
\text { filed for too contracts } \\
\text { inate }\end{array}$ \\
\hline 50-unit apt. bldg. & Reduction in demand charges \\
\hline 28 houses & $\begin{array}{l}\text { Special TOO rate } \\
\text { 12:00 a.m. - 6:00 a.m. }\end{array}$ \\
\hline
\end{tabular}

\begin{tabular}{|c|}
\hline TOD meter only \\
\hline 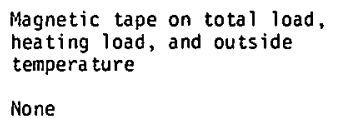 \\
\hline watthour meters only \\
\hline $\begin{array}{l}\text { Magnetetc tave un AEG units } \\
\text { and Too meter }\end{array}$ \\
\hline 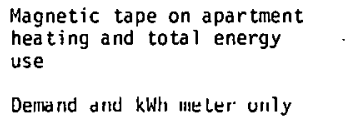 \\
\hline $\begin{array}{l}\text { Magnetic tape on energy use } \\
\text { and temperature in sone houses }\end{array}$ \\
\hline
\end{tabular}

\begin{tabular}{|c|c|c|}
\hline$\frac{\text { Status }}{\text { In service }}$ & $\begin{array}{l}\text { Results/Remarks } \\
\text { Confort excellent. Working well. }\end{array}$ & $\begin{aligned} \text { Contact Date } \\
\text { April 29, } 1980\end{aligned}$ \\
\hline Completed & $\begin{array}{l}\text { Final report due September } 30 \text {, } \\
1980 .\end{array}$ & July 21, 1980 \\
\hline $\begin{array}{l}\text { Completed } \\
\text { March } 1975\end{array}$ & $\begin{array}{l}\text { Custorerers satisfied. Peak load } \\
\text { grovth reduced. System being } \\
\text { promoted. }\end{array}$ & August I, 1978 \\
\hline $\begin{array}{l}\text { Test } \\
\text { continuing }\end{array}$ & $\begin{array}{l}\text { Custoners satisfied. } \\
\text { Ressults exce linent. }\end{array}$ & May 6, 1980 \\
\hline $\begin{array}{l}\text { Test } \\
\text { continuing }\end{array}$ & Prel iminiary report availatle. & May 24, 1979 \\
\hline $\begin{array}{l}\text { Test } \\
\text { continuing }\end{array}$ & 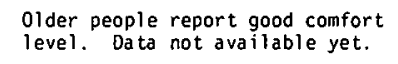 & September $11,198 \mathrm{C}$ \\
\hline In service & $\begin{array}{l}\text { Simiar system for } 12-\text {-unit } \\
\text { building now be ing polanned. }\end{array}$ & October 31, 1980 \\
\hline $\begin{array}{l}\text { Test } \\
\text { continuing }\end{array}$ & $\begin{array}{l}\text { System being promoted. } \\
\text { Unviverstity of of verriont } \\
\text { monit toring. }\end{array}$ & July 10,1980 \\
\hline
\end{tabular}




\section{THIS PAGE}

\section{WAS INTENTIONALLY \\ LEFT BLANK}


CENTRAL MAINE POWER COMPANY

NEW 1980

Edison Drive

Augusta, Maine 04336

(207) $623-3521$

Philip C. Hastings, Research Engineer

SYSTEM: $\quad$ Ceramic Heat Storage - Room Units

SUMMARY: In cooperation with University of Maine and Argonne National Laboratories, Central Maine Power Company has been conducting a 22-residence ceramic brick storage space heating research project. Data collection was completed in June 1980 and a final report will be ready by September 30, 1980 .

EQUIPMENT: $\quad$ AEG ceramic brick heat storage units.

CONTROL: $\quad$ Clock switches that will be replaced by GE IR 70 meters when installations become permanent.

TEST

ENVIRONMENT: A range of residential dwellings, from apartments for the aged to the large home of a university president.

SAMPLE: $\quad$ Eight apartments in a home for the aged. Fourteen single-family houses of various sizes.

INCENTIVE: $\quad$ Experimental storage rate allowing 8 hours charging that was made permanent in April 1980, but to be replaced by a 10 charging-hour load management rate in current rate case.

MONITORING: WR34 three-channel magnetic tape recorder on whole house, and inside and outside temperatures.

INTERVIEW

DATE :

Ju1y 21, 1980. 
STATUS: $\quad$ Data collection completed. Final report due at Argonne National Laboratories by September 30, 1980.

RESULTS: $\quad$ Not yet determined. 
NEW ENGLAND ELECTRIC SYSTEM

20 Turnpike Road

Westborough, Massachusetts 01581

REV ISED 1980.

George P. Sakellaris, Project Manager

SYSTEM: $\quad$ Ceramic Heat Storage - Room Units

SUMMARY: In two apartment houses with 140 total apartments, the builders have installed AEG room units which New England Electric system is monitoring. The same builders have a control group of apartments using straight resistance heat.

EQUIPMENT: AEG 2, 3, and 4 kilowatt units - one per room in three and four room apartments.

CONTROL: Time switches.

TEST

ENVIRONMENT: Three and four room apartments in an 80-unit building in Norten, Massachusetts and a 60-unit building in Warren, Massachusetts occupied mostly by older people.

SAMPLE: $\quad 140$ apartments.

INCENTIVE: Experimental time-of-day contracts off-peak 9 p.m. to 8 a.m.

MONITORING: Tape meters on total use and heating use of some individual apartments.

INTERVIEW

DATE:

September 10, 1980.

STATUS: In service.

RESULTS: $\quad 01$ der people report good comfort level. Monitoring data not yet available. 


\subsection{CERAMIC HEAT STORAGE - CENTRAL RESIDENT IAL}

\section{Technical Characteristics}

Ceramic core central heat storage systems for residential application are similar in function to ceramic room storage systems. In the same manner as room units, the ceramic bricks in the core are heated to high temperatures by coiled electric resistance elements off-peak at night for fan-forced convection heating of the house during the following day. The level of heat stored in the ceramic bricks is determined by a control system that includes a thermostatic device mounted on the exterior of the house and a solid-state controller. Unilike room units, the central ceramic heat storage unit is installed in a central location, usually in a heated basement, and is connected to the return air and supply ducts of the forced air heating system serving the entire house.

Because of the high temperatures [up to $1400^{\circ} \mathrm{F}\left(760^{\circ} \mathrm{C}\right)$ ] of a fully charged core, three types and thicknesses of insulation are used to prevent heat loss and reduce exterior surface temperatures. This level of insulation limits the skin temperature of a fully charged unit to a maximum of $150^{\circ} \mathrm{F}\left(65.5^{\circ} \mathrm{C}\right)$.

The heating elements arc nichrome wire coils of heavy gauge and low wattage density to prevent burn-outs. One element is placed in each layer of bricks.

The 0livene bricks are specially designed for heat storage. The top of each brick is slotted to hold the heating coil and the sides have molded vertical channels, which, when fitted together, form air passages.

In the off-peak charging mode, the heating elements come on in sequence at 45-second intervals. A temperature sensor, mounted on the outside of the coldest wall of the house, sends a signal to the solid-state charge controller, which, in turn, determines 
the amount of heat to be stored for the next day's use. In mild weather, only a partial charging of the heat storage core is required.

In the on-peak heating mode, dampers control the air flow of the system. Air passes directly over the surface of the bricks and mixes with by-pass air in a proportion appropriate for space heating at $120^{\circ} \mathrm{F}\left(49^{\circ} \mathrm{C}\right)$, under the control of a mixed-air thermostat. When the house thermostat is not calling for heat, the dampers are set at full bypass. In the event of inadequate on-peak period heating, a manual button mounted on the unit can be used to activate the heating elements in the storage core.

System Costs and Payback

Wholesale prices for a number of ceramic central heating units of various capacities are shown in Table 1-6. A cost comparison will be made between one of these units and a central electric furnace, sized to meet the loading conditions specified in Table 1-2.

Table $1-6$

CENTRAL CERAMIC HEAT STORAGE SYSTEM PRICES

\begin{tabular}{|c|c|c|c|c|}
\hline $\begin{array}{l}\text { Total kW } \\
\text { Capacity }\end{array}$ & $\begin{array}{c}\text { Storage } \\
\text { kW } \\
\text { Capacity }\end{array}$ & $\begin{array}{l}\text { Night Heating } \\
\text { Section } \\
\text { (kW) }\end{array}$ & $\begin{array}{l}\text { Storage } \\
\text { Capacity } \\
\text { (kWh) }\end{array}$ & $\begin{array}{c}\text { Contractor } \\
\text { Price } \\
\end{array}$ \\
\hline 21 & 11 & 7 & 91 & $\$ 1300$ \\
\hline 31 & 21 & 10 & 140 & 1650 \\
\hline 36 & 24 & 12 & 160 & 1700 \\
\hline 40.5 & 27 & 13.5 & 180 & 1750 \\
\hline 45 & 30 & 15 & 200 & 1800 \\
\hline
\end{tabular}

Based on the sizing data in Table 1-2, the 14-kW storage unit with $7-\mathrm{kW}$ night heating section is selected for comparison with an $8-\mathrm{kW}$ central electric furnace. The installed cost of this electric 
furnace is assumed to be $\$ 400$. Applying markups and installation rates to the central ceramic system similar to those used for ceramic room systems, the installed cost of the $14 \mathrm{~kW}$ central ceramic unit is assumed to be $\$ 1700$. These cost assumptions would yield a $\triangle I C$ of $\$ 1300$.

Using the base system energy consumption data from Table 1-3 and the methods and terminology from the previous section, the annual operating cost savings are

$$
\triangle A O P C=\triangle R \times 8910
$$

and the payback period is

$$
n-\frac{1300}{\Delta R \times 8910}
$$

Payback periods produced by incremental rate reductions are shown in Table $1-1$.

Table 1-7

PAYBACK PERIOD DERIVED FOR A GIVEN $\triangle R$ CERAMIC CENTRAL HEAT STORAGE

$\Lambda R \quad(\$ / k W h)$

.02

.04

.06

.08 n (Years).

$$
7.3
$$

3.6

2.4

1.8 
Ceramic Heat Storage - Central Residential Equipment Manufacturer

TPI Corporation

P.0. Box CRS

Johnson City, Tennessee 37601 
THIS PAGE

\section{WAS INTENTIONALLY \\ LEFT BLANK}


Table 1-8

Ceramic Heat Storage - Central Residential

\begin{tabular}{|c|c|}
\hline utility & Contact \\
\hline $\begin{array}{l}\text { American Electric Power } \\
\text { Company }\end{array}$ & $\begin{array}{l}\text { Dorman Miller, vice President, Customer } \\
\text { Services } \\
(614) 223-1370\end{array}$ \\
\hline $\begin{array}{l}\text { American Electric Power } \\
\text { Company. }\end{array}$ & $\begin{array}{l}\text { Oorman Miller, Vice President, Customer } \\
\text { Services } \\
(614) 223-1370\end{array}$ \\
\hline $\begin{array}{l}\text { Buturer Rural Electric } \\
\text { cooperative, Inc. }\end{array}$ & $\begin{array}{l}\text { Robert Mat nores, Project Manager } \\
\text { (513) } 894-0002\end{array}$ \\
\hline $\begin{array}{l}\text { Columbus \& Southern ohio } \\
\text { Electric Cuinjuany }\end{array}$ & $\begin{array}{l}\text { Will iam 0. Will is, Project hanager } \\
(614)^{4} 464-7680\end{array}$ \\
\hline Consumers Power Company & $\begin{array}{l}\text { Kenneth } L \text {. Baker, Supervisor of Rate } \\
\text { Research } \\
\langle 517\rangle)>88-0550\end{array}$ \\
\hline $\begin{array}{l}\text { Da iryland Puwer Cooperative } \\
\text { (joint with) }\end{array}$ & 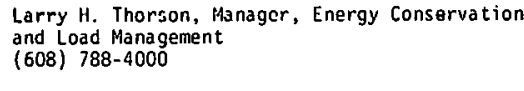 \\
\hline $\begin{array}{l}\text { Morthern States Power } \\
\text { Wisconsin }\end{array}$ & $\begin{array}{l}\text { D.R. Kranzzann, Manager, Consumer } \\
\text { servive } \\
\text { (715) 839-2441 }\end{array}$ \\
\hline $\begin{array}{l}\text { lowa Electric Light } \\
\text { and Power compony }\end{array}$ & $\begin{array}{l}\text { Boo Close, Manager of Market ing } \\
(319) 3_{398-4411}\end{array}$ \\
\hline Metropnli itan Frisson C.mpmony & $\begin{array}{l}\text { Robert M, Spiess, Admini strator, Technical } \\
\text { Services } \\
(215) \text { ( } 921-6253\end{array}$ \\
\hline Montana pover company & 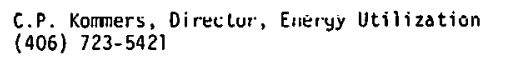 \\
\hline $\begin{array}{l}\text { New England Gas \& Electric } \\
\text { Service Company }\end{array}$ & 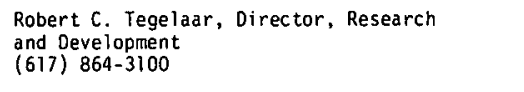 \\
\hline 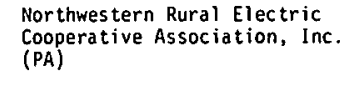 & $\begin{array}{l}\text { Gene e yyer ly, Supervisor, Member Services } \\
(814) 398-4651\end{array}$ \\
\hline Otter Tail Power Cumpally & 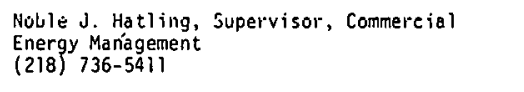 \\
\hline Otter Tail Power Company & 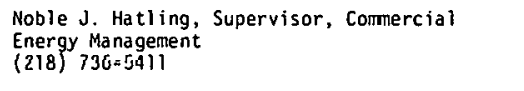 \\
\hline $\begin{array}{l}\text { Paciticic bas and Electric } \\
\text { r.npmany }\end{array}$ & $\begin{array}{l}\text { John s. Cooper, vice President, Cus lumer } \\
\text { Oporatitions } \\
(415) \text { 781-4211 }\end{array}$ \\
\hline $\begin{array}{l}\text { Pensyl lyania Electric } \\
\text { Company }\end{array}$ & 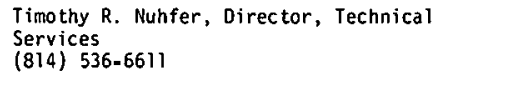 \\
\hline $\begin{array}{l}\text { Punlic Service Electric } \\
\text { and Gas company }\end{array}$ & 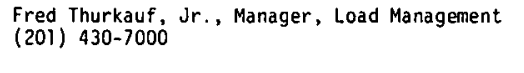 \\
\hline $\begin{array}{l}\text { Public Service Company } \\
\text { of New Hampshire }\end{array}$ & 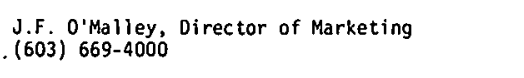 \\
\hline $\begin{array}{l}\text { Steele Waseca Cooperative } \\
\text { Electric }\end{array}$ & $\begin{array}{l}\text { Douglas Hughes, } \\
(507) \text {, } 451-7390 \text { ineer ing Technician }\end{array}$ \\
\hline
\end{tabular}

Equipment

TP1 and Creda

Control Time switch and
thermost tats

sample

somp

Incentive
Experimental Too rate

Experimental too rate and

Time switch and 1 house
thernostats

Time switch and
thermostats

Time switch and
themost tats $\quad \begin{gathered}\text { l house } \\ \text { (enployee) }\end{gathered}$

Too rate

Future too denand rate
and equi inment cost

Time swict and and
thememostats

Time switch and
thermost tats $\quad \begin{aligned} & \text { house } \\ & \text { (employee) }\end{aligned}$

Special rate and excess
installation cost

Excess installation cos
SPCC 8 NSS Share
I00 rate pending

\begin{tabular}{|c|c|c|c|}
\hline Time swilchi & 22 houses & $\begin{array}{l}\text { Tou rate and subsidized } \\
\text { equi prent costs }\end{array}$ & kuh meters on furnace \\
\hline $\begin{array}{l}\text { Time switct and } \\
\text { thermostats }\end{array}$ & 1 house & $\begin{array}{l}\text { Too rate and equipment } \\
\text { cost }\end{array}$ & Magnetic tape on energy use \\
\hline $\begin{array}{l}\text { me rwitch and } \\
\text { mernostats }\end{array}$ & 1 house & Nurne & Béing plamed \\
\hline
\end{tabular}

Time ewitch and
thernos tats

Time switch and
therrmostats

Radio and
therrnostats

Time switch and
thermostats

$\$ 200$ per year

ToO rate and equipment
cost of one

Ton rare and
equipenent cost

Time switch and
thermostats
(rodio loter)

Tine switch ond 1 house
hermostats

Too rate and
equipment cost

$\$ 20$ per month

$\underset{\substack{\text { Time switch and } \\ \text { thermostats }}}{2}$ houses

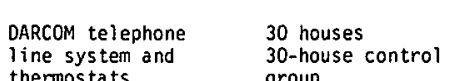

time switch and

Time switch and

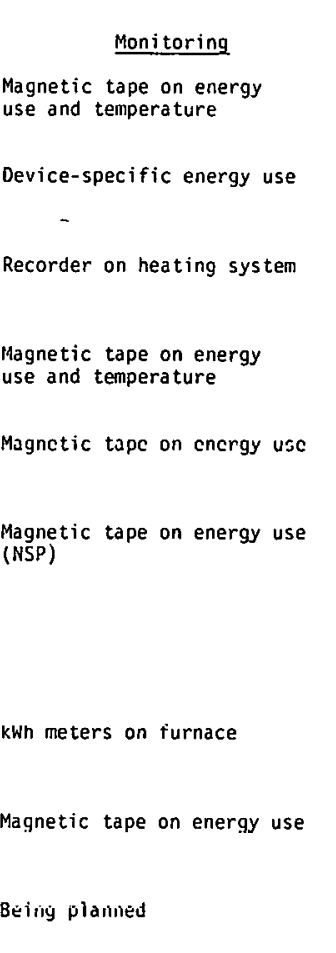

Magnetic tape on energy
use and tenjeratures

Magnetic tape on energy
use $\{1$ home

Magnietic tape on energy use

Magnetic tape on energy use
and air temerature

Magneticic tape nn energy

Magnetic tape on energy
use and temperature

Magnetic tape on energy
use and temperature

Chart meters on eneray use
and core temperature

1 house
(employee)

2 houses

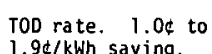

$\$ 10$ per month and
new day/night thermosta

Special contract

4t/knh discount for off-
peak heat ting and water
livating.
Status

Test comple ted

Kesults/Remarks Cus tomers pleased. Test data
has beer analyzed Storage
rates fil iled in 7 states.

$\begin{array}{ll}\text { Iest continuing } & \text { keating satisfactory. } \\ \text { lhrough } 1980-81 \\ \text { early control problems. }\end{array}$

Test continuing Heating satisfactory.

Being install led $\begin{aligned} & \text { Not yet detemined. } \\ & \text { Ihree-yer test. }\end{aligned}$

Test continuing $\begin{aligned} & \text { Heat ing caticfactory. Test } \\ & \text { to end May } 1980 .\end{aligned}$

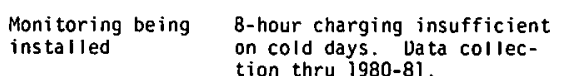

Kecruiting
customers

Test ended
June 1979

Test continuing

Test continuing

Test continuing$$
\text { Soblems. }
$$

Performance good. Three-
yeart test to end late
1980.

Not yet determined.

Test continuing

Hot yet determined.

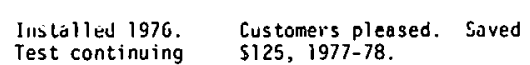

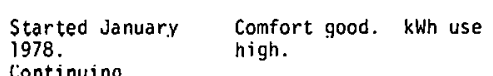

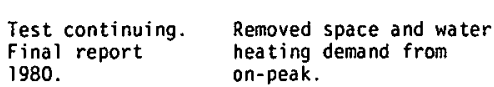

Recruiting
custoners

In service
Oc cober
10.

In service

Not yet determined.
Contact Date

April 24, 1980

April 24, 1980

April 29, 1980

July 2, 1979

April 29, 1980

May 6, 1980

December 2, 1980

May 24, 1979

July 19, 1979

April 14, 1980

June 26, 1979

August 4, 1978

August 1, 1978

September 17, 1980

May 29, 1979

May 29, 1979

Aprii 30, 1980

November 13, 1980 
THIS PAGE

\section{WAS INTENTIONALLY LEFT BLANK}


Table 1-8 (Continued)

\begin{tabular}{|c|c|c|c|c|c|c|c|c|c|}
\hline Utility & conteact & Equi ipnent. & control & Sanple & Incentive & Monitoring & Status & Eesults/Remarks & contact oaste \\
\hline Tennessee Valley Author ity & $\begin{array}{l}\text { Patricia } \mathrm{H} \text { - Harris, Load Managenent Branch } \\
\text { (615) } 755-3591\end{array}$ & TP1 & $\begin{array}{l}\text { Time switch and } \\
\text { thermostats }\end{array}$ & 2 houses & $\begin{array}{l}\text { Equipment price concession } \\
\text { or replacemenent with heat purpp }\end{array}$ & Magnetic tape on energy use & Test continuing & $\begin{array}{l}\text { Heat ing excel lent. } \\
\text { Monit toring continuing. }\end{array}$ & June 4, 1979 \\
\hline $\begin{array}{l}\text { Tri-County Electric Co-op. } \\
\text { (Minnesota) }\end{array}$ & $\begin{array}{l}\text { Joseph S. Ris love, Menber Services Director } \\
(507) \text { 864-7783 }\end{array}$ & TPI & $\begin{array}{l}\text { Time switch and } \\
\text { therrmostats }\end{array}$ & $\begin{array}{l}\text { louse } \\
\text { (co-op direct tor) }\end{array}$ & Too rate & Too meter only & $\begin{array}{l}\text { Installed } \\
\text { June } 1979\end{array}$ & Heat ting excel lent. & July 20, 1979 \\
\hline UGI Corporation & $\begin{array}{l}\text { Frederick J. Hartwigsen, Manager, Consurer } \\
\text { Relalitions } \\
\text { (17) 283-0611 }\end{array}$ & TPI & $\begin{array}{l}\text { Time switch and } \\
\text { thermostats }\end{array}$ & 2 houses & $\begin{array}{l}\$ 1.23 / \mathrm{kH} / \mathrm{moc}-6 \text { months, } \\
\text { equi inment redit, and } \\
\text { To0 rate }\end{array}$ & $\begin{array}{l}\text { Magnetic tape on energy use } \\
\text { anc EPRI -nonit toring of one }\end{array}$ & Test continuing & $\begin{array}{l}\text { Heating excellent: } \\
\text { Monit toring continuing. }\end{array}$ & June'4, 1979 \\
\hline $\begin{array}{l}\text { United Power Association } \\
\text { (Minnesota) }\end{array}$ & $\begin{array}{l}\text { Yance Zenri inger } \\
\text { (612) } 441-3121\end{array}$ & TPI & $\begin{array}{l}\text { Radio and } \\
\text { thermostats }\end{array}$ & $\begin{array}{l}\text { 35 houses } \\
35 \text {-house control } \\
\text { group }\end{array}$ & $\begin{array}{l}\text { \$37.50/40uarter - } 8 \text { quarters. } \\
\text { Equippent } 5700 \text { in escrow. }\end{array}$ & 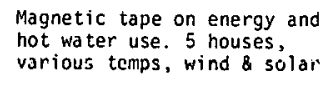 & $\begin{array}{l}\text { Test continuing } \\
\text { from May } 1 . \\
\text { 1980, }\end{array}$ & 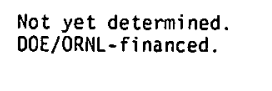 & May 5, 1980 \\
\hline $\begin{array}{l}\text { Wisconsin Power and } \\
\text { ight Company }\end{array}$ & $\begin{array}{l}\text { Dale e. Moody, Director of Consuner Services } \\
(608) \text {. } 2525-3241\end{array}$ & TPI & $\begin{array}{l}\text { Time switch and } \\
\text { thermostats }\end{array}$ & 1 house & $\begin{array}{l}\text { \$25/month plus equipment } \\
\text { (Too rate later) }\end{array}$ & $\begin{array}{l}\text { EPRI monl toring inc luding } \\
\text { weather station }\end{array}$ & Test continuing & Not yet determined. & 980 \\
\hline
\end{tabular}


THIS PAGE

\section{WAS INTENTIONALLY LEFT BLANK}


AMERICAN ELECTRIC POWER COMPANY, INC. 180 E. Broad Street

REVISED 1980

Columbus, Ohio 43125

(614) 223-1372

Dorman M. Miller, Vice President, Customer Services

SYSTEM: $\quad$ Ceramic Heat Storage with Heat Pump - Central Residential

SUMMARY: In one 1,281-square-foot, well-insulated house in Wheelersburg, Ohio, American Electric Power's Ohio Power Company has installed a Creda ceramic heat storage unit supplementing a 2-ton Carrier heat pump. Through a Y-duct connection, stored heat will supplement or replace heat supplied by the heat pump on cold days.

EQUIPMENT: Creda ceramic storage unit. Carrier 2-ton heat pump.

CONTROL: Thermostats and thermistor to sense outdoor temperature in order to determine extent of off-peak heat storage required for following on-peak period.

TEST

ENVIRONMENT: 1,281-square-foot house with 1,050-square-foot basement. Insulation: six inches in walls; twelve inches in ceilings. Windows: double-glazed. Annual heating degree-days: 5,000. Design temperature: Winter $-0^{\circ} \mathrm{F}$ outdoor, $71^{\circ} \mathrm{F}$ indoor; summer- $-95^{\circ} \mathrm{F}$ outdoor, $75^{\circ} \mathrm{r}$ indoor.

SAMPLE: $\quad$ One house.

INCENTIVE: Experimental TOD rate and special price for equipment.

MONITORING: 4-channel WR4 magnetic tape meters measuring time, compressor load, heat pump fan load, Creda resistance elements, and Creda fan load. 
INTERV IEW

DATE:

STATUS:

RESULTS:
April 24, 1980.

Test will continue through 1980-81 winter.

Heating is satisfactory. Some control difficulty was encountered in 1978-79 winter. 
AMERICAN ELECTRIC POWER COMPANY, INC.

180 East Broad Street

Columbus, Ohio 43125

REVISED 1980

(614) 223-1372

Dorman Miller, Vice President, Customer Services

William Coleman, Director of Residential and Commercial Services

SYSTEM: $\quad$ Ceramic Heat Storage - Central Residential

SUMMARY: In 70 homes in five East-Central states, off-peak central heat storage furnace and water heater units were installed in a demonstration project. Objective of the program was to investigate the potential for shifting load to off-peak hours among residential customers. The electrical thermal storage furnaces are installed in parallel with conventional electric furnaces that heat the home during off-peak hours. TPI Corporation of Johnson City, Tennessee, with whom American Electric Power has been working, has designed and built a limited number of the American version of the Creda Ltd. units being used in this project. TPI-produced units have an increased storage charging capacity of $30 \mathrm{~kW}$ as compared to the $14.4 \mathrm{~kW}$ of the Creda units which 1 imited installation to smaller homes. Four homes in this determination have the American version.

EQUIPMENT: Sixty-six 14.4-kW.Creda Ltd. refractory heat storaqe units. Four 30-kW TPI units. S1xty-s1x 10-kW TPI electric furnaces. Four 15-kW TPI electric furnaces. Seventy 4.5-kW 120-gallon A.0. Smith water heaters with loadleveling control.

CONTROL: $\quad$ TPI furnace operates $11 \mathrm{p} . \mathrm{m}$. to $7 \mathrm{a} . \mathrm{m}$. while Creda or TPI storage unit is charging. Furnace and storage blowers will not operate simultaneously. Load-leveling control limits the amount of charge according to the outside and inside temperatures. A 24-hour, 7-day time switch with spring 
reverse controls the storage equipment and selects the on-peak or off-peak register of the electric meter.

TEST

ENVIRONMENT: Single-story home was preferred test site because of simple duct system with low blower head requirement. Homes were chosen from the territories of:

Wheeling Electric Company--5,387 degree-days; $0^{\circ} \mathrm{F}$ design temperature. Coldest day average temperature of $1^{\circ} \mathrm{F}$.

Appalachian Fower Company - Virginia $=4,329$ to 5,121 deyreedays; $0^{\circ} \mathrm{F}$ to $9^{\circ} \mathrm{F}$ design temperatures. loldest day average temperature ranges from minus $5^{\circ} \mathrm{F}$ to $6^{\circ} \mathrm{F}$.

Ohio Power Company--4,620 to 6,079 degree-days; $0^{\circ} \mathrm{F}$ to minus $7^{\circ} \mathrm{F}$ design temperature. Coldest day average temperature ranges from minus $5^{\circ} \mathrm{F}$ to minus $12^{\circ} \mathrm{F}$.

SAMPLE: $\quad 70$ homes. Five units were in operation in winter of 1976-77, balance in 1977-78 and 1978-79.

INCENTIVE: Estimated operating cost savings over conventional electric system is $\$ 130$ to $\$ 315$ per year per house, depending on space heating and water heating requirements. Payback was computed at 2.2 to 5 years for the extra investment. The TPI-Creda packages will be replaced with the TPI Americanproduced storage units during 1980.

MONITORING: $\quad 60$ homes with Sangamo SR-1, magnetic tape, load research recorder in parallel with two register kWh meters on furnace/water heater package. Records integrated energy use over a 24-hour period on either a 15 or 60 minute integrated demand basis. Ten homes with magnetic tape meters to monitor: energy use by storage system, furnace, water heater, and blower; air temperatures and in and out water heater temperatures. 
INTERV IEW

DATE :

Apri1 24, 1980

STATUS:

Tests completed - rates filed in Michigan, Indiana, Ohio, West Virginia, Virginia, Kentucky, and Tennessee to promote ETS installations on a permanent basis.

RESULTS: A detailed survey indicated customers pleased with lower cost and "cozy" warmth. Test data has been analyzed. Cost of future equipment and installation has been determined.

REMARKS: A 120-gallon A. 0. Smith water heater with off-peak charging and charge leveling controls was included. 
CONSUMERS POWER COMPANY

212 West Michigan Avenue

REV ISED 1980

Jackson, Michigan 49201

(517) $788-0550$

Kenneth L. Baker, Supervisor of Rate Research

SYSTEM: $\quad$ Ceramic Heat Storage - Central Residential.

SUMMARY: Thermal storage, as a method of peak load leveling, is being investigated through the use of high-temperature ceramic storage heaters in eight residences. These units are being tested in homes of typical customers. This $\$ 50,000$ project is being funded by Consumers Power as part of a more comprehensive $\$ 1.2$ int17tion load management experimentál program.

EQUIPMENT: TPI 30-kW units.

CONTROL: Time switch for eight-hour charging, 9 p.m. to 9 a.m.

TEST

ENVIRONMENT: Homes of typical residential customers; about 1,500 square feet. Degree-days--6,000 to 8,000 . Design temperature-minus $10^{\circ} \mathrm{F}$.

SAMPLE: $\quad$ Eight homes.

INCENTIVE: Customer not expected to bear unusual cost burden. Consumers Power will pay for installation and excess costs. Free replacement of unsatisfactory systems. Special slurdye rale is $2.743 \$$ per kWh from 9 p.m. to $9 \mathrm{a} . \mathrm{m} .$, plus fuel adjustment. Monthly service charge is $\$ 2.65$.

MONITORING: Two 4-channel data recorders at each test home will be used to monitor the eight installations. 
INTERVIEW

DATE:

April 29, 1980.

STATUS:

All installations completed. Some units are oversized and will be modified. Data collection to end in May 1980.

RESULTS: $\quad$ Not yet determined. 
DAIRYLAND POWER COOPERATIVE

REV ISED 1980

2615 East Avenue South

La Crosse, Wisconsin 54601

(608) $788-4000$

Larry H. Thorson, Manager, Energy Conservation and Load Management

NORTHERN STATES POWER COMPANY

100 North Barstow Street

Eau Claire, Wisconsin 54701

(715) $839-2441$

D.R. Franzmann, Manager, Consumer Service

SYSTEM: $\quad$ Ceramic Heat Storage - Central Residential

SUMMARY: Dairyland Power Cooperative and Northern States Power dre Julntly engaged in a load management project utilizing ceramic heat storage. A $30 \mathrm{~kW}$ TPI ceramic storage furnace has been installed in the home of a Dairyland Power Cooperative employee. The electrical usage of the TPI unit and its effect on diurnal load shifting was monitored in the winters of 1978-79 and 1979-80 and will continue to be monitored in 1980-81. Data will continue to be gathered as residential TOD rates are put into effect.

EQUIPMENT: $\quad$ TPI 30-kW ceramic storage furnace.

CONTROL: $\quad$ Time switch for charging off-peak.

TEST

ENVIRONMENT: $\quad 2,444$ square-foot, all electric residence in La Crosse, Wisconsin. 7,400 heating degree-days. Insulation--walls $\mathrm{R}-18$, ceilings $\mathrm{R}-38$. Footings are insulated and windows are triple-glazed.

SAMPLE: $\quad$ One house.

INCENTIVE: Dairyland Power Cooperative and Northern States Power will share the cost over and above that of a normal heating 
system.

MONITORING: Northern States Power will provide instrumentation. Fourchannel magnetic tape to record time, furnace, and total loads at 15-minute intervals. Monitoring to continue as Northern States Power-Wisconsin implements its residential TOD rate.

INTERV IEW

DATE:

May 6, 1980.

STATUS: $\quad$ Furnace installed in 1978. Monitoring installation not completed in time for 1978-79 heating season. Data was collected in 1979-80 and will be collected in 1980-81 heating season.

RESULTS: $\quad 30-\mathrm{kW}$ unit exceeds heating requirements for the home. Two of the 11 heating elements have been disconnected leaving $24 \mathrm{~kW}$ of storage capability. Test results also indicate that the night-heating $15-\mathrm{kW}$ electric furnace could be reduced to $5 \mathrm{~kW}$.

$\begin{array}{ccc}\frac{\text { Year }}{1979-80} & \text { kWh Consumption } & \text { Heating Degree Days } \\ 1978-79 & 15,888 & 7,073 \\ 18,048 & 7,887\end{array}$

At the present time the owner has not received any special rate from Northern States Power for off-peak heating. As Northern States Power's TOD rate is implemented, home owner plans to shift additional energy usage to off-peak periods. Northern States Power's monitoring system will monitor this price-induced shift. 
IOWA ELECTRIC LIGHT \& POWER COMPANY

200 First Street, SE

Cedar Rapids, Iowa 52401

NEW 1980

(319) 398-4411

Bob Close, Manager of Marketing

SYSTEM: $\quad$ Ceramic Heat Storage - Central Residential

SUMMARY: $\quad$ Iowa Electric Light \& Power Company has initiated a pilot demonstration program of residential storage heating. The objectives of the program are to determine customer accoptance and the economics of the central ceramic heat storage concept. Efforts are underway to recruit 22 customers in whose homes the units will be installed. Iowa Electric Light \& Power Company will partially subsidize the purchase of the hardware and will pay for its installation. At the end of two years, the customer will have the option of either keeping the hardware and paying $50 \%$ of the original installation charges or returning the hardware for a full refund of the customer's original $\$ 1150$ purchase price.

EQUIPMENT: TPI 21-kW ceramic storage furnaces. Actual sizes may vary, depending upon individual requirements.

CONTROL: $\quad$ Time switch incorporated into time-of-day meter.

SAMPLE: $\quad$ Twenty-two residential customers.

INCENTIVE: Time-of-day rates. Off-peak rate (8:00 p.m. - 7:00 a.m.) $50 \%$ of base rate. On-peak rate $125 \%$ of base rate.

MONITORING: Kilowatthour meters on storage and night heating sections. Complete instrumentation plans not yet finalized. 
$1-43$

INTERVIEW

DATE:

December 2, 1980

STATUS:

Customer recruitment underway.

RESULTS:

Not yet determined. 
PACIFIC GAS AND ELECTRIC COMPANY

REV ISED 1980

77 Beale Street

San Francisco, California 94106

(415) $781-4211$

John S. Cooper, Vice President, Customer Operations

SYSTEM: $\quad$ High Temperature Ceramic Heat Storage - Central Residential

SUMMARY: $\quad$ Pacific Gas and Electric is conducting a residential test of a central electric furnace equipped with a ceramic thermal storage unit. Off-peak electric water heating is included in the study.

EQUIPMENI: TPI $30-\mathrm{kW}$ ceramlc heallistorage unit capable of storing 200 $\mathrm{kWh}$ of thermal energy. Standard 14-kW electric furnace. A very well insulated A.0. Smith 82-gallon water heater.

CONTROL: Time switch permits furnace thermal element to recharge during off-peak hours only. The water heater is similarly controlled and has a special manual switch for on-peak emergency hot water.

TEST

ENVIRONMENT: All-electric specification-type residence in Quincy, California. Heavily insulated, windows double-glazed, 6,000 degree-days.

SAMPLE: $\quad$ One house.

INCENTIVE: $\quad \$ 20$ per month reimbursement for anticipated system losses and inconvenience.

MONITORING: $\quad$ kWh meter on main house service. kWh meter on heat storage unit, furnace, and water heater combined. Magnetic tape recorder on furnace, storage unit, and water heater override separately. Plan additional monitoring of air 
temperatures.

INTERV IEW

DATE:

STATUS:

RESULTS :
September 17, 1980.

System in full operation. Started January 1978.

Indoor comfort has been excellent. kWh use has been high to date. Because of some variables in the family's living habits, they are presently planning to continue data acquisition through winter of 1980-81. 
PUBLIC SERVICE ELECTRIC AND GAS COMPANY

80 Park Place

Newark, New Jersey 07101

Fred Thurkauf, Jr., Manager, Load Management

Clark W. Gellings, Assistant Manager, Load Management

SYSTEM: $\quad$ Ceramic Heat Storage - Central Residential

SUMMARY: $\quad$ Public Service Electric and Gas Company has entered into a contract with the Oak Ridge National Laboratory for a demonstration of electric load management by controlled customer-side energy storage sponsored by the department of Energy. The project consists of retrofitting 30 single family homes utilizing conventional electric furnaces with a central electric ceramic brick storage heat furnace. The conventional water heater in these test homes will also be replaced with a storage type unit. A unique feature of this test is the use of a communications system to place the installed storage equipment under utility control. It is anticipated that conventional off-peak operation, as well as economic dispatch of generation schedules, will be tested. A control group consisting of 30 conventional allelectric houses will also be instrumented. The project. will commence prior to the 1979-80 heating season and data will be collected for a total of two years.

EQUIPMENT: TPI central ceramic storage furnaces. A. 0. Smith water heaters. DARCOM, Inc. communications system.

CONTROL: The test and control homes' interior temperatures will be controlled by a day/night thermostat supplied as part of the equipment. Storage furnace charging and water heating at the test location will be controlled by PSE\&G over voiccgrade telephone lines utilizing a DARCOM communications system. Communications reliability is assured by the use 
of dual modems and back-up telephone 1 ines for the master controller. In addition, the test customers have a manual override to activate a conventional resistance furnace integral with the storage furnace.

SAMPLE: $\quad 30$ single-family homes and a control group of 30 additional single-family homes.

INCENTIVE: Control customers receive a day/night thermostat and $\$ 10$ per month. Test customers received time-of-use rates.

MONITORING: The following environmental variables are to be metered at 15-minute intervals utilizing magnetic tape recording meters. Test Group - A11: Electric energy to base loads including air conditioning, electric energy to auxiliary furnace in storage furnace, electric energy to storage furnace excluding auxiliary furnace energy, electric energy to water heater, inside air temperature, water flow (hot). Test Group - Five Only: Core temperature of thermal storage unit, air flow of thermal storage unit, air flow $\Delta T$ of thermal storage unit.

Control Group - All: Electric energy to base loads including air conditioning, electric energy to conventional furnace, electric energy to water heater, inside air temperature, water flow (hot).

Control Group - 15 relative humidity only. 15 hot water heater energy - Btu's only.

INTERV IEW

DATE:

August 10, 1979

STATUS: Installation is underway.

RESULTS: $\quad$ Not yet determined. 
UNITED POWER ASSOCIATION

REVISED 1980

Elk River, Minnesota 55362

Vance Zehringer, Supervisor, Load Management

(612) $441-3121$

SYSTEM: $\quad$ Ceramic Heat Storage - Residential

SUMMARY: $\quad$ TPI ceramic heat storage systems will be installed in a combination of 35 new and retrofit homes in Anoka Electric Cooperative and Wright-Hennepin Cooperative Flectric. Assoriation servire areas. A 35-home control group with electric warm air furnaces will also be monitored. Load research data will be gathered in all 70 homes, and five homes will be instrumented for additional device-specific data. Off-peak control will be by radio.

EQUIPMENT: TPI 30-kW ceramic heat storage systems. Scientific Atlanta radio control system. 120-gallon A. 0. Smith conservationist water heater.

CONTROL: $\quad$ Radio from United Power Association's Elk River Energy Center.

TEST

ENVIRONMENT: Combination of new and retrofit houses. Most are wel1insulated. 8,500 heating degree-days. Design temperature- minus $25^{\circ} \mathrm{F}$.

SAMPLE: $\quad 35$ new and retrofit homes, and 35 new and existing homes in a control group.

INCENTIVE: $\quad \$ 37.50$ per quarter for eight quarters. $\$ 700$ in escrow. 
MONITORING: Monitoring in 35 homes: total energy, storage system energy, water heater energy, gallons of water, and room temperature. Monitoring in five homes also includes $\Delta T$ furnace air, air flow in $\mathrm{cfm}$, core temperature, skin temperature, outdoor temperature, $\Delta T$ water temperature, wind and solar intensity.

INTERV IEW

DATE:

May 5, 1980.

STATUS:

All installations completed. Monitoring continuing.

RESULTS:

Not yet determined.

REMARKS: $\quad$ This is a Department of Energy/Oak Ridge National Laboratory funded project. 


\subsection{PRESSURIZED WATER HEAT STORAGE}

\section{Technical Characteristics}

This thermal storage system was designed originally to provide offpeak domestic hot water in multi-family buildings. More recently, its use has been extended to commercial and residential off-peak space heating. Its design utilizes an insulated cylindrical steel tank in which treated water is heated by electric immersion heaters to temperatures of up to $280^{\circ} \mathrm{F}\left(138^{\circ} \mathrm{C}\right)$ at pressures of up to $50 \mathrm{psig}$ $\left(3.5 \mathrm{~kg} / \mathrm{cm}^{2}\right)$. This pressurized tank unit replaces the conventional boiler or furnace and may be used with various distribution methods, including hydronic baseboard radiation and warm air ducts.

Commercial units are designed and built specifically for each individual application, based on heating capacity requirements and available off-peak charging hours. One of the largest installations is in a Manchester; New Hampshire hospital where eleven 11,000-gallon (41,639liter) units provide off-peak storage for space and water heating. The New Hampshire Insurance Company building has three 16,000-gallon (60,567-1iter) units rated at $736 \mathrm{~kW}$ each, designed for eleven hours of off-peak charging. Other commercial units have been built in sizes from 350 to 20,000 gallons ( 1325 to 75,708 liters) with diameters from 36 inches $(91.4 \mathrm{~cm})$ to $10-1 / 2$ feet $(3.2$ meters $)$.

A standardized residential unit that holds 246 gallons (931 liters) of water is rated at $30 \mathrm{~kW}$. Its overall dimensions are $40-i n c h(102-\mathrm{cm})$ height, 38-inch $(96.5-\mathrm{cm})$ width, and $104-$ inch $(264-\mathrm{cm})$ length, including the control panel. Weight is 1100 pounds $(499 \mathrm{~kg})$ without water. By disconnecting lead wiring, the rating can be reduced to 24,18 , or $12 \mathrm{~kW}$. On start-up, the heating elements are staged in $6-\mathrm{kW}$ increments. This complete package unit includes a steel tank, 240-volt electric elements, heat exchanger, water inlet and outlet ports, balancing- 
heating chamber, temperature safety control, pressure control, relief valve, and drain valve. The tank is charged with treated water to prevent corrosion, scale, and element burn-outs.

\section{System Costs and Payback}

The current wholesale price of the standard residential unit is $\$ 2300$. If the unit is to be used with a forced air distribution system, it is necessary to add $\$ 250$ to the wholesale price for a duct coil heat exchanger. This system, at an assumed installed cost of $\$ 3300$, will be compared to the central electric furnace described in the previous section.

The $\triangle I C$ for this TES system, based on a $\$ 400$ installed cost for the electric furnace, is $\$ 2900$. The annual cost savings are

$$
\triangle A O P C=\triangle R \times 910
$$

and the payback period is

$$
n=\frac{2900}{\Delta R \times 8910}
$$

Payback periods produced by incremental rate reductions are shown in Table 1-9.

Table 1-9

PAYBACK PERIOD DERIVED FOR A GIVEN $\triangle R$ PRESSURIZED WATER HEAT STORAGF

$\Delta R(\$ / k W h)$

.02

$\underline{n}$ (years)

.04

16.3

.06

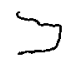

.08

8.1

5.4

4.1 
Pressurized Water Heat Storage

Equipment Manufacturer

\author{
Megatherm \\ 803 Taunton Avenue \\ East Providence, Rhode Island
}


Table $1-10$

Pressurized Mater Heat Storage - Residential Projects Sunwary

\begin{tabular}{|c|c|c|c|c|c|c|c|c|c|}
\hline \multirow{2}{*}{$\underset{\text { Eastern Utili ity Associates }}{\underline{U t \text { tility }}}$} & Contact & \multirow{2}{*}{$\begin{array}{c}\text { Equipenent } \\
\text { Megat herm }\end{array}$} & $\underline{\text { Control }}$ & Sample & \multicolumn{2}{|r|}{ Monitoring } & \multicolumn{2}{|r|}{ Results/Remarks } & \multirow{2}{*}{$\begin{array}{l}\text { Contact Date } \\
\text { July } 11,1980\end{array}$} \\
\hline & $\begin{array}{l}\text { Gordon Jeard, Director, Consumer } \\
\text { Services } \\
(617) \text { S50-1213 }\end{array}$ & & Time switch & 6 houses & 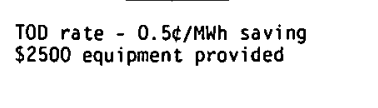 & $\begin{array}{l}\text { Magnetic tape on } 4 \text { hames plus } \\
\text { ERPA non titoring on } 2 \text { nomes } \\
\text { completed }\end{array}$ & Test continuing & $\begin{array}{l}\text { Comfort excellent. EPRI data } \\
\text { analysis pending. }\end{array}$ & \\
\hline $\begin{array}{l}\text { Green Mounta in Power } \\
\text { Corporation }\end{array}$ & $\begin{array}{l}\text { Henry A. Boisse, Director of Marketing } \\
\text { (802) } 864-5731\end{array}$ & Mega therm & Time switch & 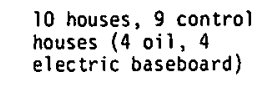 & TO0 rate & $\begin{array}{l}\text { Magnetic tape on } 14 \text { points. } \\
\text { university of tevernont and } \\
\text { Argonne assisting. }\end{array}$ & Test continuing & $\begin{array}{l}\text { l975 and } 1977 \text { reports issued. } \\
\text { Final report availiable. }\end{array}$ & April 29, 1980 \\
\hline Long Island Lighting Company & $\begin{array}{l}\text { Robert E. Asshurn, Manager, Economic } \\
\text { Research } \\
(516) \text { 228-2195 }\end{array}$ & Megatherm & Radio & $\begin{array}{l}50 \text { houses } \\
35 \text { control houses }\end{array}$ & 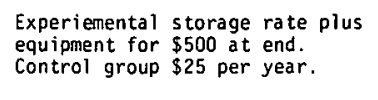 & $\begin{array}{l}\text { Magnetic tope on energy use } \\
\text { and air and water temperature }\end{array}$ & System installed & $\begin{array}{l}\text { Not yet determined. } \\
\text { DoE/ORNL project. }\end{array}$ & April 29, 1980 \\
\hline $\begin{array}{l}\text { Pennsylvania Electric } \\
\text { Conpany }\end{array}$ & $\begin{array}{l}\text { Timothy R. Nunfer, Director, Technical } \\
\text { SServices } \\
\text { (814) } 536-6611\end{array}$ & Megatherm & Time switch & $\begin{array}{l}1 \text { house } \\
\text { i control house }\end{array}$ & $\begin{array}{l}\text { Tod rate }-1.06 \text { to } 1.96 / \mathrm{kkhh} \\
\text { saving }\end{array}$ & $\begin{array}{l}\text { Magnetic tape on energy use } \\
\text { and temperature }\end{array}$ & completed & $\begin{array}{l}5 \times 4 \text { to } 9 \mathrm{kw} \text { on-peak load reduc- } \\
\text { tion. Radio control successsful. } \\
\text { Finai report July } 1980 .\end{array}$ & April 25, 1980 \\
\hline The Potomac Edison Company & 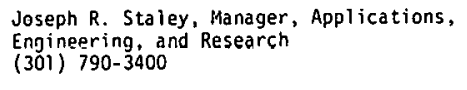 & Mega therm & Time switch & 1 house & Nonte" & $\begin{array}{l}\text { Magnetic tape on energy us } \\
\text { plus EPRI monitoring }\end{array}$ & Test continulu ing & 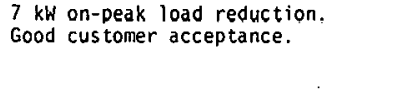 & May 22, 1979 \\
\hline $\begin{array}{l}\text { Publ ic Service Company of } \\
\text { New Hampshire }\end{array}$ & 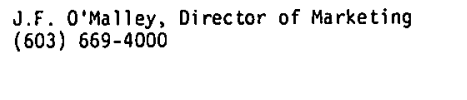 & Mega therm & Time switch & 20 houses & $\begin{array}{l}\text { Experimental To0 rate and } \\
\text { partial equipent funding. }\end{array}$ & $\begin{array}{l}\text { Magnetic tape on energy use } \\
\text { and temperature }\end{array}$ & $\begin{array}{l}\text { Test } \\
\text { termina ted }\end{array}$ & 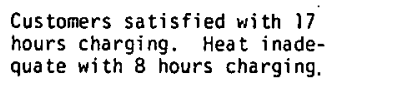 & July 9, 1980 \\
\hline \multicolumn{10}{|c|}{ Table $1-11$} \\
\hline \multicolumn{10}{|c|}{ Pressurized Hater Heat Storage - Commer ical Projects Summary } \\
\hline Utility & contact & Equipment & $\underline{\text { Control }}$ & Sample & $\underline{\text { Incentive }}$ & Monitoring & $\underline{\text { status }}$ & Results/Remarks & Contact date \\
\hline Duke Pöwer Company & $\begin{array}{l}\text { Ennest C. Dowless, Manager, Cormercial } \\
\text { PPover } \\
(700) \text { 373-4304 }\end{array}$ & 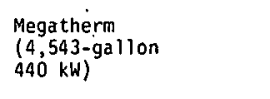 & Time switch & $\begin{array}{l}\begin{array}{l}44,000 \text { sq. } \\
\text { high school }\end{array} \\
\text { ft. }\end{array}$ & Reduced demand charge & $\begin{array}{l}\text { Magnetic tape on demand } \\
\text { and energy use }\end{array}$ & Test continuing & $\begin{array}{l}\text { uinter peak demand moved to } \\
8 \text { p.m. and } 70 \text { kt less. }\end{array}$ & April 30, 1980 \\
\hline Gulf Power Company & $\begin{array}{l}\text { John D. Searer, Director, Market ing } \\
(2004) \text { 434-82894 }\end{array}$ & 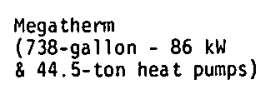 & Time switch & $\begin{array}{l}\text { 20,000 sq. ft. } \\
\text { office building }\end{array}$ & Reduced demand charge & $\begin{array}{l}\text { Submetering of Mega therm } \\
\text { and heat punps . }\end{array}$ & $\begin{array}{l}\text { Test continuing } \\
\text { (occupied Aug. } \\
\text { i, 1978) }\end{array}$ & $\begin{array}{l}\text { Not yet determined. Extra cost } \\
\text { \$333, } \\
\text { s17,000 Extrimated savings }\end{array}$ & August 7, 1978 \\
\hline $\begin{array}{l}\text { Public Service Company } \\
\text { of New Hampshire }\end{array}$ & 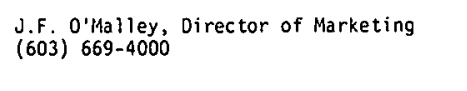 & 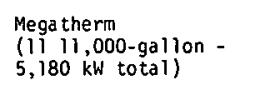 & Time switch & $\begin{array}{l}\text { 258-bed, } 250,000 \\
\text { ss. ft. hospital } \\
\text { complex }\end{array}$ & Too rate & Metering and submetering & $\begin{array}{l}\text { Data collection } \\
\text { and analysyis } \\
\text { continuing }\end{array}$ & Dperation successful. & April 30, 1980 \\
\hline
\end{tabular}


THIS PAGE

WAS INTENTIONALLY

LEFT BLANK 
DUKE POWER COMPANY

REV ISED 1980

422 South Church Street

Charlotte, North Carolina 28242

(704) $373-4304$

Ernest C. Dowless, Manager, Commercial Power

SYSTEM: $\quad$ Pressurized Water Heat Storage - Commercial

SUMMARY: This system includes a 4,543-gallon Megatherm heat storage system that was selected for installation in a new 44,000square-foot junior high school building. The principal objective, to reduce the school's daytime winter peak, has been achieved. Efforts are continuing to reduce electrical demand during unoccupied hours in winter. Reduction of water temperature is being considered as a means of lowering $\mathrm{kW}$ demand. Monitoring of the system is continuing. If the system proves effective, the School Board is interested in making similar installations in other school buildings.

EQUIPMENT: Megatherm pressurized water heat storage system with 4,543-gallon, 440-kW tank. Storage temperature is $250^{\circ} \mathrm{F}$ to $280^{\circ} \mathrm{F}$ at $50 \mathrm{psi}$.

CONTROL: $\quad$ Time switch for off-peak charging between $3 \mathrm{p} . \mathrm{m}$. and 7:30 a.m. Temperature cut-off at $245^{\circ} \mathrm{F}$ and cut-in at $180^{\circ} \mathrm{F}$.

TEST

ENVIRONMENT: New, 44,000-square-foot junior high school, single story with basement. Degree-days--3,300. Design temperature-$10^{\circ} \mathrm{F}$.

SAMPLE: $\quad$ Single installation near. Hickory, North Carolina.

INCENTIVE: No rate incentive. Reduced demand potential. 
MONITORING: DSL magnetic tape recorders. Data collection includes total energy use, kWh and demand; heating system and storage system use, kWh and demand; and food service energy use, kWh and demand.

INTERV IEW

DATE:

STATUS:

RESULTS:
Apri1 30, 1980.

In service.

The control system has been balanced and the school is operating very satisfactorily. The winter peak demand in 1970 oceurred at noon. Control modifications caused the noon demand on the peak 1979 winter day to be approximately $130 \mathrm{~kW}$ less than in 1978. The building winter peak demand was moved to 8 p.m. and was still $70 \mathrm{~kW}$ less than the 1978 peak demand.

The system has maintained the comfort level in the building without utilizing the full kW of the Megatherm. To date, $120 \mathrm{~kW}$ of lhe Megatherm heating elements havc bcen disconnected. This has lowered off-peak demand while still adequately charqing the Megatherm for the following day's usage. 
EASTERN UTILITIES ASSOCIATES

36 Main Street

Brockton, Massachusetts 02403

Gordon Jezard, Director, Consumer Services

SYSTEM: $\quad$ Pressurized Water Heat Storage - Residential

SUMMARY: $\quad$ Eastern Utilities Associates is sponsoring a project among its three member companies involving the evaluation of the load shifting capabilities of the Megatherm storage system. Eastern Utilities Associates is offering a total of six Megatherm units, two to each of its member companies. To date, three units have been installed, including the Megatherm system and an 80-gallon water heater. Monitoring of the systems began winter 1978-79.

EQUIPMENT: 210-gallon Megatherm units with 80-gallon water heaters.

CONTROL: $\quad$ Time switch for charging off-peak.

TEST

ENV IRONMENT: Six units in new homes (four employees' homes) sized in the 2,000-square-foot class. Design temperature-- $0^{\circ} \mathrm{F}$. Degree-days--6,000. Eastern Utilities Associates is winter peaking.

SAMPLE: $\quad$ Six residences.

INCENTIVE: Eastern Utilities Associates is providing the Megatherm units and the water heaters free of charge to the program participants. Megatherm units and water heaters will be submetered and will be eligible for a special rate, approximately $0.5 \$ / \mathrm{kWh}$ lower than the regular residential rate. Customer keeps equipment worth $\$ 2,500$.

MONITORING: A.D. Little for EPRI is monitoring two installations. 
Monitoring will include total weather data; energy consumption rates of whole house, Megatherm, and water heater; water temperatures for water heater; and pressures for Megatherms. All recorded on magnetic tape meters.

INTERV IEW

DATE:

JuTy $11,1980$.

STATUS: $\quad$ Six units have been installed. Instrumentation was by A.D. Little for EPRI on two homes. Eastern Utilities Assocyates mag tapes on four hornes.

RESULTS: Residents report good comfort level. EPRI data analysis pending. 
GREEN MOUNTAIN POWER CORPORATION

REV ISED 1980

1 Main Street

Burlington, Vermont 05401

(802) 864-5731

Henry Boise, Director of Marketing

SYSTEM: $\quad$ Pressurized Water Heat Storage - Residential

SUMMARY: Residential central heating is provided by resistanceheated pressurized water heat storage systems in this ten-installation demonstration project which is partially sponsored by FEA. The test will provide data for comparison with electric baseboard and oil-fired heating, as well as system costs.

EQUIPMENT: $\quad$ Megatherm pressurized storage heating systems - $14 \mathrm{~kW}$.

CONTROL: $\quad$ Time switches.

TEST
ENVIRONMENT: Houses selected for project are approximately $900-\mathrm{ft}^{2}$ "wonder homes" insulated to NEMA standards: walls-4-inch, ceilings--6-inch, basement--3-inch. Degree-days-8,500. Design temperature-minus $20^{\circ} \mathrm{F}$.

SAMPLE: Ten experimental homes. Control units: four oil heat; four baseboard. Comparative data wiīi be collected.

INCENTIVE: Time-of-day optional rates.

MONITORING: Five homes are fully instrumented with 14 monitoring points each. University of Vermont is assisting with monitoring in conjunction with Argonne National Laboratory.

INTERV IEW

DATE: April 29, 1980. 
STATUS: In service.

RESULTS: A final report on the project in now available. Preliminary reports in September 1975 and June 1977 have been issued.

REMARKS: A 3,000-gallon Megatherm pressurized water heat storage unit was installed in a new Green Mountain Power building for service personnel, with high temperature ceramic room storage in the individual offices. The ceramic units are sized to provide a $55^{\circ} \mathrm{F}$ base and the remaining heating is provided by forced air using the heat stored in the Megatherm. The 30,000-square-foot structure was opened in August 1977. 
LONG ISLAND LIGHTING COMPANY

REV ISED 1980

250 0ld Country Road

Mineola, New York 11501

(516) 228-2195

Robert E. Ashburn, Manager, Economic Research Department

John J. Kinirons, Manager, Load Research \& Load Management Division

SYSTEM: $\quad$ Pressurized Water Heat Storage - Residential

SUMMARY: Long Island Lighting Company, in conjunction with the Department of Energy and the Empire State Electric Energy Research Corporation, is participating in a national energy storage demonstration program that will involve the installation of 50 residential electric heat storage systems. During operation, water is to be heated in off-peak hours and circulated when the house thermostat calls for heating. The test will measure the effective energy displacement from peak periods to off-peak periods. The participating customers will be billed for the energy consumed by the system, under the provisions of a special experimental storage rate specifically established for this program. Customers are further guaranteed that the cost of operation will not exceed normal heating costs adjusted for current prices and degree days. Billing will be based on this storage rate for energy used between midnight and $7 \mathrm{a} . \mathrm{m}$. , and at the residential general service rate for all other hours in which the system uses energy. In addition to the 50 test homes, 35 homes having electric space heating will be selected to serve as the control group. The test is scheduled for two heating seasons.

EQUIPMENT: A model RH30 Residential Thermal Storage System manufactured by Megatherm Corporation, is to be installed in each test home. This system replaces the oil-fired hot water boiler used for heating those homes. The heart of the system is a sealed tank filled with 245 gallons of water. 
Electric resistance heaters, built into the tank, heat the water to $290^{\circ} \mathrm{F}$ using low cost, off-peak electric power. The tank is fitted with a pressure relief valve, factory-set to open at $60 \mathrm{psi}$, to assure the utmost in safety during operation. A separate 82-gallon electric water heater supplies domestic hot water.

CONTROL: To remotely control the heat storage systems, a Scientific Atlanta radio receiver is being installed above the electric meter at each test home. Periodically, Long Island Lighting Company will implement various control strategies by altering the time periods in which the heat storage system is allowed to charge or reslore ils hedliny capacity. The objective here is to determine optimurn control strategies that provide both adequate charging time and keep the storage system from charging during the utility's peak period.

TEST

ENVIRONMENT: Single families having an average of 1,800 to 2,000 square feet of living space. There are two to six persons per family.

SAMPI F: $\quad-50$ homes of various architectural designs. each presently equipped with an oil-fired hydronic heating system.

INCENTIVE: Experimental storage rate. Option to purchase storage system for $\$ 500$ at end of project. Control group customers will receive a $\$ 25$ check at the conclusion of each heating season.

MONITORING: The following data is to be collected at the 50 homes equipped with the storage system: total load to home,. load to storage, indoor ambient temperatures, inlet water temperature, outlet water temperature, water flow. 
The following data is to be collected at the 35 homes equipped with electric space heating: space heating load, total house load, indoor and outdoor ambient temperatures.

INTERVIEW

DATE:

STATUS:

RESULTS:
April 29, 1980.

Five systems have been installed to date. The installation costs associated with these initial installations are being reviewed and a change of specifications is being considered.

Not yet deterinined. 
PUBL IC SERVICE COMPANY OF NEW HAMPSHIRE 1000 Elm Street

P.0. Box 330

Manchester, New Hampshire 03105

REV ISED 1980

(603) $669-4000$

J. F. O'Malley, Director of Marketing

SYSTEM: $\quad$ Pressurized Water Heat Storage - Commercial

SUMMARY: In what is believed to be the largest installation of its kind to date, a pressurized water heat storage system has been completed in a 268-bed, 250,000-square-foot hospital complex. I he system, which satisfied bulh space and water heating requirements, stores heat off peak in eleven pressurized water storage tanks of 11,000 gallons capacity each. Total power demand for charging is $5,180 \mathrm{~kW}$. Benefits, compared with a conventional system, include reduced operating costs, cleanliness of operation, improved reliability, and the elimination of the boiler house and its attendant hazards. The installation of the system was rompleted in 1979, and it has been operating successfully since.

EQUIPMENT: The storage system includes eleven Megatherm tanks of 11,000-gal1on capacity each. Eight tanks provide space heating, two provide water heating, and one is a spare. Power demand for charging the tanks ranges from 290 to $680 \mathrm{~kW}$ for a total of $5,180 \mathrm{~kW}$. A breakdown of power demand shows four tanks for the 70,000 square feet of existing space at $300 \mathrm{~kW}$ each, four tanks for the 180,000 square feet of new space at $680 \mathrm{~kW}$ each, two domestic water tanks at $290 \mathrm{~kW}$ each, and one spare heating tank at $680 \mathrm{~kW}$. This power is consumed as 
needed by the resistance heating elements during the 8 p.m. to 7 a.m. off-peak hours. Heated water is stored in the sealed tanks with a heat exchanger used to transfer stored energy to the building's system.

CONTROL: $\quad$ Time switch limits charging to off-peak hours of 8 p.m. to 7 a.m.

TEST

ENVIRONMENT: Installation is in the Catholic Medical Center, Manchester, New Hampshire, which is a 268-bed, 250,000- $\mathrm{ft}^{2}$ hospital complex. Estimated annual heat loss is 38.2 billion Btu with a maximum rate during winter months of 15 million Btu per hour. Perimeter walls are insulated for an average "U" factor of 0.06 . Al1 windows are double-glazed and recessed in patients' rooms. A heat wheel is installed in the kitchen air exhaust to utilize heat that would otherwise be lost.

SAMPLE: $\quad$ Single installation. Believed to be the largest of its type.

INCENTIVE: Off-peak rates.

MONITORING: Metering and submetering.

INTERVIEW

DATE:

April 30, 1980.

STATUS: Completely installed. Data collection continuing.

RESULTS: Installation completed and the system is operating successfully. 
REMARKS: $\quad$ Considerable economy of space has been achieved by locating the Megatherm system under a parking area. 
PUBLIC SERVICE COMPANY OF NEW HAMPSHIRE

REVISED 1980

1000 EIm Street

P.0. Box 330

Manchester, New Hampshire 03105

(603) $669-4000$

J.F. O'Malley, Director of Marketing

SYSTEM: $\quad$ Pressurized Water Heat Storage - Residential

SUMMARY: A 20-home demonstration project was sponsored by the Public Service Company of New Hampshire with the selection of homes controlled to provide a representative cross section of residential customers. An 80-gallon water heater was installed in conjunction with the pressurized water heat storage unit. Both the efficiency and economics of the off-peak system was assessed, as well as load shifting potential. Project was terminated and report is in preparation.

EQUIPMENT: A 210-ga11on, 50-psi, pressurized Megatherm storage unit was installed in each test home, along with an 80-gallon Vaughn water heater. Both devices draw power from their resistance heating elements during off-peak hours, except that the water heater has a 3,000-watt uncontrolled upper element to guarantee adequate supply.

The Megatherm is a closed, system that exchanges heat with the working fluid of the residential heating system which, in this case, is hydronic. It is charged by four staged resistance heating elements of $7 \mathrm{~kW}$ each. The number of operational heating elements and, hence, the charging rate is determined by the outside temperature in anticipation of the next day's heating load.

CONTROL: $\quad$ Time switch limiting charging to off-peak only. 
TEST

ENVIRONMENT: Test customers were selected from survey results to provide a representative cross section of family characteristics, life styles, etc. Homes vary from about 1,600 square feet to 2,400 square feet and have a heat loss of less than 10 watts per square foot. Insulation characteristics are R-24 and R-19, with R-11 inside walls. Degree-days- $-7,200$ to 8,900 . Design temperature--minus $15^{\circ} \mathrm{F}$ to minus $20^{\circ} \mathrm{F}$.

SAMPLE: Twenty houses. Nineteen were in operation in the winter of 1976-77. Data was collected for the winter of 197\%-78 and continued to necember 31, 1979.

INCENTIVE. [xperimental off-pcak rates. Partial funding by the utility.

MONITORING: Recording meters monitor the Megatherm and water heater energy use, as well as all other encrgy use in the test homes. Outdoor temperature and storage temperature are also monitored.

INTERVIEW

DNTE:

July $9,1980$.

STATIIS: $\quad$ Project terminated. Report being prepared.

RESULTS: $\quad$ Nineteen units have been operational since the winter of 1978-79. Essentially no maintenance has been required and customers are satisfied with the operdtion. Results were excellent when 17 hours of charging were allotted, including two daytime periods. When charying time is reduced to eight hours, heating is inadequate. 


\subsection{IN-GROUND HEAT STORAGE}

\section{Technical Characteristics}

The ground beneath a building offers a large, conveniently located, thermal reservoir. One manufacturer is marketing an in-ground heat storage system consisting of preformed mats of electric resistance cable installed 12 inches $(30 \mathrm{~cm})$ below a 6 -inch $(15-\mathrm{cm})$ concrete floor slab on a bed of well-compacted sand or clean fill. The resulting 18-inch $(45-\mathrm{cm})$ spacing below the floor surface has been found by tests to be the optimum level to produce an even floor temperature over a sustained on-peak period with the mats turned off. Between $65 \%$ and $70 \%$ of the heat in this combination ground and slab reservoir is radiated and $30 \%$ to $35 \%$ is convected, resulting in little or no heat stratification in the building. Tests in a number of installations indicated temperatures of $73^{\circ} \mathrm{F}\left(22.8^{\circ} \mathrm{C}\right)$ at the ceiling and $72^{\circ} \mathrm{F}\left(22^{\circ} \mathrm{C}\right)$ one foot $(30 \mathrm{~cm}$ ) above the floor. Approximately $75 \%$ of the heat input to the mats is conducted upward and the balance downward until it reaches the $50-55^{\circ} \mathrm{F}\left(10-13^{\circ} \mathrm{C}\right)$ ground temperature level at about five feet $(1.5$ meters) below grade. It has been found that the ground reservoir stays intact over the summer months ready to start the heating season in the fall with only an approximate $2^{\circ} \mathrm{F}\left(1^{\circ} \mathrm{C}\right)$ drop one foot $(30 \mathrm{~cm})$ below and a $3^{\circ} \mathrm{F}\left(1.6^{\circ} \mathrm{C}\right)$ drop five feet $(1.5$ meters) below the slab. As the effective heat spread is seven feet $(2.1$ meters), the 36 -inch $(91-\mathrm{cm})$ wide mats can be placed 36 inches $(91 \mathrm{~cm})$ apart without any cold spots developing on the floor surface. Due to the thermal inertia of the heat reservoir, off-peak charging is highly successful and little building temperature drop occurs even with a power outage of several hours.

Building insulation to reduce heat loss to 10 watts per square foot (108 watts per square meter) or less at design temperature is essential. In buildings where forced air exhausts are operated or shipping doors are opened frequently, supplemental local heat units are required. 
To protect against lateral heat loss below the slab, two inches $(5 \mathrm{~cm})$ of rigid foam insulation is required on the inner surface of the building foundation to a depth of four feet $(1.2 \mathrm{~m})$. If the foundation wall is exposed, four inches $(10 \mathrm{~cm})$ of insulation should be used. A plastic vapor barrier is installed in the sand below the slab.

In this system the floor temperature cannot be changed quickly to accommodate short-term changes in heat load. When operating on an offpeak schedule, the opportunity to change floor temperature occurs only during the off-peak period. In the event of a sudden substantial fncrease in outdoor tcmpcrature, some heat rise will be noticeable in the building.

The heating cable in the mats consists of a glass fiber core wrapped with nichrome wire covered with $221^{\circ} \mathrm{F}\left(105^{\circ} \mathrm{C}\right)$ PVC inner insulation and a nylon outer jacket, which is, in turn. wrapped with braided copper ground wire. In normal operation, the cable operates at $105^{\circ} \mathrm{F}\left(40.5^{\circ} \mathrm{C}\right)$. A high temperature safety cutout, factory-set at $130^{\circ} \mathrm{F}\left(54.4^{\circ} \mathrm{C}\right)$, is taped to the center cable of the mat. A thermostat sensing bulb in a conduit in the slab restricts slab temperature to the appropriate level or a maximum of $85^{\circ} \mathrm{F}\left(29.4^{\circ} \mathrm{C}\right)$. The floor slab may be covered with asphalt tile, linoleum, ceramics, or other dense material, but not carpet, wood, or other substances that provide poor heat transfer.

Mats are available for service voltages from 208 to 480 and in lengths from 5.5 to 64 feet $(1.7$ to $19.5 \mathrm{~m})$.

In most residences with time-of-day rates, these installations are controlled by a time switch, but in larger buildings they are usually equipped with an automatic control to advance or retard slab temperature according to outdoor temperature and to limit charging to periods of low demand.

In commercial and industrial applications, the economics of this system is based on reducing monthly or annual demand charges, while in residential applications an incentive rate is essential. 
This type of system was originally developed for one-story commercial and industrial structures; however, in Wisconsin, North Dakota, and Minnesota this sytem has been installed in several hundred houses, most of which have basements. Supplemental electric resistance heating or a second TES system is required in these houses.

System Costs and Payback

The manufacturer of this system provided the following installed cost information: for industrial applications in buildings of 10,000 square feet (929 square meters) or larger, current installed costs average $\$ 1.10$ per square foot (\$11.84 per square meter). For light commercial and residential applications, installed costs average $\$ .60$ to $\$ .65$ per square foot ( $\$ 6.46$ to $\$ 7.00$ per square meter).

As mentioned previously, the major residential application of this system involves its use as a supplement to either a conventional heating system or another type of TES system. It is conceivable that an inground heating system could be installed in a single-story slab-based house (similar to the house used as an example thus far).

An in-ground heating system cannot respond rapidly to changing heating requirements and its use precludes certain floor coverings (carpets, wood, etc.). It is unlikely, therefore, that a homeowner would, for aesthetic and comfort considerations, use such a system as his only means of space heating. It will be assumed that the house in this example will be equipped with only a partial in-ground system (50\%) and the remaining heating requirements will be supplied by a reduced size baseboard heating system. The cost comparison will be made between this mix of systems and a conventional baseboard system. Based on the manufacturer's estimate of $\$ .65$ per square foot $(\$ 7.00$ per square meter) installed, a 50\% in-ground system for the 1100-squarefoot (101.2-square-meter) house would cost about $\$ 360$. The supplemental baseboard system is assumed to cost $\$ 510$. The $\triangle I C$ of this system, using the baseboard system cost developed in Section 1.1, would be $\$ 360$. Assuming that the in-ground system 
provides $50 \%$ of the heating requirements, the annual operating cost savings are

$$
\triangle A O P C=\triangle R \times 8580 \times .5
$$

and the payback period is

$$
n=\frac{360}{\Delta R \times 4290}
$$

Payback periods produced by incremental rate reductions are shown in Table 1-12.

\section{Table $1-12$}

PAYBACK PERIOD DERIVED FOR A GIVEN AR IN-GROUND HEAT STORAGE

$\underline{\Delta R(\$ / k W h)}$

.02

.04

.06

.08 n. (years)

4.2

2.1

1,4

1.0 
In-Ground Heat Storage

Equipment Manufacturer

Smith-Gates Corporation

1451 New Britain Avenue

Farmington, Connecticut 06032 


\section{THIS PAGE}

\section{WAS INTENTIONALLY \\ LEFT BLANK}


Table 1-13

In-Ground Heat Storage Projects Summary

$$
\text { vtility }
$$
clievel and Electric
Illuminati ing conpany Commonweal th Edi son
Company

Dairyland Power Cooperative

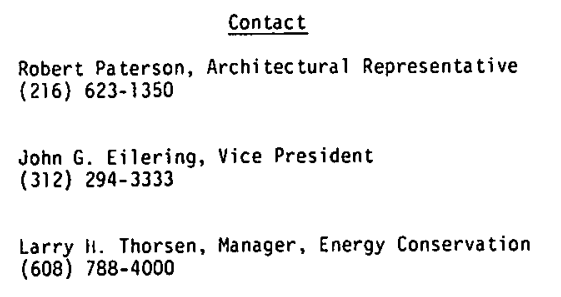

Eguipment
Smith-Gates
Deepheat
Smith-Gates
Deepheat
Smith-Gates
Deepheat

\begin{tabular}{|c|c|c|}
\hline$\frac{\text { Control }}{\text { Time }}$ & Sample & Incentive \\
\hline $\begin{array}{l}\text { Time wsitch and } \\
\text { trerrost tats }\end{array}$ & $\begin{array}{l}\text { 8 industrtial } \\
\text { buildings }\end{array}$ & Reduced denand charges \\
\hline $\begin{array}{l}\text { Time switch and } \\
\text { thermos tats }\end{array}$ & 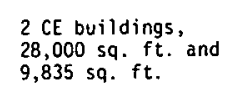 & Reduced peak demand \\
\hline Time switches & $\begin{array}{l}600 \text { houses } \\
200 \\
\text { 200 nor-residential } \\
\text { buildoings }\end{array}$ & Off-peak rate \\
\hline
\end{tabular}

None
Menand meters on heating
Monit toring discontinued

Moni tori ing discontinued
Status

completed

Completed

Completed
(started
ig6i)
Results/Remarks

Excel lent results.

Contact Date
Excel lent results.

August 16, 1978 


\section{THIS PAGE}

\section{WAS INTENTIONALLY \\ LEFT BLANK}




\subsection{ICE STORAGE AIR CONDITIONING}

\section{Technical Characteristics}

Sixty-five percent of the utilities in the United States are summer peaking. Due to the high variability of air conditioner loads, these utilities have a greater daily load variation (poor daily load factor) than do winter peaking utilities. In order to limit growth of the summer peak and to improve the daily load factor, utilities have begun to test ice storage systems in residential and commercial applications.

At present, the most efficient and economical method of storing energy to meet on-peak cooling requirements appears to be the freezing of water in a well-insulated tank. Systems using ice as a storage medium take advantage of the heat of fusion, permitting the use of smaller storage reservoirs. One pound of ice will absorb 144 Btu's as it melts, while one pound of chilled water will absorb only one Btu when raised $1^{\circ} \mathrm{F}\left(.56^{\circ} \mathrm{C}\right)$.

A typical ice storage system uses a conventional heat pump or air conditioning condensing unit, modified by the substitution of a liquid chiller or immersion evaporator for a conventional evaporator. The major differences between ice storage systems have to do with the way the ice is frozen and stored. Ice storage systems are generally classified as either static or dynamic.

One static system uses a conventional condensing unit coupled with a liquid chiller. An antifreeze solution is circulated through the chiller and through a specially designed heat exchanger positioned in a 300-gallon (1136-1iter), water-filled, plastic storage tank. This hed exchanger consists of a coiled mat of plastic tubing equally spaced throughout the tank, which produces a uniform build-up of ice. 
Another static system uses a modified water heater tank for storage of ice, and involves direct refrigerant-to-ice heat exchange via an immersion evaporator.

A third static system also makes use of direct heat exchange for ice generation by freezing water concentrically to about 80 feet $(24.4 \mathrm{~m})$ of refrigeration tubing in an insulated rectangular tank. At full charge the ice forms into vertical sheets separated by water-filled spaces.

An example of dynamic ice generation and storage is the "ice shucking" technique. Water is flowed over chilled plates and forms into a thin layer of ice. Hot gas is then passed thrnugh the plate which melts the ice layer away from the plate. The ice falls into a storage tank and the cycle repeats.

In all systems, house cooling is accomplished by circulating water or antifreeze from the storage tank through a duct coil and back to the storage tank.

Monitoring and control of the system is typically handled by a mechanical and electrical control package, which includes any necessary thermostats, timers and relays, and control logic. Systems will normally include override and low limit thermocouples, located in the insulated tank, which, in the event of unusually heavy cooling loads, will allow on-peak operation of the condensing unit.

\section{System Cost and Payback}

Two manufacturers have supplied cost information on ice storage systems.

Manufacturer A - Residential-sized storage systems, rated at 34 ton-hour storage capacity, carries a projected installed cost of $\$ 2000$. This figure includes the cost of the storage tank and associated hardware, bul dues not include the cost of the condensing unit. As such, this $\$ 2000$ represents the projected 
difference in initial installed costs $(\Delta I C)$ for an ice storage system compared to a conventional air conditioner.

Installed costs for commercial-sized systems are projected to be $\$ 20$ per ton-hour of storage capacity.

Manufacturer B - Projected retail cost of the residential storage system is $\$ 2500$, not including the cost of the condensing unit. This manufacturer has halted production of this system indefinitely because of unfavorable market projections. No commercial-sized hardware is planned, although it is felt that a potential market exists.

A third manufacturer designed and built about ten ice storage tank units for test installations by utilities, but in early 1979 manufacture was discontinued.

Several utilities have designed and built ice storage units to their own specifications.

Because manufacturer $A$ is the only manufacturer presently involved in the residential ice storage market, the quoted $\triangle \mathrm{IC}$ of $\$ 2000$ will be used for the cost comparison with a conventional electric air conditioner.

Since the economics of ice storage systems improve with increasing cooling loads, the analysis will be done for both the Pittsburgh cooling load (from Table 1-3) and the load calculated for Atlanta, Georgia, taken from the same computer study.

For Pittsburgh, the required average cooling kWh is 1790, while for Atlanta the requirement, is $3250 \mathrm{kWh}$. Therefore

$$
n_{\text {Pit }}=\frac{2000}{1790 \times \Delta R}
$$

while

$$
n_{\text {At } 1}=\frac{2000}{3250} \times \Delta R
$$


where

$$
\begin{aligned}
& n_{\text {Pit }}=\text { payback period for Pittsburgh } \\
& n_{A t 1}=\text { payback period for Atlanta }
\end{aligned}
$$

Table 1-14 shows the payback periods derived for a given $\Delta R$ for both the Pittsburgh and Atlanta loads.

$$
\text { Table 1-14 }
$$

PAYBACK PERIOUO ULRIVEU FUR A GIVEN $\triangle R$ ICE STORAGE

\section{$\underline{\Delta R(\$ / k W h)}$}

.02

.04

.06

.08 $n$ years

(Pittsburgh)

55.9

27.9

18.6

14.0 $n$ years

(Atlanta)

30.8

15.4

10.3

7.7

The payback periods derived for residential ice storage, even when using the Atlanta cooling load information, are longer than would be the anticipated life of the systems' maior component.s. As sursh, the economic feasibility of these systems for residential applications is highly questionable.

This postulation is supported by the fact that all ice storage manufacturers have either withdrawn from the market entireiy or have redirected their efforts towards the commercial sector application of ice storage air conditioning.

The commercial sector represents a promising area for ice storage air conditioning for several reasons:

- Many commercial air conditioning systems use chilled water distribution systems. As such, many of the mechanical components necessary for a storage system 
(except for an ice storage reservoir) are already in place. This, along with the economies-of-scale resulting from the large capacity requirements of commercial air conditioning, can result in a proportionately lower $\triangle \mathrm{IC}$.

- Commercial buildings often require air conditioning on a year-round or extended season basis. This results in higher energy consumptions, which would yield greater $\triangle A O P C$.

- The incentive rates necessary to induce conversion to a storage system are already in effect (in the form of monthly demand charges) in the commercial sector. 
Ice Storage Air Conditioning

Equipment Manufacturers

A. 0. Smith Corporation

Consumer Products Division

P.0. Box 28

Kankakee, Illinois 60901

Calmac Manufacturing Corporation

150 South Van Brunt Street

Englewood, New Jersey 07631

Caloskills Thermal Energy Storage Systems

Division of Girton Manufacturing Co.

Millville, Pennsylvania 17816

Carrier Corporation

Carrier Tower

Syracuse, New York 13201 
Table 1-15

Ice Storage - Resident ial Projects Sumary

\begin{tabular}{|c|c|c|c|c|c|c|c|c|c|}
\hline $\begin{array}{l}\text { Arkansas Power and Light } \\
\text { Company }\end{array}$ & $\begin{array}{l}\text { Contact } \\
\text { Ed GG. Barry, Jr.. Manager of Technical } \\
\text { Services } \\
\text { (501) 371-7969 }\end{array}$ & $\begin{array}{l}\text { Equipment } \\
\text { A.0. Smith }\end{array}$ & $\underset{\substack{\text { Radio and } \\
\text { thermos tats }}}{\frac{\text { Control }}{\text { ton }}}$ & 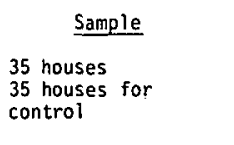 & $\begin{array}{c}\text { Incentive } \\
\text { sls5/test house, s50/control } \\
\text { house, plus equi prent cost }\end{array}$ & $\begin{array}{l}\text { Monitoring } \\
\text { Magnetic cape on energy } \\
\text { use enc temperaturere }\end{array}$ & $\begin{array}{l}\text { Status } \\
\text { Installations } \\
\text { starting }\end{array}$ & $\begin{array}{l}\text { Results/Remarks } \\
\text { Not yet determined. DOE/ORML } \\
\text { project. }\end{array}$ & $\begin{array}{l}\text { Contact Date } \\
\text { June 1, } 1979\end{array}$ \\
\hline $\begin{array}{l}\text { 8altimore Gas and Electric } \\
\text { Company }\end{array}$ & $\begin{array}{l}\text { Mitchel1 W. Shapiro, Associate Engineer } \\
(301) 265-7500\end{array}$ & carrier & $\begin{array}{l}\text { Time switch and } \\
\text { thermos tats }\end{array}$ & 2 houses & $\begin{array}{l}\text { sloo/year plus free } \\
\text { maintenance }\end{array}$ & EPRI monitoring program & Test continuing & $\begin{array}{l}\text { Operation sat isfactory. Data } \\
\text { onal ysis pending. }\end{array}$ & June 12, 1979 \\
\hline Consoli idated Ed ison Company & $\begin{array}{l}\text { Dennis P. Puirk, Assistant vice President, } \\
\text { conservation Services } \\
\text { (212) } 460-6539\end{array}$ & Callac & $\begin{array}{l}\text { Iime switch and } \\
\text { therriostats }\end{array}$ & 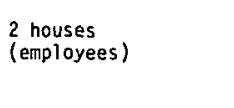 & None & $\begin{array}{l}\text { Magnetic tape. EPRI monitoring } \\
\text { on one. }\end{array}$ & $\begin{array}{l}\text { One unit removed. } \\
\text { one replaceded Test } \\
\text { continuing. }\end{array}$ & $\begin{array}{l}\text { Some problems. Replacemene unit } \\
\text { improved. }\end{array}$ & May 1, 1980 \\
\hline Duke Power Company & 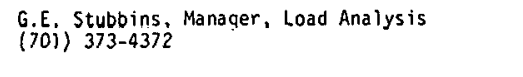 & Carrier & $\begin{array}{l}\text { Time switch and } \\
\text { thermostats }\end{array}$ & 1 house & Lower equi pnent cost & $\begin{array}{l}\text { Mangetic tape plus EPRI } \\
\text { monitoring }\end{array}$ & Completed & EPRI data analysis pending. & April 30, 1980 \\
\hline Georgia Power Company & $\begin{array}{l}\text { D.66 Sabin, Manager, Energy Research } \\
\text { (4004) } 522-6060 \text { (1) }\end{array}$ & GP-des igned & $\begin{array}{l}\text { Time, float and } \\
\text { flow switches }\end{array}$ & 1 house & $\begin{array}{l}\text { None. Buyer of house agreed } \\
\text { to two-year test. }\end{array}$ & $\begin{array}{l}\text { Magnetic tape on energy } \\
\text { use and temperature }\end{array}$ & $\begin{array}{l}\text { Monitoring started } \\
\text { May 15, } 1979\end{array}$ & Not yet determined. & May 25, 1979 \\
\hline $\begin{array}{l}\text { Gulf f tates Utilities } \\
\text { company }\end{array}$ & $\begin{array}{l}\text { Richard Peternan, Manager, Custoner } \\
\text { Servicese } \\
(713) \text { 838-6631 }\end{array}$ & $\begin{array}{l}\text { Lanar nuiversitityi } \\
\text { desiqned and built }\end{array}$ & $\begin{array}{l}\text { lime switch and } \\
\text { thermostats }\end{array}$ & 1 house & None. (TOO rate later) & Magnetic tape on energy use & Test continuing & $\begin{array}{l}\text { Report in iraft form. } \\
\text { successful for load shifting. }\end{array}$ & Apri1 28, 1980 \\
\hline $\begin{array}{l}\text { Jersey Central Power and } \\
\text { Light Company }\end{array}$ & $\begin{array}{l}\text { David L. Thompson, Director, Technical } \\
\text { services } \\
(201) \text { 386-5700 }\end{array}$ & Carrier & $\begin{array}{l}\text { Time switch and } \\
\text { thermostats }\end{array}$ & $\begin{array}{l}\begin{array}{l}\text { house } \\
\text { (employee) }\end{array} \\
\text { (a) }\end{array}$ & Too rate & $\begin{array}{l}\text { Magnetic tape on energy } \\
\text { use and temperature }\end{array}$ & Test completed & $\begin{array}{l}\text { Report avai lable, House cool ing } \\
\text { satifficatcory. } 848 \text { off-peak. } \\
\text { Economics unf avorable }\end{array}$ & Apri1 29, 1980 \\
\hline $\begin{array}{l}\text { Kansas Gas and Electric } \\
\text { Company }\end{array}$ & 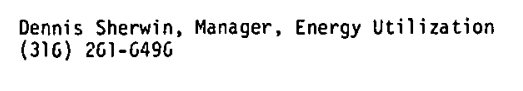 & carrier & $\begin{array}{l}\text { Time switch and } \\
\text { thermostats }\end{array}$ & $\begin{array}{l}2 \text { unils in } \\
\text { duplex house }\end{array}$ & $\begin{array}{l}\text { Exparimental too rate } \\
\text { plus equipment }\end{array}$ & $\begin{array}{l}\text { Magnetic tane pluS FPRT } \\
\text { monitoring }\end{array}$ & Test conntinuing & Not yet determined. & May 8. 1980 \\
\hline $\begin{array}{l}\text { Long Island Lighting } \\
\text { Company }\end{array}$ & $\begin{array}{l}\text { Rahbert E. Ashburn, Manager, Economic } \\
\text { Reserch } \\
\text { (516) } 228-2195\end{array}$ & Calmac & $\begin{array}{l}\text { Radio and } \\
\text { thermostats }\end{array}$ & $\begin{array}{l}50 \text { houses } \\
35 \text { control houses }\end{array}$ & 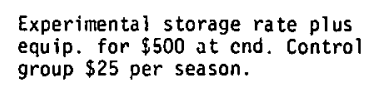 & $\begin{array}{l}\text { Magnetic tape on energy use } \\
\text { and air temperature }\end{array}$ & $\begin{array}{l}\text { Test continining } \\
\text { to Decenber } 1981\end{array}$ & $\begin{array}{l}\text { Not yet determined. DoE/ORNL } \\
\text { project. }\end{array}$ & Apri1 29, 1980 \\
\hline $\begin{array}{l}\text { Orange and Rockland } \\
\text { Utílitites, Inc. }\end{array}$ & $\begin{array}{l}\text { lilytitora Herbst, Project Manager } \\
(194) \text { 627-2400 }\end{array}$ & Colmac & Time switch & 1 large house & Special too rạte & Magnetic tape & In service & Not yet determined. & August 21, 1980 \\
\hline $\begin{array}{l}\text { Pacificic Gas and Electric } \\
\text { Conpany }\end{array}$ & $\begin{array}{l}\text { R.M. Mertz, Manager, Energy Conservation } \\
\text { and Services } \\
\text { (415) 781-4211 }\end{array}$ & $\begin{array}{l}\text { Carrier-cirton, } \\
\text { retroficted arir } \\
\text { conditioning }\end{array}$ & Radio & $\begin{array}{l}30 \text { existing houses } \\
30 \text { control houses }\end{array}$ & $\$ 6 /$ month May through September & $\begin{array}{l}\text { Magnetic tape on energy use } \\
\text { and air temperatures }\end{array}$ & In service & $\begin{array}{l}\text { Not yet determined. DOE/ORRL } \\
\text { project. }\end{array}$ & September 18, 1980 \\
\hline $\begin{array}{l}\text { Pubbic Service company } \\
\text { of Indiana }\end{array}$ & 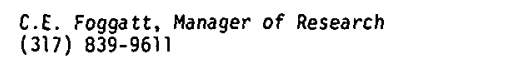 & $\begin{array}{l}\text { Psy des ing, } \\
\text { Bryant compressor }\end{array}$ & $\begin{array}{l}\text { Time switch and } \\
\text { thememostats }\end{array}$ & 1 house & None & Strip charts plus EPRI moni toring & Test continuing & $\begin{array}{l}\text { Not yet deterermined. Report } \\
\text { at eno of f } 990 \text { season. }\end{array}$ & July 12, 1979 \\
\hline $\begin{array}{l}\text { Public Scrvice Electric } \\
\text { and Gas Company }\end{array}$ & $\begin{array}{l}\text { Fred Thurkewaf, ir., Manager, Laad Mana gererent } \\
(201) \text { 430-7245 }\end{array}$ & $\begin{array}{l}\text { Calmac Ice bank, } \\
\text { Caloski ils Ice Bank }\end{array}$ & Time switch & $\begin{array}{l}3 \text { houses } \\
\text { (employees) }\end{array}$ & Time-of-use rate & Magnetic tape & Starts late 1980 & Not yet determined. & April 24, 1980 \\
\hline Salt River Project & $\begin{array}{l}\text { Lee Ather, Manager, Custoner Energy } \\
\text { Nanaegent } \\
\langle 002\rangle=27-5900\end{array}$ & Carrier-Girton & $\begin{array}{l}\text { Tine switch and } \\
\text { thermostats }\end{array}$ & nouses & $\begin{array}{l}\text { Cooling costs } \\
\text { reimbursed }\end{array}$ & $\begin{array}{l}\text { Magnetic tape on energy use, } \\
\text { temerarature, and flow rates }\end{array}$ & $\begin{array}{l}\text { Three install led, } \\
\text { one pending. }\end{array}$ & $\begin{array}{l}\text { Tests succiessful. Dato } \\
\text { analysis pending. }\end{array}$ & May 0, 1980 \\
\hline Union Electric Company & 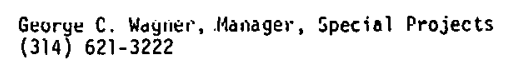 & Carricr & $\begin{array}{l}\text { Time switch and } \\
\text { thermostats }\end{array}$ & 1 house & Water heating block rate & EPRI monit toring & Test continuing & Not yet deternined. & June 6, 1979 \\
\hline $\begin{array}{l}\begin{array}{l}\text { Wisconsin Electric Power } \\
\text { Company }\end{array} \\
\text { S }\end{array}$ & 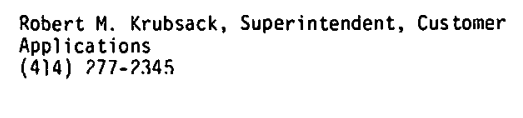 & 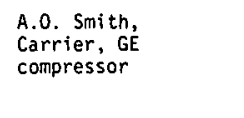 & $\begin{array}{l}\text { Power line carrier } \\
\text { and thernos tats }\end{array}$ & $\begin{array}{l}35 \text { houses, } 2 \text { ice } \\
\text { tanks } 535 \text { houses, } \\
\text { 1 ice tank } 25 \\
\text { control houses }\end{array}$ & $\begin{array}{l}\text { S10/montn - } 24 \text { months. } \\
\text { Equimente price } \\
\text { concessioni at end. }\end{array}$ & $\begin{array}{l}\text { Magnetic tape on energy use, } \\
\text { temperature, and humidity }\end{array}$ & $\begin{array}{l}\text { Installation } \\
\text { complete. Moni- } \\
\text { toring being- } \\
\text { installed. }\end{array}$ & $\begin{array}{l}\text { Mot yet determined. DoE/ORNL } \\
\text { project. }\end{array}$ & July 27, 1979 \\
\hline
\end{tabular}


THIS PAGE

\section{WAS INTENTIONALLY LEFT BLANK}


Table $1-16$

Ice Storage - Commerc ial Projects Sumary

\begin{tabular}{|c|c|}
\hline Utility & contact \\
\hline $\begin{array}{l}\text { Commonnea th Edison } \\
\text { Company }\end{array}$ & 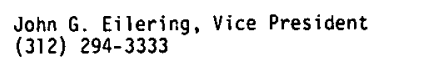 \\
\hline Georgia Power Company & $\begin{array}{l}\text { D.6. Sabinin, Manager, Energy Research } \\
\text { (4004) } 522-60000\end{array}$ \\
\hline $\begin{array}{l}\text { Culf States Utili ties } \\
\text { Company }\end{array}$ & 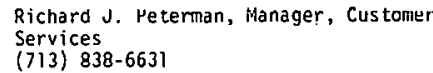 \\
\hline $\begin{array}{l}\text { Philadel phia Electric } \\
\text { Conpany }\end{array}$ & $\begin{array}{l}\text { E. Martin Shane, Supervisor, Technical } \\
\text { Analysis } \\
\text { alis }\end{array}$ \\
\hline Salt River Project & 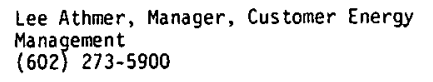 \\
\hline $\begin{array}{l}\text { Southern Cal ifornia Edison } \\
\text { Conpeny }\end{array}$ & $\begin{array}{l}\text { EAA Aysers, J., Vice President } \\
\text { (213) }\end{array}$ \\
\hline Ictric Poner & 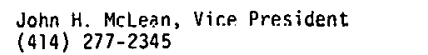 \\
\hline
\end{tabular}

\begin{tabular}{|c|c|c|c|}
\hline 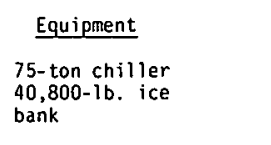 & $\underset{\text { Time switch }}{\stackrel{\text { control }}{\text { Tit }}}$ & 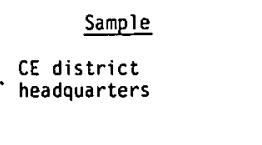 & $\begin{array}{l}\frac{\text { Incentive }}{\text { Denand reduction }} \\
\text {. }\end{array}$ \\
\hline GP-designed & $\begin{array}{l}\text { Time switch and } \\
\text { float } s w i t c h\end{array}$ & 1 GP district office & off-peak rider \\
\hline Coloskil11s A-40 & Time switch & One building & Demand charge reduction \\
\hline $\begin{array}{l}\text { PE-designed } \\
\text { (rertrofit of } \\
\text { air conditioning) }\end{array}$ & Not determined & $\begin{array}{l}\text { Information center at at } \\
\text { nucl lear power plant }\end{array}$ & None \\
\hline $\begin{array}{l}\text { Girton - two } \\
10 \text { - tor chillers } \\
13,550 \mathrm{lb} \text { ice storage }\end{array}$ & Time switch & 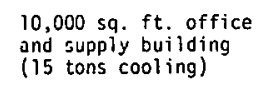 & Mone \\
\hline 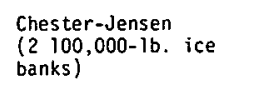 & Time switch & $\begin{array}{l}168.000 \text { sa. ft. } \\
\text { industrial buiding }\end{array}$ & Time-of-Use rate \\
\hline 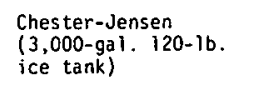 & Time switch & $\begin{array}{l}\text { 35,000 sq. ft. WEP } \\
\text { service center }\end{array}$ & $\begin{array}{l}\text { Eemand reduction and } \\
\text { Ton rate later }\end{array}$ \\
\hline
\end{tabular}

Monitoring
Magnetic tape on energy use
and temperatures

Magnetic tape on energy use,
temperature, and water flow"

Magnetic tape on total load,
air conditioninin, ice maker,
and heat ter strips

Magnetic tape on energy use
and temperature

Magnetic tape on energy use,
temperature, and flow rates

Magnetic tape on energy use,
remperature, and flow rates

watthour meters plus EPH1
moni toring status

Results/Renarks

Oelayed. building
construct ion not
started yet determined.

In service Not yet determined.

Parts on order Not yet Jetermined.

Test continuing Not yet determined.

Test continuing
for 2 yearrs
startec Apri 1979)

Test continuing Not yet determined.
Contact Date

May 25, 1979

July 14, 1980

May 5, 1980

May 8, 1980

May 1, 1980

June 28, 1978 
THIS PAGE

\section{WAS INTENTIONALLY LEFT BLANK}


ARKANSAS POWER \& LIGHT COMPANY

P.0. BOX 551

Little Rock, Arkansas 72203

NEW 1979

(501) $371-7696$

Ed G. Barry, Jr., Manager of Technical Services

SYSTEM: $\quad$ Ice Cool Storage - Residential

SUMMARY: The cool storage equipment will be installed in 35 selected existing homes, each with 2-1/2- to 3-ton central air conditioning systems. The cool storage systems are to be monitored with magnetic tape recording equipment to determine appropriate rate design, potential reduction in peak load, operation and maintenance cost, and customer satisfaction with cool storage systems. The cool storage system consists of two or three well-insulated storage tanks, each containing an evaporator coil. The existing air-cooled condensing unit will be connected to the storage tank evaporators to freeze ice in the tanks during the offpeak hours. Cooling will be supplied to the residence whenever needed by circulating chilled water from the tanks through the existing indoor evaporator coil. The condensing unit will be de-energized during peak hours by using a radio-controlled switch.

EQUIPMENT: A. 0. Smith 120-gallon ice storage tanks and Motorola radio system.

CONTROL: Radio.

TEST

ENVIRONMENT: Existing homes have 2-1/2- to 3-1/2-ton central air conditioning. 
SAMPLE: The cool storage system will be installed in 35 homes with existing central air conditioning units in the Little Rock, Arkansas area. These homes will be monitored along with 35 control homes for comparison.

INCENTIVE: At the end of each test year, test home participants will receive $\$ 150$ and control home participants $\$ 50$. AP\&L will also provide all air-conditioning repairs and maintenance for both the test and control homes. After the test is concluded, the test home participants may keep the ice storage equipment or have the storage equipment replaced by a conventional system at no cost l.1 Ihe!n!.

MONITORING: Magnetic tape recorders will be used to record total usage, condensing unit usage, indoor fan usage, circulating pump usage, circulating water flow, outdoor temperature, indoor temperature, indoor relative humidity, entering water temperature, and exiting water temperature.

INTERVIEW

DATE: . June 1, 1979.

STATUS: $\quad$ Construction will start summer 1979 and recording of data will start with the completion of the first system.

RESULTS: $\quad$ Not yet available.

REMARKS: This is a DOE/ORNL project. 
CONSOLIDATED EDISON COMPANY

4 Irving Place

New York, New York 10003

REVISED 1980

(212) $460-6539$

Dennis P. Quirk, Assistant Vice-President, Conservation Services

Stephen A. Pertusiello, Utilization Engineer

SYSTEM: $\quad$ Ice Cool Storage - Residential

SUMMARY: In an attempt to determine technical and economic system feasibility, as well as compatibility with new TOD rates, Consolidated Edison installed two CALMAC ice storage units In August 1977. Testing of one unit was completed last summer. The second unit was replaced with a modified and improved CALMAC unit and will be tested through the summer of 1979. Load shifting will be assessed in these two homes on which energy use baseline data were accumulated during the summer of 1976. The project is scheduled for completion in 1979.

EQUIPMENT: 3-ton CALMAC static ice storage system.

CONTROL: Time switch controls off-peak charging. Thermostat controls on-peak cooling.

TEST

ENVIRONMENT: CALMAC systems are in two employee homes previously monitored by magnetic tape recorders.

SAMPLE: $\quad$ Two employee residences of optimum size for system capacity.

INCENTIVE: No incentive is offered in conjunction with these systems.

MONITORING: Magnetic tape recorders for total house usage; EPRI funded instrumentation on one ice storage system. 
INTERV IEW

DATE:

May 1980.

STATUS:

Two systems installed in August 1977. One unit removed in 1978. One unit replaced with an upgraded unit in 1979.

RESULTS: $\quad$ Not yet determined.

REMARKS: $\quad$ The CALMAC systems cost approximately $\$ 7,000$ per ton installed. 
GULF STATES UTILITIES COMPANY

NEW 1980

P.0. Box 2951

Beaumont, Texas 77701

(713) $838-6631$

Richard J. Peterman, Manager, Customer Services

SYSTEM: $\quad$ Ice Cool Storage - Commercial

SUMMARY: In an existing savings and loan branch office, previously cooled by a 5-ton chiller, an ice storage system has been installed. An automatic ice-thickness sensor, in series with the clock switch, shuts down the compressor when a preset thickness is reached.

EQUIPMENT: Caloskills A-40 Thermaster: 5-hp, 40-ton-hour capacity, $96^{\prime \prime} \times 60^{\prime \prime} \times 62^{\prime \prime}$ tank.

CONTROL: Clock - charging period 5:00 p.m. to 8:00 a.m.

TEST

ENVIRONMENT: Savings and loan branch office in Baton Rouge, Louisiana, 2,000 square feet.

SAMPLE: $\quad$ One building.

INCENTIVE: $\quad$ Demand charge reduction.

MONITORING: Magnetic tape metering on total service, air conditioning, ice maker, and heater strips.

STATUS: $\quad$ In service.

INTERVIEW

DATE:

JuTy 14, 1980.

RESULTS: $\quad$ Not yet determined. 
LONG ISLAND LIGHTING COMPANY

250 01d Country Road

Mineola, New York 11501

$\underline{\text { REV ISED } 1980}$

(516) $228-2195$

Robert E. Ashburn, Manager, Economic Research Department

John J. Kinirons, Manager, Load Research \& Load Management Division

SYSTEM: $\quad$ Ice Cool Storage - Residential

SUMMARY: Long Island Lighting Company, in conjunction with DOE and the Empire State Electric Energy Research Corporation, is participating in a national energy storage demonstration program that w11l involve the installatiun of 50 residential cool storage systems. The storage system is designed to retrofit homes that already have existing central air conditioning. During operation, the existing compressor will freeze a 300-gallon tank of water in off-. peak hours and use it to cool a circulated liquid refrigerant. The test will measure the effective energy displacement from peak periods to off-peak periods. Participating customers will be billed for the energy consumed by the cool storage system, under the provisions of a special experimental storage rate specifically established for this program. Customers are further guaranteed that the cost of opcration will not exceed normal cooling costs adjusted for current prices and degree days. Billing will be based on this storage rate for energy used between midnight and 7 a.m., and at the residential service rate for all other hours in which the system uses energy. In addition to the 50 test homes, 35 homes having existing central air conditioning will be selected to serve as the control group. The test is scheduled for two cooling seasons.

EQUIPMENT: An Icebank-32 Coolness Storage System produced by Calmac Manufacturing Corporation has been installed at each test home. The major components include a storage module, a 
mechanical package, and an electrical control box.

CONTROL: To remotely control the cool storage systems, a Scientific Atlanta radio receiver has been installed above the electric meter at each test home. Periodically, Long Island Lighting Company will implement various control strategies by altering the time periods in which the cool storage system is allowed to charge or restore its cooling capacity. The objective is to determine optimum control strategies that provide both adequate charging time and keep the storage system from charging during Long Island Lighting Company's peak period. Further control will also be achieved locally with a General Electric IR-70 meter that will be pre-programmed to allow the storage system to charge between the hours of midnight and 7 a.m.

TEST

ENVIRONMENT: Selected house size does not exceed 2,000 square feet of living space and all are single family dwellings. Family size is three to five persons.

SAMPLE: $\quad 50$ homes of various architectural designs. Each is presently equipped with a central air conditioning system having a compressor-condenser 2-1/2 to 5 tons in size.

INCENTIVE: Experimental storage rate. Option to purchase storage system for $\$ 500$ at end of project. Control group customers will receive a $\$ 25$ check at the conclusion of each cooting season.

MONITORING: The following data is being collected at the 50 homes equipped with the storage system: total load to home, load to storage, indoor ambient air temperature, air flow, cooled air storage temperature, return air temperature. The following data is to be collected at the 35 homes 
equipped with central air conditioning without storage:

air conditioning load, total house load, indoor and outdoor ambient temperature.

INTERV IEW

DATE:

Apri1 29, 1980.

STATUS: In service.

RESULTS: $\quad$ Not yet determined. 
ORANGE AND ROCKLAND UTILITIES, INC.

NEW 1980

One Blue Hill Plaza

Pearl River, New York 10965

(914) $627-2400$

Clifford Herbst, Project Manager

SYSTEM: $\quad$ Ice Cool Storage - Residential

SUMMARY: In a large estate house Orange and Rockland Utilities is monitoring a Calmac ice storage system that includes six three-ton heat pumps.

EQUIPMENT: Calmac ice storage system with six three-ton heat pumps.

CONTROL: Time switch.

TEST

ENVIRONMENT: Large estate house.

SAMPLE: $\quad$ One house.

INVENTIVE: Special time-of-day rate. Off-peak 10:00 p.m. to 10:00 a.m.

MONITORING: Magnetic tape on total load, cooling load, and storage temperature.

INTERVIEW

DATE:

August $21,1980$.

STATUS: $\quad$ Monitoring started in September 1979.

RESULTS: $\quad$ Not yet determined. 
PACIFIC GAS AND ELECTRIC COMPANY

REV ISED 1980

77 Beale Street

San Francisco, California 94106

(415) 781-4211

R.M. Mertz, Manager, Energy Conservation and Services

SYSTEM: $\quad$ Ice Cool Storage - Residential

SUMMARY: In 30 homes, Carrier-Girton ice storage tanks and equipment will store cool using retrofitted air conditioning systems. Comparison will be made with 30 homes in a control group, not retrofitted. All homes in both groups will he. instrumented for lnad research data while fivc homes with ice storage will have device-specific data acquisition.

EQUIPMENT: Carrier-Girton ice storage systems.

CONTROL: $\quad$ Motorola radio from Fresno Dispatch Center.

TEST

ENV IRONMENT: 1,200-to 2,000-square-foot houses in Fresno. Cooling degrèe days--1,230. Dèsign temperature--101\% $\mathrm{F}$.

SAMPLE: $\quad 30$ retrofitted existing hnuses. 30 control group houses. Stratified by income level.

INCENTIVE: $\quad \$ 6$ per month, maintenance and excessive energy consumption reimbursed (on test homes only) from May through September.

MONITORING: At 60 homes, magnetic tape on: total power, power to compressor, and indoor temperature. At five ice bank houses, additional magnetic tape on: pump power, inlet and outlet temperatures. Chilled water flow is being measured but not electrically recorded.

INTERV IEW

DATE: $\quad$ September 8, 1980. 
STATUS: The equipment has been installed and tested for one summer. Modifications have been made to compensate for large scale equipment failures. Project to be concluded at end of summer 1981.

RESULTS: $\quad$ Not yet determined. 
PUBLIC SERVICE ELECTRIC AND GAS COMPANY

NEW 1980

80 Park Place

Newark, New Jersey 07101

(201) $430-7245$

Fred Thurkauf, Jr., Manager, Load Management

Clark W. Gellings, Assistant Manager, Load Management

SYSTEM: $\quad$ Ice Cool Storage - Residential

SUMMARY: Public Service Electric and Gas Company plans to evaluate commercially available residential customer-side cool storage devices utilizing ice storage for the retrnfit. market and the impact of such equipment on the summer daily load shape.

FUNCTION: $\quad$ To evaluate cool storage equipment and economics.

EQUIPMENT: One Calmac Ice Bank 32, one Caloskills King Zero Ice Builder, and one A. 0. Sirith Ice Bank Tank System (three tanks).

SAMPLE: $\quad$ Three employee volunteers.

INCENTIVE: $\quad$ Reduced air conditioning operating costs through timeof-use rate.

MONITORING: Detailed metering of all homes and equipment for energy use and thermal flows.

INTERVIEW

DATE:

Apri1 24, 1980.

STATUS: $\quad$ Planned for late 1980.

RESULTS: $\quad$ Not yet available. 
SALT RIVER PROJECT

Agricultural Improvement and Power District

1521 Project Drive

Tempe, Arizona

(602) $273-5900$

Mailing Address:

P.0. Box 1980

Phoenix, Arizona 85007

Lee Athmer, Manager, Customer Energy Management

SYSTEM: $\quad$ Ice Cool Storage - Commercial

SUMMARY: $\quad$ A well-monitored commercial test project has been initiated by Salt River Project to assess the capability of a static ice cool storage system in the Arizona climate. Equipment performance monitoring points are installed. Salt River Project also hopes to determine load shifting potential and to conduct rate research as corollary objectives.

EQUIPMENT: $\quad$ A 13,500-1b. Girton ice storage system storage tank is located outdoors, adjacent to two 10-ton water chillers and a cooling tower.

CONTROL: $\quad$ Time switch for off-peak charging.

TEST

ENVIRONMENT: One site location. Chilling requirement is 15 tons. Cooling degree-days--3,508. Design temperature-- $110^{\circ} \mathrm{F}$.

INCENT IVE: None.

MONITORING: Includes kWh consumption and $\mathrm{kW}$ demand for total cooling and storage systems, indoor and outdoor temperature and humidity, flow rate, and Btu cooling load.

INTERV IEW

DATE:

May 8, 1980. 
STATUS: $\quad$ Equipment operational for 1979 cooling season.

RESULTS: $\quad$ Equipment is designed for bi-weekly valve-over of water and refrigerant lines in order to obtain an energy consumption comparison between conventional chilled water cooling and ice storage, using the same chilling equipment. Results pending further testing. 
SALT RIVER PROJECT

Agricultural Improvement and Power District

REVISED 1980

1521 Project Drive

Tempe, Arizona

(602) $273-5900$

Mailing Address:

P.0. Box 1980

Phoenix, Arizona 85001

Lee Athmer, Manager, Customer Energy Management

SYSTEM: $\quad$ Ice Cool Storage - Residential

SUMMARY: $\quad$ Four well-monitored test projects have been initiated by Salt River Project to assess the capability of a static ice cool storage system in the Arizona climate. Equipment performance monitoring points are installed. Salt River Project also hopes to determine load shifting potential and to conduct rate research as corollary objectives.

EQUIPMENT: Two Carrier ice storage systems. Storage tanks are mounted outside homes on $10^{\prime} \times 10^{\prime}$ concrete slabs with full hermetic off-the-shelf condensing units.

CONTROL: $\quad$ Time switches for off-peak charging on all units.

TEST

ENVIRONMENT: Four site locations. Chilling requirements are 3 -ton, 3-1/2-ton, 4-ton, and 5-ton. Cooling degree-days -3,508. Design temperature - $110^{\circ} \mathrm{F}$.

SAMPLE: $\quad$ Four installations: one 1,150-square-foot residence; one 1,400-square-foot residence; one 1,800-square-fuot residence; one 3,100-square-fnnt. mndel home of which 1,900 square feet are cooled using ice storage, the remainder using conventional cooling.

INCENTIVE: Varies, Sites occupied by families, cooling costs reimbursed. 
MONITORING: Includes kWh consumption and $\mathrm{kW}$ demand for total home heating, cooling and storage systems, indoor and outdoor temperature and humidity, water temperatures, flow rate, and condensing unit pressures.

INTERV IEW

DATE:

May 8, 1980.

STATUS: $\quad$ Three sites installed and operating; three sites in operation for 1979 cooling season. Equipment installed in fourth site.

RESULTS: $\quad$ Site 1 - Carrier/EPRI-funded RP1089 instrumentation, periding dald results. Prelinillary data indicates a seasonal EER of 4.79 .

Site 2 - Ice storage can provide the total cooling requirements. Condensing unit power loads can be shifted to the utility off-peak period.

Site 3 - Equipment is designed for bi-weekly valve-over of water and refriqerant lines in order to obtain an energy consumption comparison between conventional cooling and ice storage, using the same condensing unit. Results pending further testing.

Site 4 - Not yet determined. Will attempt to obtain empirical data on ice storage energy consumption. 
SOUTHERN CALIFORNIA EDISON COMPANY

P.0. Box 800

Rosemead, California 91770

E.A. Myers, Jr., Vice President

SYSTEM: $\quad$ Ice Cool Storage - Commercial
REVISED 1980

(213) $572-2001$

SUMMARY: $\quad$ Southern California Edison is submetering an ice storage system that consists of two 100,000-pound ice banks. This storage system is designed to carry the building cooling load during the on-peak hours. During mid-peak and offpeak times, the cooling load is handled by an instantaneous chiller. The system consists of three 150-hp screw compressors; one for the chiller and two to charge the ice banks. This system is designed for a 168,000-square-foot building, owned by an electronics manufacturer. This customer is on a time-of-use rate.

ÉQUIPMENT: Two 100,000-pound Chester-Jensen ice banks.

CONTROL: Cooling is provided by ice banks during on-peak periods: summer--noon to 6 p.m., winter--5 p.m. to 10 p.m.

TEST

ENV IRONMENT: $\quad 168,000$-square-foot industrial building, tilt-up construction, Garden Grove, California.

SAMPLE: One 168,000-square-foot industrial building.

INCENT IVE: Commercial time-of-use rate (TOU-8).

MONITORING: Submetering determines:

(1) kWh per ton supplied by storage

(2) storage losses

(3) cost-effectiveness of ice storage

(4) impact of nighttime condensing 
Monitoring point: six watthour meters; nine temperature points; three flow meters.

INTERVIEW

DATE:

May 1, 1980.

STATUS: $\quad$ Building completed January 1979; data collection begun April 1979 and will continue for two years. Programming for data reduction is presently underway.

RESULTS: Not available at this time. 
WISCONSIN ELECTRIC POWER COMPANY

P.0. Box 2046

NEW 1979

Milwaukee, Wisconsin 53201

(414) $277-2345$

Robert M. Krubsack, Superintendent, Customer Application-

SYSTEM: $\quad$ Ice Cool Storage - Residential

SUMMARY: Ice cool storage for air conditioning will be installed in 35 existing homes using two A. 0. Smith ice tanks and a full-size compressor for off-peak operation only, and in 35 additional homes using one ice tank and a half-size compressor for nearly continuous operation. A control group of 25 residences will have conventional central air conditioning. All homes will be fitted for load research instrumentation, while 5 full-storage and 5 half-storage residences will have device-specific instrumentation. Control will be through an existing two-way power line carrier system.

EQUIPMENT: A. 0. Smith ice storage tanks. Carrier and GE air conditioning units.

CONTROL: $\quad$ Power line carrier communication system.

TEST

ENVIRONMENT: Cooling degree-days, 600. Design temperature $95^{\circ} \mathrm{F}$.

SAMPLE: $\quad 70$ test homes and 25 control homes.

INCENTIVE: $\quad \$ 10$ per month for 24 months. Equipment price concession.

MONITORING: All houses - total house, compressor, fan, pump energy use. 10 houses - air and water temperature. 5 control houses indoor temperature and humidity. 
INTERVIEW

DATE:

July $27,1979$.

STATUS: All installations complete. Monitoring being installed.

RESULTS: $\quad$ Not yet determined. 


\subsection{COMBINATION HEAT AND "COOL" STORAGE}

\section{Technical Characteristics}

The TES systems found in this section are designed to perform as storage heating systems in the winter and as storage air conditioners in the summer. They are designed to improve daily load factors by charging and storing all or most of an entire day's heating/cooling requirements off-peak. Although these systems typically utilize a single, well-insulated tank for storage of both non-pressurized hot water in the winter and cool water and/or ice in the summer, in conjunction with a heat pump system, many variations exist. Some systems utilize separate heat/cool storage tanks, some utilize resistance heat only as opposed to heat pumps, and many incorporate solar collectors into their basic designs.

While these systems are, for the most part, custom designed and built for each particular application, one major project is utilizing a hybrid application of commercial or near commercial systems. Virginia Electric and Power Company is testing the heat/cool storage concept in 40 homes, each using a Megatherm unit (see Pressurized Water Heat Storage) along with a Carrier/Girton ice storage system.

Combined Heat and Cool Storage Manufactured Equipment

As mentioned above, the majority of these systems represent either custom designed equipment or the hybrid utilization of existing heat or cool storage equipment. These latter systems have been covered in detail in previous sections. Brief descriptions of the specialized prototype systems may be found in each project write-up. 
THIS PAGE

\section{WAS INTENTIONALLY LEFT BLANK}


Table $1-17$

Combination Heat and Cool Storage - Residential - Projects Summary

\begin{tabular}{|c|c|}
\hline utility & Contact \\
\hline GPU Service Corporation & 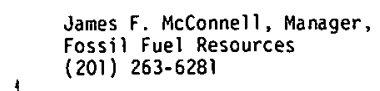 \\
\hline $\begin{array}{l}\text { Jersey Central Power and } \\
\text { Light Conpony }\end{array}$ & 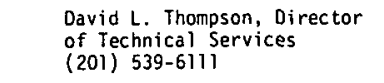 \\
\hline $\begin{array}{l}\text { Kansas Power and Light } \\
\text { company }\end{array}$ & $\begin{array}{l}\text { Marve Stacken, Program Manager } \\
\text { (1933) } \\
2333-1351\end{array}$ \\
\hline $\begin{array}{l}\text { Northern States Power } \\
\text { Compony }\end{array}$ & $\begin{array}{l}\text { Conrad J. Aas, Admini strator, } \\
\text { Research Programs } \\
\text { (612) } 330-5766\end{array}$ \\
\hline $\begin{array}{l}\text { Potonanc Electric Power } \\
\text { Conpany }\end{array}$ & $\begin{array}{l}\text { Thomas D. Edwards, Project } \\
\text { Engineer } \\
\text { (202) } 872-3078\end{array}$ \\
\hline Tennessee Valley Authority & $\begin{array}{l}\text { Patricia H. Harnis, Load } \\
\text { Manasement rranch } \\
(615) \text { 755-3591 }\end{array}$ \\
\hline $\begin{array}{l}\text { virginia Electric and } \\
\text { Power Company }\end{array}$ & 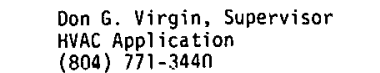 \\
\hline
\end{tabular}

\section{Equipment} Carrier coil, westinghous
chiller, calmac tank with
salts, solar coilector. Chiller - electric resistance
$(20 \mathrm{ku})$, 1000 -gal. storage KPPL-designed 2000 -gal.
tank, heat pump, solar

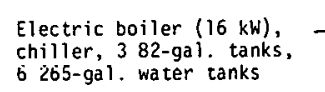

Westinghouse heat pump,
3 goo-gal.
collectors tanks, solar

Eus 500 -gal. tank and
heat pump

Carrier heat pump, Girton
tank, Megatherm$$
\text { Too meter }
$$$$
\begin{gathered}
\text { Sample } \\
2,500 \text { sq. ft. } \\
\text { house (employee) }
\end{gathered}
$$$$
\begin{aligned}
& \text { Time switch and } \\
& \text { thermos tat }
\end{aligned}
$$$$
\underset{\substack{\text { Time switch and } \\ \text { thermos tats }}}{1 \text { house }}
$$$$
\begin{gathered}
\text { Time switch and } \\
\text { themros tats }
\end{gathered}
$$$$
\begin{array}{ll}
\text { Time switch and } \\
\text { therrostats }
\end{array} \quad \begin{aligned}
& \text { house } \\
& \text { (enployee) }
\end{aligned}
$$$$
\begin{aligned}
& \text { Time switch and } \\
& \text { thermostats }
\end{aligned}
$$

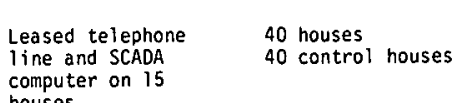

Monitoring Magnetic tape on electric
heat
condenand meters on
condensing units

Magnetic tape on energy
usseg.
record 4 -point temperature
recrist

Magnetic tape ó 'e nergy use
and tenperature, Betu meters

Magnetic tape on energy use,
tenperature, water frow

Magnetic tape on energy use,
teneprarture, water flow
meters

To0 meter ing

Magnetic tape on energy use
Status

Results/Remarks

Not yet avai ilable.

Contact date

completed

Operated successfully. GP
nas preparec a a report.

Not yet determined.

June 6, 1979

Test continuing Final report, September i980. August 14, 1980

Test continuing, Not yet determined.

June 1, 1979

Test: c.mmleted

Final report being prepare

Apri1 28, 1980

Partially
completed 
THIS PAGE

\section{WAS INTENTIONALLY LEFT BLANK}


Table 1-18

Combination Heat and Cool Storage - Commercial - Projects Summary

\begin{tabular}{|c|c|c|c|c|c|}
\hline utility & contact & Equipment & contrọl & Sample & Incentive \\
\hline $\begin{array}{l}\text { Bonneville Power } \\
\text { Admini is tration }\end{array}$ & $\begin{array}{l}\text { Oavid P. Hartann, Electrical } \\
\text { planning Engineer } \\
(5033) \text { 234-3361 }\end{array}$ & $\begin{array}{l}\text { Carrier heat pump, solar } \\
\text { collelectors, } 4,300 \text {-gal. } \\
\text { tank }\end{array}$ & $\begin{array}{l}\text { Manual by sub- } \\
\text { station operator }\end{array}$ & $\begin{array}{l}\text { Substation } \\
\text { building }\end{array}$ & None \\
\hline $\begin{array}{l}\text { Metropol i tan Edi ison } \\
\text { Company }\end{array}$ & $\begin{array}{l}\text { Robert Wh. Spiess, Admini istrator, } \\
\text { Technocidi services } \\
\text { (215) 921-6253 }\end{array}$ & Girton 3,420-gal. tank & $\begin{array}{l}\text { Time switch and } \\
\text { therrmos tats }\end{array}$ & $\begin{array}{l}\text { ME district } \\
\text { headquarters }\end{array}$ & Mone \\
\hline $\begin{array}{l}\text { Pennsylvania Power and } \\
\text { Light Company }\end{array}$ & $\begin{array}{l}\text { P.L. Roberts, Supervisor, } \\
\text { Research and Technical Services } \\
\text { (215) } 821-5151\end{array}$ & $\begin{array}{l}\text { Caloskilss thermal storage } \\
\text { system }\end{array}$ & Time switch & $\begin{array}{l}10,000 \mathrm{sq} \text {. ft. } \\
\text { office building }\end{array}$ & Unknown \\
\hline $\begin{array}{l}\text { virginia electric and } \\
\text { Poocrer rompany }\end{array}$ & 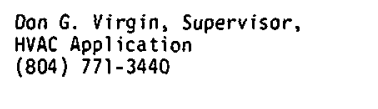 & 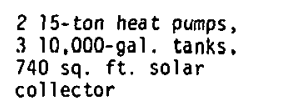 & $\begin{array}{l}\text { Time switch and } \\
\text { thermostats }\end{array}$ & $\begin{array}{l}\text { 18:500 sq. ft. } \\
\text { ver district office } \\
\text { and storeroom }\end{array}$ & \\
\hline
\end{tabular}

$$
\text { Monitoring }
$$

Magnetic tape on energy use

water flow meters
watelers,

Magnetic tape on electric neat.
Denand meters on condensing
units.

Magnetic tape on energy use
and temperature, 870 meters status

Test continuing

Test continu

Resul ts/Remarks $\quad$ Contact Date

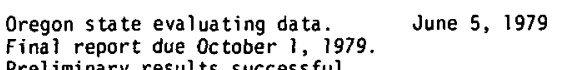

In service Not yet avai iable.

May 24, 1979

October 30, 1980

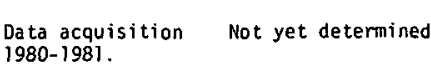

August 19, 1980 


\section{THIS PAGE}

\section{WAS INTENTIONALLY LEFT BLANK}


GPU Service Corporation

NEW 1980

100 Interpace Parkway

Parsippany, New Jersey 07054

(201) 263-6281

James F. McConnel1, Manager, Fossil Fuel Resources

SYSTEM: $\quad$ Combination Heat and Cool Storage - Residential

SUMMARY: $\quad$ This is an integrated residential system using heat storage tank, cool storage tank, an unglazed solar collector, and a non-reversing heat pump. The heat storage tank uses sodium thiosulfate pentahydrate as a phase change medium. Cool storage is in ice. The system provides a chiller to transfer heat from the cool tank to the hot tank. The solar collector can supply heat either to the cool tank for heat pumping or directly to the hot tank. An off-peak resistance heater provides supplemental heat. Domestic water heating is suppleilented by excess solar energy and heat pump capacity during milder weather. Ice generated by the chiller provides off-peak summer air conditioning.

EQUIPMENT: Condensing unit - five-ton Westinghouse split system air conditioner modified with a condensor bypass valve; Carrier Corporation air handler/water coil; Calmac heat tank and cool tank, 400 gallons each; Solar collector, 300-ft ${ }^{2}$ unglazed plastic mal.

CONTROL: Jersey Central Power and Light (JCP\&L) supplied time-ofday meter, whose contact time-controls the system control logic for the JCP\&L off-peak period (8:00 pm to 8:00 am, EST, weekdays and a 11 day Saturday and Sunday). 
TEST

ENVIRONMENT: Home of a GPU Service Corporation employee: $2500 \mathrm{ft}^{2}$; 6,000 degree days heating.

SAMPLE: $\quad$ Single installation.

INCENTIVE: None; JCP\&L residential tariffs provide an optional (RST) off-peak time-of-day rate, 8:00 pm to 8:00 am, EST, weekdays, and all weekend days. Current (summer '80) rates/kWh are $4.5 \$$ off-peak, a 11 year; $11.9 \$$ summer, and $8.0 \$$ winter on-peak, including base rate and energy adjustment. RST ratc provides a $\$ 1.50$ /month discount for solar water heating.

MONITORING: Four four-channel, load research type magnetic tape recorders; 24-point multichannel strip chart recorders; other manually read flow meters, Btu meters, a kWh meter, pressure gauges, and temperature gauges.

INTERVIEW

DATE:

JuTy $17,1980$.

STATUS: $\quad$ System is in service, planned to operate through winter 1981-82.

RESULTS: $\quad$ Heat storage operated during winter 79-80, using resistance heat and direct solar heat. Ice storage, cooling, and solar water heating test operated during summer of 1980. Phase change salt storage of off-peak electric resistance heating successfully resulted in all off-peak, heating energy input. Summer air conditioning with ice storage has also been all off-peak. 
NORTHERN STATES POWER COMPANY

REV ISED 1980

414 Nicolet Mall

Minneapolis, Minnesota 55401

(612) $330-57.66$

Conrad J. Aas, Administrator, Research Programs.

SYSTEM: $\quad$ Combination Heat and Cool Storage - Residential

SUMMARY: This is a unique installation that involves multiple systems and objectives. Space conditioning is accomplished by a combined water, heat, and cool storage system with off-peak charging. Domestic water is also heated off-peak. These systems are installed in a specially designed "super insulated" house which Northern States Power describes as "the highest level of insulation justifiable in today's economy." Objectives include technical and economic feasibility of the systems and the house design, plus effects of the systems on the electric demand characteristics in a single family residence. While final project evaluation will not be concluded until the fall of 1979, the space heating portion operated satisfactorily for the record cold winter of 1976-77. The space conditioning system uses 1,590 gallons of water that is heated to $200^{\circ} \mathrm{F}$ for heat storage by a 16-kW electric boiler and cooled to $50^{\circ} \mathrm{F}$ for cool storage by a water chiller. During on-peak hours the house is either heated or cooled by water circulated through a duct-mounted heating and cooling coil. Distribution of heat or cool is by a forced air system.

EQUIPMENT: Six 265-gallon water storage tanks. 16-kW electric boiler. Water chiller. Three 82-gallon, 3.8-kW domestic water heaters.

CONTROL: $\quad$ Space conditioning system is limited to off-peak charging by time switch. Hours--9 p.m. to $9 \mathrm{a} . \mathrm{m}$. The 16-kW boiler has four stages of $4 \mathrm{~kW}$, each controlled by a separate 
thermostat. These thermostats are set to turn on a stage at different outdoor temperatures. Room temperature thermostat regulates water flow to the coil by on-off control of the supply pump.

TEST

ENVIRONMENT: "Super insulated," all electric home, Two-story, 2,000 square feet. Design heat loss--26,800 Btu per hour. Design heat gain--20,245 Btu per hour. Insulation: ceilings--12 inches; walls--8-inch wall with full thick batt. Windows--double-glazed with storm windows. Controlled ventllation with heat recovery unit in attic. Degreedays--8,382. Design temperature--minus $25^{\circ} \mathrm{F}$ winter, $95^{\circ} \mathrm{F}$ summer.

SAMPLE: $\quad$ Single installation.

INCENTIVE: None.

MONITORING: Two 4-track magnetic tape recorders, one 24-point multipoint recorder and three register type water meters. Electric demand will be recorded at 15-minute intervals, including total house load, heating or cooling equipment load, domestic water heating load, and heating and cooling coil supply pump. Temperature difference across this coil, as well as various temperatures throughout the house, heating and cooling system, and the ventilation system will be recorded.

INTERVIEW

DATE:

July $9,1980$.

STATUS: In service.

RESULTS: Final report will be ready about August 1, 1980. Prelimin- 
ary report indicates that the system conserves energy but will not be economically feasible until Northern States

Power Company has a TOD rate. 
PENNSYLVANIA POWER \& LIGHT COMPANY

Two North Ninth Street

Allentown, Pennsylvania 18108

NEW 1980

P. L. Roberts, Supervisor - Research and Technical Services

SYSTEM:

Combination Heat and Cool Storage - Commercial

SUMMARY:

Pennsylvania Power \& Light Company is monitoring a combination heat and cool storage system installed in Millville Mutual Insurance Company office building in Millville, Pennsylvania.

EQUUIPMEENT :

Caloskils Thermal Storage System. The storage tank/ice builder usce a six stage $75 \mathrm{~kW}$ electric heater for the heating mode and two 7-1/2-hp condensing units for the ice building (cooling) mode. Two ạir handlers distribute the heated or cooled air. Various electric baseboard supplementary heaters exist in draft-prone areas.

TEST

ENV IRONMENT:

The structure is a two-story, 10,000-square-foot, colonial. design office building. The building is well insulated and has minimum glass area. Approximately one half the total space in the building is utilized at the preșent time.

SAMPLE: $\quad$ One office building.

INCENTIVE: Unknown.

MONITORING: $\quad$ Magnetic tape on $75-\mathrm{kW}$ clectric circulation heater. Two self-contained demand meters on condensing unit. Billing meter is also megnetic tape. 
INTERVIEW

DATE:

STATUS:
October 30, 1980.

Building occupied April 2, 1980. Data collection continuing.

Not yet available. 
TENNESSEE VALLEY AUTHORITY

NEW 1980

210 Power Building

Chattanooga, Tennessee 37401

(615) $755-3591$

Patricia H. Harris, Chief, Load Management Branch

SYSTEM: $\quad$ Comparative Heat Storaqe - Residential

SUMMARY: $\quad$ Tennessee Valley Authority, in cooperation with eight cooperative and municipal power distributors in Tennessee, Mississippi, and Alabama, is field testing off-peak heat storage systems in 75 Valley residences. TPI central ceramic, Megatherm pressurized water, and OEM Products, Inc. eutectic salt systems are being tested to determine consumer arcentance, cost/benefits, reliability, and load management potential.

EQUIPMENT: $\quad$ 1. TPI Corporation 21-kW and 30-kW of $f$-peak furnaces.

2. Megatherm model $\mathrm{RH}-30$ (using three of the five elements).

3. OEM Products heat battery coupled with an American Air Filters water-to-air heat pump.

CONTROL :

Time controlled by GE-IR70 time-of-day metering.

TEST

ENVIRONMENT: New and existing single-family homes.

SAMPLE: Seventy-five homes.

INCENTIVE: Special load management rates, free installation, and ownership of equipment at end of three-year program, if desired. Otherwise, equipment will be replaced with original system, or, in new homes, a heat pump system. Also, a 120-gallon, energyefficient water heater will be furnished to each. 
MONITORING: Magnetic tape meters on several points in each home.

INTERVIEW

DATE :

January 19, 1981.

STATUS: $\quad$ Approximately 60 units installed.

RESULTS: $\quad$ Not yet determined. 
TENNESSEE VALLEY AUTHORITY

REVISED 1980

210 Power Building

Chattanooga, Tennessee 37401

(615) 755-3591

Patricia H. Harris, Load Management Branch

SYSTEM: $\quad$ Combination Heat and Cool Storage - Residential

SUMMARY: $\quad$ Tennessee Valley Authority, in cooperation with the National Rural Electric Cooperative Association, the Middle Tennessee Electric Membership Cooperative, and Energy Utilization Systems, Inc., (EUS), conducted a test of two prululype EUS UPf-peak heating and cooling storage units in Murfreesboro, Tennessee. The purpose of ' this test was to determine cost, benefits, and ability of off-peak storage to provide the heating and cooling needs of a residence; to determine customer acceptance; and to provide a broader data base of off-peak storage for space conditioning and its potential use in load management.

EQUIPMENT: The heating and cooling storage system consists of a fourcomponent group:

(a) outside coil and fan

(b) duct coil

(r.) an assemhly ronsisting of the compreseor, condenser, chiller, and control package

(d) a buried 500-gallon insulated tank An air/water-to-water heat pump is used to transfer heat to the house.

CUNTRUL: The control package of the EUS unit consists of temperature sensors, relays, and pumps that operate in conjunction with the time-of-day meter provided by the Tennessee Valley Nuthority and Middle Tennessee Electric Membership Cuoperdtive. The-control package continually selects the optimal 
operating mode for the system while ensuring the minimum energy usage during the on-peak periods, providing economy for the homeowner and load management for the utility. The homeowner was charged at a reduced electric rate for the off-peak time-of-day use.

SAMPLE: $\quad$ Two residences.

INCENTIVE: The customers in this demonstration were billed under an experimental Tennessee Valley Authority time-of-day rate. A.t the end of the test period, the units were replaced with standard heat pumps.

INTERVIEW

DATE:

Apri1 28, 1980.

STATUS: $\quad$ Test terminated; final report being prepared.

RESULTS: Unsatisfactory.

REMARKS: The two participants involved seemed to appreciate the novelty of this equipment; however, repeated mechanical breakdowns resulted in participant dissatisfaction. Consumer complaints led to an agreement between all parties to terminate the test. 
VIRGINIA ELECTRIC AND POWER COMPANY

REVISED 1980

700 East Frankl in Street

Richmond, Virginia 23261

(804) $771-3440$

Don G. Virgin, Supervisor, HVAC Applications

SYSTEM: $\quad$ Combination Heat and Cool Storage - Commercial

SUMMARY: In an 18,500-square-foot, newly constructed Virginia Electric and Power Company district office and storeroom building, a heat pump will heat water off-peak in winter for space heating, and cool water off-peak in summer for air conditioning. Heated or cooled waler is slured in three 10,000-galion tanks. Supplemental electric resistance heat and a bank of solar panels are provided. objective is to reduce energy use by $15 \%$.

EQUIPMENT: Two 15-ton heat pumps. Three 10,000-gallon tanks. 740 square feet of solar panels. Pumps and piping. Control thermostats.

CONTROL: Time switches and thermostats.

TEST

ENVIRONMENT: $\quad 11,300$-square-foot office facility. 7,200-square-foot storeroom in eastern Henrico County.

SAMPLE: $\quad$ One commercial building.

INCENTIVE: Demand charge reduction.

MONITORING: Magnetic tape metering of energy use of the system and the buildings; indoor and outdoor air temperatures and humidity; Btu meter on solar input; Btu meters on cooling and heating output. 
INTERVIEW

DATE:

STATUS:

RESULTS:
August 18, 1980.

Data acquisition to begin for the 1980-81 season.

Not yet determined. 
Don G. Virgin, Supervisor, HVAC Applications

SYSTEM: $\quad$ Combination Heat and Cool Storage - Residential

SUMMARY: $\quad$ Heat and cool storage in 40 newly constructed homes will be tested, using Megatherm pressurized water units for off-peak winter heat storage and Carrier (Girton) ice storage system for off-peak summer air conditioning. Heat for hot water will be reclaimed during the air conditioning season. 40 new control homes will be equipped with conventional heat pumps only. $\Lambda 11$ homes will be instrumented to collect load research data, and six test homes will be instrumented for additional device-specific data. Storage control will be through leased telephone lines.

EQUIPMENT: Megatherm 210-gallon $50 \mathrm{psi} 280^{\circ} \mathrm{F}$ heat storage units, Carrier heat pump, Girton ice storage bin.

CONTROL: $\quad$ By leased telephone lines using a telephone signal, generated by a system control and data acquisition (SCADA) computer, to remote terminal units in 15 of the homes. The other homes will be interconnected with those 15 .

TEST

ENVIRONMENT:. 40 new homes, 1-story and 2-story, 1,400 to 2,000 square feet.' Heating degree-days--3,939; heating design temperature-- $10^{\circ} \mathrm{F}$; cooling degree-days- $-1,353$; cooling desiqn temperature- $-95^{\circ} \mathrm{F}$.

SAMPLE: $\quad 40$ new homes plus 40 new or existing comparable control group homes. 
$1-127$

INCENTIVE: $\quad$ Credit on utility bill of $\$ 30.00$ per month.

MONITORING: Magnetic tape metering to collect load research data on all homes, plus temperature and energy use data on equipment in six homes.

INTER V LEW

DATE: $\quad$ August 19, 1980.

STATUS: 25 test homes occupied. Planning to begin data acquisition for 1980-81 heating season.

RESULTS: $\quad$ Not yet determined. 


\subsection{SPECIAL THERMAL STORAGE PROJECTS}

\section{Technical Characteristics}

The nine projects included in this section can be placed into three subcategories. They are:

- Comparative analysis of two or more TES systems

- The use of unique storage media

- The use of a non-pressurized water tank as a storage rescrvoir

Four utilities - Niagara Mohawk Power Corporation, Northeast Utilities Service Company, Pacific Gas and Electric Company, and Tennessee Valley Authority - are involved in comparative analys is projects. Niagara Mohawk Power Corporation has installed an in-ground heat storage system, a ceramic brick storage system, a pressurized water heat storage system, a heat pump-based water storage system, and a conventional electric resistance heating system. These systems will be operated throughout 1982 for comparison. Northeast Utilities Service Company is involved in a project comparing water heat storage, solar-assisted water heat storage, ceramic heat storage, and conventional oil heating, all for use as back-up systems for heat pumps. Pacific Gas and Electric Company is conducting a laboratory comparison of various ice cool storage systems. Tennessee Valley Authority is installing and will test ceramic heat storage systems, pressurized water heat storage systems, and eutectic salts heat storage systems.

Three utilities - Tampa Electric Company, Long Island Lighting Company, and Detroit Edison - are testing storage air conditioning systems using unique storage media. Both Tampa Electric Company and Long Island Lighting Company are testing the concept of storage utilizing eutectic salts, while Detroit Edison is using a concrete wall as a storage reservoir. 
Two utilities - Crow Wing Co-op Power and Light, and Public Service Company of Indiana - are testing non-pressurized water heat storage systems.

Manufactured Equipment

The systems represented in this section are either custom designed, new concept prototypes, or have been described in previous sections. Brief descriptions of the custom designed and specialized prototype systems can be found in the individual project summaries. 
THIS PAGE

\section{WAS INTENTIONALLY LEFT BLANK}


Table 1-19

Special Thermal Storage Projects Sumary

\begin{tabular}{|c|c|c|c|c|c|c|c|c|c|}
\hline & & & & & & & & & \\
\hline $\begin{array}{l}\quad \text { Utilitity } \\
\text { Crow wing coop power and } \\
\text { Light Company }\end{array}$ & $\begin{array}{l}\frac{\text { Contact }}{\text { Carl Anderson, Manager, }} \\
\text { Pul inc Relations } \\
\text { (218) } 829-2827\end{array}$ & 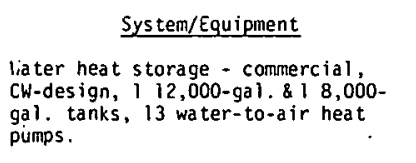 & $\begin{array}{l}\text { Control } \\
\text { Time switch and } \\
\text { themoststats } \\
\text { (radio later) }\end{array}$ & $\begin{array}{l}\quad \text { Sample } \\
35,000 \text { sq. ft. } \\
\text { copo office } \\
\text { building }\end{array}$ & Too rate & $\begin{array}{l}\frac{\text { Monitoring }}{\text { Too meter only }} \\
\text { on }\end{array}$ & 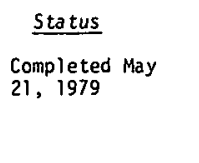 & $\begin{array}{l}\text { Results/Remarks } \\
\text { Not yet determined. }\end{array}$ & $\begin{array}{l}\text { Contact Date } \\
\text { July 20, } 1979\end{array}$ \\
\hline Detroit Edison Company & 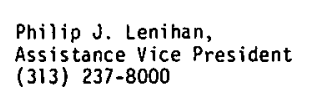 & 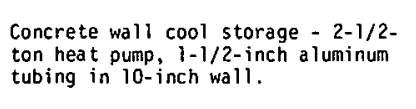 & Time switch & 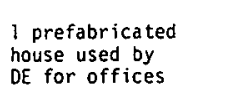 & None & Magnetic tape on temperature & Test completed & $\begin{array}{l}\text { Project completed. Not } \\
\text { economically attractive. }\end{array}$ & April 22, 1980 \\
\hline Long Island Lighting Company & 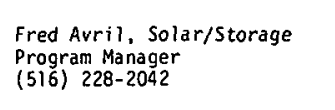 & $\begin{array}{l}\text { Eutectic salts cool storage - } \\
\text { Chus }\end{array}$ & Time switch & 1 house & $\begin{array}{l}\text { Free a air conditioning } \\
\text { system }\end{array}$ & $\begin{array}{l}\text { Magnetic tape on } 24 \\
\text { temperature points }\end{array}$ & Test continuing & Not yet determined & October 30, 1980 \\
\hline $\begin{array}{l}\text { Miagora atohank Poner } \\
\text { Corropartion }\end{array}$ & 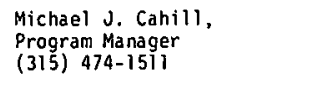 & 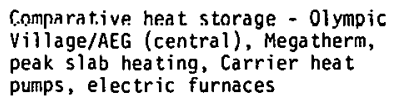 & 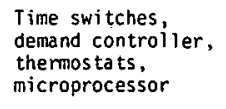 & 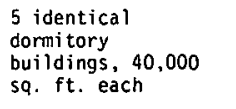 & Equi iment furni ished & 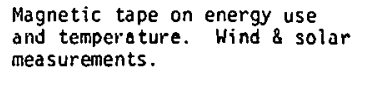 & $\begin{array}{l}\text { Consstruct ted } \\
\text { completed }\end{array}$ & 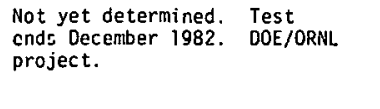 & July 3, 1980 \\
\hline $\begin{array}{l}\text { Northeast Utilities Service } \\
\text { Company }\end{array}$ & $\begin{array}{l}\text { Ear Ie laylor, Manager, } \\
\text { consumer Research } \\
(203) 666-6911)\end{array}$ & 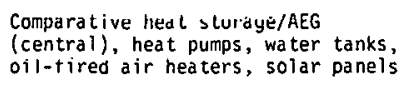 & $\begin{array}{l}\text { Time switch and } \\
\text { therersos tats }\end{array}$ & $\begin{array}{l}\text { ( houscs } \\
\text { (separate systens) }\end{array}$ & 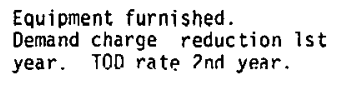 & $\begin{array}{l}\text { Magnetic tape on energy use } \\
\text { ann temperature }\end{array}$ & Test continuing & 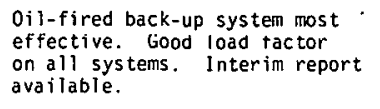 & August 14, 1980 \\
\hline $\begin{array}{l}\text { Pacific Gas and Electric } \\
\text { Company }\end{array}$ & $\begin{array}{l}\text { R.M. Mertz; Manager, Energy } \\
\text { consservation \& Services } \\
(415) \text { 781-4211) }\end{array}$ & 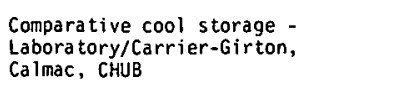 & $\begin{array}{l}\text { Time switch and } \\
\text { thernostats }\end{array}$ & N/A & $\mathrm{N} / \mathrm{A}$ & $\begin{array}{l}\text { Extensive labora tory } \\
\text { isstrumentatation }\end{array}$ & Test continuing & $\begin{array}{l}\text { 1978 results available. } \\
\text { oiffrerences in ef ficiency } \\
\text { found. }\end{array}$ & September 18,1980 \\
\hline $\begin{array}{l}\text { Public Service Company } \\
\text { of Indiana }\end{array}$ & $\begin{array}{l}\text { C.E. Foggatt, Manager } \\
\text { of Reserch } \\
\text { (317) 899-9611 }\end{array}$ & $\begin{array}{l}\text { Water heat storage - residential, } \\
\text { pst des sign, } 6 \text {. L20-gal., electrric } \\
\text { water heaters. }\end{array}$ & $\begin{array}{l}\text { Time switch and } \\
\text { thermostats }\end{array}$ & 1 house & Equi imment furnished & $\begin{array}{l}\text { Magnetic topc on enerey use. } \\
\text { Strivip haret on temenerature. }\end{array}$ & Test continuing & Report due in late 1980. & July 12, 1979 \\
\hline Tampa Electric Company & 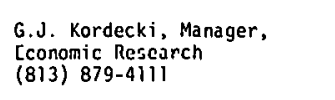 & Eutectic salts cool storage/CHUB & $\begin{array}{l}\text { Time switch and } \\
\text { thermsnstats.s }\end{array}$ & $\begin{array}{l}2 \text { houses } \\
(1 \text { employee) }\end{array}$ & $\begin{array}{l}\text { Additional cost of energy } \\
\text { paid }\end{array}$ & $\begin{array}{l}\text { Magnetic tape on energy use, } \\
\text { temperature, and hunidity }\end{array}$ & $\begin{array}{l}\text { Test starts } \\
\text { Soptember } 1 \text {, } \\
\text { 1979 }\end{array}$ & $\begin{array}{l}\text { Not yet determined. Report } \\
\text { due October } 1980 \text {. Repor }\end{array}$ & September 18, 1980 \\
\hline ennessee Valley Authority & 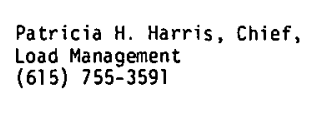 & $\begin{array}{l}\text { TPl Megastherm solarmatic } \\
\text { (Eutectic salt } t)\end{array}$ & Time switches & $\begin{array}{l}75 \text { houses in } \\
\text { Trenesesee, } \\
\text { Mississsippi, and } \\
\text { Alabamana }\end{array}$ & $\begin{array}{l}\text { Load management rates. } \\
\text { Free installation }\end{array}$ & $\begin{array}{l}\text { Magnetic tape on several } \\
\text { points in each house }\end{array}$ & 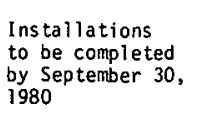 & $\begin{array}{l}\text { Comparative test of three } \\
\text { systems. }\end{array}$ & April 28, 1980 \\
\hline
\end{tabular}


LONG ISLAND LIGHTING COMPANY

NEW 1980

250 01d Country Road

Mineola, New York 11501

(516) 228-2042

Fred Avri1, Solar/Storage Program Manager

SYSTEM:

Eutectic Salts Cool Storage - Residential

SUMMARY:

In a project jointly funded by New York State Energy Research and Development Authority, Oak Ridge National Laboratory, and Long Island Lighting Company, a cool storage system designed and built by the University of Delaware has been installed in a house in Melville, Long Island, New York. Debugging and instrumentation installation was completed in September 1980 so data collection will extend through the 1981 summer.

EQUIPMENT: University of Delaware CHUB storage bundles mounted on racks in a polyurethane, insulated, 125-cubic-foot tank. The storage is sodium sulfate decahydrate-based salt hydrate with phase change in the range of $45^{\circ} \mathrm{F}$ to $57^{\circ} \mathrm{F}$. A 1-1/2-ton air conditioning compressor.

CONTROL: $\quad$ Clock switches.

TEST

ENVIRONMENT: A 1700-s.quare-foot employee home with an existing warm air duct system.

SAMPLE: $\quad$ One house requiring $2-1 / 2$ tons of cooling.

INCENTIVE: $\quad$ A free air conditioning system.

MONITORING: $\quad$ Twenty-four thermocouples on ducts, CHUB bin, outside air, house air; humidistat with magnetic tape recording. 
INTERV IEW

DATE:

October 30, 1980.

STATUS:

In service. Test will end in fall 1981.

RESULTS: $\quad$ Not yet available.

REMARKS: Some start-up problems were encountered, particularly in lowering the bin temperature to the $50^{\circ} \mathrm{F}$ objective. 
NIAGARA MOHAWK POWER CORPORATION

300 Erie Boulevard West

Syracuse, New York 13202

REVISED 1980

(315) 474-1511

Michae1 J. Cahi11, Program Manager - R \& D

SYSTEM: $\quad$ Comparative Heat Storage - 01ympic Village

SUMMARY: $\quad$ The demonstration of various customer load management techniques in a test configuration of five identical buildings presents a unique opportunity to develop a generic data base. Various thermal energ.y storage systems will be employed in the five buildings. Each of the different systems will be tested against the performance of an electric resistance system. The test period will extend through the end of 1982. The purpose of the demonstration is to determine the magnitude of controllable loads, the most economical and efficient means of control, and to collect comprehensive data on TES systems and operation. This will facilitate utility evaluation of preferred systems and control models, which might achieve desired modification of generation, transmission, and distribution load profiles.

EQUIPMENT: Building E: Slab Heating on Grade divided into ten circuits, ranging from $22 \mathrm{~kW}$ to $33 \mathrm{~kW}$. The Peak Suspension Control, Ltd. system operates at approximately 24 volts and is regulated by a local controlling device.

Building F: Eight AEG Ceramic Brick Storage Furnaces of $48 \mathrm{~kW}$ each, designed to charge in less than eight hours, are installed. The storage medium can be charged to temperatures as high as $1,450^{\circ} \mathrm{F}$. Air is delivered to the heated space and regulated at $130^{\circ} \mathrm{F}$, hy means of thermostatically-controlled dampers.

Building G: Eight Megatherm Pressurized Hot Water Storage 
Systems of $36 \mathrm{~kW}$ each, are designed to provide ten hours of discharge daily. The storage temperature can reach $280^{\circ} \mathrm{F}$ at $50 \mathrm{psi}$. A secondary water coil is controlled by a local controller and transfers heat to a duct coil in a standard air system.

Building $H:$ Four fifteen-ton Carrier Heat Pumps with Water Storage will operate air-to-air, air-to-water, water-to-air, or water-to-water, as determined by a local controller. Each system also has an electric boiler that can provide off-peak heated water, if needed, for some of the test modes.

Building J: A Conventional System consisting of 22-kW electric furnaces.

CONTROL: $\quad$ Each system has its own local controller as follows:

Building E: Demand controller and stabilizer, slab thermostat, and space thermostat. The demand controller on/off signal indicates whether or not the slab will heat. Space and slab temperatures determine the charging requirement. Building F: Outside thermostat, space thermostat, and utility signal or clock. When an on signal is received, the system reads the outside temperature and determines the required charge. The space thermostat controls dampers that regulate the proper mix and volume of air.

Building G: Pressure, temperature, and low water controls regulate tank condition. A space thermostat initiates water circulation to the water coil and fan operation. An on/off signal is provided by the utility or a clock.

Building H: A microprocessor samples space conditions, time-of-day, storage mode priority switch, and refrigeration system parameters every three seconds. Stored hot water in a hydronic air handler mode will be sampled first, then air or water source heat pump modes. Utility or clock 
control will interface with the system, and the controller can be modified to include different signals.

TEST

ENV IRONMENT: Dormitory buildings - two-story, 320,000 cubic feet, 20,000square-foot slab on a grade. ASHRAE-75 standards. 8700 degree-days, minus $20^{\circ} \mathrm{F}$ design temperature.

SAMPLE: $\quad$ Five identical buildings. Eight similar wings in each building.

INCENTIVE: None.

MONITORING: Energy measurements include: total site, total building, TES systems, air handlers, water heaters, conventional sys tems.

Temperature measurements include: storage medium, ambient, slab, ground, and outdoor. (Weather data will include wind speed and direction, solar intensity, in addition to temperature.)

INTERV IEW

DATE:

Ju1y $3,1980$.

STATUS: $\quad$ Construction completed. Equipment check showed problems with a few of the systems. These are currently being addressed.

RESULTS: $\quad$ Not yet available. 
PACIFIC GAS AND ELECTRIC COMPANY

REV ISED 1980

77 Beale Street

San Francisco, California 94106

(415) 781-4211

R.M. Mertz, Manager, Energy Conservation and Services

SYSTEM: $\quad$ Static Ice Storage Laboratory Comparison

SUMMARY: During the summer of 1978, Pacific Gas and Electric conducted a side-by-side comparison of two different cold storage systems and a conventional air conditioning system. The test was used to determine the nverall efficiency and reliability of the two icc making systems as a prelude to final equipment selection for Pacific Gas and Electric's participation in the DOE Cold Storage Demonstration Project. This laboratory evaluation was expanded for the summer of 1979. Testing will continue through 1980 and 1981.

EQUIPMENT: The Carrier and CaImac ice storage systems and a conventional three-ton air conditioning system, each using identical compressor units, were evaluated in 1978. The Carrier/Girton, Calmac Stagc I ice bank system and the University of Delaware's CHUB energy storage system were evaluated in a similar test during the summer of 1979.

CONTROL: $\quad$ Time switches.

TEST

ENVIRONMENT: Laboratory at Pacific Gas and Electric's Department of Engineering Research, in which ambient temperature conditions are changed over a wide range. Varying tonhours of cool storage will be evaluated and the discharge rates of the respective systems will be determined.

INCENTIVE: Not applicable. 
MONITORING: Extensive laboratory instrumentation.

INTERV IEW

DATE:

September 18, 1980.

STATUS: $\quad$ Evaluation will continue during summer of 1981.

RESULTS: $\quad 1978$ evaluation results are available. 
TAMPA ELECTRIC COMPANY

REVISED 1980

P.0. Box 111

Tampa, Florida 33601

(813) $879-4111$

G.J. Kordecki, Manager, Economic Research

SYSTEM: $\quad$ Eutectic Salts Cool Storage - Residential

SUMMARY: During the summer of 1979, Tampa Electric, in conjunction with the Institute of Energy Conversion at the University of Delaware, installed storage-assisted air conditioning systems in two single-family residential living units. The systems involved cooling or charging during off-peak or nighttime periods. The conventional compressor demand is shifted from daytime to nighttime hours.

EQUIPMENT: University of Delaware CHUB storage bundles mounted on racks in a four-inch walled, urethane storage bin, of about 125 cubic feet, mounted adjacent to the air conditioning ducts. The storage material is sodium sulfate decahydratebased salt hydrate with phase change in the range of $45^{\circ} \mathrm{F}$ to $57^{\circ} \mathrm{F}$. The storage bin and a drip tank mounted in the base were designed by Tampa Electric.

CONTROL: $\quad$ Clock using varying time sequences.

TEST

ENVIRONMENT: A 2,100-square-foot employee home and a 1,900-square-foot customer's home.

SAMPLE: $\quad$ Two houses.

INCENTIVE: Tampa Electric covered additional cost of energy.

MONITORING: Two magnetic tape meters measuring interior temperature and humidity, total house $\mathrm{kWh}$, air conditioner $\mathrm{kWh}$, in and out 
duct air temperatures.

INTERV IEW

DATE:

September 18, 1980.

STATUS: $\quad$ Completed.

RESULTS: $\quad$ Report due October 1980.

REMARKS: $\quad$ Design includes partial bypass for nighttime cooling.

Test will continue for two years.

$\checkmark$ 


$$
1-142
$$

\section{THIS PAGE}

\section{WAS INTENTIONALLY LEFT BLANK}


Section 2.0

COMMUNICATION AND LOAD CONTROL

\section{Introduction}

The earliest systems of involuntary load control used time switches to interrupt service to selected loads such as water heaters. While problems occasionally developed from units gaining or losing time, the objective of load shifting was generally attained, consequently easing the need for new generation facilities. Although this simple device will continue to be used in load management schemes, it is limited by the need to anticipate appropriate fixed settings and the lack of customer control. To achieve load control with a minimum of problems, systems have been developed that make possible remote but not fixedtime shut-off, utility control of shut-off time, and, in some cases, customer control of load reduction. These systems offer the means for communicating desired load control patterns and eliminating loads according to those patterns. Further, some advanced systems can be utilized for distribution automation functions.

The basic devices for point-of-use load control are mechanical switches, such as those used in time switches and thermostats. The communication systems described above require a receiver to translate the load control information and activate the contact within the receiver switch. Several devices have been developed that add local, on-site logic to the simple switching function. Some of these are designed to interface with a remote communication system, and others are designed to operate entirely in a local site-specific or time-specific manner.

\section{Benefits of Controlling Load}

The application of C\&LC systems will fall into three general categories: 1) remote control of a load, 2) communication functions that interface with other systems or devices, and 3) automation. To evaluate the effectiveness of a load management system or device, it is necessary to examine the effectiveness of the various load management schemes in terms of $\mathrm{kW}$ demand reduction. The benefits of 
the various distribution automation (DA) functions must be examined in terms of the costs of the traditional methods of performing said functions.

This latter analysis is difficult because of several factors. Since most of the systems utilized in DA represent new technologies, there exists a very limited data base on the costs and benefits of such functions. The potential benefits of DA can also vary enormously from utifity to utility, depending upon the situation. Remote automatic meter reading, for example, is essentially valueless to a rural electric cooperative (REC) where the customer typically reads his own meter. Conversely, the value of remote meter reading could be quite high to an urban utility where manual meter reading can be expensive because of high labor costs, inaccessability of meters, etc. Other UA tunctions will hold different levels of value to different utilities. It is commonly held, however, that the benefits of DA must be considered as being incremental benefits, above and beyond those benefits derived from the load control applications of the system. In other words, a C\&LC system is rarely cost effective if viewed only in terms of DA. It is the value of load control, then, that is the key element in the economics of a C\&LC system. The incremental value of other functions, along with other factors such as limiting distribution system characteristics, limits the sophistication level or type of C\&LC system that a utility can justify.

The dollar value of controlling a $\mathrm{kW}$ of load is dependent upon several factors, including wholesale power costs, capital costs of new generation and distribution equipment, and/or operation penalties realized through the use of fuel-intensive peaking equipment. Every utility could assign a unique dollar value to this load depending upon its own costing methodology. However, the value of controlling a load in terms of coincident $\mathrm{kW}$ demand reduction ought to be apparent to any utility. While the coincident $k \dot{W}$ demand reduction potential of any particular appliance or device can vary from situation to situation, enough information has been reported by utilities to provide a range of values suitable to the purposes of this report. 
Electric Water Heater Control. The electric water heater is the appliance that has received the most attention in terms of its load deferral potential. This is due to two major reasons. First, a water heater is one of the few residential loads that is truly deferrable, in that it can generally be controlled to the point that it offers the utility some level of load relief without affecting the lifestyle of the customer. This is due to the inherent thermal storage capabilities of a water heater. Secondly, the electric water heater represents a relatively high load appliance that sees yearround use, offering potential to both winter and summer-peaking utilities.

Since the electric water heater is a deferrable load, it is usually controlled for relatively long periods of time (up to four hours in some cases) as opposed to short cycling periods. As such, the coincident $\mathrm{kW}$ demand reduction potential of an electric water heater is essentially equal to its coincident diversified demand. This assumes that the duration of peak control is within the limits of the water heater's storage capacity. Since water heater use shows only slight sensitivity to variable factors like ambient temperatures, utilities can usually place a good annual or seasonal fix on the coincident diversified water heater demand on their systems using the various methodologies of load research. Table 2-1 lists those utilities that, during the course of this survey, have reported their findings on average coincident diversified demand per water heater.

Tahle 2-1

AVERAGE COINCIDENT DIVERSIFIED DEMAND REDUCTION PER WATER HEATER

Utility

Buckeye Power

Detroit Edison

Grant Electric Cooperative

Oconto Electric Cooperative

Sumter Electric Membership Corp.

Wisconsin Electric Power Co.
Demand $(\mathrm{kW})$

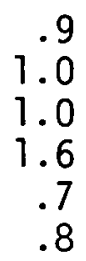


Table 2- 1 indicates that the average of the coincident diversified demands reported for electric water heaters is approximately $1 \mathrm{~kW}$. Although it is not possible to identify a potential figure for water heater control demand reduction that would be applicable to all utilities, this $1 \mathrm{~kW}$ potential does seem to represent the typical per point load reduction realized by utilities that are active in water heater control programs.

Central Air Conditioner Cyclic Control. In the past few years, the central residential air conditioner has received a lot of attention as a prime candidate for load control. It is now the second most widely controlled appliance.

An air conditioner is not really a deferrable load because it cannot be cycled off for any length of time beyond its own natural off-cycle time without some resultant degradation of comfort levels within the home. The standard method of remote air conditioner cycling involved the shut-off of the compressor via the interruption of low voltage control lines for some fixed period of time each hour. Typically, this period is 7-1/2 minutes each half-hour, which translates to fifteen minutes each hour. It is theorized that such a forced cycling scenario will result in a reduction of the normal on-time of the air conditioner compressor, thereby resulting in a lower integrated demand for the unit. The desired reduction of demand is realized through the lowering of the integrated demands of the air conditioners of the utility's system.

The limiting of these cycling times results in a degradation of comfort levels within the home in direct proportion to the amount of load relief obtained. For example, assume that a particular air conditioner with a connected load of $4 \mathrm{~kW}$ is sized such that it is operating at $100 \%$ capacity during the entire period in which the utility wishes to exercise control. At this time, the unit's integraged demand is essentially its connected load. If the utility cuts its natural on-cycle (60 minutes per hour) by $25 \%$ to 45 minutes per hour, then its integrated demand over that hour will essentially be 
reduced from $4 \mathrm{~kW}$ to $3 \mathrm{~kW}$, a resultant 1- $\mathrm{kW}$ reduction in demand. The result of this demand reduction in terms of the comfort levels of the home would be a rise of approximately $2.8^{\circ} \mathrm{C}\left(5^{\circ} \mathrm{F}\right)$, assuming an outdoor temperature of $32^{\circ} \mathrm{C}\left(90^{\circ} \mathrm{F}\right)$ and a normal indoor temperature setting of $21^{\circ} \mathrm{C}\left(70^{\circ} \mathrm{F}\right)$. If this change in temperature represents the maximum level that the customer is willing to tolerate, based on his attitude toward the utility and/or the financial incentive offered to him, then this cycling scenario represents the maximum or optimum level of acceptable control and load relief. If, on the other hand, this temperature change exceeds the maximum tolerable level, then the customer is being overcontrolled. If this change is less than the maximum tolerable level, then the customer is being undercontrolled.

Because of expected systemwide variation in customer tolerance levels and air conditioner sizing, any program which relies on control via fixed-time cycling can be expected to produce some mix of over, under, and optimum control among customers. In order to minimize customer complaints and withdrawals, it may be necessary for a utility to utilize a more conservative cycling scenario that produces less than optimal demand reduction.

One possible alternative to this time-based method of control is a temperature-based method of control. This type of cyclic control $1 \mathrm{im}-$ its air conditioner duty cycles and hence, limits integrated demands by altering duty cycles. Although this type of control might offer a utility a higher level of load control optimization, any additional benefits would have to be weighed against any additional hardware costs that might be incurred.

As mentioned previously, the tolerance level a customer may show for comfort condition degradation is a direct function of his attitude toward the utility and/or the incentive offered to him by the utility. As discusscd above, this tolcrance level is onc of the key limiting factors in the determination of the potential load relief benefits of an air conditioner control program. Two other factors which will 
determine the coincident demand reduction potential of an air conditioner control program will be the average size loads found within the system, and the coincidence factor of the residential air conditioning peak with the utility's system peak.

Table 2-2 1ists seven utilities active in air conditioner control programs, along with their reported coincident diversified demand reduction realized per point of control.

Table 2-2

AVERAGE COINCIDLNT DIVLRSITIED DLMAND RLDUCTION PER NIR CONDITIONER

Utility
Arrkansas Power and Light
College Park Electric System
Kansas Gas and Electric
Lawr'Llleville Electric Dept.
Nevada Power Co.
Sumter EMC
Camilla Electric Dept.

Demand $(\mathrm{kW})$

1.0

1.0

1.0

1.25

1.35

1.0

1.5

The average coincident demand reduction potential, shown in Table 2-2, is $1.16 \mathrm{~kW}$. Although it is not possible to identify an air conditioner control demand reduction applicable to all utilities, most utilities that are active in air conditioner control programs report reductions similar to this average figure.

Electric Heating Cyclic Control. The cyclic control of residential heating systems, including central, zoned, and heat pump systems, has lately gained the attention of utilities seeking controllable loads. The cyclic control of heating circuits or systems is constrained by the same non-deferrable load limitations as those found in cyclic control of air conditioner systems. That is, no net reduction in demand can be realized unless the system is forced to cycle off for longer durations than its own natural cycling would dictate. In the case of air conditioner control, this change in cycling results in a rise in internal temperatures. In the case of heating systems, 
such a cycling change results in a drop in internal temperatures. This poses a particular problem in terms of customer tolerance of control. As was discussed under cyclic air conditioner control, the level of comfort degradation that a customer is willing to tolerate is a key factor in determining the net potential load relief benefits that a utility could realize in a program of non-deferrable load control. Although this tolerance level would be a direct function of customer attitude toward the utility as well as the incentive offered by the utility, it is reasonable to assume that a customer would be less likely to tolerate a temperature degradation in the winter than he would in the summer. In some cases, the possibilities of heating system overcontrol also poses potential health hazards in the winter. The utilization of control by temperature as opposed to time, as discussed under air conditioner control, could help to limit some of these problems, but the incremental cost of the required additional hardware would negatively affect any resultant benefits.

Until more empirical data becomes available from the utilities presently experimenting with cyclic control of heating systems, nothing conclusive can be reported on the average of "typical" potential load reduction benefits of a space heating cyclic control program.

Irrigation Pump Control. Aside from water heaters, air conditioners and space heating systems, there are several other types of load that utilities have targeted for load control. Some of these loads are very region-specific in the sense that, while they may offer significant potential in terms of per point load relief, they do not represent loads that are common to most utilities. A significant example of this type of load is an irrigation pump. To many utilities in the mid and southwest, irrigation pumping constitutes a major component or lile lulal load. One ut1ifty, Southwest Public Power Vistrict in Nebraska, has estimated that about $85 \%$ of it.s summer peak loand is due to irrigation.

The potential benefits that a utility could expect to realize in a pump control program will depend very heavily on the relative 
deferability of these loads. Although the control of these pumps would not be expected to have any immediate and direct impact on human lifestyles, the potential of adversely affecting crop yields does exist.

The question of what actual crop reduction, if any, would result from an irrigation load control program has been approached in several studies. The summary report of the NRECA research project on irrigation load management states :

"It has not been determined whether crop yields were possibly reduced because of control or increased because of improved irrigation water management when irrigation systems were controlled. Because of the continued

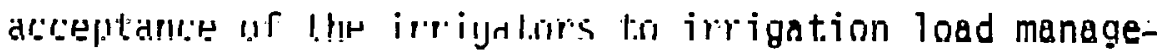
ment, no yield reductions have been assumed."

Ncbraska Public Power District has indicated that in a 1976 test at Southwest Public Power District, farmers reported that there was no significant reduction in crop yield, in spite of the control of their pumps. This was partially attributed to improved irrigation management while under load control.

In essence, what these studies have said is that, while the crop reduction potential does exist, it can be eliminated by improved water management techniques. Should any yield reduction exist, it may be compensated by the incentives offered to the farmer by the utility.

The methodology that most utilities have used in determining what levels of control will be exercised on irrigation loads (and hence, the level of potential crop reduction) is to allow the farmer to choose the level of control he is willing to tolerate. This is done by offering various rate incentives based on various levels of control.

For example, the farmer who allows the utility to control his irrigation pumps at any time will be offered the lowest rate. A farmer

Irrigation Load Management, Summary Report. Washington, D.C.: National Rural Electric Cooperative Association, January, 1978. 
who permits control on only one or two specific days of the week will pay a higher rate. The farmer who does not permit control at any time will pay the highest rate.

Thus, since irrigation does represent a conditionally deferable load, the per point potential coincident demand reduction that a utility could expect to realize from pump control would be essentially the coincident diversified demand of the pumps that the utility is able to control at any given time.

The largest known concentration of irrigation pump control is found among rural utilities in Kansas and Nebraska. At least thirteen of the REC's served by Nebraska Public Power District, for example, presently have a total of over $125 \mathrm{MW}$ of connected irrigation load under control. The coincident diversified demand reduction experienced by these utilities has been estimated to average slightly more than sixteen $\mathrm{kW}$ per point of control.

Arkansas Power and Light is another large utility actively involved in the control of irrigation loads. AP\&L's agreement with its irrigation customers is such that during periods of peak demand, one half of all controllable pumps will be off at the same time. The average rating of these pumps is $40 \mathrm{hp}$ and since they show virtually no diversity on the hottest summer days, AP\&L customers realize approximately $15 \mathrm{~kW}$ in load relief per point of control.

Another utility involved in this type of control is Sulphur Springs Electric Coop. (SSV) in Wilcox, Arizona. SSV presently reports $10,000 \mathrm{hp}$ under control with a coincident diversified demand reduction average of $15 \mathrm{~kW}$ per point of control.

Control of Other Loads. In addition to residential water heaters, air conditioners and space heating systems, and agricultural irrigation pumps, several other types of loads are being controlled by electric utilities. Most air conditioner control programs, for example, involve some small mix of commercial air conditioners along with 
residential units. While these commercial units offer proportionally higher demand reduction potentials, they, with few exceptions, represent only a small percentage of the total number of points of control in most programs.

Other loads that are being controlled by utilities include swimming pool pumps, potato warehouses, tobacco barns, and various commercial and industrial loads. Many of these loads are very region- or utility-specific. Because of the limited research conducted in these areas, little can be reported on the value of controlling loads other than the types previously discussed.

\section{C\&LC Projects Summary}

A number of electric utilitics in tlie Uniled Statés -- investor-owned, municipal, and cooperative -- are conducting a variety of communication and load control projects using a variety of remotc communication systems and/or on-site devices.

One hundred fifty-eight such:projects, involving 127 electric utilities, are described in the following sections. Although most of these projects are demonstrative in nature, 66 projects represent a systenwide or near systemwide commitment on the part of the utility to implement load management.

The more significant large-scale commitments include: Arkansas Power and Light's systemwide radio coverage which is available to 125,000 air conditioning customers; Buckeye Power's present radio control of 45,500 water heaters; Cobb Electric Membership Corporation's radio control of 13,000 air conditioners and. 1,300 water heaters; Colquitt Electric Membership Corporation's combination radio and powerline carrier control of 8,000 air conditioners and water heaters; Detroit Edison's long established, territory-wide radio control of 200,000 water heaters; the Greenville Utilities Commission's radio control of 4,000 water heaters and 3,500 air conditioners; Lumbee River Electric Membership Corporation's radio control of 6,000 water heaters and 2,000 air conditoners; Minnkota Power Cooperative's 
territory-wide ripple system which is expected to control various loads of 20,000 consumers by 1980; 21 of the 33 rural electric associations, represented by Nebraska Rural Electric Association, have implemented irrigation pump control utilizing radio, ripple, and local control systems; The Sacramento Municipal Utility district radio control of 6,250 air conditioners; Southern California Edison's ultimate control over 23,000 customers' water heaters and air conditioners using a combination radio and power line carrier system; The Wabash Valley Power Association commitment to the radio control of 20,000 water heaters; Walton Electric Membership Corporation's radio control of 5,000 air conditioners and water heaters; the Albany, Georgia Water, Gas \& Light Commission radio/power line carrier project controlling over 4,400 air conditioners and water heaters; and Wisconsin Electric Power's systemwide power line carrier expected to eventually control 150,000 water heaters.

In total, these 158 C\&LC projects involve the present or planned controi of an estimated 560,000 water heaters, 216,000 air conditioners, and 24,000 miscellaneous loads, including irrigation pumps and space heating systems.

A variety of incentives has been developed by the utilities to persuade consumers to accept C\&LC during test months or on a continuing basis. These include: special filed temporary or permanent, seasonal or annual rates designated "experimental," "seasonal," "time-of-day," or "load control"; unfiled special contracts; and cash refunds or gift certificates. The special rates take different forms, including residential demand rates, rate per kilowatthour differentials, and monthly bill cash credits based on connected horsepower or kilowatts, or number of appliances controlled. Where the functions performed are meter reading or local control simulation only, incentives are not usually offered since consumer inconvenience is minimal. In many instances of actual load control, no 
incentives are offered and utilities report excellent customer cooperation. Incentive for control of commercial and industrial loads is generally the prospective reduction in monthly billing demands; although, in some instances, incentive credits or special rates are offered.

In the course of this survey, a number of companies inactive in load control indicated that their staffs and managements were studying the possibility of engaging in a C\&LC test program. Other utilities are waiting for more reliable second- or third-generation equipment to become available or to hear the results of neighboring utility projects before embarking on tests of their own. Several utilities, now testing one system or a particular manufacturer's equipment, intimated that they were likely to conduct new tests with alternative systems or a similar system supplied by another manufacturer. Thus, it is likely that utility activity in load control will continue to expand during the next several years.

The C\&LC projects described herein are as follows:

$\begin{array}{lr}\text { Radio } & 68 \text { projects } \\ \text { Ripple } & 77 \text { prnjerts } \\ \text { Power Line Carrier } & 22 \text { projects } \\ \text { Combination Radio and } & \\ \text { Power Line Carrier } & 18 \text { projects } \\ \text { Telephone } & 5 \text { projects } \\ \text { Local Controllers } & 15 \text { projects } \\ \text { Miscellaneous } & 8 \text { projects }\end{array}$

A]though these 158 projects are being managed by 126 utilities, a number of additional local utilities participate in the geographically widespread projects sponsored by holding company service corporations or generation and transmission cooperatives. 
The following key is used to identify the type of C\&LC system used by the listed utility in its project(s):

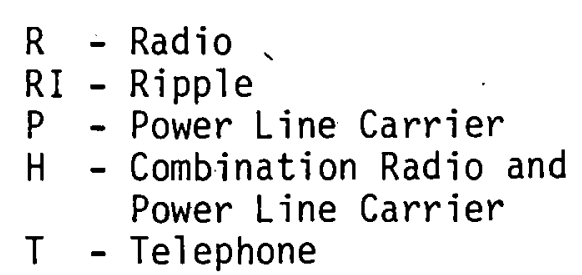

Utility

Adams-Marquette Electric Coop Ade T. Light Department Albany Water, Gas \& Light Comm. Alfalfa Electric Coop Allegheny Electric Coop, Inc. American Electric Power Appalachian Electric Coop Arizona Public Service Co. Arkansas Power \& Light Co. Ayden water and Light Dept. Barnesville Electric Dept. Black River Electric Coop Boston Edisón Co. Buckeye Power, Inc.

City of Burbank Camilia Electric Dept.

Carolina Power and Light Co. Central Illinnis Light Co. Central Kansas Power Co. Central, Maine Power Co. Central Vermont Public Service Cobb Electric Membership Corp.

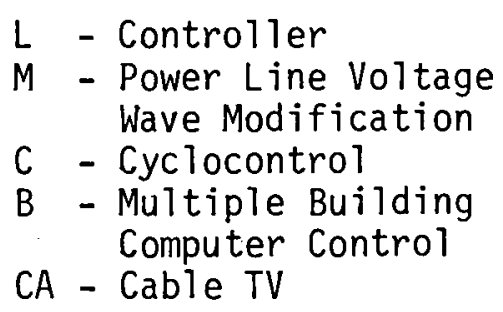

Type(s) of C\&LC

Page(s)

$\mathrm{R}$

2-27

2-129.

$\mathrm{L}$

2-161

$\mathrm{R}$

$2-27$

$\mathrm{R}, \mathrm{P}, \mathrm{H}$

$2-27,105,129$

$H$

2-129

$\mathrm{L}$

2-161

R

$2-27,35$

$\mathrm{H}$

2-129

2-129

$\mathrm{R}, \mathrm{L}$

$2-27,161$

2-105

$2-27,31$

2-173, 175

B

2-129

H

$R, P$

$2-27,105$

$R$

2-27

2-27

2-27

2-29

RI

$2-27,40$ 


\begin{tabular}{|c|c|c|}
\hline Utility & Type (s) of C\&LC & Page(s) \\
\hline College Park Electric System & R & $2-27$ \\
\hline Colquitt Electric Membership Corp. & $\mathrm{H}$ & $2-129,131$ \\
\hline Commonwealth Edison & $\mathrm{P}$ & $2-105$ \\
\hline Consolidated Edison & RI & $2-79,83$ \\
\hline Consumers Power & RI & $2-79$ \\
\hline Conway Corporation & $\mathrm{R}$ & $2-27$ \\
\hline Dayton Power and Light Co. & $\mathrm{R}$ & $2-27$ \\
\hline Delmarva Power and Light Co. & $\mathrm{P}$ & $2-105$ \\
\hline Detroit Edison Company & $\mathrm{R}$ & $2-27,42$ \\
\hline Dixie \& Escalante Rural Electric Conp & $\mathrm{R}$ & $2-27$ \\
\hline Douglás Water \& Light Uepartment & $R$ & $2-27$ \\
\hline Duke. Pnwer & $R, P$ & $2-27,105$ \\
\hline East Point Municipal Electric Dept. & $\mathrm{R}$ & $2-29$ \\
\hline Fairmont Public Utilities Commission & RI & $2-79$ \\
\hline Farmers Electric Cooperative & $\mathrm{R}$ & $2-29$ \\
\hline $\begin{array}{l}\text { Fitzgerald Water, Light \& Bond } \\
\text { Commission }\end{array}$ & $\mathrm{R}$ & $2-29$ \\
\hline Florida Power Corporation & $R, P, T$ & $2-29,105,143$ \\
\hline Fort Valley Utilities Commission & $\mathrm{RI}$ & $2-79$ \\
\hline City of Forsyth & H & $2-129$ \\
\hline Georgia Power Company & $R, R I$ & $2-29,44,79$ \\
\hline Grant Electric Cooperative & RI & $2-79$ \\
\hline Green Mountain Power & RI & $2-79,85$ \\
\hline Greenville Utilities Commission & $\mathrm{R}$ & $2-29,46$ \\
\hline Griffin Electric Department & $\mathrm{R}$ & $2-29$ \\
\hline Gulf Power Company & $L$ & $2-161$ \\
\hline Gulf States Utilities & $\mathrm{R}$ & $2-29$ \\
\hline Highline Electric Association & $\mathrm{R}$ & $2-29,48$ \\
\hline Independence Power \& Light Dept. & $P$ & $2-105$ \\
\hline Intermountain Rural Electric Assoc. & $\mathrm{L}$ & $2-167,163$ \\
\hline Kansas City Power and Light & $\mathrm{R}$ & $2-29$ \\
\hline Kansas Electric Cooperative, Inc. & $R, L$ & $2-29,173$ \\
\hline Kansas Gas \& Electric Company & $\mathrm{R}$ & $2-29,50$ \\
\hline
\end{tabular}


Utility.

Type(s) of C\&LC

Page(s)

Lakeland Dept. of Electric and Water Utilities

$H$

Lumbee River Electric Coop

Marietta Board of Lights \& Water Works

Marshall Municipal Utilities

Minnkota Power

Mississippi Power \& Light Co.

Missouri Power \& Light Co.

Monroe Water, Light \& Gas Co.

Moultrie Water \& Light Department

Nebraska Public Power District

Nebraska Rural Electric Association

Nevada Power Company

New England Electric System

New Hampshire Electric Cooperative

New Orleans Public Service

New York State Electric \& Gas

Newnan Water \& Light Commission

Norcross Municipal Light Department

North Arkansas Electric Coop

North Attleboro Municipal Electric Light Department

North Little Rock Electric Dept.

Northern States Power

Northeast Utilities Service Co.

Oconto Electric Cooperative

Ohio Edison Company

0klahoma Gas \& Electric Company

Omaha Public Power District

Osage Municipal Light \& Power Dept.
$\mathrm{R}$

$\mathrm{R}$

$\mathrm{R}$

$2-29$

2-29

$2-129,132$

$2-29,52$

RI

$2-79$

$2-79$

$2-79,87$

2-29

$2-29,173,177$

$2-173,178$

2-129

$2-29,54$

$2-173,180$

2-29

$2-173,182$

2-129

2-79

2-161

$2-129$

2-79

2-29

$2-31$

2-31

$2-79,105,161$

2-105

2-31

$2-|6|$

$2-31,161$

2-143, 145, 147

2-129 


\begin{tabular}{|c|c|c|}
\hline Utility & Type(s) of C\&LC & Page (s) \\
\hline Otter Tail Power Company & $\mathrm{R}$ & $2-31$ \\
\hline Pacific Gas \& Electric & $R, P, T, L$ & $\begin{array}{l}2-31,56,105,109,111, \\
143,150,161,165\end{array}$ \\
\hline Petit Jean Electric Coop & $R$ & $2-31$ \\
\hline Philadelphia Electric Company & $P$ & $2-105$ \\
\hline The Potomac Edison Company & L & $2-161,167$ \\
\hline Potomac Electric Power Company & $R, L$ & $2-31,161$ \\
\hline Prince William Electric Coop & $\mathrm{R}$ & $2-31,58$ \\
\hline Public Service Electric \& Gas & RI & $2-79,90$ \\
\hline Rappahannock Electric Cooperative & $\mathrm{R}$ & $2-31$ \\
\hline Redding [lectric Uti]ity & $H$ & $2-129$ \\
\hline Riceland Electric Coop & $\mathrm{R}$. & $2-31$ \\
\hline Rural Electric Company & $\mathrm{R}$ & $2-31$ \\
\hline Sacramento Municipal Utility District & $\mathrm{R}$ & $2-31$ \\
\hline St. Joseph Light \& Power Company & $P$ & $2-105$ \\
\hline San Diego Gas \& Electric Company & $R, P$ & $2-31,60,61,105,112$ \\
\hline Shenandoah Valley Electric Coop & $\mathrm{R}$ & $2-31$ \\
\hline Snapping Shoals EMC & $P$ & $2-105$ \\
\hline South Carolina Electric \& Gas Co. & $H$ & $2-129$ \\
\hline Southern California Edison Company & $R, H, T, L, B$ & $\begin{array}{l}2-31,62,129,134,136 \\
143,151,161,173,184\end{array}$ \\
\hline Springfield City Utilities & $P$ & $2-105$ \\
\hline Sulphur Springs Valley Electric Coop & $R$ & $2-31$ \\
\hline Sumter Electric Membership Corp. & R & $2-31$ \\
\hline Sylacauga Utilities Board & $H$ & $2-129$ \\
\hline Tennessee Valley Authority & $R, P, L$ & $\begin{array}{l}2-33,64,66,107,114 \\
161,169\end{array}$ \\
\hline Thief River Falls Water \& Light Dept. & RI & $2-79$ \\
\hline Thomasville Water \& Light Dept. & $\mathrm{R}$ & $2-33$ \\
\hline Thumb Electric Cooperative & $\mathrm{R}$ & $2-33$ \\
\hline Tri-County Electric Membership Corp. & C & $2-173$ \\
\hline The United Illuminating Company & $P$ & $2-107$ \\
\hline United Power Association & RII & $\ddot{z}-\bar{T} \dot{y}, y \ddot{z}$ \\
\hline Utah Power and Light & $R, R I$ & $2-33,79$ \\
\hline Verendrye Electric Coop, Inc. & $P$ & $.2-107$ \\
\hline Vernon Electric Cooperative & RI & $2-79,93$ \\
\hline
\end{tabular}


Utility

Virginia Electric \& Power Company Wabash Valley Power Association

Walton Electric Membership Coop

Washington Electric Utility

Waushara Electric Cooperative

West Memphis Utility Department

Wisconsin Electric Power Company

Wisconsin Public Service Corp. -

York County Rural Public Power District

Y-W Electric Association, Inc.
Type (s) of C\&LC

$R, R I, P$

$\mathrm{R}$

$\mathrm{R}$

$H$

- $\mathrm{R}$

RI

$P$

$P$

$R$

$R$
Page(s)

$2-33,81,95,107,116$

$2-33,68$

2-33

$2-129$

2-33

2-87', 97

2-107, 117

2-107, 119

2-33

2-33 


\subsection{RADIO}

\section{Technical Characteristics}

The FM radio C\&LC system is the most widely used C\&LC system in the United States. Systems presently available are capable of unidirectional (utility to control point) communications only. The relatively low cost, simplicity, and proven high reliability of FM radio systems have gained them wide acceptance among utilities. The simplicity of a radio system also imposes limitations on it. Terrain and man-made objects reduce radio signal propagation to an effective range of 5 to 25 miles ( 8 to $40 \mathrm{~km}$ ) for a 300-watt transmitter. This power iimitation, imposed by Federal Communications Commission (FCC) regulations, can be circumvented by adding remote transmitters with an uverlapping signal range, but at a higher cost.

A radio C\&LC system functions in the following manner:

- Utility system data is fed into a computer-based central controller that analyzes the data and compares it to utility setpoint parameters such as load leve1, temperature level, rate of load increase, or any other pertinent information. When the analyzed input data for one of these parameters exceeds the setpoint, the controller will issue a command to the transmitter via a telemetry link.

- The command received at the transmitter is translated into a coded tone signal by a tone encoder. A typical single tone sequence radio system may utilize ten different tones to control ten different load groups. Typical tones have frequencies in the range of 100 to $3,000 \mathrm{~Hz}$. (Some radio systems have the ability to send out a multiple tone sequence, which gives them a much greater addressing capability.) The desired tone is then broadcast using an FM transmitter operating in an FCC-approved frequency band $(48,138,154,174$, or $450 \mathrm{MHz}$ ) with a maximum power of 300 watts.

- The tone encoded signal is received by the radio switch located at the point of control. This radio switch consists of an antenna, receiver, tone decoder, and electro-mechanical relay device. The 
FM receiver detects all tone-encoded signals transmitted on the frequency to which it is tuned, and compares the incoming tones to a preprogrammed tone in the decoder. The programmed tone is typically controlled by means of a vibrating reed, but may be crystal or digitally controlled. The tone decoder will not signal the relay unless it detects the proper tone or proper sequence of tones. Upon receiving the proper command, the relay performs the desired load control function, which is usually the shut-off of a designated load or, in some cases, the initiation of control by a local controller. The relay is usually designed to restore the load after about seven minutes unless it receives a follow-up command. Some systems use a latching type relay which will not restore the load until the receiver is signaled to do so.

FM tone encoding transmission and reception technology, as utilized for radio C\&LC equipment, has been widely used for quite a few years (for police, fire, aircraft, taxi, and amateur radio communications) and has therefore been proven to be a highly reliable technology.

There are variations to the previously described radio system operations. Controlling signals may consist of one, two, or more audio tones. The radio system may use a digital address system instead of tones. A radio receiver switch may be capable of more than one function. Bidirectional capability may become commercially available in the near future, and would allow the central controller to receive data from the points of control, as well as control them.

Of the more than 500,000 radio switches in use today, the majority are used to control electric water heaters. The second largest application is the control of central air conditioners, followed by control of irrigation pumps, electric heating circuits, and other loads.

Control of on-site local logic controllers, energy storage devices, dual fuel systems, register meter shifting, peak alerting devices, and distribution automation functions are all possible applications of radio C\&LC systems. Its relatively low per point cost, high reliability, and simplicity will allow the radio C\&LC system to continue to gain wider 
acceptance in the load management environment.

\section{System Costs}

The per-point cost a utility might expect to incur for a radio control system is dependent upon several variables, including, but not limited to, size of system, delivery requirements, number of transmitter, redundancy of systems, sophistication of central control, telemetry costs, type of switch, and local labor rates.

As a first step in determining a valid per-point cost, quotations on equipment costs were acquired from several major manufacturers.

Manufacturer A - The basic single-function receiver switch with standard address capability sells for $\$ 65$ to $\$ 75$, depending upon quantity ordered and delivery schedules required. Multifunction switches raise the cost by $\$ 20$ per function. Switches with increased address capacity (20-tone vs. 10-tone) cost $\$ 15$ more. The basic 300-watt transmitter costs $\$ 5,000$, plus approximately $\$ 1,000$ for antenna and coaxial cable. Transmitting towers average $\$ 10-\$ 15$ per foot ( $\$ 33-\$ 49$ per meter), depending upon type of tower and height required. The cost of a central control microprocessor is $\$ 25,000$, plus approximately $\$ 5,000$ for software,

Manufacturer $B$ - The basic single-function receiver switch with a 30-amp relay costs $\$ 70$. A dual-function switch with two-tone address costs $\$ 95$. A two-tone receiver with a mechanical latching relay, counter, and indicating lights, sells for $\$ 170$ and is typically used for controlling irrigation pumps.

Manufacturer C - A single-function receiver switch with a 30-amp relay costs $\$ 71.40$ to $\$ 83.30$, depending upon the quantity ordered. An optional counter for the above switch adds approximately $\$ 11$ to the cost. A power control receiver with two-tone address and a latching relay costs $\$ 160$ to $\$ 180$.

Manufacturer $D$ - The costs for digitally addressable receiver switches are $\$ 100$ for the single-function and $\$ 125$ for the double-function models. Central control message generators range from $\$ 7,000$ to $\$ 15,000$. 
Manufacturer $E$ - The costs for receiver switches are $\$ 75$ for the 2-ampere power output model and $\$ 90$ for the 30 -ampere output model. Both models have an inherent two-function capability. Costs for a central control system range from $\$ 25,000$ to $\$ 40,000$. Costs for each radio transmitter and antenna range from $\$ 3,000$ to $\$ 10,000$, depending upon frequency, output power, and construction conditions.

As stated earlier, radio switches may be single- or multifunction (one or more switching functions), may have advanced address capacity (up to 20 variable address tones or a digitally-based addressing system) or may have specialized switching apparatus (latching) with counters and lights. The specialized types of switches have advantages in certain applications, but the overwhelming majority of switches in use today are the singlefunction type with the standard address capability. The average cost of this type of receiver switch, based on manufacturer's quotations, is approximately $\$ 75$. This evaluation will concern itself chiefly, then, with the single-function switch system.

The primary consideration in determining the cost of a C\&LC system is the total installed hardware cost per point of control. This per point cost is a function of the cost of the switch, the labor cost required to install the switch, and the total installed costs of all other equipment (transmission, telemetry, and control) apportioned out according to the number of switches involved. It can be seen, then, that the larger the system, the less significant all costs other than the installed cost of the switch itself. For example, if the installed control and transmission costs of a system were $\$ 200,000$ (including costs of all other equipment), that cost would represent $\$ 20$ per switch in a 10,000-point system, $\$ 10$ per, switch in a 20,000 point system, $\$ 4$ per switch in a 50,000 -point sytem, and so on. This seemingly dramatic drop in costs ( $\$ 20$ to $\$ 4$ ) becomes less dramatic when the cost of the switch itself, along with the cost of installing the switch, is added to the total cost. If a utility pays $\$ 75$ for a receiver switch and pays an electrician $\$ 20$ to install the switch, then the total installed cost of the switch is $\$ 95$. Adding in the apportioned costs cited above, yields a total system per point cost of $\$ 115$ for a 10,000-point system and $\$ 99$ for a 50,000-point 
system. This relationship is shown graphically in Table 2-3. While the costs cited are only illustrative, Table 2-3 demonstrates that once a certain point of receiver saturation is achieved $(30,000$ points in this example), the total system per point installed cost becomes insensitive to any but the costs of the switch and its installation.

It is not possible to identify an exact per point cost of a radio system that would be applicable to any utility and any system size. It is possible, however, to identify the typical ranges of per point costs as reported by utilities, and determine from these costs an average or "typical" per point cost which may be used in a cost/benefit evaluation.

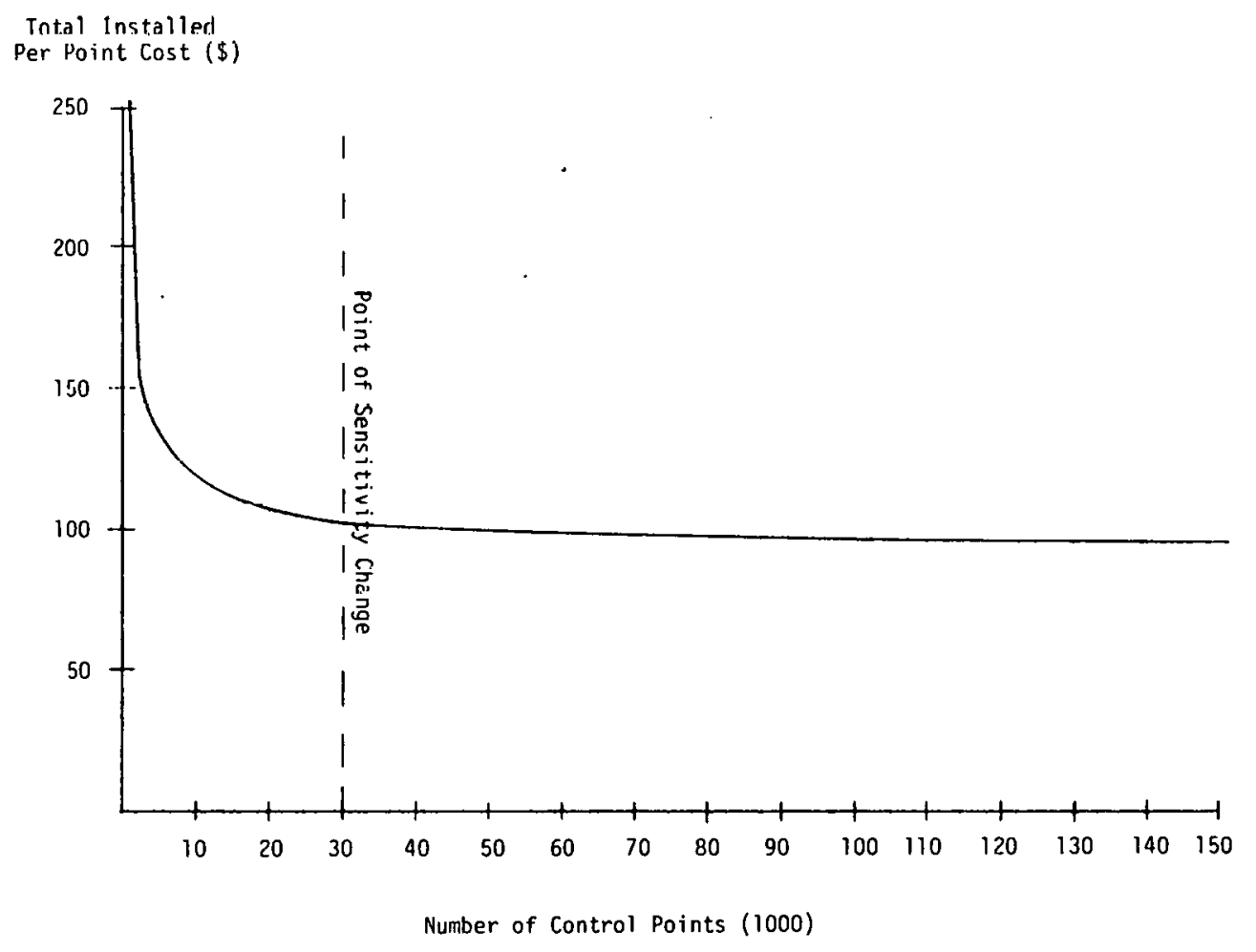

Table 2-3. Total Per Point Installed Cost of a Radio Control System as a Function of Receiver Saturation 
In order to determine the ranges of per point installed costs actually experienced by utilities equipped with radio systems, a series of interviews with utility personnel were conducted, and several utility project reports were examined.

Buckeye Power's statewide system utilizes 30 transmitters to control 45,000 switches. The cost of the Buckeye radio control system may be broken down as follows: in 1974-75, Buckeye purchased 40,000 switches at $\$ 62.80$ each and later purchased an additional 4,000 switches at $\$ 65$ each. These switches were given to the participating co-ops along with $\$ 15$ per switch to, at least partially, cover installation charges.

Buckeye spent approximately $\$ 250,000$ for its central control computer system, $\$ 9,800$ for each 10 -tone master transmitting station, $\$ 20,000$ for each 20-tone master transmitting station, and $\$ 17,500$ for each 20-tone slave transmitting station. The total installed cost of the Buckeye Radio System is estimated to be $\$ 105$ per point.

Detroit Edison has the 1argest radio control system with over 200,000 control points (switches), and an originally estimated per point installed cost of $\$ 50$. The cost of this system can be misleading, considering that no new equipment has been purchased since 1968. At that time, a total of $\$ 10$ million was spent for the purchase and installation of 200,000 switches, the retrofitting of ten existing transmitting stations for radio control, and the installation of a computerized central control system. Of this $\$ 10$ million, approximately $\$ 9.8$ million went for the purchase and installation of 200,000 receiver switches, and the remaining $\$ 200,000$ represents the costs of the central control and transmitting facilities. Normalizing these costs to 1980 dollars (at 6\% per annum) yields a present-day total cost of $\$ 20.1$ million or a total normalized per point cost of $\$ 701$.

Arkansas Power and Light utilizes 25 transmitters and is presently controlling approximately 40,000 residential air conditioners. Arkansas Power and Light estimates the total per point installed cost for this system to be $\$ 100$. This cost includes an average switch cost of $\$ 63$ and an average switch instaliation cost of $\$ 15$. 
The Greenville Utilities Commission presently controls approximately 4,400 air conditioners and 4,600 water heaters with a radio system. The total investment for this system is approximately $\$ 913,000$, an average per point installed cost of $\$ 101$. This figure includes a $\$ 14$ to $\$ 21$ per point installation cost.

The Cobb Electric Membership Corporation's radio project involves 14,000 switches controlled by three transmitters. The costs of the central control, transmitting equipment, telemetry, and peripheral equipment amounted to a total of $\$ 97,500$ installed. The switches cost $\$ 70$ each with an average installation cost of $\$ 15$ per switch. The total per point installed cost of this system is estimated to be $\$ 92$.

The average per point installed cost for the five utilities examined is $\$ 100$; this is reasonably representative of the costs incurred by most utilities with radio systems presently in place.

There are several factors that will affect the costs of new systems. The costs of computer-based control systems have dropped, and will probably continue to decline in the years to come. The apportioned per-point cost reduction that would result from these cost reductions will most likely be offset by expected concurrent increases in labor rates, due to inflation, for switch installation. A more important consideration in the future cost of radio systems is that the industry is moving away from the simple single-or double-tone addressing receivers to the more sensitive, more expensive digitally addressed receivers. This change is largeiy due to the need to overcome the problems of ever increasing congestion of the airways.

It is likely, then, that since these receivers average $\$ 15$ to $\$ 20$ more than the tonal type receivers, near-term costs for radio control systems will average in the $\$ 115$ to $\$ 125$ per point range.

Based on the previously derived load reductions of $1 \mathrm{~kW}$ for water heaters and $1.2 \mathrm{~kW}$ for air conditioners, a radio system costing $\$ 100$ per point would yield an average $\$ 91$ cost per controlled $\mathrm{kW}$. A $\$ 120$ per point cost would yield an average $\$ 109$ cost per controlled $\mathrm{kW}$. 
Radio C\&LC Equipment Manufacturers

Altran Electronics, Inc.

1400 W. 240th Street

Harbor City, California 90710

Fisher Pierce

Division of Sigma Instruments, Inc.

170 Pearl Street

Braintree, Massachusetts 02184

General Electric Company

Mobile Communications Division

Lynchburg, Virginia 24502

Motorola Communications and Electronics, Inc.

1303 East Algonquin Road

Schamburg, Illinois 60196

Plectron Corporation

Overton, Nebraska 68863

Regency Electronics, Inc.

7707 Records Street

Indianapolis, Indiana 46226

Sangamo

Energy Management Division

P.0. Box 48400

Atlanta, Georgia 30362

Scientific Atlanta

3845 Pleasantdale Road

Atlanta, Georgia 30340 
$2 \cdot 26$

THIS PAGE

\section{WAS INTENTIONALLY LEFT BLANK}




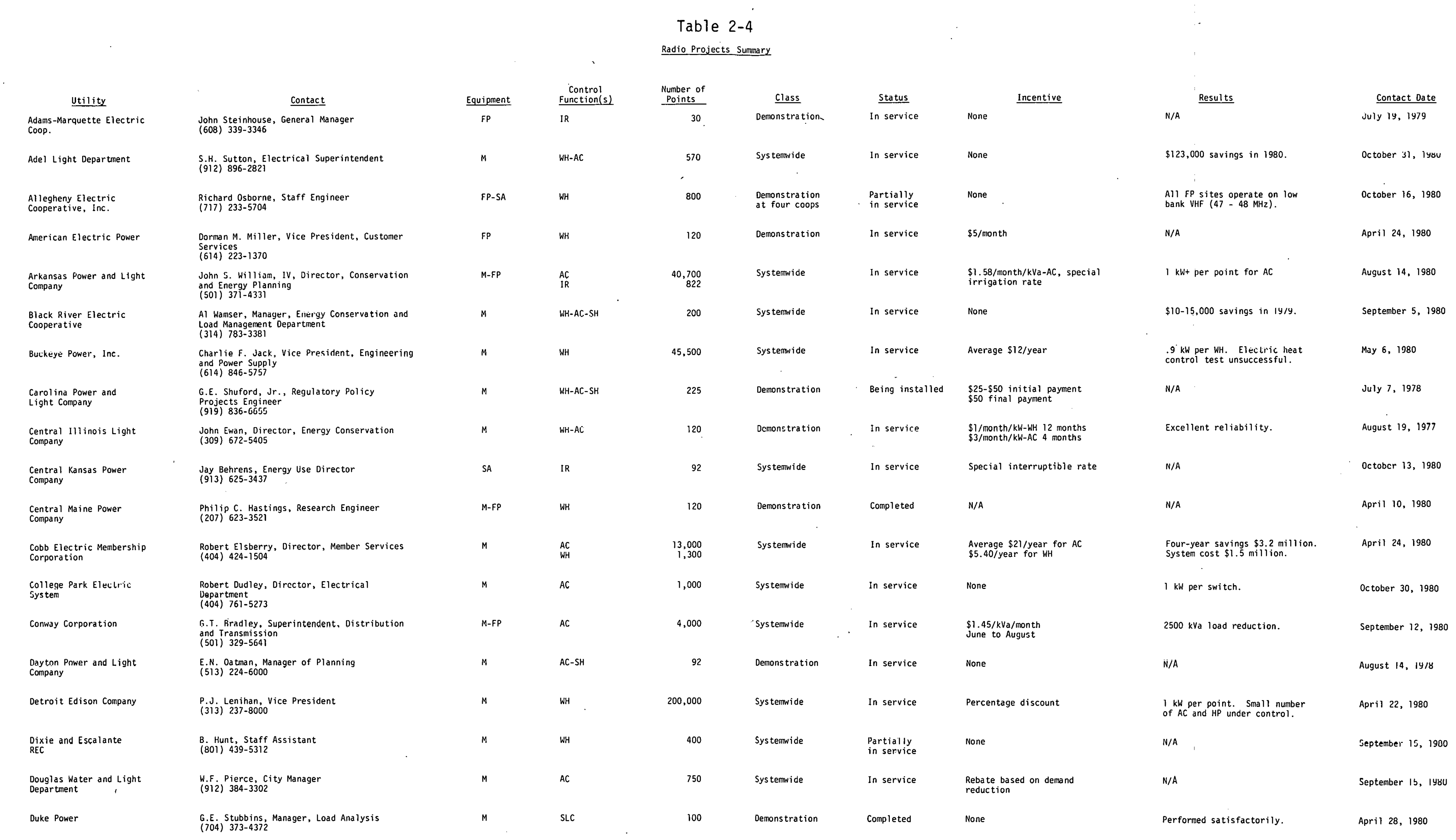


THIS PAGE

WAS INTENTIONALLY

LEFT BLANK 
Table 2-4 (Continued)

\begin{tabular}{|c|c|c|c|c|c|c|c|c|c|}
\hline$\underline{\underline{u t i l i t i t y}}$ & $\underline{\text { Contact }}$ & $\underline{\underline{E q u i p m e n t}}$ & $\begin{array}{c}\text { Control } \\
\text { Eunction(s) } \\
\text { fon }\end{array}$ & $\begin{array}{l}\text { Number of } \\
\text { points }\end{array}$ & Class & $\underline{\underline{s t a t u s}}$ & Incentive & $\frac{\text { Results/Remarks }}{\vdots}$ & Contact date \\
\hline $\begin{array}{l}\text { East Point Municipal } \\
\text { Electric Department }\end{array}$ & $\begin{array}{l}\text { Travis James, Electrical Coordinator } \\
(404) 765-1000\end{array}$ & M & AC & 2,750 & Systernwide & In service & None & $\$ 200,000$ annual savings. & October 30,1980 \\
\hline $\begin{array}{l}\text { Farmers Electric } \\
\text { Cooperative }\end{array}$ & $\begin{array}{l}\text { Gene Sweat Manager } \\
\text { (501) } 523-3691\end{array}$ & M & $\begin{array}{l}A C \\
I R\end{array}$ & $\begin{array}{l}256 \\
418\end{array}$ & Systenwide & In service & $\begin{array}{l}\$ 1.42 / / \mathrm{V} / \text { /month-AC } \\
\$ 5.79 / \mathrm{HP} / \mathrm{year}-\mathrm{IR}\end{array}$ & $\begin{array}{l}\$ 96,000 \text { gross savings } \\
\text { first year. }\end{array}$ & October 31, 1980 \\
\hline $\begin{array}{l}\text { Fittggerald Water, Light } \\
\text { and Bond Commission }\end{array}$ & $\begin{array}{l}\text { Robert fauuk, customer Relations } \\
(912) \text { 423-2016 }\end{array}$ & M & $\mathrm{AC}-\mathrm{WH}$ & 1,000 & Systemwide & In service & None & 1.6 $\mathrm{MW}$ projected reduction. & July 17,1979 \\
\hline $\begin{array}{l}\text { Florida Power } \\
\text { Corporation }\end{array}$ & $\begin{array}{l}\text { Wal lace L. Barron, Jr, Manager, Load } \\
\text { forrecasting and Research } \\
\text { (813) } 866-5440\end{array}$ & M & WH-AC & 170 & Demonstration & In service & $\begin{array}{l}\$ 2 / m \text { month } \text { wh, } \$ 3 / \text { month AC, } \\
\$ .68 / \text { kW/month commercial }\end{array}$ & $\begin{array}{c}\text { Report avai lable. } \\
\vdots\end{array}$ & September 9, 1980 \\
\hline Georgia Power Company & $\begin{array}{l}\text { Don G. Sabin, Manager, Energy Research } \\
(4044) 522-6000\end{array}$ & SA & AC & 6,700 & Demonstration & In service & None & Data being analyzed. & July 26,1980 \\
\hline 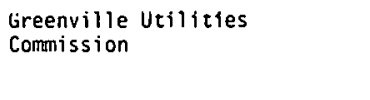 & $\begin{array}{l}\text { Charlese 0'H. Hurne, Jr., Director of } \\
\text { utilitities } \\
\text { (919) } 752-7166\end{array}$ & MrFP & WH-AC & 7,500 & Systemwidc & In scrvice & $\begin{array}{l}\$ 3.75 / \text { month for each } \\
\text { aappiance controlled } \\
4 \text { monthis col }\end{array}$ & 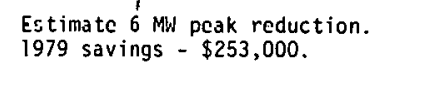 & April 18, 1980 \\
\hline $\begin{array}{l}\text { Griffin in Electric } \\
\text { Department }\end{array}$ & $\begin{array}{l}\text { J. Jones, Electric Engineer } \\
\text { (404) 227-2213 }\end{array}$ & ${ }_{R P}^{P P}$ & $\mathrm{AC}$ & 1,800 & Systenwide & In service & Maintenance call & 5-6 MW peak reduction. & September 24,1980 \\
\hline Gulf States Utilities & $\begin{array}{l}\text { Richard J. Peterrnan, Manager, Consumer } \\
\text { Servicices } \\
\text { (113) 838-6631 }\end{array}$ & M & AC & 190 & Demonstration & in service & $\$ 75$ total for 4 -month test & $\begin{array}{l}\text { Results inconclus ive, repeat ing } \\
\text { test in } 1980 .\end{array}$ & June 1,1980 \\
\hline $\begin{array}{l}\text { Highl ine Electric } \\
\text { Association }\end{array}$ & $\begin{array}{l}\text { Dick Stratton, System Engineer } \\
\text { (303) 854-2236 }\end{array}$ & FP & IR & 900 & Systemvide & In service & $\begin{array}{l}78 \text { discount weekly plan, } \\
14 \% \text { discount daily plan. }\end{array}$ & $\begin{array}{l}11 \mathrm{MW} \text { load reduction. } \$ 403,000 \\
\text { savings. }\end{array}$ & Apri1 21, 1980 \\
\hline $\begin{array}{l}\text { Kansas City Power and } \\
\text { Light }\end{array}$ & $\begin{array}{l}\text { Elizazbeth Sigle, Energy Managenent tngineer } \\
\text { (816) } 556-2153\end{array}$ & M-SA & AC & 80 & Demonstration & In service & AC tune up and warranty & $\mathrm{N} / \mathrm{A}$ & September 11, 1980 \\
\hline $\begin{array}{l}\text { Kansas Gas and Electric } \\
\text { Company }\end{array}$ & $\begin{array}{l}\text { Jeffrey w. Wright, Technical Services } \\
(316) \text { 261-6494 }\end{array}$ & M-FP & $A C$ & 140 & Demonstration & In service & $\begin{array}{l}\$ 2.50 / \text { VVa/month plus free } \\
\text { maintenance }\end{array}$ & 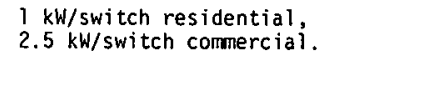 & May 8, 1980 \\
\hline $\begin{array}{l}\text { Lake land Department Electric } \\
\text { and Water Utiti ities }\end{array}$ & $\begin{array}{l}\text { R.G. Siegel, Super intendent, System Control } \\
\text { and delay } \\
(813) 682-1121\end{array}$ & M & AC-SH & 10 & Demonstration & - $\begin{array}{c}\text { Final } \\
\text { instal lation }\end{array}$ & None & $\mathrm{N} / \mathrm{A}$ & June 4,1979 \\
\hline $\begin{array}{l}\text { Laurenceville Electric } \\
\text { Departnent }\end{array}$ & $\begin{array}{l}\text { Don Martinn Manager } \\
(404) \text { 963-2414 }\end{array}$ & M & $\mathrm{AC}$ & 1,000 & Systemwide & $\begin{array}{l}\text { Partially } \\
\text { in service }\end{array}$ & $\begin{array}{l}\text { Non-participants are charged } \\
\text { S10/month extra }\end{array}$ & $\begin{array}{l}1.25 \mathrm{~kW} / \mathrm{switch} \text {. Savings of } \\
\$ 71,000 / \text { year. }\end{array}$ & September 15,1980 \\
\hline $\begin{array}{l}\text { Lumbee River Electric } \\
\text { Cooperative }\end{array}$ & $\begin{array}{l}\text { Der1 J. Hinson, Manager } \\
(919) \text { 843-4131 }\end{array}$ & M & $\begin{array}{ll}\text { WH } \\
A C .\end{array}$ & $\begin{array}{l}6,000 \\
2,000\end{array}$ & Systemwide & In service & $\$ 1.25 /$ month/appliance & $\$ 1,500,000$ gross savings to date. & April 25, 1980 \\
\hline $\begin{array}{l}\text { Mississippi Power and } \\
\text { Light Company }\end{array}$ & $\begin{array}{l}\text { John Ervinin Manager, Program Research and } \\
\text { oeveveloponent } \\
(601)(699-2311\end{array}$ & M-FP-SA & AC & 7,000 & $\begin{array}{l}\text { Partial } \\
\text { systemwide }\end{array}$ & In service & $\begin{array}{l}\$ 1 / k \text { Vaamonth } \\
\text { June - September }\end{array}$ & $\begin{array}{l}\text { Expect to expand to a potential } \\
35,000 \text { points. }\end{array}$ & August 28,1980 \\
\hline $\begin{array}{l}\text { Missouri Power and } \\
\text { Light Company }\end{array}$ & 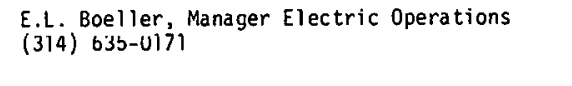 & M & $A C$ & 298 & Demonstration & İn service & $\$ 6 /$ month -4 months & $\mathrm{N} / \mathrm{A}$ & April 19, 1980 \\
\hline Nebraska Public Power & $\begin{array}{l}\text { Byrle E. Gross, Energy Managenent Manager } \\
\text { (4002) } 564-8561\end{array}$ & P & Ac-WH-SH & 35 & Demonstration & In service & $\$ 20$ one-time payment & Good equipment reliability. & May 1, 1980 \\
\hline Nevada Power Company & $\begin{array}{l}\text { Melvinc c. Sutton, Special Projects Engineer } \\
\text { (702) 385-5682 }\end{array}$ & R & $A C$ & 200 & Demonstration & In service & $\$ 1.51 / \mathrm{kW}-4$ Ironthls & $1.38 \mathrm{kw} /$ wuint luad reduct iun. & April 28, 1980 \\
\hline $\begin{array}{l}\text { North Arkansas Electric } \\
\text { Cooperative }\end{array}$ & $\begin{array}{l}\text { Larry R. Jackson, Load Management Supervisor } \\
\text { (501) } \\
8955-3221\end{array}$ & M-SA & $\mathrm{AC}-\mathrm{HH}$ & 3,000 & Systemwide & $\begin{array}{l}\text { Partiallyy } \\
\text { in service }\end{array}$ & None & $\begin{array}{l}\text { 2.2. MN load reduction. Net } \\
\text { savings }-\$ 35,000 .\end{array}$ & September 12, 1980 \\
\hline
\end{tabular}


THIS PAGE

WAS INTENTIONALLY

LEFT BLANK 
Table 2-4 (Continued)

\begin{tabular}{|c|c|c|c|c|c|c|c|c|c|}
\hline$\underline{\text { utilitity }}$ & Contact & Equipment & $\begin{array}{l}\text { Control. } \\
\text { Eunction(s) }\end{array}$ & 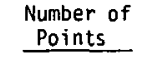 & class & Status & Incentive & Result ts/Remarks & Contact Date \\
\hline $\begin{array}{l}\text { North Attleboro Municipal } \\
\text { Electric Light Department }\end{array}$ & $\begin{array}{l}\text { John Miller, Manager, Energy Systems } \\
\text { (6677) } 699-7541\end{array}$ & " & WH & 800 & Systermwide & In service & $\begin{array}{l}\$ 5 / \text { month - manda tory for } \\
\text { WH cus tomers }\end{array}$ & N/A & October 31, 1980 \\
\hline $\begin{array}{l}\text { North Little Rock } \\
\text { Electric Departrent }\end{array}$ & $\begin{array}{l}\text { Buford Barentine, Director of Consumer } \\
\text { and Emmloyee Affairs } \\
\text { (501) } 372-0100\end{array}$ & M & AC & 2,000 & Systermwide & In service & $\$ 1.44 / \mathrm{kV} /$ /sumner months & N/A & July 20, 1979 \\
\hline $\begin{array}{l}\text { Oconto Electric } \\
\text { Cooperative }\end{array}$ & 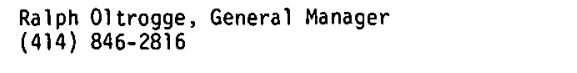 & M & WH & 1,400 & Sys termwide & In service & None & $\begin{array}{l}1.6 \mathrm{~kW} \text { per point load } \\
\text { reduction. }\end{array}$ & October 31,1980 \\
\hline $\begin{array}{l}\text { Oklanoma Gas and } \\
\text { Electric company }\end{array}$ & $\begin{array}{l}\text { A1 Strecker, Manager, Consumer Services } \\
\text { (405) } 272-3000\end{array}$ & R & ${ }_{A C}$ & 1,000 & $\begin{array}{l}\text { Partial } \\
\text { systenwide }\end{array}$ & Planning & $\begin{array}{l}\$ 2.17 / k v_{a} \\
\text { Juily - September }\end{array}$ & N/A & September 17,1980 \\
\hline $\begin{array}{l}\text { Otter Tail Power } \\
\text { Company }\end{array}$ & $\begin{array}{l}\text { Noble Hat ling, Supervisor, Cormercial Energy } \\
\text { Managament } \\
(218) 736-5411\end{array}$ & R & WH-SH & 5,000 & Systermwide & $\begin{array}{l}\text { Partially } \\
\text { in service }\end{array}$ & Controlled service rate & W/A & May 2, 1980 \\
\hline $\begin{array}{l}\text { Pacific Gas and Electric } \\
\text { Company }\end{array}$ & $\begin{array}{l}\text { R.M. Mertz, Manager, Energy Conservation and } \\
\text { Serviccs } \\
(415) \text { 781-4211 }\end{array}$ & SA-FP & $A C-\mathrm{WH}$ & 60,000 & Demonstration & $\begin{array}{l}\text { Partially } \\
\text { in service }\end{array}$ & $\begin{array}{l}\$ 8, \$ 6, \$ 4, \text { or } \$ 2 \text { per month - } \\
\text { May through September }\end{array}$ & $\begin{array}{l}1977 \text { and } 1978 \text { repurls are } \\
\text { available. }\end{array}$ & September 12,1980 \\
\hline $\begin{array}{l}\text { Petit Jean Electric } \\
\text { Cooperative }\end{array}$ & $\begin{array}{l}\text { Brad Mohr, Load Management Coordinator } \\
\text { (501) } 745-2493\end{array}$ & SA & AC-WH & 1,300 & Systermide & $\begin{array}{l}\text { Partially } \\
\text { in service }\end{array}$ & $\begin{array}{l}\$ 3.30 / \text { kVa/month }-A C-3 \text { months; } \\
\$ 99 / \text { month } \\
\text { WH - } 3 \text { months }\end{array}$ & $\begin{array}{l}\text { Project } 4,000 \text { points by summer } \\
1981 .\end{array}$ & October 14, 1980 \\
\hline $\begin{array}{l}\text { Potomac Electric Power } \\
\text { Company }\end{array}$ & $\begin{array}{l}\text { A. Earl Keicher, Consumer Services } \\
\text { (202) } 872-3080\end{array}$ & M & $\mathrm{AC}-\mathrm{HH}$ & 44 & Demonstration & In service & $\begin{array}{l}\$ 15 / \text { munth uver } 5 \text { muviths (AC \& wll); } \\
\$ 5 / \text { month over } 5 \text { months (AC) }\end{array}$ & N/A & May 2, 1980 \\
\hline $\begin{array}{l}\text { Prince will iam Electric } \\
\text { Cooperative }\end{array}$ & 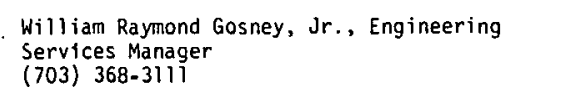 & SA-FP & $\mathrm{AC}-\mathrm{WH}$ & 5,000 & Sys tenwide & In service & None & $\begin{array}{l}\text { Expect to control 15,000 points } \\
\text { by } 1982 .\end{array}$ & April 25, 1980 \\
\hline $\begin{array}{l}\text { Rappahannock Electric } \\
\text { Cooperative }\end{array}$ & $\begin{array}{l}\text { Richard T- Young, Superintendent, Engineering } \\
\text { (204) 633-5011 }\end{array}$ & M & WH & 700 & Demonstration & $\begin{array}{l}\text { Partially } \\
\text { in service }\end{array}$ & None & $N / A$ & August 29, 1980 \\
\hline $\begin{array}{l}\text { Riceland Electric } \\
\text { Cooperative }\end{array}$ & $\begin{array}{l}\text { H. Buerkle, Manager, Operations } \\
\text { (501) } 673-2695\end{array}$ & M & $\underset{A C}{I R}$ & $\begin{array}{r}300 \\
30\end{array}$ & Systenmide & $\begin{array}{l}\text { Partially } \\
\text { in scrvice }\end{array}$ & $\begin{array}{l}\text { Irrigation }-\$ 6.40 / \text { month/HP, } \\
\text { 3-month minimum }\end{array}$ & $2,000 \mathrm{~kW}$ load reduction. & September 23, 1980 \\
\hline Rural Electric Company & $\begin{array}{l}\text { Lloyd Sisson, Assistant Engineer } \\
\text { (307) 245-3267 }\end{array}$ & FP & IR & 400 & Systenwide & On order & Not yet determined & N/A & October 29, 1980 \\
\hline $\begin{array}{l}\text { Sacranento Municipal } \\
\text { Utiti ity Districtict }\end{array}$ & $\begin{array}{l}\text { Daryl Mayfield, Project Coordinator } \\
(916) \text { 452-3211 }\end{array}$ & m & $A C$ & 6,250 & Systenwide & In service & $\$ 2 /$ month -4 months & N/A & May 1, 1980 \\
\hline $\begin{array}{l}\text { San olego Gas and } \\
\text { Electric Company }\end{array}$ & $\begin{array}{l}\text { John A. Roy, Project Manager, Load Management } \\
\text { (404) } 522-6060\end{array}$ & SA & ${ }_{W H}^{A C}$ & $\begin{array}{r}7,200 \\
425\end{array}$ & Demonstration & Planning & 3 levels - $\$ 0, \$ 25$, and $\$ 50 / y r$ & $\begin{array}{l}\text { Eneray comirss ton-mandated } \\
\text { program. }\end{array}$ & July 9, 1980 \\
\hline $\begin{array}{l}\text { San Diego Gas and } \\
\text { Flertrir fnmpany }\end{array}$ & $\begin{array}{l}\text { Thomas D. Stickels, Project Manager, Load } \\
\text { Managenent } \\
(714) \text { 232-4iż2 }\end{array}$ & SA & $\begin{array}{l}\text { AC } \\
\text { (commercial) }\end{array}$ & 250 & Demonstration & Planning & $\$ 1.50 / \mathrm{kW} \mathrm{cummect}$ luad/month & N/A & July 9, 1980 \\
\hline 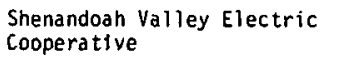 & $\begin{array}{l}\text { c.0. . . ine, System Engineer } \\
(703) \text { (879-2551 }\end{array}$ & FP & WH & 2,500 & Demuns Lratiun & $\begin{array}{l}\text { Partially } \\
\text { in service }\end{array}$ & None & Exper.t $8-10 \%$ peak reduction. & April 21, 1980 \\
\hline $\begin{array}{l}\text { Southern Cali ifornia } \\
\text { Edison Company }\end{array}$ & $\begin{array}{l}\text { E.A. Myers, vice President } \\
\text { (213) } 572-2001\end{array}$ & SA & $A C$ & 2,250 & Demonstration & In service & $\begin{array}{l}\$ 0, \$ 3, \text { or } \$ 6 / \text { ton/month for } \\
12 \text { months }\end{array}$ & Prel iminary report avai lable. & May 2, 1980 \\
\hline $\begin{array}{l}\text { Sulphrr Springs val ley } \\
\text { Electric cooperative }\end{array}$ & $\begin{array}{l}\text { Howard D D Bethel, General Manager } \\
(602)(384-2221\end{array}$ & FP-P & IR & N/A & Systemwide & In scrvice & $\begin{array}{l}\text { 8\% discount weekly plan; } \\
\text { 25\% discount daily plan }\end{array}$ & $\begin{array}{l}10,000 \text { horsepower now under } \\
\text { control. }\end{array}$ & April 29, 1980 \\
\hline $\begin{array}{l}\text { Sunter Electric } \\
\text { Membership Corporation }\end{array}$ & $\begin{array}{l}\text { D.L. Hart ley, Manager, Operations and } \\
\text { inginepring } \\
(912) 924-8041\end{array}$ & M & $\begin{array}{ll}\mathrm{WH} \\
\mathrm{AC}\end{array}$ & $\begin{array}{l}2,300 \\
1,200\end{array}$ & Systemwide & In service & None & $\begin{array}{l}\text { Estimate } 1 \mathrm{~kW} / \mathrm{AC}, .7 \mathrm{~kW} / \mathrm{NH} \\
\text { load reduction. }\end{array}$ & September 15, 1980 \\
\hline
\end{tabular}


THIS PAGE

WAS INTENTIONALLY

LEFT BLANK 
Table 2-4 (Continued)

\begin{tabular}{|c|c|c|c|c|c|c|c|c|c|}
\hline Utility & Eontact & Equiument & $\begin{array}{l}\text { Control } \\
\text { Functions: }\end{array}$ & $\begin{array}{l}\text { Suriserer of } \\
\text { points } \\
\end{array}$ & class & Scatus & Incentive. & Pesuluts & Contact Date \\
\hline Tennessee Valley Authority & $\begin{array}{l}\text { Patricia Marris, Load Managenent Branch } \\
\text { (615) 755-3591 }\end{array}$ & м & WH-AC-SH & 457 & Denonstration & In service & $\begin{array}{l}\$ 50 \text { total for } W H, \$ 900 \text { total } \\
\text { for WHACAC-SH, } \$ 130 \text { for } W H-H P\end{array}$ & Data resuction in progress. & April 28, 1980 \\
\hline Tennessee Val ley Auttiori ity & $\begin{array}{l}\text { Harold G. Momble, Supervisor, Residential } \\
\text { anit } \\
\text { (615) } 755-6773\end{array}$ & Undetermined & Ac-WH & 50,000 & Denonstration & Underway & $\$ 5 /$ month — June through September & $\begin{array}{l}\text { Ten power distributors are } \\
\text { involved. }\end{array}$ & July 25,1980 \\
\hline $\begin{array}{l}\text { Thomasville kater and } \\
\text { Light vepartment }\end{array}$ & 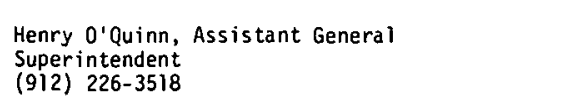 & м & AC & 1,720 & Systemwide & In service & $\$ 7.50 /$ month - 4 months & $2400 \mathrm{~kW} \cdot 10 \mathrm{ad}$ reduction. & Septenber 23, 198 \\
\hline Thunb Electric Cooperative & $\begin{array}{l}\text { B. Rumptz, Manager, Consumer Services } \\
\text { (517) } 558-8571\end{array}$ & FP & WH & 1,600 & Denonstration & In service & $\$ 1.50 /$ month & $\begin{array}{l}\text { Ult tima tely systemwide. } \\
\text { May become mancia tory. }\end{array}$ & September 18,1980 \\
\hline Utah Power and Light & $\begin{array}{l}\text { Brian Holt, oirector, custoner Service, } \\
\text { Planning, and Research } \\
\text { (801) } 533-4177 \text {. }\end{array}$ & M-Fp & 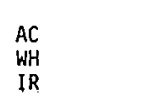 & $\begin{array}{r}335 \\
192 \\
1,800\end{array}$ & $\begin{array}{l}\text { AC-HH Demunis Lration } \\
\text { IR Systenvide }\end{array}$ & In service & Nong & N/A & August 13, 1980 \\
\hline $\begin{array}{l}\text { Virginia Electric and } \\
\text { Power Company }\end{array}$ & 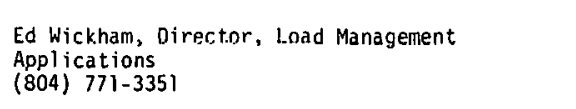 & FP & uH & 1,000 & Demonstration & In service & $\$ 1.85 /$ month & $\begin{array}{l}\text { Technical eval luation completed. } \\
\text { Costs benefit analysis in } 6 \text { to } \\
8 \text { months. }\end{array}$ & July 14, 1980 \\
\hline $\begin{array}{l}\text { Wabash Valley Power } \\
\text { Association }\end{array}$ & $\begin{array}{l}\text { Ron Hale, Manager, Systems Operations } \\
\text { (317) 247-1596 }\end{array}$ & M & WH & 20,000 & Systemmide & on order & None & $\begin{array}{l}\text { Program will involve } 24 \\
\text { distribution cooperatives. }\end{array}$ & November 13,1980 \\
\hline $\begin{array}{l}\text { Walton Electric Membership } \\
\text { cooperative }\end{array}$ & $\begin{array}{l}\text { Howard Turner, Menber Services Representative } \\
\text { (404) } 267-2505\end{array}$ & m & Ac- -WH & 5,000 & Systemwide & In service & Mone & 1978 savings exceeded $\$ 578,000$ & May 30, 1979 \\
\hline $\begin{array}{l}\text { Waushara Electric } \\
\text { Cooperative }\end{array}$ & $\begin{array}{l}\text { Freed flarasha, General Manager } \\
\text { (414) } 787-3311\end{array}$ & Fp & 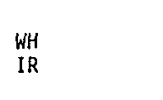 & $\begin{array}{l}150 \\
125\end{array}$ & Sys termivide & $\begin{array}{l}\text { Partially } \\
\text { in service }\end{array}$ & $\begin{array}{l}\$ 1.50 / \text { month }-12 \text { months } \\
\text { special control rate }\end{array}$ & Started in May 1980 & October 30,1980 \\
\hline $\begin{array}{l}\text { York county Rural } \\
\text { Public Power District }\end{array}$ & $\begin{array}{l}\text { Robert J. Couper, Director, Customer } \\
\text { Services } \\
(402) \text { 362-3355 }\end{array}$ & FP & IR & 202 & Systenwide & In service & $\$ 4$ to $\$ 9 / \mathrm{HP} / \mathrm{year}$ & $\begin{array}{l}\text { Can remove up to } 4000 \mathrm{HP} \\
\text { from system load. }\end{array}$ & May 8, 1980 \\
\hline $\begin{array}{l}\begin{array}{l}\gamma-\text { Wh Electric Association, } \\
\text { inc. }\end{array} \\
\text { a }\end{array}$ & $\begin{array}{l}\text { Terry Hal1, System Engineer } \\
\text { (303) } 345-2291\end{array}$ & FP & IR & 700 & Sys temride & In scrvice & 8 to $9 \%$ rate reduction & $\begin{array}{l}\text { Can remove up to } 5 \mathrm{MW} \text { from } \\
\text { system load. }\end{array}$ & October 31, 1980 \\
\hline Legend & & & & & & & & & \\
\hline 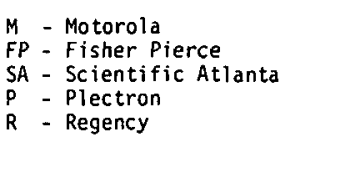 & 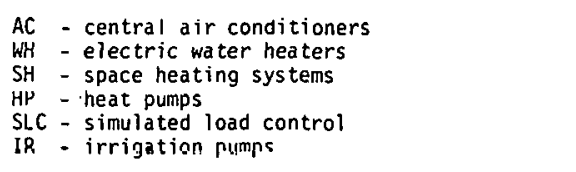 & & & & & & & & \\
\hline
\end{tabular}


THIS PAGE

WAS INTENTIONALLY

LEFT BLANK 
ARKANSAS POWER \& LIGHT COMPANY

REVISED 1980

P.0. Box 551

Little Rock, Arkansas 72203

(501) $371-4000$

John S. Williams, IV, Director, Conservation and Energy Planning

James P. Herden, Manager, Corporate Economics

SYSTEM: $\quad$ Radio

SUMMARY: Based on successfur tests in 1975 and 1976 with 310 customers, twenty-five transmitters have been installed to control residential and commercial air conditioners and irrigation pumps on the Arkansas Power and Light system. The radio switches are operated on a cycle basis using ten tones to switch off air conditioning units for two non-consecutive 7-1/2-minute periods each hour. Irrigation pumps are switched off for a maximum of 2-1/2 hours on peak days.

FUNCTION: $\quad$ To cycle off residential and commercial central air conditioners for 7-1/2 minutes twice each hour in peak periods. To control irrigation pumps for periods of up to $2-1 / 2$ hours.

EQUIPMENT: Twenty-five Motorola transmitters, Motorola and Fisher Pierce receiver switches; central control at dispatch center, Pine Bluff, Arkansas.

SAMPLE: Open to all air conditioning customers and all irrigation customers. Program presently involves 40,200 residential, 485 commercial, and 822 irrigation customers.

INCENTIVE: Residential and Commercial - \$1.58(residential) and $\$ .92$ (commercial) per kVA of connected compressor capacity controlled per month for three months. Irrigation. $\$ 11.64$ per horsepower controlled per season. 
INTERVIEW

DATE:

August 14, 1980.

RESULTS: $\quad$ System has shown a high level of reliability with good customer response. If all 136,000 air conditioning customers subscribe to the program, a 130-megawatt savings during peak demand is possible. Projected load reductions obtainable through irrigation control exceed $70 \mathrm{MW}$. 
BUCKEYE POWER, INC.

REVISED 1980

6677 Busch Boulevard

Columbus, Ohio 43229

(614) $846-5757$

Charlie F. Jack, Vice President, Engineering and Power Supply

Herbert E. Caldwe11, Jr., Supervisor, Load Management

SYSTEM: $\quad$ Radio

SUMMARY: This radio control system, utilizing the Motorola 800-W radio switch, is presently saving Buckeye Power and its member cooperatives an estimated $\$ 2,500,000$ annually, through the control of electric water heaters during onpeak load periods. The program is available to all of Buckeye Power's member cooperatives on a voluntary basis; 26 of the 28 member coops are presently participating in the program. Each participant experiences a savings in the purchase cost of its wholesale power, by virtue of reduced billing demand due to the operation of the load management system during peak load periods. The 1980-81 winter period will be the seventh year of operation for this system. It is expected that, by the end of this period, the total net savings achieved by the program will amount to more than double the total capital investment required for equipment to date.

FUNCTION: $\quad$ The water heaters are controlled during Buckeye Power's peak load periods which normally occur during the coldest winter days. During times of peak load, the water heaters are controlled for periods ranging from two to as long as five hours. The average off-time during a deferral is normally between three and three and one-half hours. Total average control time during a typical winter operating season ranges from 20 to 40 hours depending, to a large extent, upon the severity of the weather. 
EQUIPMENT: The Motorola system utilizes thirty 300-Watt radio transmitters, at various locations throughout the state of Ohio, to control radio switches installed on consumers' water heaters. Leased telephone lines connect the computer control center at Buckeye Power's headquarters with the load telemetry points and the master base stations. Slave base stations receive their control commands through radio frequency communications from the master stations located in the same geographic area.

SAMPLE:

Available to all cooperative consumers with electric water heaters in 26 of the 28 cooperatives in Ohio served by Buckeye Puwer, Iirc.

INCENTIVE: The incentive given to participating consumers by various cooperatives ranges from no direct monetary incentive to as much as $\$ 24.00$ per year. In cases where an incentive is used, it is normally through the cooperative's retail rate, which provides a credit to those consumers having a radio switch. Approximately $40 \%$ of the participating cooperatives are using a direct monetary incentive which, on an average, amounts to about $\$ 12.00$ per year. Cooperatives not using incentives are giving consideration to implementing them.

INTERVIEW

DATE:

May 1, 1980.

STATUS: In service.

RESULTS: $\quad$ Presently, there are approximately 45,500 radio switches installed on consumers' water heaters, located on the systems of the 26 participating cooperatives. Demand reduction during peak load periods, occurring between 6 p.m. and 7 p.m., average $0.9 \mathrm{~kW}$ per 
connected water heater switch. Based on the demand reduction of $0.9 \mathrm{~kW}$ per switch and Buckeye Power's percent wholesale rate to its member cooperatives, the annual savings to participating cooperatives is in the range of $\$ 35.00$ to $\$ 50.00$ per year per connected switch, depending upon the individual cooperative's monthly demands.

REMARKS: $\quad$ Buckeye Power, Inc., through two of its member cooperatives (Licking Rural Electrification, Inc., and Pioneer Rural Electric Cooperative, Inc.), has implemented an electric heat control demonstration program during the 1978-79 and 1979-80 winter periods. This program involves the installation of a total of 80 radio switches on heat pumps, electric furnaces and baseboard/ceiling cable types of central heating systems. The electric heating systems are controlled on a cyclic basis during periods of peak demand in an effort to determine the optimum control parameters, which would include considerations for consumer comfort as well as maximum demand reductions.

Conclusions drawn from the test results indicate that cyclic control of non-storage types of electric heat is not viable at this time. Buckeye Power has, therefore, decided to abandon this test program and has plans to explore other means of managing electric heating load to achieve practicable demand reductions. 
COBB ELECTRIC MEMBERSHIP CORPORATION

REV ISED 1980

Box 369

Marietta, Georgia 30061

(404) 424-1504

Robert Elsberry, Director, Member Services

Vickie Crowley, Member Service Representative

SYSTEM: $\quad$ Radio

SUMMARY: $\quad$ This program of air conditioner cycling via radio switch is now entering its fifth year of operation. In summer 1976, Cobb Electric Membership Corporation had 5,000 residenlidal rir coundiliuners under cycling control; 3,300 more were added in 1977 and 3,000 more were added in the summer of 1978. 750 electric water heater controls were also added in 1978. Going into the peak season of 1980, 'Cobb Electric Membership Corporation has over 13,000 air conditioners and in excess of 1,300 water heaters under control.

FUNCTION: To cycle residential air conditioners and electric water heaters. The air conditioners are divided into ten groups, each group heing rontrnlled by a separate tone command. When load control is needed, group one is cycled oft for a 7-minute interval. Each subsequent group is cycled off for a similar period, beginning 2.7 minutes after the start of the preceeding group cycling. Cycling continues as required. In this manner, Cobb Electric Membership Corporation can control peak loads while avoiding any large sudden fluctuations in system loads. Water heaters are cycled off and on as necessary to achieve load control.

EQUIPMENT: Motorola receiver switches with three transmitters (one air conditioner transmitter, one back-up air conditioner transmitter, and one water heater transmitter). Substation monitoring console giving demand information from all 
fourteen substations.

SAMPLE: $\quad$ Open to all residential customers. Total air conditioner controls to date exceed 13,000 and over 1,300 electric water heaters have been added since January, 1978.

INCENTIVE: Customers participating in the program receive a rebate at the end of the four month summer season based on $\$ 4.00$ per $\mathrm{kW}$ of controlled air conditioner load and $\$ 1.20 \mathrm{per}$ $\mathrm{kW}$ of controlled water heater load. Average credit per year is $\$ 21.00$ for a controlled air conditioner and $\$ 5.40$ for a water heater. 1978 was the first year credit was offered. In excess of 8,300 volunteers agreed without a direct monetary incentive.

MONITORING: The $\mathrm{kW}$ demands of the fourteen substations are monitored and relayed via phone line telemetry every 30 seconds. Load control decisions can then be made, either manually or automatically.

INTERVIEW

DATE:

April 24, 1980.

STATUS: In service.

RESULTS: $\quad$ Estimated savings exceeding $\$ 3.2$ million in purchased power demand charges have been realized thus far. Investment in control system totals slightly more than $\$ 1.5$ million to date.

REMARKS: $\quad$ Customer acceptance excellent. 
DETROIT EDISON COMPANY

2000 Second Avenue

REVISED 1980

Detroit, Michigan 48226

(313) $237-8000$

P. J. Lenihan, Assistant Vice President

SYSTEM: $\quad$ Radio

SUMMARY: This pioneering load management system now controls 200,000 electric water heaters across its 7,600-squaremile territory, permitting the system operator to obtain upwards of 200 meqawatts emergency load reduction or 90 megawatts of peak. load relief under a cycling program. Radio was selected because of flexibility, economy, and ease of installation.

At an experimental rate, the radio system has been used to cycle about 280 air conditioners for fifteen to twenty minutes per hour for no more than five hours per day. Minimal customer discomfort has been reported.

FUNCTION: $\quad$ To switch electric water heaters and air conditioners off and on using radio signals.

EQUIPMENT: $\quad$ Motorola -- 10 transmitters and over 200,000 receivers.

SAMPLE: Available to all water heater customers. 280 residential volunteers with central air conditioning.

INCENTIVE: Special controlled water heater rate provides $40 \%$ discount on middle step of current inverted domestic rate. Experimental air conditioning rate limited to 500 volunteers. This provides seven mills discount per $\mathrm{kWh}$ for 1,000 kWh after the first $800 \mathrm{kWh}$ per month.

MONITORING: No on-site instruments. 
INTERV IEW

DATE:

STATUS:

RESULTS:
Apri1 22, 1980

In service.

More than $95 \%$ reliability of radio system. Water heating cycling provides 90 megawatts of load relief and 200 megawatts of emergency load reduction.

The experimental program for air conditioning cycling, while eliciting no complaints, has resulted in small customer savings and negligible peak load reduction. Only 280 customers of a quota of 500 have volunteered for the rate. 
GEORGIA POWER COMPANY

NEW 1980

270 Peachtree Street

Atlanta, Georgia 30302

(404) 522-6060

Don G. Sabin, Manager, Energy Research

SYSTEM: $\quad$ Radio

SUMMARY: $\quad$ In a pilot program, Georgia Power is cycling 6,700 air conditioners in 6,000 residences during control periods of 3 to 7 hours. Three groups of 169 residences each are being monitored. One group has $0 \%$ cycling off...time, another has $25 \%$ off-time, and the third has $50 \%$ off-time. Also, to test rellabllily and lu Jelermine maximuin luad reduction,Georgia Power has twice conducted a total-off "scram" of all units at $100^{\circ} \mathrm{F}$. Data is being analyzed.

FUNCTION: $\quad$ To cycle air conditioners for varying periods and to disconnect all units in emergencies.

EQUIPMENT: $\quad$ Scientific Atlanta.

SAMPLE: $\quad 6,000$ residences $-6,700$ control points.

INCENTIVE: None.

MONITORING: $\quad$ Load survey meters in 507 residences.

INTERVIEW

DATE :

August 11, 1980

STATUS: $\quad$ In service - June 1980.

RESULTS: $\quad 1980$ interim report is now available. 
REMARKS: The previous project using the same Scientific Atlanta Equipment with receivers and PLC injectors on poles was abandoned because of low volunteer customer density on the respective secondaries. 
GREENVILLE UTILITIES COMMISSION

200 W. Fifth Street, P.0. Box 1847

REVISED 1980

Greenville, North Carolina 27834

(919) $752-7166$

Charles O'H. Horne, Jr., Director of Utilities

SYSTEM: $\quad$ Radio

SUMMARY: $\quad$ Faced with a $90 \%$ ratchet demand charge and growing annual peak demands, Greenville Utilities Commission committed itself in 1977 to a radio-system-based load management program. In the first year of operation (summer of 1978), a total of 5,000 points of control were instailed, which rcsulted in a 4-MW reduction in pcak demand. In the summer of 1979, Greenville Utilities Commission had approximately 4,000 water heaters and 3,500 aị conditioners under control, resulting in an estimated 6-MW reduction in peak load. 2,000 switches will be added in 1980 .

FUNCTION: $\quad$ Cycle central air conditioners 7-1/2 minutes each halfhour during control periods; turn off water heaters as required.

EQUIPMENT: Motorola transmitting system, 5,000 Motorola receiver switches, 2,500 Fisher Pierce receiver switches.

SAMPLE: $\quad$ Presently controlling 7,500 points (4,000 water heaters and 3,500 air conditioners). Open to all customers. Project eventual control of 8,000 to 10,000 points.

INCENTIVE: $\quad \$ 3.75$ per month over four summer months for each appliance controlled. Maximum of $\$ 30$ per year incentive.

MONITORING: Normal system monitoring. 
INTERV IEW

DATE:

Apri1 29, 1980.

STATUS: In service.

RESULTS: $\quad$ In 1978, 5,000 switches were installed, resulting in a 4-MW reduction in peak demand, and in 1979, implementation of 7,500 switches resulted in a 6-MW reduction. Total capital cost through 1979: $\$ 650,000$. Two-year operating savings: $\$ 395,000$.

REMARKS: $\quad$ Presently have waiting list for switch installations. December 1979 report available. 
HIGHLINE ELECTRIC ASSOCIATION

P.0. Box 57

REVISED 1980

Holyoke, Colorado 80734

(303) $854-2236$

Dick Stratton, System Engineer

SYSTEM: $\quad$ Radio Irrigation Control

SUMMARY: Approximately 900 pumps used for irrigation/sprinkling are under radio control by Highline Electric Association during July and August, in order to reduce the summer peak. Typ1c.al summer peak luad is $150.000 \mathrm{~kW}$, whily blie willler. load drops to around $20,000 \mathrm{~kW}$. The summer peak is mainily due to farm energy uso. A dual-1ncentive methor is userl, with a larger incentive offered when Highline Electric Association can cut the load' on any day without advance notice. Highline Electric Association plans to expand the program to include as much of the pumping load as possible; then, consideration will be given to controlling other types of loads.

FUNCITON: $\quad$ Reduce sumer peak demand by radio control of irrigation pumps. When substation load exceeds preset level, pumps arc shut off by remotc control. System used only during July and August to reduce ratchet on purrhased pnwer (10n\% ratchet for loads in excess of base year load).

EQUIPMENT: Fisher Pierce encoder and receivers.

SAMPLE: $\quad 900$ pumps individually controlled and billed (some farms have more than one pump).

INCENTIVE: Two separate plans are available: a weekly plan, offering a $7 \%$ discount, and a daily plan, offering a $14 \%$ discount. Under the weekly plan, the customer and Highline Electric Association agree on one specific day per week on which 
the customer's load will be controlled. Under the daily plan, the load can be controlled at any time without advance warning. Sixty percent of the participants are on the daily plan, and forty percent on the weekly plan. The incentive is applied to the annual rate.

MONITORING: $\quad \mathrm{kW}$ demand is monitored at each of sixteen substations.

INTERV IEW

DATE:

STATUS: $\quad$ Program is in third summer of operation and is an ongoing project. It began in 1978 with 230 pumps, mostly in the utility's Nebraska service area, and was expanded into Colorado in 1979 .

RESULTS: 1979 results: $11 \mathrm{MW}$ were controlled on peak, resulting in an estimated $\$ 403,000$ savings in power and ratchet costs. of this amount, $\$ 378,000$ was given to Highline Electric Association customers in the form of a discounted irrigation rate. Because of the success in 1979, and the close relationship of savings to discounts, the same incentives (7 \& 14\% discounts) will be offered for 1980 . 
KANSAS GAS AND ELECTRIC COMPANY

201 North Market Street

REVISED 1980

Wichita, Kansas 67201

(316) 261-6494

Jeffrey W. Wright, Technical Services

SYSTEM: $\quad$ Radio

SUMMARY: During the summer of 1978, 115 residential customers with central air conditioning participated in a program of air conditioner cycling. Because of the positive results of this test, a similar test with twenty-tive commercial businesses was done during the summer of 1979. The businesses, located on different primary eireuits, were divided into subgroups. Each subgroup in sequence had its air conditioners cycled off for 7-1/2 minutes each halfhour by a radio-controlled switch. The controlled circuits were monitored for total demand and kilowatthours. The program is complete and final reports are available.

FUNCTION: $\quad$ Cycle off commercial and residential air conditioning 7-1/2 minutes per half-hour during peak hours.

EQUIPMENT: Motorola transmitter with Fisher Pierce controller. Fisher Picrce and Motorola receiver switches.

SAMPLE: $\quad 115$ residential customers with central air and 25 commercial customers with 54 roof-top air conditioners on three test circuits.

INCENTIVE: $\quad \$ 2.50$ per month per kVA of air conditioning controlled, plus free maintenance of equipment during testing period.

MONITORING: $\quad$ Printing demand meters recording at 5 -minute intervals, G9 recording charts to measure kilowatt demands at 15-minute intervals and kilowatthour meters. Monitoring points are 
limited to primaries of the controlled circuits.

\section{INTERV IEW}

DATE:

May 8,1980

STATUS: $\quad$ Complete.

RESULTS: $\quad 1 \mathrm{~kW} / \mathrm{switch}$ for residential customers with good customer acceptance. Commercial test results averaged $2.5 \mathrm{~kW} / \mathrm{switch}$ with few customer complaints. 
LUMBEE RIVER ELECTRIC MEMBERSHIP CORPORATION

Box 830

Red Springs, North Carolina 28377

REVISED 1980

Berl J. Hinson, Manager

SYSTEM: $\quad$ Radio

SUMMARY: $\quad$ To reduce peak load growth in its four-county service area, Lumbee River Electric Membership Corporation offers to its 18,500 member consumers the option of a radio control switch on their electric water heaters and central air conditioners to be contrnllepd from a transmitter at the Red Springs headquarters. The cooperative's wholesale rates are ratcheted at $95 \%$ of summer peak demand. In 1977, 3,000 electric water heaters and 1,000 central air conditioners were controlled for a tive-megawatt reduction of the summer peak demand. During the summer of 1978, 5,000 electric water heaters and 1,500 central air conditioners were controlled for a reduction of more than seven megawatts of demand. In 1979, 6,000 electric water heaters and 2,000 central air conditioners were controlled for a nine-megawat.t. redurtion of the summer peak demand.

FUNCTION: $\quad$ By radio signal, to cycle water heaters off for up to four hours, air conditioners for seven minutes per half hour.

EQUIPMENT: $\quad$ Motorola transmitter and receivers.

SAMPLE: Available to all member consumers with these appliances.

INCENTIVE: $\quad$ Credit of $\$ 1.25$ per month per appliance switched.

MONITORING: Telemetering from four power delivery points to headquarters. No monitoring on consumer premises. 
INTERV IEW

DATE:

Apri1 25, 1980

STATUS: In service.

RESULTS: $\quad \$ 1,500,000$ gross savings and $21-\mathrm{MW}$ reduced load for a three-year period.

REMARKS: A consultant evaluated proposals from several manufacturers and, on a cost/benefit analysis, recommended Motorola radio. A spare transmitter and a standby power generator have been provided at the headquarters building. Prolonged water heater outages during extreme temperatures resulted in minimal complaints. Additional control devices have been installed to coincide with system growth.

In 1980, a wholesale rate increase will be implemented and the $95 \%$ ratchet discontinued. 
NEBRASKA PUBLIC POWER DISTRICT

P.0. Box 499

REVISED 1980

Columbus, Nebraska 68601

(402) $564-8561$

Byrle E. Gross, Energy Management Manager

Joe Pacovsky, Energy Management Engineer

SYSTEM: $\quad$ Radio

SUMMARY: Nebraska Public Power District is involved in a project designed to test the reliability of remote radio control systems, assess customer acceptance of load control, and determine basic peak. Inad reduction possibilities obtainable through a program of air conditioner and water heater control. Plectron Radio Equipment, Overton, Nebraska, is being used in this project.

FUNCTION: Cycle residential air conditioners off for $7-1 / 2$ minutes every half-hour; cycle residential water heaters as required. Control of electric space heating has been added.

EQUIPMENT: Plectron FM radio control system with automated scanning control system.

SAMPLE: $\quad 35$ homes in York, Nebraska. 20 homes have air conditioners under control; 15 homes have air conditioners and water heaters under control.

INCENTIVE: $\quad \$ 20$ one time payment for those participants completing test.

MONITORING: All test homes are being monitored via strip chart recorders on primary feeder. A similar group of homes is being monitored in a like fashion. Data from this control group will serve as a comparative base. 
INTERVIEW

DATE: $\quad$ May 1,1980

STATUS: $\quad$ In service.

RESULTS: $\quad$ Preliminary indications suggest good equipment reliability. Further testing this summer will include varying cycling times. Project has been extended to include control of electric space heating. 
PACIFIC GAS AND ELECTRIC COMPANY

REV ISED 1980

77 Beale Street

San Francisco, California 91406

(415) 781-4211

R.M. Mertz, Manager, Energy Conservation and Services

SYSTEM: $\quad$ Radio - Residential

SUMMARY: The initial program started in 1977 and continued through the 1979 air conditioning season, involving 1,500 customers. An expanded program will involve approximately 60,000 custumers and cunlinue through 1902. Central air conditioners and electric water heaters in high-, medium-, and low-

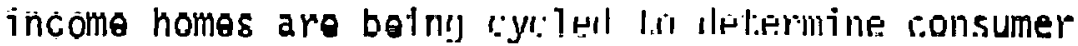
response, diversity as a function of temperature, demand reduction when units are cycled off at various lengths, and customer acceptance as a function of incentive.

FUNCTION: Cycling of air conditioner compressors and electric water heaters.

EQUIPMENT: Scientific Atlanta and Fisher Pierce radio load switches.

SAMPLE: $\quad 60,000$ residential customers by 1982.

INCENTIVE: $\quad \$ 8, \$ 6, \$ 4$, or $\$ 2$ per month, May through September.

MONITORING: Pole-top magnetic tape metering on selected feeder sections. Magnetic tape metering on 1,200 homes measuring water heating, air conditioning, and total house loads. Solid-state load proftle metering on 300 hümies.

INTERV IEW

DATE:

September 12, 1980. 
STATUS: $\quad$ Experiment continuing through December 1982.

RESULTS: $\quad 1977$ and 1978 reports are available. 
PRINCE WILLIAM ELECTRIC COOPERATIVE

10323 Lomond Drive

Manassas, Virginia 22110

Wm. Ray Gosney, Jr., Engineering Services Manager

SYSTEM:

SUMMARY:

FUNCTION:

\section{EQUIPMENT:}

Scientific Atlanta digital and Fisher Pierce two-tone sequential radio switching load management system. An Advanced Control Systems supervisory control/data acquisition system, monitoring 27 substations for kW demand to initiate load management, has been installed.

SAMPLE: $\quad 5,000$ residential units presently installed; Prince William Electric plans to add 5,000 additional points by January 1981 and expand to 15,000 by 1982 .

INCENTIVE: None. Rates will be reviewed and may be adjusted during 1981-1982 period, based on the results obtained. 
MONITORING: Monitor total kW demand at each wholesale power delivery point.

INTERVIEW

DATE :

Apri1 25, 1980.

STATUS: Installation begun in early 1979. Long-term project, in use systemwide and expanding annually.

RESULTS: $\quad$ Not yet available. Expect system to operate (turn off loads) an average of ten times per month in summer, five times per month in fall, six times per month in winter.

REMARKS: The main purpose of the project is to reduce the ratchet on peak purchased power costs. Prince William Electric pays $75 \%$ ratchet on power purchased from Virginia Electric and Power Company and estimates that $30 \%$ of its purchased power costs are the result of the demand ratchet. Winter and summer peaks are generally within 2-3\% of each other, so Prince William Electric expects year-round savings. Prince William Electric, since it is Virginia Electric and Power Company's second largest customer, is planning to install a data link with Virginia Electric and Power Company to ensure that times of peak load are coordinated. 
SAN DIEGO GAS \& ELECTRIC COMPANY

P.0. Box 1831

San Diego, California 92112

(714) $\frac{\text { NEW } 1980}{232-4252}$

John A. Roy, Project Manager, Load Management

SYSTEM: $\quad$ Radio

SUMMARY: A two-year project, starting September 1980, will test and evaluate load management on approximately $8 \%(7,200)$ of San Diego Gas \& Electric Company's identified residential central air conditioners and a select group of residential electric: water haters.

FUNCTION: Cycle central air conditioners and electric water heaters.

EQUIPMENT: $\quad$ Scientific Atlanta radio system.

SAMPLE: $\quad \quad 7,200$ residential central air conditioners, 425 residential electric water heaters.

INCENTIVE: $\quad$ Three levels - no incentive, $\$ 25 /$ year and $\$ 50 /$ year.

INTERV IEW

DATE : $\quad$ JuTy 9, 1980.

MONITORING: Magnetic tape metering.

STATUS: $\quad$ Planned to start September 1, 1980.

RESULTS: $\quad$ Not yet available.

REMARKS: $\quad$ This is a California Energy Commission mandated program. 
SAN DIEGO GAS \& ELECTRIC COMPANY

NEW 1980

P.0. BoX 1831

San Diego, Californja 92112

(714) $232-4252$

Thomas D. Stickels, Project Manager, Load Management

SYSTEM: $\quad$ Radio

SUMMARY: A three-year project, starting in May 1981, to test and evaluate load management in the commercial sector. Five Standard Industrial Classification (SIC) codes that have high air conditioning load to total load ratios have been selected. A sample of 250 customers will be selected, 50 from each of five SIC codes, and equipment will be installed to cycle air conditioning/refrigeration equipment. The objective will be to determine if load management is cost effective for a given SIC code. On those SIC codes that are cost effective for load management, efforts will be made to sign up as many additional customers as possible.

FUNCTION: $\quad$ Cycle air conditioning and refrigeration equipment.

EQUIPMENT: $\quad$ Scientific Atlanta radio system.

SAMPLE: $\quad 50$ customers from each of five Standard Industrial Classification (SIC) codes, totaling 250.

INCENTIVE: $\quad \$ 1.50 / \mathrm{kW}$ of connected load.

MONITORING: $\quad$ Mag tapes on equipment controlled.

INTERV IEW

DATE:

July $9,1980$.

STATUS: $\quad$ Planning customer contacting to start September 1, 1980. RESULTS: $\quad$ Not yet available. 
SOUTHERN CALIFORNIA EDISON COMPANY

P.0. Box 800

Rosemead, California 91770

E.A. Myers, Jr., Vice President

SYSTEM:

SUMMARY:

The Automatic Powershift systemwide test will be conducted among 2,250 randomly selected customers in eight districts in the Edison system. The objective is to obtain specific $\mathrm{kW}$ demand redurtion and to gather information on voluntary customer acceptance.

FUNCTION: $\quad$ Remotely cycle central air conditioners. Various samples have been set up for $25 \%, 33 \%, 50 \%$, and $66 \%$ control.

EQUIPMENT: $\quad$ Scientific Atlanta DES 1090 single-function FM radio switch.

SAMPLE: $\quad 2,250$ customers. 1ocated within five weather zones -super hot, very hot, hot, moderate, and mild.

INCENTIVE: $\quad$ Three rates are being used: one with no incentive, and the other two with a $\$ 3$ and $\$ 6$ per ton per year monthiy bill credit.

MONITORING: $\quad 540$ customers will have installed 5-minute integrated demand magnetic tape recorders measuring the entire household load.

INTERV IEW

DATE:

May 2, 1980.

STATUS: $\quad 1980$ testing to begin May 19, 1980. 
RESULTS: $\quad$ A March 1980 prel iminary report has been prepared on 1979 results. 
TENNESSEE VALLEY AUTHORITY

NEW 1980

210 Power Building

Chattanooga, Tennessee $37401^{\circ}$

(615) $755-3591$

Patricia H. Harris, Chief, Load Management Branch

SYSTEM: $\quad$ Radio

SUMMARY: Tennessee Valley Authority, on a voluntary basis, will install, at its own expense, radio-activated control switches on the existing central air conditioners or heat pumps of 50,000 consumers. An additional 50,000 consumers will have a control

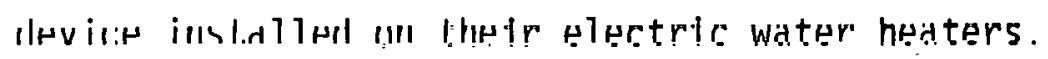

TVA dispatchers will cycle air conditioner compressors off for 7-1/2 minutes per half hour and water heaters for up to four hours.

FUNCTION: $\quad$ To cycle air conditioners, heat pumps, and electric water heaters during peak periods, allowing system operators to minimize production costs.

EQUIPMEN1: $\quad$ Motorola 23120 (two-function digital system).

SAMPLE: $\quad$ Fifty-thousand installations in about ten participating power distributor territories for air conditioner cycling, and 50,000 installations in the same distributor's areas for water heater cycling.

INCENTIVE: $\quad \$ 5$ per month credit on June through September electric bills for air conditioner cyciing, \$2 per month yearround for water heater cycling.

INTERVIEW

DATE: January 19, 1981. 
STATUS: Underway; 50,000 volunteers to be enrolled by 1983; approximately 6,000 consumers enrolled to date.

RESULTS: $\quad$ Not yet determined. 
TENNESSEE VALLEY AUTHORITY

210 Power Building

Chattanooga, Tennessee 37401

REV ISED 1980

(615) $755-3591$

Patricia H. Harris, Load Management Branch

SYSTEM: $\quad$ Radio

SUMMARY: This two-year water heater control project involves 457 residential customers with conventional water heaters. In addition, 100 all-electric customers will be provided with an energy-efficient, 120-gallon, off-peak water heater. The consumers in this test have been selected from four Tennessce Valley Authority power dislribulur's' dreds covering the broad range of climatic variation and two time zones under the Tennessee Valley Authnrity system. The four communities are:

$$
\begin{aligned}
& \text { Cleveland, Tennessee } \\
& \text { Huntsville, Alabama } \\
& \text { Jackson, Tennessee } \\
& \text { Tri-County EMC }
\end{aligned}
$$

FUNCTION: $\quad$ Control standard and 120-gallon residential water heaters; cycle residential air conditioners and/or heating systems.

EQUIPMENT: All water heater and space conditioning equipment controls will be effected using the Motorola $800-W$ radio system or the English Electric Corporation cyclocontrol signal injection system. (See cyclocontrol project -- Tri-County EMC.)

SAMPLE: $\quad$ Project involves a total of 457 residential customers in four communities, most of which will involve radio control and 20 of which will involve the cyclocontrol system.

INCENTIVE: The financial incentives to participate in this test are: 
(1) For control of existing water heaters: $\$ 25$ initially/ $\$ 25$ at end of test period;

(2) For control of existing water heaters and conventional space conditioners: \$45 initially/ $\$ 45$ at end of the test; and

(3) For control of existing water heaters and heat pumps: $\$ 65$ initially/ $\$ 65$ at the end of the test.

MONITORING: A11 457 installations are being submetered using a metering package consisting of: one General Electric four-track magnetic tape recorder, and three watthour meters, selected by the local distributor, equipped with pulse initiators to track the energy use in the controlled water heater, controlled space conditioning, and appliances to be monitored.

INTERV IEW

DATE :

April 28, 1980.

STATUS: In service.

RESULTS: Data reduction in progress.

REMARKS: $\quad$ Participation in this test is entirely voluntary. Overall consumer acceptance of the equipment has been positive regarding water heater and air conditioning control. Space heating participants were somewhat more difficult to obtain. 
WABASH VALLEY POWER ASSOCIATION

$700 \mathrm{~N}$. High School Road

Indianapolis, Indiana 46224

NEW 1980

Ron Hale, Manager of System Operations

(317) $247-1596$

SYSTEM: $\quad$ Radio

SUMMARY: $\quad$ Based on the results of a successful 130-point pilot program, Wabash Valley Power Association has finalized plans to implement a large-scale program of water heater control among its 24 member cooperatives. Wabash Valley Power Association will provide radio swit.r.hes to it.s memher cooperatives along with $\$ 20$ per switch (subject to increase, if insufficient) to defray costs of installation. Each of the cooperatives will then utilize its own control and transinitting equipment to cycle residential water heaters off up to four hours during peak periods, in an attempt to reduce billing demand.

FUNCTION: To cycle residential water heaters during periods of peak demand.

EQUIPMENT: Motorola transmitters and receivers.

SAMPLE: Available to all residential water heating customers served by 24 distribution cooperatives. Program is expected to involve 20,000 water heaters by the winter of 1980-81 and 50,000 within 3 years.

INCENTIVE: None.

INTERV IEW

DATE:

November 13, 1980

STATUS: Equipment on order.

RESULTS: $\quad$ Not yet determined. 


\subsection{RIPPLE}

Technical Characteristics

Ripple systems have been in use for many years in Europe and other parts of the world as unidirectional C\&LC systems that perform control functions at the customer location on command from the utility. In use for over 35 years in Europe, ripple control systems have built up a reputation for reliability. It is estimated that, worldwide, more than 120 gigawatts of installed system capacity, or about $10 \%$ of the world's total generating capacity, is under ripple control.

A ripple control system utilizes a utility's transmission or distribution system as the medium for transmitting signals. A typical unidirectional ripple C\&LC system operates in the following manner:

- Utility system data is fed into a computer-based central control unit. The data is analyzed and compared to previously entered system parameters, such as load level, ambient temperature, and rate of load increase. When the analyzed system data exceeds these trip parameter setpoints, the central controller will issue preprogrammed commands that are encoded and then sent to a ripple transmitter site via a telemetry link.

- When the transmitter is located at a site other than the controller, which is typical, the transmitter uses a remote control unit (RCU) to interpret the central control commands. The RCU is basically an interfacing device between the central controller and the transmitter.

The transmitters are audio frequency generators and amplifiers that provide audio frequency signal power for injection into the utility network.

The audio frequency signals are superimposed on the normal $60-\mathrm{Hz}$ line voltage sinewave by the injection transmitter. These audio signals are typically in the frequency range of 200 to $1,500 \mathrm{~Hz}$, with an amplitude of 0.1 to $1.0 \%$ of the supply voltage amplitude. Normal line noise is relatively high at 
these frequencies, requiring the pulse to be of a large enough amplitude to maintain an acceptable signal-to-noise ratio.

The impulses generated by the transmitter are injected into the utility system in preset code patterns. The signal is propagated long distances over the utility's lines with little attenuation because of its low operating frequency.

- The impulises are detected by the receiver and decoded (interpreted). The receivers are preprogrammed to respond only to certain signals; all other signals are ignored. If the signal is accepted by the receiver, it activates an output relay to switch off a load, activate a local controller, or perform some other customer site function. The receivers may function alone or in groups, depending on their program codes. Receivers can be either electronechanical or solid state.

A typical ripple C\&LC system can be used to control loads such as water heaters, air conditioners, space heating circuits, and irrigation pumps. It can perform automated distribution functions, such as capacitor switching or line switching, and can be used in conjunction with on-site local logic controllers or energy storage systems.

Ripple is generally considered to be a unidirectional system, but some available hardware has bidirectional capability. A bidirectional ripple system is capable of remotely reading meters, confirming switching functions, and alerting central controllers to selected occurrences.

\section{System Costs}

The key components of a ripple control system are essentially the same as those found in a radio control system - the central control, transmitter, and receiver/switch. As such, it would be expected that the per point cost of a ripple control system would be governed by the same types of relationships as those developed for a radio control system. Since a ripple transmitter is capable of controlling any number of receivers, limited only to the number of controllable points on the distribution lines under the influence of the transmitter, the per point cost of a 
ripple control system ought to be inversely proportional to receiver saturation. Thus, the total per point cost a utility might expect to pay for a ripple control system would be chiefly governed by the installed cost per receiver at high saturation levels. At lower saturation levels, the installed costs of the injection transmitters, central control system, and related hardware play a larger role in determining the total system per point cost. As a first step in determining the "typical" per point cost a utility might expect to pay for a ripple system, quotations on equipment costs were acquired from three major manufacturers of ripple control systems.

Manufacturer A - The cost of a microprocessor-based central control station ranges from $\$ 25,000$ to $\$ 40,000$. Substation injection units cost from $\$ 1,250$ to $\$ 1,750$ per MVA of substation capacity. Ripple receivers cost $\$ 65$ for 2-ampere models and $\$ 80$ for 25-ampere models.

Manufacturer B - The costs of a central control unit range from $\$ 12,000$ to $\$ 60,000$, depending upon the levels of sophistication and redundancy required. Single-function, electromechanical receiver switches cost $\$ 98$ each. Solid-state single-function receiver switches cost $\$ 112$ each. Manufacturer C - A microprocessor-based central control unit sells for $\$ 15,000$. The bidirectional communication links (telemetry) between central control and the injection points are estimated at $\$ 3,000$ to $\$ 4,000$ per injection point if such links are not already a part of the utility's system. The injection equipment at each point typically costs $\$ 1,500$ per MVA of installed capacity at that point. Costs per MVA are lower at large capacity stations and higher at small capacity stations. The basic single-function receiver costs $\$ 85$. Up to three additional functions (total 4) may be added to the receiver at an incremental cost of $\$ 25$ per function.

In the section dealing with radio system rosts, it was assumed that all receiver switches were of the standard address single-function type. Ripple systems employ a more complex addressing format than radio systems, and are more adaptable to multifunctional use (switching more than one load per receiver). As such, many of the ripple receivers in use today 
have multifunctional capabilities. The average cost of this type of switch, based on manufacturers! quotations, is $\$ 88$.

In order to determine the ranges of per point installed costs actually incurred by utilities equipped with ripple systems, a series of interviews with utility personnel were conducted, and several utility project reports were examined.

Minnkota Power Cooperative is the wholesale electric power supplier for twelve rural electric coops located in North Dakota and Minnesota.

Minnkota Power Cooperative has committed itself to a systemwide ripple control program and projects that over 11,000 rereiver switches will soon be inst.allest.

The installed costs for the Minnkota ripple control system are summarized in Table 2-5.

\section{Table 2-5 \\ MINNKOTA POWER RIPPLE SYSTEM INSTALLED COSTS}

\begin{tabular}{|c|c|c|c|}
\hline & Each & Required & Total \\
\hline $\begin{array}{l}115 \mathrm{kV} \text { injection } \\
69 \mathrm{kV} \text { injection } \\
\text { Neutral injection } \\
\text { Central control }\end{array}$ & $\begin{array}{l}\$ 400 \mathrm{~K} \\
\$ 238 \mathrm{~K} \\
\$ 75 \mathrm{~K} \\
\$ 500 \mathrm{~K}\end{array}$ & $\begin{array}{l}4 \\
8 \\
4 \\
1\end{array}$ & $\begin{array}{l}\$ 1.6 \mathrm{M} \\
\$ 1.9 \mathrm{M} \\
\$ 0.3 \mathrm{M} \\
\$ 0.5 \mathrm{M} \\
\end{array}$ \\
\hline \multicolumn{3}{|c|}{ Injection equipment total } & $\$ 4.3 \mathrm{M}$ \\
\hline Receivers & $\$ 160$ & 11,000 & $\$ 1.8 \mathrm{M}$ \\
\hline Totàl system & & & $\$ 6.1 \mathrm{M}$ \\
\hline
\end{tabular}

Of the $\$ 160$ receiver cost shown in Table $2-5, \$ 80$ represents the cost of the receiver itself and $\$ 80$ represent.s it.s average installation cost. The total system cost of $\$ 6.1 \mathrm{M}$ translates to a total installed per point cost of slightly more than $\$ 554$ assuming the installation of a 1111,000 receiver/switches.

This seemingly high per point cost can be explained by examining the cost elements themselves. $\$ 394$ of the $\$ 554$ per point cost figure represent 
the apportioned per point installed costs of the central control, telemetry, and injection equipment. Although this apportioned figure would be expected to drop dramatically as receiver saturation increased, it would still represent the major single per point cost element for receiver saturation levels below 53,000 points.

The high front end costs which Minnkota experienced in the development of its ripple system are primarily attributable to the need to cover an extremely largè service area. Minnkota's service area encompasses 35,000 square miles $(90,600 \mathrm{~km}$ square), an area roughly the size of the state of Indiana. The need to effectively cover such an area and still maintain total and reliable signal penetration required a large investment in high-powered injection equipment.

Another factor that significantly affects the high per point cost in the Minnkota ripple system is the reported $\$ 80$ cost for installing each receiver switch. Of the $\$ 80$ reported, $\$ 25$ reflects the true cost of the installation of the switch itself (\$15 labor and $\$ 10$ for a switch enclosure). The remaining $\$ 55$ reflects Minnkota's estimated cost for promoting ripple control and making customer contracts. Although this $\$ 55$ is certainly a real and valid cost in the accounting sense, it represents more of an administrative or operating cost than an installed equipment cost. These types of costs, which would be expected to be common, in varying degrees, to all utility projects, have not been considered within the scope of this analysis.

It is significant to point out that, in spite of its high per point costs, the Minnkota ripple control system has proven to be extremely cost effective. The major thrust of Minnkota's load management program has been the installation and control of dual fuel heating systems. This type of load control has offered Minnkota an average 10-kW load relief per point. Thus the $\$ 554$ per point cost figure relates to a much more acceptable $\$ 55.40$ per $\mathrm{kW}$.

While the Minnkota system has proven to be extremely cost effective thus far, it can hardly be viewed as a typical system. The high per point 
costs exhibited, which are a function of a large service area with a low population density, are offset by the high value of the loads controlled. Green Mountain Power Company is involved in a ripple demonstration project utilizing 300 receiver switches, all of which are located along the lines of one distribution substation. The ripple signals are injected at the substation on the $12-\mathrm{kV}$ side and the presently installed injection and control equipment has the capability of controlling the entire substation service area. The costs of the Green Mountain ripple system have been reported as follows. Receivers cost $\$ 97.44$ each, with an average installation cost of $\$ 15$ each. The total equipment costs of the injection equipment, central control, and receivers amounted to slightly over $\$ 100,000$. Adding in the cost of installing all the equipment, brings the total system installed cust to approximately $\$ 134,500$ which, for 300 receivers, translates to a present per point cost of $\$ 448$. Since this is an experimental project involving relatively few points, the present per point cost is not significant. This per point cost can be extrapolated, however, based on increasing levels of receiver saturation, within the capability constraints of the existing injection and control equipment. Such an extrapolation can offer a clearer picture of potential ripple per point costs. Table 2-6 graphically shows this type of cost extrapolation.

Although it is difficult to predict what the maximum expected receiver saturation would be on this particular substation, Table 2-6 shows that as the receiver saturation approaches 3,000 , the total per point cost drops below $\$ 150$. This point is significant because Green Mountain Power has estimated that, with a systemwide ripple control system, they would expect to see a total per point cost of $\$ 150$. This $\$ 150$ per point total cost figure also falls into that area of the curve beyond which only marginal benefits are realized by the addition of more receivers (sensitivity change). 


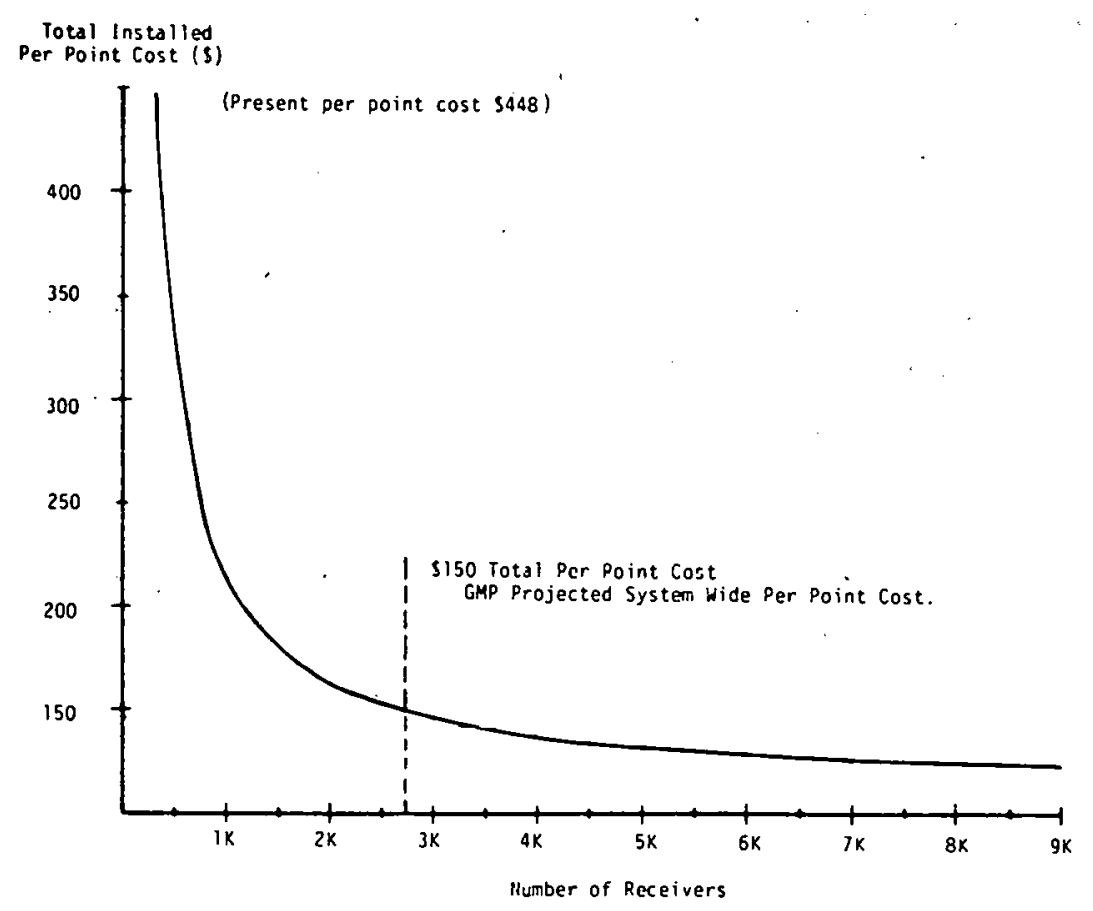

Table 2-6. Green Mountain Power Ripple Control Total Per Point Cost as a Function of Receiver Saturation

The Green Mountain system, in this extrapolated form, would be expected to more closely resemble a typical ripple control system than would the Minnkota system, since Green Mountain Power does not suffer the implications of an extremely low population density. The identified total perpoint cost of $\$ 150$, however, must be viewed in the perspective of several factors. As with any communication and load control system, the final total per point cost is greatly influenced by the circumstances found in any one particular utility's network system.

The Marietta (Georgia) Board of Lights and Water Works has invested $\$ 295,000$ in a ripple control system that involves 2,584 switches. This yields a total per point cost of $\$ 114$. Th1s $\$ 114$ may be brukenl duwil as follows: the dual-function receiver switches cost $\$ 58$ each; the average installation cost per receiver switch was $\$ 11$; and the remaining $\$ 45$ 
represents the apportioned per point installed cost of signal injection equipment and central control.

The wide ranges of per point costs for ripple control ( $\$ 114-\$ 150-\$ 554)$ derived in these examples demonstrates that the determination of a typical cost is more difficult for ripple control than for radio. One reason for this range of costs is that most ripple hardware is manufactured overseas (France, Germany, etc.) and its prices are subject to foreign exchange fluctuations, as well as inflation.

The costs that utilities can expect to see in the near future may very well be lower, since at least two foreign manufacturers have established production facilities in the United States. 
Ripple Control Equipment Manufacturers

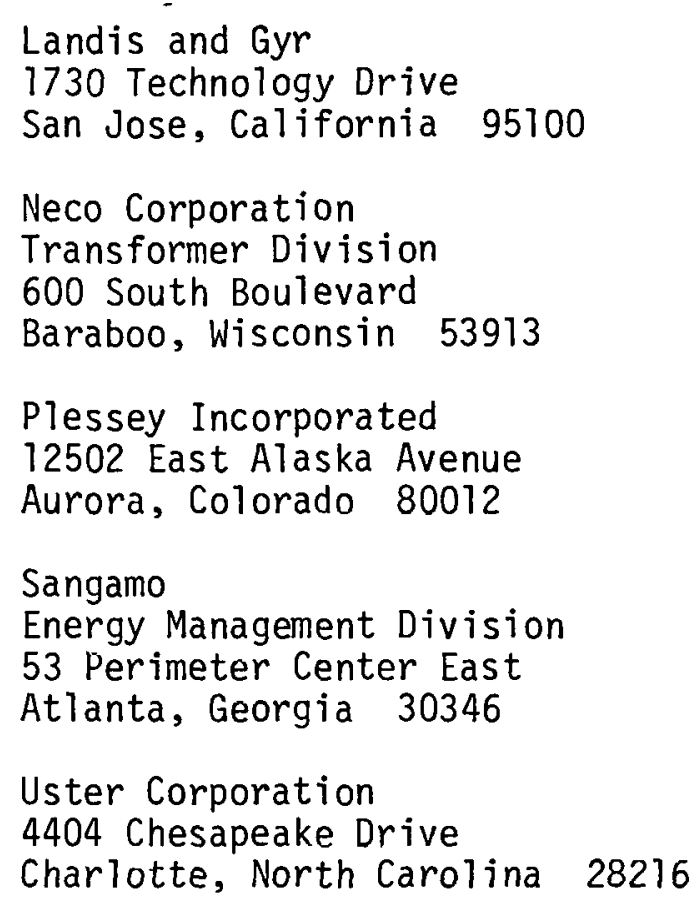


$2-78$

THIS PAGE

WAS INTENTIONALLY

LEFT BLANK 
Table 2-7

Ripple Control Project Sumary

\begin{tabular}{|c|c|c|c|c|c|c|c|c|c|}
\hline Utility & Contact & Equi ipment & $\begin{array}{c}\text { Control } \\
\text { Eunnction(s) }\end{array}$ & $\begin{array}{l}\text { Number } \\
\text { of Points }\end{array}$ & class & $\underline{\text { Status }}$ & Incentive & Results/Remarks & Contact Date. \\
\hline $\begin{array}{l}\text { Central Vermont Public } \\
\text { Service }\end{array}$ & 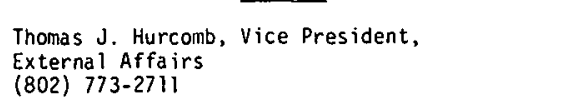 & 186 & TES-WH-MR-DA & 1,600 & Demonstration & In service & None & $\begin{array}{l}\text { Excel lent signal propogation. } \\
\text { Considering expans ion. }\end{array}$ & May 19, 1980 \\
\hline Consol idated Edison & $\begin{array}{l}\text { Arnold Rosenthal, Oirector, Load } \\
\text { Management } \\
(212) 460-6624\end{array}$ & u & $\begin{array}{l}\text { LC in two } \\
\text { buildings }\end{array}$ & 1,601 & Two buildings & In service & Monthly demand billing & Daily savings $5 \%-50 \%$. & May 1, 1980 \\
\hline Consumers Power & $\begin{array}{l}\text { Thonas L. Goul ish, Manager, Energy Consulting } \\
\text { Services } \\
\text { (517) 788-0550 }\end{array}$ & $\mathrm{s}$ & WH-AC-SH & 150 & Demonstration & Completed & $\$ 2 /$ month/controlled load & Data being anal yzed. & April 29, 1980 \\
\hline $\begin{array}{l}\text { Fairmont Public Utilities } \\
\text { Commission }\end{array}$ & $\begin{array}{l}\text { L.EE E. Madsen, Manager of Utilities } \\
(507), 235-6691\end{array}$ & $\mathrm{~s}$ & AC-AH & 1,650 & Systemwide & In service & Mone & $\begin{array}{l}2500 \mathrm{~kW} \text { 'load resuction summer } \\
\text { of } 1980 .\end{array}$ & November 4, 1980 \\
\hline $\begin{array}{l}\text { Fort valley Utilities } \\
\text { Comnission }\end{array}$ & $\begin{array}{l}\text { Fred Sankey, irectior or Utili ities } \\
(912) \text { 825-7701 }\end{array}$ & $\mathrm{s}$ & $A C$ & 1,500 & Systemwide & in service & None & $\begin{array}{l}\text { 3.M M load reduction sumer } \\
\text { of } 1980 \text { : }\end{array}$ & November 3, 1980 \\
\hline Georgia Power Company & $\begin{array}{l}\text { Oon 6. Sabin, Manager, Energy Ressaarch } \\
\text { (404) } 522-6060\end{array}$ & s & AC. & 300 & Demonstration & In service & None & N/A & Juily 24, 1980 \\
\hline Grant Electric Cooperative & $\begin{array}{l}\text { Aarvey Mel 15, Equipment Technician } \\
(608) 723-2121\end{array}$ & N & WH & 325 & Systemwide & $\begin{array}{l}\text { Partiallyy } \\
\text { in service }\end{array}$ & None & $1 \mathrm{~kW}$ reduction per $\mathrm{WH}$. & November 12, 1980 \\
\hline Green Mounta in Power & $\begin{array}{l}\text { Henry A. Boisse, Director of Marketing } \\
\text { (802) 864-5731 }\end{array}$ & u & WH-SH & 350 & Oemonstration & In service & $\$ 5 /$ month//HH & $\begin{array}{l}\text { Considering pxpansion. Final } \\
\text { report available. }\end{array}$ & April 29, 1980 \\
\hline $\begin{array}{l}\text { Mari iette Board of Lights } \\
\text { and water Works }\end{array}$ & $\begin{array}{l}\text { Ed Hoback, Consuncr Representative } \\
(404), 429-4249\end{array}$ & $\mathrm{~s}$ & Ar. & 3.500 & Sys temvide & In service & None & First year savings of $\$ 300,000$. & November 3, 1980 \\
\hline $\begin{array}{l}\text { Marshall Municipal } \\
\text { Utilities }\end{array}$ & $\begin{array}{l}\text { Layt Ausen, Operator } \\
\text { (507) } 532-21145 \text { r tor }\end{array}$ & s & WH-AC-SH & 1,000 & Systerwide & $\begin{array}{l}\text { Partially } \\
\text { in service }\end{array}$ & None & N/A & November 12, 1980 \\
\hline Minnkota Power & $\begin{array}{l}\text { Melvin D. Ne lson, Supervising Engineer, } \\
\text { System Operations } \\
(701) 795 \text { - } 4000\end{array}$ & $\angle 86$ & DHS & 15,000 & Sys termwide & In service & Typical savings $-1.54 \mathrm{kwh}$ & Project $60 \mathrm{MW} \mathrm{of} \mathrm{load} \mathrm{reduction.}$ & May 18, 1980 \\
\hline $\begin{array}{l}\text { New Or leans Public } \\
\text { Service }\end{array}$ & $\begin{array}{l}\text { Arthur Mott, Supervisor, Technical Services } \\
(504)_{586-2246}\end{array}$ & $S / A$ & AC-HH-SH & 200 & Demonstration & In service & Monthly allowance & $N / A$ & September 12,1980 \\
\hline $\begin{array}{l}\text { Norcross Municipal Light } \\
\text { Departrnent }\end{array}$ & $\begin{array}{l}\text { Doug hood, Superintendent, Electric } \\
\text { Deeartrent } \\
(404) \text { 448-2112 }\end{array}$ & $\mathrm{s}$ & $A C$ & 800 & Systemwide & In service & None & $N / A$ & November 3, 1980 \\
\hline $\begin{array}{l}\text { Northern States Power } \\
\text { Company }\end{array}$ & $\begin{array}{l}\text { Conrad J. Aas, Admini istrator, Research } \\
\text { Progorams } \\
(617) \text { 330-5766 }\end{array}$ & L\&G & $A C$ & 25 & Demonstration & $\begin{array}{l}\text { Partially } \\
\text { in service }\end{array}$ & None & $\begin{array}{l}\text { Us ing Minnkota's signalling } \\
\text { sysctull. }\end{array}$ & August 14, 1980 \\
\hline $\begin{array}{l}\text { Public Service Electric } \\
\text { and Gas }\end{array}$ & $\begin{array}{l}\text { Fred Thurkauf, Manager, Load Management } \\
\text { (201) 430-6890 }\end{array}$ & $\angle 86$ & $A C-\mathrm{WH}$ & 250 & Demonstration & In service & $\begin{array}{l}\$ 4 / \text { month/AC }-4 \text { months; } \\
\$ 2.50 / \text { month } W H-12 \text { months }\end{array}$ & Report due fall 1980. & May 2, 1980 \\
\hline $\begin{array}{l}\text { Thief River Falls watar } \\
\text { and Lighe Department }\end{array}$ & $\begin{array}{l}\text { Arlo. Rude, Distribution Engineer } \\
(218) 681-5816\end{array}$ & $\mathrm{~s}$ & WH-SH & 192 & Systemwide & $\begin{array}{l}\text { Partially } \\
\text { in service }\end{array}$ & Special control rates. & N/A & Novenber 3, 1980 \\
\hline United Power Association & $\begin{array}{l}\text { Vince Zenringer, Project Manager } \\
\text { (612) } 441-31211\end{array}$ & s & WH-SH & 160 & Demonstration & In service & None & N/A & September 4, 1980 \\
\hline Utah Prower and Light & 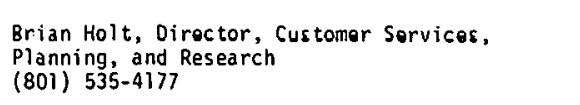 & L8G & AC & $5 n$ & Demnnstratition & In service & None & $\begin{array}{l}\text { Project, ending. Rel iabil i ty } \\
\text { good. }\end{array}$ & August 13, 1980 \\
\hline Vernon Electric Cooperative & $\begin{array}{l}\text { Earl Jaeger, Manager } \\
(608) \text { 634-3i21 }\end{array}$ & N & wh & 4,700 & Systemvide & in service & Spectal rate & $\$ 400,000$ antrual saviliys. & April 29, 1980 \\
\hline
\end{tabular}


THIS PAGE

WAS INTENTIONALLY

LEFT BLANK 
Table 2-7 (Continued)

\begin{tabular}{|c|c|c|c|c|c|c|c|c|c|}
\hline veility & Contact & iquigrent & $\begin{array}{l}\begin{array}{c}\text { Control } \\
\text { function }\end{array} \\
\end{array}$ & 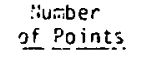 & Class & Status & In:encive & 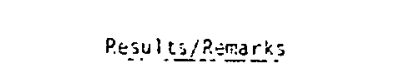 & Contact oats \\
\hline $\begin{array}{l}\text { nia Electric and Power } \\
\text { ny }\end{array}$ & $\begin{array}{l}\text { Ed wicknam, Director, Load Managenent } \\
\text { appopications } \\
\text { (804) } 771-3351\end{array}$ & $\mathrm{~s}$ & WH & 1,000 & Demonstration & In service & $\$ 1.85 /$ month/ $/ \mathrm{WH}$ & Technical evaluation completed. & July 14, 1980 \\
\hline $\begin{array}{l}\text { nia Electric and Power } \\
\text { ny }\end{array}$ & $\begin{array}{l}\text { Ed hickham, Director, Load Management } \\
\text { AAplicictions } \\
(804) \text { 771-3351 }\end{array}$ & $\mathrm{s}$ & WH & 5,000 & $\begin{array}{l}\text { Territorywide } \\
\text { in } \begin{array}{l}\text { North } \\
\text { Carol ina areas }\end{array}\end{array}$ & Planning & $\$ 1.85 /$ month/wH & $N / A$ & July 15, 1980 \\
\hline $\begin{array}{l}\text { Memphis Utility } \\
\text { tment }\end{array}$ & $\begin{array}{l}\text { Joryn } \begin{array}{l}\text { Smith, Electrical Superintendent } \\
\text { (501) } 735-3355\end{array}\end{array}$ & $\mathrm{~s}$ & AC & 1,800 & Systemwide & In service & $\begin{array}{l}\$ .50 / \mathrm{kW} \text { credit } \\
\text { through August }\end{array}$ & $2051 \mathrm{~kW}$ load reduction. & April 28, 1980 \\
\hline 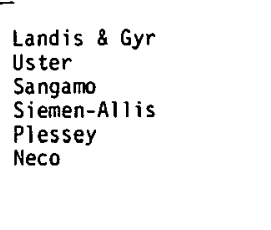 & 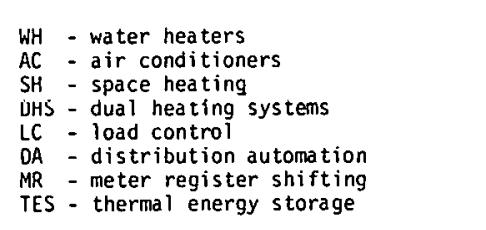 & & & & & & & - & \\
\hline
\end{tabular}


THIS PAGE

WAS INTENTIONALLY

LEFT BLANK 
CONSOLIDATED EDISON COMPANY

4 Irving Place

New York, New York 10003
REV ISED 1980

(212) $460-6539$

Dennis P. Quirk, Assistant Vice President, Conservation Services

Stephen A. Pertusiello, Utilization Engineer

SYSTEM: . $\quad$ Ripple - Apartment Building

SUMMARY: In a new 800-unit apartment building, a Uster Ripple System controls apartment and public area heating, cooling, and ventilation loads for reduction of monthly utility demands on a master metered rate. Some reduction in energy use also helps reduce monthly bills. Funding of the system is by builder and owner, and monitoring is by Consolidated Edison Company. Detailed tenant demographic and appliance profiles are being kept.

EQUIPMENT: Uster Ripple and Computer System located within the building with battery-powered backup.

FUNCTION: $\quad$ Seasonally-programmed computer injects a signal into the building wiring that activates dual-switch receivers in 800 apartments and other building areas to separately cycle air conditioning compressors and fans, resistance space heating, kitchen and toilet exhaust fans, swimming pool, tennis court, and main corridor heating and ventilating systems at set intervals. Tenants have option of two-hour override without penalty, and elderly and infirm are exempt.

SAMPLE: $\quad 800$ apartments in one of two new twin-tower buildings in Manhattan occupied $80 \%$ by people in the theater trade and $20 \%$ by former local neighborhood people. 800 apartments in other tower are being monitored for comparison. Tenant demographic and appliance ownership profiles are 
maintained.

INCENTIVE: To control monthly billing demand on master metered rate and also save on energy charge. Apartment house TOD rate that would apply is filed, but not approved. Hours are 8 a.m. to 6 p.m., Monday through Friday, May through September. No incentive to tenants, but control over their heating, cooling, and ventilation is provided for in the original lease.

MONITORING: Consolidated Edison Company has installed magnetic tape recorders at three take-off points within each building.

INTERVIEW

DATE :

May 2, 1980.

STATUS: The system operated successfully in the first tower in 1978 and data will be gathered through 1980. Similar equipment has been installed in the second building, including a second computer. One computer is adequate for both buildings, but the second can be used to back up the first.

RESUII.TS: The analysis of the data for the first tower during the first winter shows daily savings from $5 \%$ to $50 \%$, depending on the severity of the outside temperature. The second tower data is now being analyzed.

REMARKS: $\quad$ Ripple system furnished and installed by the builder. Cooking and water heating is by gas. Control temperature is lower in bedrooms at night. 
GREEN MOUNTAIN POWER COMPANY

REVISED 1980

1 Main Street

Burlington, Vermont 05401

(802) 864-5731

Henry A. Boisse, Director of Marketing

SYSTEM: $\quad$ Ripple

SUMMARY: Using an Uster ripple system from a master control at Montpelier, a $280-\mathrm{Hz}$ signal is imposed on two $12-\mathrm{kW}$ feeders at South Burlington Substation to cycle 290 water heaters and disconnect 60 electric heating points in South Burlington High School on a rolling basis of 15 at a time for 15 minutes, resulting in a 25-percent demand reduction. The ripple system was selected over radio systems because of mountainous terrain that presents radio reception difficulties.

FUNCTION: $\quad$ Ripple system at $280 \mathrm{~Hz}$ switches off residential water heaters for up to four hours twice a day, and 25 percent of electric heating in a high school, as necessary.

EQUIPMENT: Uster Corporation ripple system. Bidirectional subsystem at the high school in conjunction with ripple master control.

SAMPLE: $\quad$ Three hundred water heater customers plus 100 electric heating circults in two South Burlington śchool buildings.

INCENTIVE: $\quad \$ 5.00$ per month credit on electric service bill.

MONITORING: Substation instruments only.

INTERV IEW

DATE:

April 29, 1980. 
STATUS: In service.

RESULTS: $\quad$ No operational or customer relations problems.

Final report is available.

REMARKS: Considering a 20,000-point systemwide installation at $\$ 130$ to $\$ 140$ per point. 
MINNKOTA POWER COOPERATIVE, INC.

REVISED 1980

P.0. Box 1318

Grand Rorks, North Dakota 58201

(701) $795-4000$

Melvin D. Nelson, Supervising Engineer, System Operations

SYSTEM: $\quad$ Ripple Control

SUMMARY: $\quad$ Annual load factor improvement up to at least $70 \%$ (from $45 \%$ in 1976) is expected by 1985, through the control of 15,000 residential and commercial dual heating installations via ripple. A high wholesale demand ratchet encourages member cooperatives to curtail peak load growth. In turn, retail rates for controlled service provide substantial incentives to member consumers to participate in this program. Off-peak heating rates are typically about $1.5 \$ / k W h$.

FUNCTION: To control three categories of load: (1) short term-water heaters and potato warehouses for up to 8 hours (4 hours typical); (2) medium term--slab storage electric space heating from 8 to 16 hours (12 hours typical); (3) long term--dual heating systems and standby generators for extended periods (400-600 hours annually).

EQUIPMENT: Landis \& Gyr ripple control system, twelve major injection points (four at $115 \mathrm{kV}$ and eight at $69 \mathrm{kV}$ ), fnur neutral injection points (at $12.5 \mathrm{kV}$ ). Microwave communication links the automatic central control equipment with the injection points.

SAMPLE: $\quad 5,000$ receivers, allocated to local co-ops on a member consumer basis in 1977, have been installed. 8,000 additional receivers were delivered in 1978 and another 2,000 were ordered. In the near future, 20,000 units will be in service. 
INCENTIVE: Minnkota Power Cooperative wholesale rate to the local cooperatives has a two-tier billing demand and a 100\% ratchet on coincidental peak. 1980 demand charges are $\$ 2.85 / \mathrm{kW}$ per month of historically allocated demand, plus $\$ 5.70 / \mathrm{kW}$ per month for excess demand at time of Minnkota Power Cooperative system peak, ratcheted for one year. Member cooperatives offer off-peak heating rates which can reduce heating costs by $40 \%$ for dual heating installations, as compared with straight oil heat or controlled electric heat. Some member co-ops offer low-interest loans and a $1.0 \$ / \mathrm{kWh}$ discount for controlled dual heating systems, and some will not allow new electric heating connections unless they are controlled.

MONITORING: Magnetic tape moters at 150 wholesale delfvery points.

INTERV IEW

DATE:

REMARKS:
STATUS:

May 15, 1980.

In service.

Mirnkota Power Cooperative supplies 12 member cooperàtives of 69,000 member connsumers in the castern 1/3 ur North Dakota and in northwestern Minnesota: Ripple was selected because of favorable economics, greater flexibility, and the need for 12 major injection sites as opposed to 30 transmitters for radio and 130 control sites for carrier current injection. Minnkota Power Cooperative and its members are aggressively promoting dual heating systems-electric of $i$-peak and oil on-peak. Minnkota Power Cooperative had 2,000 dual heating systems under control in winter 1979-80 and expects to add another 2,000 this coming year.

RESULTS: $\quad$ During the winter of 1979-80, Minnkota was able to shed $45 \mathrm{MW}$ or $12.5 \%$ of total load from peak, which improved 
annual load from $45 \%$ in 1976 to $57 \%$ in 1979. Minnkota Power Cooperative projects total load shed capability at 1980-81 peak will be $60 \mathrm{MW}$.

The conversion to dual heating from oil heating saves at least 1,000 gallons of $0 i 1$ per year by substitution of coal-derived off-peak electricity. One commercial installation, alone, displaced 206,000 gallons of fuel in 1979 with dual heating. Estimated savings of fuel in 1979-80 winter were 2.2 million gallons with 2,000 dual heating systems in service. By 1985, cumulative savings of oil will amount to at least 62 million gallons of $0 i 1$ -- a rather significant amount of oil conserved by a relatively sma 11 number of consumers. 
PUBLIC SERVICE ELECTRIC AND GAS COMPANY

80 Park Place

Newark, New Jersey 07101

REVISED 1980

Fred Thurkauf, Jr:, Manager, Load Management

Clark W. Gellings, Assistant Manager, Load Management

SYSTEM: $\quad$ Ripple

SUMMARY: In Leisuretowne Retirement Community, Vincentown, New Jersey, Public Service Electric and Gas Company has solicited the participation of 250 custonmers on a singlc distribution circuit in a two-year water hcating and air conditioning ripple control project. An additional 39 volunteers have been enlisted to act as a control group. A number of interruption schedules will be exercised to evaluate custumer response.

FUNCTION: To cycle water heaters and air conditioners according to a variety of schedules, and to quantify possible circuit relief and customer tolerance.

EQUIPMENT: Landis and Gyr ripple control system with controller and signal injection equipment located at Moorestown Electric Distribution facility.

SAMPLE: $\quad 250$ residential test volunteers of which 30 have mag tape metering, and 30 control group customers with mag tape metering.

INCENTIVE: $\quad \$ 4.00 /$ month for control of air conditioner (May-0ctober). $\$ 2.50 /$ month for control of water heater (12 months).

MONITORING: Meter 30 of the test homes and 30 control homes to obtain details of control. Meter distribution circuit to evaluate effects of control on circuit load, including tests to 
demonstrate capability of shedding all loads simultaneously under system emergency conditions.

INTERV IEW

DATE:

STATUS:

RESULTS:

REMARKS:
May 2, 1980.

Test in progress.

Not available at this time.

In 1981 an additional 60 customers plus 65 control customers, all with central air conditioners and on a single distribution circuit, will participate in an additional ripple project to demonstrate load shedding simultaneously under system emergency conditions. Also, fifteen Honeywell "Smart Thermostats" will be installed in fifteen homes in Leisuretowne to increase thermostat settings to as high as $82^{\circ} \mathrm{F}$ on ripple command. 
UNITED POWER ASSOCIATION

NEW 1980

Elk River, Minnesota 55330

(612) $441-3121$

Vance Zehringer, Project Manager

SYSTEM: $\quad$ Ripple

SUMMARY: Using the Sangamo ripple system, United Power Association is testing the peak shaving concept of load management. In 160 homes, water heaters will be cycled off for up to 4 hours centering on their 6:30 p.m. winter peak. Unitcd Power Association expects to have one of evcry five waler heaters on during any 4-hour control perind. Also, in 10 humes, baseboard space heating will be cycled using Sangamo's Heat Cycler system in conjunction with ripple control.

FUNCTION: To cycle water heaters during winter peak hours in 160 homes and baseboard heating in 10 homes all on one feeder from one substation.

EQUIPMENT: Sangamo ripple system. Sangamo Heat Cycler system.

SAMPLE:, $\quad 160$ residential consumers.

INCÉNTIVE: None.

MONITORING: Substation kW and power factor meters only.

INTERVIEW

DATL:

Septeimber 4, 1980

STATUS: In service.

RESULTS: $\quad$ Not yet determined. 
VERNON ELECTRIC COOPERATIVE

110 North Main Street

Westby, Wisconsin 54667

Earl Jaeger, Manager
REVISED 1980

(608) $634-3121$

SYSTEM: $\quad$ Ripple

SUMMARY: Vernon Electric has been operating a NECO power line carrier system for peak demand reduction for over twenty years. A11 of the utility's thirteen substations are connected to the load management system and about 4,700 water heaters are controlled. When a preset substation load is exceeded, loads are cut back in stages and then restored when the total load is low enough. In addition, the equipment includes a clock feature so that time-of-day load shifting can be used in conjunction with the load totalizing operation. The utility estimates a reduction of over 5,640 kW during control periods, for a savings in. demand charges of about $\$ 400,000$ per year based on $\$ 5.77 / \mathrm{kW}$ from January 1,1980 to May 31,1980 , and $\$ 7.66 / \mathrm{kW}$ from June 6, 1980 to December 31, 1980.

FUNCTION: Control peak substation demand by shedding water heater loads when demand exceeds preset limits.

EQUIPMENT: NECO leveload power line carrier system. Iransmitter, located at each substation, can control any number of receivers via $360-\mathrm{Hz}$ signal.

SAMPLE: $\quad 4,700$ electric water heaters distributed throughout the utility's system.

INCENTIVE: The utility offers a rate reduction for consumers who allow water heater control. 
MONITORING: Substation demand is monitored.

INTERV IEW

DATE:

May 18,1980

STATUS: $\quad$ Program has been in operation for over twenty years. Utility considering adding new equipment.

RESULTS: Vernon estimates annual savings of approximately $\$ 400,000$ due to reduction in demand charges for purchased power. 
VIRGINIA ELECTRIC AND POWER COMPANY

NEW 1980

700 East Franklin Street

Richmond, Virginia 23261

(804) 771-3351

Ed Wickham, Director, Load Management Applications

SYSTEM: $\quad$ Ripple

SUMMARY: In its North Carolina territory, Virginia Electric and Power Company is installing a Sangamo ripple system pursuant to a North Carolina Utilities Commission order requiring water heater contro.1. Virginia Electric and Power Company was required to make available such control, in January 1980, in the city with the greatest electric water heater saturation and to add a new area every six months. Customer voluntary response has been about $11 \%$ so far.

FUNCTION: . To control electric water heaters.

EQUIPMENT: $\quad$ Sangamo $340-\mathrm{Hz}$ system. By the end of 1981 there will be 5 injection stations.

SAMPLE: $\quad$ Estimated 5,000 customers will volunteer by the end of 1981.

INCENTIVE: $\quad \$ 1.85$ per month billing credit.

MONITORING: None.

INTERVIEW

DATE:

August 19, 1980.

STATUS: $\quad 225$ control points installed. Expect 5,000 by the end of 1981. 
REMARKS: $\quad$ Ripple and radio costs were found to be about the same, but only one radio frequency was available and neighboring utilities were already using it. 
WEST MEMPHIS UTILITY DEPARTMENT

REV ISED 1980

604 East Cooper, P.0. Box 38

West Memphis, Arkansas 72301

(501) 735-3355

Joryn Smith, Electrical Superintendent

Gary Rushing, Meter Superintendent

SYSTEM: $\quad$ Ripple

SUMMARY: In an attempt to control peak demands, West Memphis

Utility Department has installed and is utilizing a systemwide ripple control system to cycle central air conditioners. The second year of operation for this program of cycling residential and commercial central air conditioners will be completed in the summer of 1979. Available to all customers, this program now involves 1800 air conditioners. West Memphis Utility Department anticipates the eventual control of 4000 units.

FUNCTION: $\quad$ Cycle off residential and some commercial central air conditioners for 7-1/2 minutes each half-hour as needed to provide load relief.

EQUIPMENT: Sangamo ripple control system, 4 injection points, 1800 dual function receiver switches installed to date.

SAMPLE: $\quad$ Available to all central air conditioning customers. Presently have approximately 1800 receivers installed.

INCENTIVE: $\quad \$ .50 / \mathrm{kW}$ corrected load credit given in June, July, and August.

MONITORING: Nürimal sysleiii münituring. 
INTERV IEW

DATE:

Apri1 28, 1980.

STATUS:

In service.

RESULTS: $\quad$ Presently can shed $2051 \mathrm{~kW}$ load.

REMARKS: West Memphis Utility Department plant to utilize the ripple system to switch street and recreation lighting sys tems. 


\subsection{POWER LINE CARRIER}

\section{Technical Characteristics}

A power line carrier (PLC) system is a C\&LC system that transmits signals via the utility distribution system, operating on essentially the same principle as that of a ripple system. Power line carrier is a relatively new C\&LC system compared to radio and ripple systems.

A unidirectional PLC system performs essentially the same load management functions as those of ripple and radio systems. A bidirectional PLC has the additional capability of confirmation of action, meter reading, remote monitoring, and other distribution automation functions.

A bidirectional power line carrier C\&LC operates in the following manner:

- Utility system data is fed into a computer-based central control unit (CCU). The data, which may originate at external monitoring devices or at the PLC system transponders, are analyzed and compared to previously entered system parameters. Load management of distribution automation functions is initiated when these setpoint parameters are exceeded. The CCU issues preprogrammed commands that are encoded and then sent to the signal injection site via a telemetry link.

- The CCU signals are received at the substation by a substation control unit (SCU), which is capable of receiving or transmitting signals to or from the CCU or the pointof-control transponders. The SCU injects the CCU signals into the distribution network.

- The SCU-injected signal is received at the point of control by a combination transmitter and receiver (transponder) that transmits only when instructed to do so by the $\mathrm{CCU}$, 
via the SCU. Upon receiving an instruction for which it is programmed, the transponder initiates a control (normally switching) or communication function.

PLC systems operate at much higher frequencies than do ripple systems. Typical PLC operating frequencies are in the $5-\mathrm{kHz}$ to $100-\mathrm{kHz}$ range. These higher frequencies offer several advantages. Normal power line noise (due to harmonics and other electrical disturbances) drop off rapidly at frequencies above 3 to $4-\mathrm{kHz}$. This noise reduction allows a PLC system to use less signal power, to achieve an acceptable signal-to-noise ratio for reliable signal transmissinn and reception, llall wuld be needed by a ripple system.

The lower power requirements at higher frequencies also allow better use of solid state technology, which results in a lower injection (transmitting) equipment cost than that of a low-frequency ripple system. The high-frequency operation of a PLC system also allows a more rapid signaling scenario because more information per unit of time can be transmitted as the frequency increases.

The use of higher transmission frequencies also has several disadvantages. Signals attenuate rapidiy at these higher frequencies because power lines are designed for optimum propagation of very low frequency $(6 \mathrm{U}-\mathrm{Hz})$ signals. The higher frequency signals .. also have trouble passing through transformers and capacitors; signal attenuation through a transformer or capacitor is so great that Illost PLC systems are designed to pass the signal through only one transformer (distribution), and require isolation or "trapping" of distribution capacitors during signal transmission to prevent excessive signal loss. This is accomplished by installing an isolator, which presents a relatively high shunt impedance to the communication frequency and a low shunt impedance to the power frequency, thereby preventing the communication signal from passing through the capacitor and being attenuated. The addition of repeaters or amplifiers is sometimes necessary to compensate for line- or 
transformer-induced signal losses; this is particularly true for the return signal in bidirectional communication.

These additional equipment requirements tend to offset the lower costs of the transmitting equipment, especially when a PLC system is employed as a unidirectional system. In a bidirectional system, the economic advantages of lower transmitter costs (as compared to ripple systems) are more important because every point of control uses a transmitter. The extra signal repeaters, amplifiers, and capacitor/ transformer coupling hardware used in a unidirectional PLC system will also function in a bidirectional PLC system at no additional cost.

\section{System Costs}

The development of valid "typical" per point costs for power line carrier systems poses several problems. Utility experience with PLC has, with only one exception; been limited to small demonstration projects, most of which are using first- or second-generation hardware. As such, utility experience with actual incurred costs for large-scale systems is extremely limited.

Another problem is that the manufacturers of PLC hardware have been reluctant to supply detailed costing information. Two manufacturers did supply near-term (2-5 years) projections on the per-point hardware costs that a utility could expect to pay for a 50,000 - to $100,000-$ poinl PLC system.

Manufacturer A - 3-year projection

$\$ 337$ per point for complete bidirectional system

$\$ 87$ per point for complete unidirectional system

Manufacturer B - 5-year projection

$\$ 200$ per point for complete bidirectional system

$\$ 60$ per point for complete unidirectional system 
The differences in the two manufacturers' cost projections are primarily due to the different time frames ( 3 and 5 years) over which the projections are made.

The receiver switches and transponders used in PLC systems rely heavily on the use of large-scale integrated circuitry (LSI). Accordingly, prices for the remote units are highly sensitive to the volume that can be manufactured. Since the present market for PLC hardware is just beginning to develop, manufacturing volumes are low and prices are high.

It is assumed that the manufacturers' cust projections do not include installation. Adding an assumed $\$ 20$ per point installation cost to the projected costs would result in a projected $\$ 80$ to $\$ 107$ per point installed cost for a unidirectional power line rarrier system. 
Power Line Carrier Equipment Manufacturers

American Science and Engineering, Inc. 955 Massachusetts Avenue

Cambridge, Massachusetts 02139

Compuguard Corporation

4709 Baum Boulevard

Pittsburgh, Pennsylvania 15213

General Electric Company

Meter and Instrument Business Department

Somersworth, NH 03878

Rockwell International

Municipal and Utility Divison

Pittsburgh, Pennsyivania 15208

Westinghouse Electric Corporation

Meter Division

Raleigh, North Carolina 27611 
$2-104$

\section{THIS PAGE \\ WAS INTENTIONALLY \\ LEFT BLANK}


Table 2-8

Power Line Carrier Projects Sumary

\begin{tabular}{|c|c|}
\hline Utility & Contact \\
\hline Anerican Electric Power & $\begin{array}{l}\text { Dorman M. Mill ler, Vice President, Customer } \\
\text { Service } \\
\text { (614) } 223-1370\end{array}$ \\
\hline Boston Edison Company & $\begin{array}{l}\text { Eric M. Maytch, Project Engineer } \\
\text { (6677) } 424-3518 \text { Bro }\end{array}$ \\
\hline $\begin{array}{l}\text { Carolina Power and Light } \\
\text { Company }\end{array}$ & $\begin{array}{l}\text { G.E. Shuford, Jr., Project Engineer } \\
\text { (919) }\end{array}$ \\
\hline Commonweal th Edison & $\underset{\text { John Eilering, vice President }}{(312) \text { 294-3333 }}$ \\
\hline $\begin{array}{l}\text { Delmarva Power and } \\
\text { Light Company }\end{array}$ & $\begin{array}{l}\text { Edward G.G. Fleck, Assi istant Super intendent } \\
{[302)_{429-3367}}\end{array}$ \\
\hline Duke Power Company & $\begin{array}{l}\text { G.E. Stubbins, Manager, Load Analysis } \\
\text { (704) } 373-4372\end{array}$ \\
\hline Florida Power Corporation & $\begin{array}{l}\text { Mallace L, Barron, Jr., Manager, Luad } \\
\text { Forecasting and Research } \\
\text { (813) } 866-5440\end{array}$ \\
\hline $\begin{array}{l}\text { Independence Power and } \\
\text { Light Depar tment }\end{array}$ & $\begin{array}{l}\text { Ed Halentine, Manager, Economic Planning } \\
\text { and Rates } \\
\text { (816) } 796-4400\end{array}$ \\
\hline Northern States Power & $\begin{array}{l}\text { Conrad Aas, Administrator, Research } \\
\text { Prograns } \\
\text { (612) 330-5766 }\end{array}$ \\
\hline $\begin{array}{l}\text { Northeast Utilitities } \\
\text { Service Conpany }\end{array}$ & 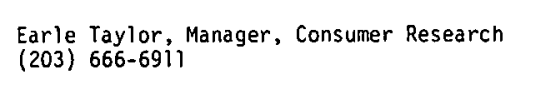 \\
\hline Pacific Gas and Electric & $\begin{array}{l}\text { John S. Cooper, Manager, Energy Conservation } \\
\text { and Services, } \\
(415) \text { 781-4211 }\end{array}$ \\
\hline $\begin{array}{l}\text { Philadel phia Electric } \\
\text { Company }\end{array}$ & $\begin{array}{l}\text { John H. Blose, Senior Engineer, Energy } \\
\text { Oitstribution Research } \\
\text { (215) } 841-4866\end{array}$ \\
\hline $\begin{array}{l}\text { St. Joseph Light and } \\
\text { Power Liompany }\end{array}$ & $\begin{array}{l}\text { John W. Spencer, Load Research Coordtnator } \\
\text { (816) } 233-8888\end{array}$ \\
\hline $\begin{array}{l}\text { San Diego Gas and Electric } \\
\text { Company }\end{array}$ & $\begin{array}{l}\text { Thumas o. Stickles, Project Manager } \\
(714) 232-4252\end{array}$ \\
\hline Suizpping Shoals EMC & $\begin{array}{l}\text { Mickey Autry, Engincering Aide } \\
\text { (404) } 786-3484\end{array}$ \\
\hline Springfield city utilities & $\begin{array}{l}\text { Melvin Black, Supervisor, Customer Service } \\
\text { Fielol operations } \\
\text { (417) } 865-8311\end{array}$ \\
\hline
\end{tabular}

\begin{tabular}{|c|c|c|c|c|c|}
\hline$\frac{\text { Equiprent }}{\text { ATC }}$ & $\begin{array}{c}\begin{array}{c}\text { Control } \\
\text { Function(s) }\end{array} \\
\text { RMR-SLCC }\end{array}$ & $\frac{\frac{\substack{\text { Number } \\
\text { of Points }}}{30}}{30}$ & $\begin{array}{c}\underline{\text { class }} \\
\text { Demonstration }\end{array}$ & $\begin{array}{l}\frac{\text { Status }}{\text { In service }} \\
\end{array}$ & $\$ 10 /$ month \\
\hline W-GE & RMR-DA-LC & 18 & $\begin{array}{l}\text { Comparative } \\
\text { demonstration }\end{array}$ & Completed & None \\
\hline c & RMR-DA-SLC & 700 & Demonstration & On order & None \\
\hline GE & RMR-LC & 250 & Demonstration & In service & $\begin{array}{l}158 \text { rate reduction - four } \\
\text { summer months. }\end{array}$ \\
\hline GE & RMR & 100 & Demonstration & In service & None \\
\hline GE-ASBE & RMR-DA-LC-LR & 5,945 & Demonstration & $\begin{array}{l}\text { Partiallyy } \\
\text { in service }\end{array}$ & Load control or TOD rate \\
\hline ASBE & RMR-LC & 185 & Demonstration & In service & $\begin{array}{l}\$ 12 / \text { month for } \text { wHF } \\
\$ 3 / \text { month for } \mathrm{AC}\end{array}$ \\
\hline AS\&E & LR & 400 & Demonstration & $\begin{array}{l}\text { Partially } \\
\text { in service }\end{array}$ & None \\
\hline W-ASSE & RMREDA & 310 & $\begin{array}{l}\text { Comparative } \\
\text { demonstration }\end{array}$ & In service & None \\
\hline w & RMR-DA-LC & 100 & Demuris Lration & In service & None \\
\hline $\mathrm{R}$ & RMR-LC & 2,000 & Demonstration & $\begin{array}{l}\text { Partially } \\
\text { in service }\end{array}$ & $\$ 2 /$ month \\
\hline GE & RMR & 50 & Demonstration & Completed & None \\
\hline ASBE & RMR-LC & 210 & Load Research & In service & None \\
\hline AS\&E & RMR-DA-LC & 760 & nemonstration & $\begin{array}{l}\text { Partiallyy } \\
\text { in service }\end{array}$ & $\$ 2 /$ ton/month \\
\hline R & RMB-SII. & 125 & Demonstration & $\begin{array}{l}\text { Partially } \\
\text { in service }\end{array}$ & None \\
\hline ASBE & RMR & 232 & Load research & $\begin{array}{l}\text { Partiallhy } \\
\text { in service }\end{array}$ & None \\
\hline
\end{tabular}

\begin{tabular}{|c|c|}
\hline Results/Remarks & Contact Date \\
\hline $\mathrm{N} / \mathrm{A}$ & April 24, 1980 \\
\hline Rel iabili ity needs to be improved. & May 7, 1980 \\
\hline N/A & September 22, 1977 \\
\hline N/A & August 15,1980 \\
\hline N/A & August 22, 1978 \\
\hline N/A & April 30, 1980 \\
\hline N/A & September 9, 1980 \\
\hline N/A & November 13, 1980 \\
\hline May add load control functions. & August 14,1980 \\
\hline Marginal success - not reliable. & August 13, 1980 \\
\hline N/A & September 17,1980 \\
\hline Contemplating expanded test. & May 5, 1980 \\
\hline N/A & Apri1 21, 1980 \\
\hline Results ava ilable July 11, 1980. & May 7, 1980 \\
\hline N/A & November 13, 1980 \\
\hline N/A & June 20, 1979 \\
\hline
\end{tabular}


THIS PAGE

WAS INTENTIONALLY

LEFT BLANK 
Table 2-8 (Continued)

\begin{tabular}{|c|c|c|c|c|c|c|c|c|c|}
\hline Utility & $\underline{\text { Contact }}$ & Equiprent & $\begin{array}{l}\text { Control } \\
\text { function(s) }\end{array}$ & $\begin{array}{l}\text { Number } \\
\text { of Points }\end{array}$ & class & $\underline{\text { status }}$ & Incentive & Resul L5/Remarks & Contact Date \\
\hline Tennessee val ley Authority & $\begin{array}{l}\text { Patricicia Harris, Load Management Branch } \\
\text { (615) 755-3591. }\end{array}$ & Undetermined & RMR-DA-LC & 5,000 & Demonstration & Planning & N/A & $\begin{array}{l}\text { Joint DOE/ORNL/TVA/TVPPA/Athens } \\
\text { Utilitities Board }\end{array}$ & April 28, 1980 \\
\hline $\begin{array}{l}\text { The United Il luminat ing } \\
\text { Company }\end{array}$ & $\begin{array}{l}\text { Elva Richardson, Associate Planning } \\
\text { Ennineer } \\
(203) \text { - } 787-\text { - } 7952\end{array}$ & R & RMR & 300 & Denonstration & $\begin{array}{l}\text { Partially' } \\
\text { in service }\end{array}$ & None & $\begin{array}{l}\text { All points are commercial class } \\
\text { custoners. Whil to a adding } 2000 \\
\text { residential customers. }\end{array}$ & September 15, 1980 \\
\hline $\begin{array}{l}\text { Verendrye Electric Coop, } \\
\text { Inc. }\end{array}$ & 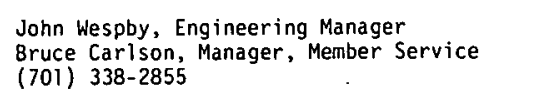 & ASSE & RMR-DA-LC & 200 & Demonstration & $\begin{array}{l}\text { Partialiy } \\
\text { in service }\end{array}$ & $\begin{array}{l}\text { 1.1 to } 1.5 \mathrm{ft} / \text { / wh saving } \\
\text { for controlled space heating; } \\
\text { S1/KW/month - WH. }\end{array}$ & N/A & Novenber 13,1980 \\
\hline $\begin{array}{l}\text { Virginia Electric and } \\
\text { Power Company }\end{array}$ & 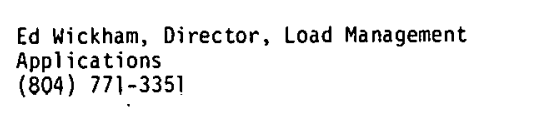 & $G \varepsilon$ & RMR-LC & 20 & Denonstration & In service & \$1. $85 /$ month - water heater & $\begin{array}{l}\text { Instal led on } 34.5 \mathrm{kV} \text {. Some } \\
\text { noise problems. }\end{array}$ & July 14, 1980 \\
\hline $\begin{array}{l}\text { Wisconsin Electric } \\
\text { Power Company }\end{array}$ & $\begin{array}{l}\text { Glenn Lokken, Super intendent, Special } \\
\text { Studdies } \\
\text { (414) 277-2345 }\end{array}$ & ASSE & RMR-DA-LC & 150,000 & Systennide & $\begin{array}{l}\text { Partially } \\
\text { in service }\end{array}$ & $\$ 4 /$ month - water heater & $16,000 \mathrm{WH}$ now under control & July 9,1980 \\
\hline $\begin{array}{l}\text { Wisconsin Public Service } \\
\text { Corporation }\end{array}$ & $\begin{array}{l}\text { William A. Swan, Load Management Engineer } \\
(414) \text { \33-1615 }\end{array}$ & R & RMR-SLC & 450 & Load research & In service & s2/month & Report due November 1980. & July 16, 1980 \\
\hline
\end{tabular}

Legend

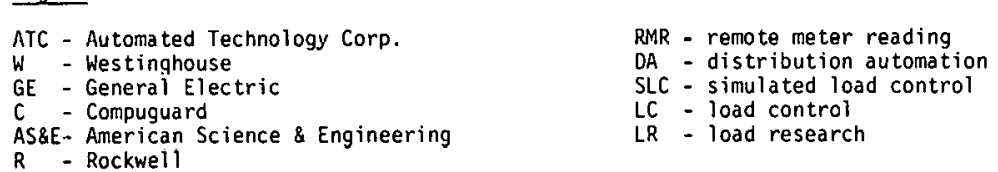


PACIFIC GAS AND ELECTRIC COMPANY

REVISED 1980

77 Beale Street

San Francisco, California 94106

(415) $781-4211$

R. M. Mertz, Manager, Energy Conservation and Service

SYSTEM: $\quad$ Power Line Carrier

SUMMARY: This program involves a 75-customer automatic meter reading and air conditioner cycling experiment on two dictrihution feeders in walnut creek. The test is configurcd to obtain over $99 \%$ valid meter reading and control on first request. A meter-reading-only test in 1976 evaluated the communications range of this system. Remote meter reading and air conditioning control was evaluated on the 75 customers in 1977 , 1978, and 1979.

FUNCTION: $\quad$ Remote meter reading and cycling of customer air conditioners.

EQUIPMENT: General Electric AMRAC.

SAMPLE: $\quad 75$ residential customers.

INCENTIVE: $\quad \$ 6$ per month, May through September on an experimental rate.

MONITORING: Comparative meter readings.

INTERVIEW

DATE: $\quad$ September 16, 1980

STATUS: $\quad$ Equipment has been removed and customers' air conditioners have been returned to their original condition. 
RESULTS: The AMRAC system performed well for circuit distances from one to fourteen miles between the section control unit and the meter terminal unit. Harmonics from the $38-\mathrm{kHz}$ carrier, however, caused an appreciable amount of radio interference. It is anticipated that if all homes were to be equipped with meter terminal units, and operating with the amount of signaling required for time-of-use metering, the interference could be intolerable.

A significant drop in the percentage of valid meter readings was also observed when the length of the primary circuit between section control unit and meter terminal unit exceeded 6,500 feet. 
PACIFIC GAS AND ELECTRIC COMPANY

REV ISED 1980

77 Beale Street

San Francisco, California 94106

(415) $781-4211$

R.M. Mertz, Manager, Energy Conservation and Services

SYSTEM: $\quad$ Power Line Carrier

SUMMARY: A 2,000-point hardware demonstration trial of the Rockwell Power Line Carrier System will begin this summer. Half of the points will be transponders capable of remote meter readings, time-nf-day metering, and load control.

The other half will be receivers with one-way communication only. The Rockwell system is similar to the General Electric AMRAC system; the difference lies in Rockwe $17^{\prime} \mathrm{s}$ one-way communication option and frequency of the signal sent over the power lines.

EQUIPMENT: $\quad$ Rockwell Power Line Carrier. Central controller, substation control unit and customer site transponder.

INCENTIVE: $\quad \$ 2$ per month.

INTERV IEW

DATE:

September 17, 1980.

STATUS: $\quad$ Two-way units are expected to arrive in September 1980; one-way units will arrive in January 1981.

RESULTS: $\quad$ Not yet available. 
SAN DIEGO GAS AND ELECTRIC COMPANY

REVISED 1980

P.0. Box 1831

San Diego, California 92112

(714) 232-4252

Thomas D. Stickels, Project Manager, Load Management

SYSTEM: $\quad$ Power Line Carrier

SUMMARY: $\quad$ Starting JuTy 1, 1979, a 12-month test of a two-way power line carrier system, financed by DOE, is being conducted to determine the capability and limitations of the equipment; to measure the value of water heating, air conditioning, and central electric heating load deferral; and to experiment with remote time-of-use metering and distribution automation.

FUNCTION: $\quad$ Read meters remotely; switch time-of-use meters; and cycle water heaters, air conditioners, and electric space heaters. Cycled off-time periods will be: air conditioner7 minutes, 13 minutes; water heaters - 15 minutes, one hour (primary) and 2, 3, 4, and 6 hours (secondary); and space heaters (preliminary) - 7 minutes, 13 minutes.

EQUIPMENT: American Science and Engineering, Inc. ASEP System for distribution automation.

SAMPLE: $\quad 640$ single-family customers

50 multi-family customers

50 commercial/industrial

10 distribution automation

750 total points on two substations

\footnotetext{
640 single-family:

200 on time-of-use rates only
} 
140 on time-of-use rates and load deferment

150 on load deferment only

150 statistical control groups

50 multi-family:

25 on load deferment

25 on time-of-use rates

50 commercial/industrial:

25 on load deferment

25 on time-of-use rates

INCENTIVE: Load Deferment Study - Each month, an amount will be deducted from each participant's bill according to the following table:

$$
\begin{array}{lll}
\text { Air Conditioner } & \$ 2.00 / \text { ton } / \text { month } & \text { May } / \text { September } \\
\text { Water Healer } & \$ 0.65 / \mathrm{kW} / \text { month } & \text { A11 months } \\
\text { Space Heater } & \$ 0.90 / \mathrm{kW} / \text { month } & \text { November } / \text { April }
\end{array}
$$

Also, no San Diego Gas and Electric rate increases will apply to participants during this study. Statistical Control Group - Each participant will be given an aqua massage showerhead. No San Diego Gas and Electric rate increases will apply to the group of participants during this study.

Time-of-Use Rate Study - Minimum quarterly rebate is $\$ 6.00$ per participant. Opportunity to save money by using less "on-peak" energy. Time-of-use rates will not be adjusted upward as a result of a San Diego Gas and Electric rate increase.

INTERV IEW DATE:

May 7, 1980.

RESULTS: $\quad$ Customer volunteer response excellent. DOE will not be releasing final report before october 1980. 
TENNESSEE VALLEY AUTHORITY

REVISED 1980

210 Power Building

Chattanooga, Tennessee 37401

(615) $755-3591$

Patricia H. Harris, Load Management Branch

SYSTEM: $\quad$ Power Line Carrier

SUMMARY: Tennessee Valley Authority, the Department of Energy, Oak Ridge National Laboratory, the Tennessee Valley Public Power Association, and Athens Utilities Board are participating in a $\$ 9 \mathrm{million}$ cooperative project to demonstrate load management techniques utilizing a two-way communications system.

Under this DOE-funded project, Athens Utilities Board, a Tennessee Valley Authority power distributor, has been selected for automation of its system. Approximately 5,000 homes will be retrofitted with load management devices on such appliances as water heaters, heat pumps, and resistance heaters. This project will use a two-way communications system (as yet undetermined) to control energy storage devices, and to effect automatic meter reading and automatic load switching in substations. This two-year test will be conducted at the local electric system at Athens, Tennessee. Certain technologies will be tested using central control of the distribution system. Dispersed energy storage using advanced communication and controt systems are also slated to be incorporated into the project.

FUNCTION: $\quad$ Control energy storage devices; perform automatic meter readings, distribution automation, and load switching. 
EQUIPMENT: $\quad$ Not yet determined.

SAMPLE: $\quad 5,000$ homes.

INCENTIVE: Undetermined.

INTERVIEW

DATE:

JuTy 25, 1980.

STATUS: Department of Energy/0ak Ridge National Laboratory/ Tennessee Valley Authority/Tennessce Vallcy Public Power Association contract was signed in July 1980.

RESULTS: $\quad$ Not yet determined.

REMARKS: While this project is a joint Department of Energy/ Tennessee Valley Authority/Tennessee Valley Public Power Association effort, it is almost completely under the auspices of the Department of Energy and Oak Ridge National Laboratory. Expenditures of up to $\$ 9$ million may be required, including $\$ 8.5$ million from the Department of Energy, $\$ 400,000$ from the Tennessee Valley Authority and $\$ 100,000$ from the power distributor. 
VIRGINIA ELECTRIC AND POWER COMPANY

NEW 1980

700 East Franklin Street

Richmond, Virginia 23261

(804) $771-3351$

Ed Wickham, Director, Load Management Applications

SYSTEM: $\quad$ Power Line Carrier

SUMMARY: Virginia Electric and Power Company is working with General

Electric on the application of the AMRAC bidirectional system that may be installed in a pilot project at three substations, one with a circuit serving large industrial customers, one with a 47-mile long, 34.5-kV circuit, and one with an underground residential circuit. Preliminary studies found AMRAC to be unreliable because of noise on high-voltage circuits. Design changes are underway.

FUNCTION: To control loads, read meters, and perform other distribution automation functions.

EQUIPMENT: General Electric AMRAC system.

INCENTIVE: Residential water heater customer- $\$ 1.85$ per month. Large commercial and industrial customers - TOD rates.

MONITORING: Not yet available.

INTERV IEW

DATE:

November 25, 1980.

STATUS: Planning.

RESULTS: $\quad$ Not yet determined. 
WISCONSIN ELECTRIC POWER COMPANY

P. 0. Box 2046

Milwaukee, Wisconsin 53201

REVISED 1980

(414) $277-2345$

Richard A. Abdoo, Director, Corporate Planning

Glen Lokken, Superintendent, Special Studies

SYSTEM: $\quad$ Power Line Carrier

SUMMARY: Wisconsin Electric Power, having successfully concluded a one year test using American Science and Engineering power line carrier equipment for water heater switching and remote meter reading at 500 residences, has in effect a rate schedule available on a voluntary basis to all 150,000 electric water heater customers. Wisconsin Electric Power expects $75 \%$ of the eligible customers to adopt one of numerous incentive or reduced rates. In the 1976-77 test, water heaters were cycled off for up to four hours with minimal complaints.

FUNCTION: Control of water heaters, remote meter reading, load research, and other distribution automation functions.

EQUIPMENT: American Science and Engineering, Inc. ASEP System.

SAMPLE: $\quad$ Original project involved 500 residential customers on two substations in areas of high electric water heater saturation. Present phase will involve controlling 150,000 water heaters.

INCENTIVE: During the test period, customers received $\$ 2.00$ per month, paid semi-annually. Filed rate provides a $\$ 1.50$ per month allowance on the residential rate. A change to $\$ 4.00$ per month is pending. 
MONITORING: Transponder on each home plus strip charts at the substations.

INTERV IEW

DATE:

Ju1y $9,1980$.

STATUS:

In service since July, 1976. Presently expanding.

RESULTS: Final research report completed. Wisconsin Electric Power has installed segments of a two-way system that will ultimately control 150,000 water heaters, perform automatic remote meter reading on 500 general service customers, and control distribution capacitor banks and load tap changing transformers. 16,000 electric water heaters are now controlled. 
WISCONSIN PUBLIC SERVICE CORPORATION

REVISED 1980

P.0. Box 700

Green Bay, Wiscons in 54305

(414) 433-1615

William A. Swan, Load Management Engineer.

SYSTEM: $\quad$ Power Line Carrier

SUMMARY: Isolated water heater circuits at 500 residential customer locations will be remotely metered in this demonstration project. In addition to the remote metering, an aroundthe-clock load survey w111 be conducted. The data gathered will be categorized by water heater size and capacity (eight categories) in order to develop load curves and demand and payback curves. These will be used to predict water heating load demand for the entire utility system. The utility is considering expansion of the twoyear project to include load control and time-of-use metering if the preliminary study goes well.

FUNCTION: $\quad$ Provide remote metering and load survey information for use in projecting water heating load demands.

EQUIPMENT: Rockwell International bidirectional power line carrier. Central controller located in Green Bay with 500 remote installations.

SAMPLE: IEolated water heater circuite in 400 residential installations in Antigo, Wisconsin and 100 residential installations in DePere, Wisconsin.

INCENTIVE: Voluntary participants are paid $\$ 2.00$ per month.

MONITORING: Automatic continuous recording of water heater load. 
INTERV IEW

DATE:

STATUS:

RESULTS:
April 30, 1980

In service.

Preliminary evaluation completed. 


$$
2-120
$$

\title{
THIS PAGE
}

WAS INTENTIONALLY

\author{
LEFT BLANK
}




\subsection{COMBINATION RADIO AND POWER LINE CARRIER}

\section{Technical Characteristics}

A combination radio and power line carrier system is a hybrid application of two existing technologies, utilizing the same major components as those of a radio control system along with several elements of a power line carrier system. Functionally, this type of system closely resembles a radio control system in the sense that load management signals originate at a control center and are then transmitted, via an FM radio transmitter, to radio receivers located throughout the service territory.

In a radio control system, these receivers are all located at the customer's location or point of control. In this hybrid system, the radio receivers are located on distribution transformer poles. This polemounted receiver is connected to a small power line carrier transmitter, the output of which is coupled to the secondary of the distribution transformer. The pole-mounted receiver, upon receiving the proper load management command(s) from central control, activates the power line carrier transmitter which relays the control commands over the secondary power lines to the customer locations via a $215-\mathrm{kHz}$ frequency modulated carrier signal. These commands are received and decoded by power line carrier receiver switches at the customer location. This application allows all of the customers on a single distribution transformer to be served by a single radio receiver. This system can also operate as a total radio control system with the radio receiver switch located at the customer's home. The type of recelver (carrier vs. radio) that would be used in any one particular point of control in this type of system would depend upon the resultant per-point cost.

The point-of-control device in this type of system is essentially the same as that found in a unidirectional system power line carrier with a possible mix of radio receiver switches, and the primary method of control telemetry is the same as that found in a unidirectional radio control system.

Another unique aspect of this system is the manner in which load manage- 
ment commands are coded. In a conventional radio system, tonal signals are broadcasted, instructing the receiver switches to either make or break a circuit. In a traditional radio system there are ten or twenty distinct tonal commands. Each receiver switch is programmed to respond to one of these tonal commands, which, in effect, gives the utility ten to twenty levels of control capability. The combination system presently available utilizes an eight-bit, digitally encoded command system which greatly increases the address capability, as well as the functional flexibility of the system. This coding system enables the utility to separately address up to 32 different receiver groups with up to seven different command functions in each group.

\section{System Costs}

The average costs for the various components of a combination radio and power line carrier system, according to its manufacturer, are as follows:

- Standard central control unit, including message generation, capable of time or manual control costs $\$ 15,000$. This device may or may not interface with other hardware, depending upon the level of redundancy and suphistication desired.

- Pole-mounted radio receiver with carrier transmitter ( $R C X$ unit) costs $\$ 155$.

- Single-function power line carrier reçejver switch cost.s $\$ 50$.

- Single-function radio receiver switch costs $\$ 100$; dual-function radio receiver switch costs $\$ 125$.

Since the primary method of signal transmission for this hybrid system is identical to that of a standard radio control system, the associated installed costs of this transmitt.ing equipment for a hybrid system would be comparable to those costs found in a standard radio system. The installed costs of the central control and other related hardware for a hybrid system could also be expected to closely compare to those of a standared radio system, since the only real difference between a central control for hybrid and standard radio system, assuming systems of equal size and scope, would be the additional logic and hardware needed for digitally encoded 
addressing and commands. Although this incremental equipment cost difference could amount to several thousand dollars and may be expressed quantitatively as the incremental difference between the $\$ 15,000$ cost of the hybrid system message generation unit and the comparable equipment for a radio system, the cost difference would become relatively insignificant when apportioned out over a reasonably sized system.

Based on the above assumptions, the total apportioned per point costs of central control, transmission, and related equipment for a hybrid system will be considered in this analysis to be the same as those that would be experienced in a radio system of the same size and scope.

As demonstrated in previous analyses, the three major cost components of a remote C\&LC system are: the equipment cost of the receiver switch, the installation cost for the receiver switch, and the apportioned per point cost of transmission and control. The apportioned per point cost has been shown to be a direct function of receiver saturation in a C\&LC system. Since the per point apportioned cost drops as receiver saturation increases, this cost can vary greatiy, depending upon where the system falls on the declining cost curve.

In a 11 C\&LC systems examined thus far, the installed receiver switch cost was a function of the average, cost of the receiver switch and the average receiver switch installation cost. In a hybrid system, the average installed receiver cost is also a function of the above cost elements, but these costs can vary widely, depending upon the form the system takes.

As described earlier, a hybrid system utilizes a single radio receiver to serve several points of control. This is accomplished by coupling the receiver with a carrier transmitter and utilizing carrier receiver switches at the point of control. Since the carrier receiver switches are cheaper than the radio receiver switches, the hybrid application can be cheaper than straight radio as long as a sufficientiy high number of carrier receiver switches are served by each pole-mounted receive-transmit unit. This is due to the fact that the installed cost of the pole-mounted equipment figures into the total costs of the receiver switches on an apportioned basis. For example, if a utility buys a pole-mounted receiver/ 
transmitter (RCX) for $\$ 155$ and it costs $\$ 30$ to install this unit, then the installed cost of the RCX is $\$ 185$. This RCX serves one or more carrier receiver switches. If the utility pays $\$ 50$ for this receiver switch and $\$ 20$ to install it, then its installed cost is $\$ 70$. If the RCX only serves one receiver switch, then the total installed cost of the receiver switch is $\$ 185$ plus $\$ 70$ or $\$ 255$. If the $R C X$ serves more than one unit, then its installed cost is apportioned out among the number of receiver switches it serves. As such, it can be expected that as the number of receiver switches per RCX increases, the per point installed cost of the receiver switches decreases.

As mentioned earlier, this hybrid system may also use radio receiver switches directly at the point of control. This type of receiver switch would be used where the number of controllable points along the secondary of any given distribution transformer is too low to make the use of an RCX cost effective. The quoted cost of this radio receiver switch is $\$ 100$ (single-function mode1). With an assumed installation cost of $\$ 20$, its installed cost would be $\$ 120$. Thus, it would be expected that a radio receiver switch would be used wherever the installed costs of carrier receiver switches, including RCX apportioned costs, exceed $\$ 120$. Based on the costs developed thus far, the number of carrier receiver switches per RCX required to make the hybrid application more cost effective than radio would be 3.7. Since the number of homes serviced by common secondaries can vary greatly, depending upon population densities and distribution system characteristics, the resultant average receiver switch costs in a hybrid system becomes even more utility-specific than in other C\&LC systems.

Defining the "typical" total per point costs of a hybrid system depends, then, on first defining a "typical" utility system. For the purposes of this analysis, the following cost assumptions will be made:

- The installed cost of an RCX unit (pole-mounted radio receivercarrier transmitter) will be $\$ 185$.

- The installed cost of a carrier receiver switch will be $\$ 70$.

- The installed cost of a radio receiver switch will be $\$ 120$. 
- The apportioned per point cost, due to the installed costs of central control, transmission, and related hardware, will be $\$ 20$ at the "typical" total receiver saturation level. This assumption is based on defining the "typical" saturation level as that point where the apportioned costs equal the average switch installation costs.

Based on the above assumptions, the average total per point cost of any hybrid system may be determined quantitatively as follows:

Total per point cost $=R(\$ 120)+(100-R) \frac{\$ 70(C)+\$ 185}{C}+\$ 20$

$$
\begin{aligned}
\text { Where } R= & \text { the percentage of straight radio switches found within } \\
& \text { the system } \\
\text { and, } C= & \begin{array}{l}
\text { the average number of carrier receivers per } R C X \text { found } \\
\text { within the system. }
\end{array}
\end{aligned}
$$

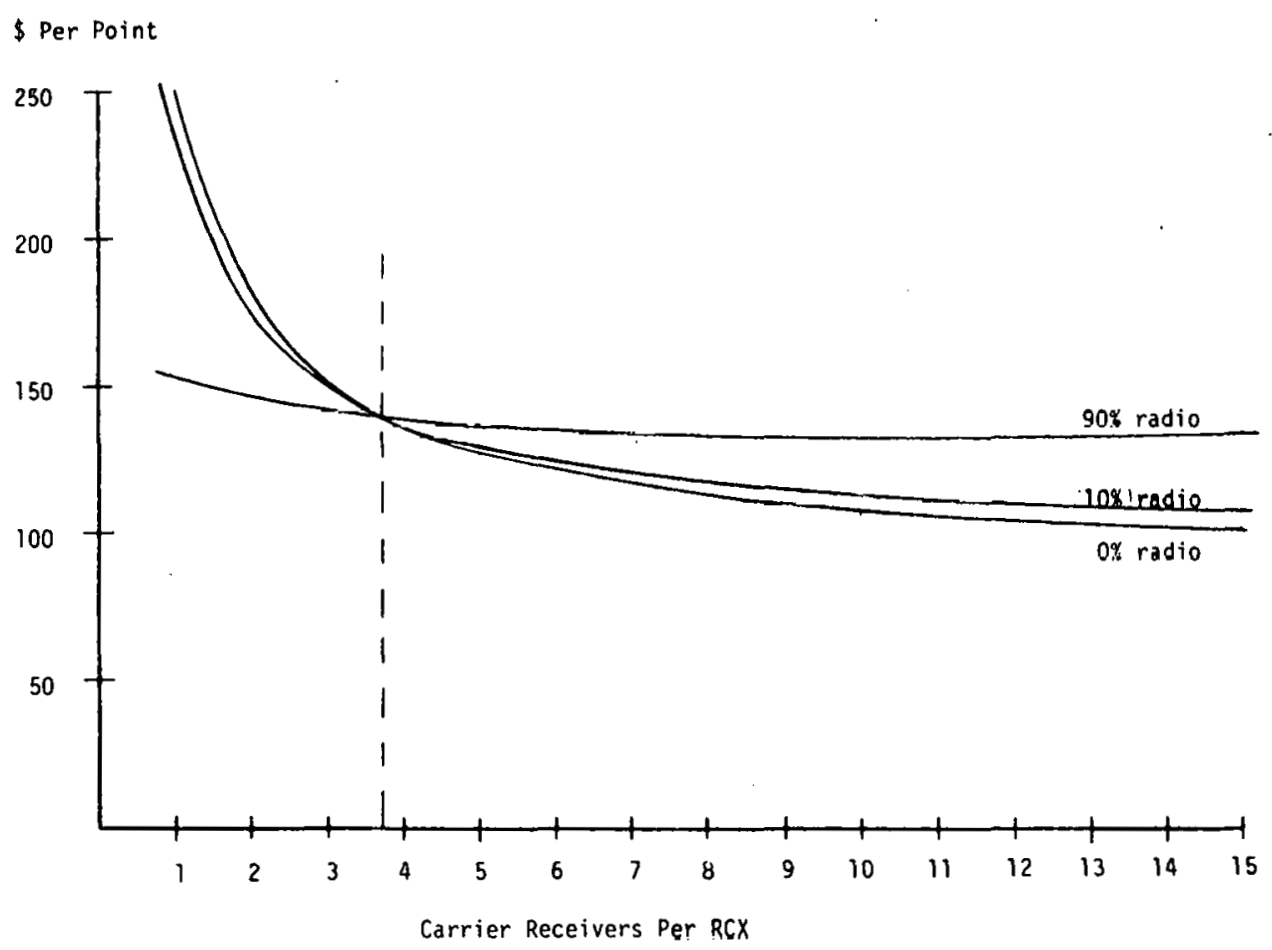

Table 2-9. Total Per Point Cost as a Function of Carrier Receivers Per RCX 
Table 2-9 illustrates a family of curves, based on the above expression, in terms of both average number of carrier receivers per RCX and straight radio receiver mix. Each curve assumes a fixed percentage of straight radio switches $(0 \%, 10 \%, 90 \%)$ and follows the carrier receiver per $\mathrm{RCX}$ relationship. All of the curves assume a total receiver switch saturation at the previously described "typical" level. As Table 2-9 shows, at carrier receiver per RCX levels below 3.7, it is cheaper to utilize a high percentage of straight radio switches. At levels above 3.7, it is cheaper to use carrier receivers. It can be assumed that the "typical" hybrid system would average at 1east. 3.7 receivers per RCX, Otherwise, it would make little sense to utilizc a hybrid system. The manufar.urer of this equipment has estimated that a "typical" system would result in an average of six to eight receivers per RCX. Applying the more conservative average of six carrier receivers per RCX would result in a total per point cost of between $\$ 121$ for a totally hybrid system and $\$ 140$ for a straight rad10 system. Identifying where the per point cost of a "typical" system will fall within this range will depend on the mix of straight radio receivers. If the total mix of straight radio receivers is assumed to be $10 \%$ in the "typical" system, then the "typical" per point cost of this hybrid system would be $\$ 123$. 
Combination Radio and Power Line Carrier Equipment Manufacturer

Scientific Atlanta

Load Management Division

4300 N.E. Expressway

Atlanta, Georgia 30340 


$$
2-128
$$

THIS PAGE

WAS INTENTIONALLY

LEFT BLANK 
Table 2-10

Combination Radio and Power Line Carrier Projects Sunmary

\begin{tabular}{|c|c|c|c|c|c|c|c|c|c|}
\hline $\begin{array}{l}\underline{\underline{U t i l i t y}} \\
\text { Hater, Gas, and Light } \\
\text { Comnis ission of Albany, Georgia }\end{array}$ & $\begin{array}{l}\text { Contact } \\
\text { Don Baldwin, Director } \\
(9919) 883-8330\end{array}$ & $\frac{\frac{\text { Equipment }}{S A}}{\text { SA }}$ & 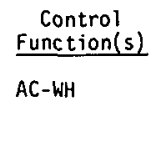 & $\frac{\begin{array}{c}\text { Number } \\
\text { of Points }\end{array}}{4,450}$ & $\frac{\underline{\text { llass }}}{\text { Systemmide }}$ & $\begin{array}{l}\text { Status } \\
\text { In service }\end{array}$ & $\begin{array}{l}\text { Incentive } \\
\text { None }\end{array}$ & $\begin{array}{l}\text { Result ts/Renarks } \\
\text { Estimated savings of } \$ 569,000 \\
\text { summer off } 1978 .\end{array}$ & $\begin{array}{l}\text { Contact Date } \\
\text { June } 19,1979\end{array}$ \\
\hline American Electric Power & $\begin{array}{l}\text { Dorman M. Miller, Vice President, } \\
\text { customer Services } \\
(614) 223-1370\end{array}$ & SA & $\mathrm{AC}-\mathrm{SH}$ & 120 & Demonstration & In service & $\begin{array}{l}\$ 10 / \text { month - Oc tober thru Apri1 } \\
\$ 5 / \text { month - May thru September }\end{array}$ & N/A & April 24, 1980 \\
\hline $\begin{array}{l}\text { Appalachian Electric } \\
\text { cooperative }\end{array}$ & $\begin{array}{l}\text { Charles Balch, General Manager } \\
(615) 475-2032\end{array}$ & SA & AC-WH-SH & 200 & Demonstration & $\begin{array}{l}\text { Partiallyy } \\
\text { in service }\end{array}$ & None & $\begin{array}{l}\text { Expect } 1000 \text { points by December } \\
\text { 1980. }\end{array}$ & August 25, 1980 \\
\hline $\begin{array}{l}\text { Ayden Water and Light } \\
\text { Department }\end{array}$ & $\begin{array}{l}\text { Michael Finney, Director of Utilities } \\
(919) 745-4152\end{array}$ & SA & WH-AC-APP & 300 & Systenvivide & $\begin{array}{l}\text { Partially } \\
\text { in service }\end{array}$ & $\begin{array}{l}\$ 1.25 / \text { month }- \text { WH. } \$ 1.50 / \text { month - } \\
\text { AC and } \mathrm{HP} 12 \text { months. }\end{array}$ & Expect 2000 points eventually. & October 13,1980 \\
\hline $\begin{array}{l}\text { Barnesville Electric } \\
\text { Departunent }\end{array}$ & $\begin{array}{l}\text { Raloh Barron, city Super intendent } \\
\text { (104) } 358-0181\end{array}$ & SA & $A C$ & 400 & Systermwide & In service & None & $\begin{array}{l}1100 \mathrm{~kW} \text { load reduction in first } \\
\text { year of operation. }\end{array}$ & October 21, 1980 \\
\hline $\begin{array}{l}\text { Camilla Electric } \\
\text { nepartment }\end{array}$ & $\begin{array}{l}\text { Ron Ratuui, city Manager } \\
(992) \text { J36-5636 }\end{array}$ & SA & ${ }_{A C}$ & 325 & Systernwide & In service & None & $\begin{array}{l}1.5 \mathrm{k} / \mathrm{kwi} \text { ich, } 2 \text { estimated first } \\
\text { year sovings } 827,000 \text {. }\end{array}$ & October 15, 1980 \\
\hline $\begin{array}{l}\text { Colauitt Electric } \\
\text { Membership Corporation }\end{array}$ & $\begin{array}{l}\text { Lamar Norman, Apparatus Supervisor } \\
\text { (912) }\end{array}$ & SA & $\mathrm{AC}-\mathrm{WH}$ & 8,000 & Systermwide & In service & None & $10,000 \mathrm{~kW} \mathrm{saved} \mathrm{surmer}$ of 1980. & October 13, 1980 \\
\hline City of Forsyth & $\begin{array}{l}\text { Richard Truitt, Mayor } \\
\text { (912) } 994-5640\end{array}$ & SA & WH & 700 & Systeriwide & In service & None & $\begin{array}{l}\text { Expect to add } 1,000 \text { motel } \\
\text { window AC in } 1981 .\end{array}$ & October 21, 1980 \\
\hline $\begin{array}{l}\text { Longn Island Liglting } \\
\text { Company }\end{array}$ & $\begin{array}{l}\text { Fred wilcox, Supervison, Meter Engineering } \\
\text { (516) } 733-4584\end{array}$ & SA & WH-AC-PP-MR & 1,000 & Systemwide & In service & $\begin{array}{l}\text { Seecial To0, seasonal and } \\
\text { tecmperature-depencentent rate }\end{array}$ & $\begin{array}{l}\text { Mandated for residential customers } \\
\text { over } 15,000 \text { kwhh year. }\end{array}$ & Septenber 10,1980 \\
\hline $\begin{array}{l}\text { Moultrie e a terer and } \\
\text { Light Department }\end{array}$ & $\begin{array}{l}\text { 8ob Roberson, } \text {, itty Manager } \\
(992)(985-1974\end{array}$ & SA & AC & 700 & Systenwide & In servire. & None & $\mathrm{N} / \mathrm{A}$ & October 28. 1980 \\
\hline $\begin{array}{l}\text { New Hamphire Electric } \\
\text { Copperative }\end{array}$ & $\begin{array}{l}\text { Don Gordon, Load Management Advisor } \\
\text { (603) } 536-1800\end{array}$ & SA & wH-SH & 500 & Demonstration & In service & None & $\begin{array}{l}\text { Project eventual expansion to } \\
20,000 \text { points. }\end{array}$ & September 25, 1980 \\
\hline $\begin{array}{l}\text { Nemman water and Light } \\
\text { Commission }\end{array}$ & $\begin{array}{l}\text { Meyman Jenkins, Customer Service } \\
\text { (404) } 253-5516\end{array}$ & SA & AC & 500 & Systenvide & In service & None & $925 \mathrm{kw}$ demand reduction. & October 15, 1980 \\
\hline $\begin{array}{l}\text { Soage Municical L Light and } \\
\text { Power Department }\end{array}$ & 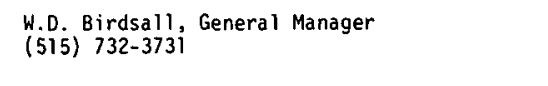 & SA & AC-WH & 800 & Systenwide & $\begin{array}{l}\text { Partially } \\
\text { in service }\end{array}$ & None & $N / A$ & September 25, 1980 \\
\hline Redding Electric Utility & $\begin{array}{l}\text { Jim Simpson, Director, Electric } \\
\text { oepoptrtent } \\
(996) 246-1151\end{array}$ & SA & $A C-\mathrm{KH}$ & 150 & Demonstration & On order & None & $N / A$ & October 28, 1980 \\
\hline $\begin{array}{l}\text { Soutth Caroi ina E lectric } \\
\text { and Gas company }\end{array}$ & 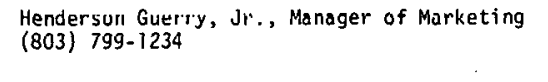 & SA & $A C-S H-W H$ & 25 & Demonstration & In service & $\$ 10 /$ month & $N / A$ & June. 19,1979 \\
\hline $\begin{array}{l}\text { Southern Cal iffornia } \\
\text { Edis son Cunnudily }\end{array}$ & $\begin{array}{l}\text { E.A. Myers, Jur., Vice President } \\
\text { (2i3) } 572-2001 \text {. }\end{array}$ & SA & WH-AC & 23,000 & 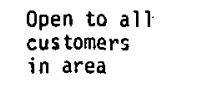 & In service & 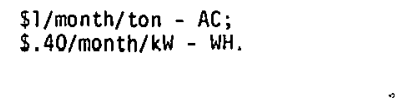 & Estimate $5 \mathrm{MW}$ peak reduction. & May 2, 1980 \\
\hline $\begin{array}{l}\text { Sylacauga Utili ities } \\
\text { Board }\end{array}$ & $\begin{array}{l}\text { Dale Baker, Secretary, Utilities Board } \\
(\langle\mathrm{uvs}) 249-8501\end{array}$ & SA & $A C$ & 900 & Systemwide & In service & None & First year savings - $\$ 45,000$ & September 25, 1980 \\
\hline 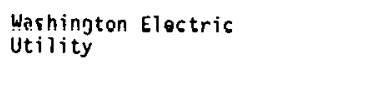 & $\begin{array}{l}\text { Dave Laurence, Load Managenent Supervi isor } \\
\text { (999) }\end{array}$ & SA & AC-WH & 1,200 & Systemwide & In service & 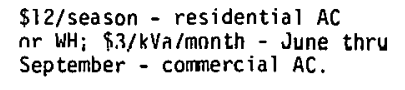 & First year savings $-\$ 80,000$ & October 14, 1980 \\
\hline
\end{tabular}

Legend 
THIS PAGE

WAS INTENTIONALLY

LEFT BLANK 
COLQUITT ELECTRIC MEMBERSHIP CORPORATION P. 0. Box 440

Moultrie, Georgia 31768

NEW 1980

Lamar Norman, Apparatus Supervisor

SYSTEM: $\quad$ Combination Radio and Power Line Carrier

SUMMARY: This systemwide program of air conditioner and water heater control has just completed its second year of operation. The primary objective of the program is the reduction of wholesale power costs by reducing the Colquitt Electric Membership Corporation's peak, coincident with the Georgia territorial peak. Air conditioners are cycled off $25 \%$ during peak periods and water heaters are controlied as necessary.

FUNCTION: Cycle central air conditioners and electric water heaters.

EQUIPMENT: Scientific Atlanta hybrid systems. Three transmitters with microwave links.

SAMPLE: Available to all customers. Presently have 8,000 loads under control with an approximate fifty/fifty mix of air conditioners and water heaters. Expect 12,000 points of control ultimately.

INCENTIVE: None.

INTERV IEW

DATE: $\quad$ October 13, 1980.

STATUS: In service.

RESULTS: $\quad$ During the 1980 summer peak, peak demand was reduced by an estimated $10 \mathrm{MW}$. 
LONG ISLAND LIGHTING COMPANY

250 old Country Road

Mineola, New York 11501

NEW 1980

Fred Wilcox, Supervisor, Meter Engineering

SYSTEM: $\quad$ Combination Radio and Power Line Carrier

SUMMARY: Long Island Lighting Company has installed a Scientific Atlanta hybrid radio-power line carrier system to switch meter dials, activate peak alert signal devices, and, where installed at customers' optional expense, activate load shedding devices on water heaters, air conditioners, and/or pool pumps. Residential customers who use over 45,000 kWh per year are subject to a mandatory time-of-use rate. The dial change, red alert, and load shedding will be activated when outdoor temperatures reach $81^{\circ} \mathrm{F}$ during 10:00 a.m. to 10:00 p.m. peak hours, except Sundays, June 1 through September 30 .

FUNCTION: $\quad$ Switch meter dials, change three-light alert to yellow and then to red when temperature reaches $81^{\circ} \mathrm{F}$ in June 1 to September 30 season, 10:00 a.m. to 10:00 p.m. Yellow alert is activated one hour before meter dial change. Customers who desire protertion when away may install load shedding devices on water heaters, air conditioners, and/or pool pumps at a cost of $\$ 135$ for the first point and $\$ 110$ for each additional point.

EQUIPMENT: Three-dial meters - one records total kWh use, one records 10:00 p.m. to 10:00 a.m. kWh use, and one records kWh use during high-temperature periods when radio signal activates it. Scientific Atlanta hybrid radio system including one controller, five transmitters, 1,000 receiver-injectors, 1,000 Scientific Atlanta customer alert devices, and a quantity of Scientific Atlanta load shedding devices. 
SAMPLE: $\quad$ One thousand customers who use over $45,000 \mathrm{kWh}$ in a year.

INCENTIVE: New York Public Service Commission-filed mandatory rate 10:00 p.m. to 10:00 a.m., June through September, 3.26ф per kWh plus fuel adjustment; October through May, $3.12 \phi$ per kWh plus fuel adjustment; 10:00 a.m. to 10:00 p.m., 12 months, $4.62 \notin$ per kWh pius fuel adjustment; $81^{\circ} \mathrm{F}$ high temperature, June through September, $30.62 \$$ per kWh plus fuel adjustment.

MONITORING: Cyclometer on each receiver indicates to meter reader during monthily visit that the date and hour is correct, thus verifying that system is operable.

INTERVIEW

DATE:

September 10, 1980.

STATUS:

In service since January $1,1980$.

RESULTS:

Not yet determined.

REMARKS: A small number of receiver-injectors are pole-mounted where added height is needed for good signal reception. 
SOUTHERN CALIFORNIA EDISON

P.0. Box 800

Rosemead, California 91770

NEW 1980

(213) $572-2001$

E. A. Myers, Jr., Vice President

SYSTEM: $\quad$ Combination Radio and Local Control

SUMMARY: $\quad$ Southern California Edison Company's "Demand Subscription Service" (DSS) is a concept that will allow a customer to choose the minimum level of service to satisfy his comfort needs during critical system capacity shortage periods. The demand limiting device is installed al lhe cuslomer's meter and is radio-controlled. When activated, normally during system capacity shortage situations, the device will trip the total house load only. if the previously subscribed level of demand is exceeded. The customer may manually reset the circuit breaker only after reducing the household load below the subscription lever.

FUNCTION: $\quad$ To activate the DSS device during system capacity shortage periods. Two thousand units will be activated between 12:00 nuvil and G:00 p.m. during the summer months; 300 will be activated during peak periods all year; and 300 will be activated all the time. The device, when activated, will trip the total house load if the previously subscribed demand level is exceeded.

EQUIPMENT: Scientific Atlanta and Sangamo demand limiting switches and message generating units for transmitting codes. 
SAMPLE: $\quad$ Two thousand six hundred residential customers in newly constructed homes in three weather zones. Their participation will be solicited when applying for electric service.

INCENTIVE: Between $\$ 0$ and $\$ 24 /$ month, dependent upon demand leve and major appliance mix.

MONITORING: $\quad$ Six hundred and fifty magnetic tape recorders installed on individual customer meters. Two hundred and fifty remote meter reading devices.

INTERV IEW

DATE:

July 1, 1980.

STATUS: $\quad$ System to be operational by summer 1981 .

RESULTS: $\quad$ Not yet available. 
SOUTHERN CALIFORNIA EDISON COMPANY

P.0. Box 800

Rosemead, California 91770

REVISED 1980

E.A. Myers, Jr., Vice President

SYSTEM: $\quad$ Combination Radio and Power Line Carrier

SUMMARY: In the four communities of Leisure World, Laguna Terrace, New World, and Willows, about 13,000 residential customers are served by a special geographically bound rate, approved by California Public Utility Comission on August 23, 1977, under which their water heaters and air conditioners are controlled by a cumbillaliun radlu and carrler wave system. There are approximately 23,000 control points in these r.nmmunities. From the General office in Roscmcad through a transmitter on Loma Ridge, a radio signal is sent to receivers located in $6 \times 4 \times 9$-inch extended meter boxes on one house for each group of homes on a single secondary. From the receiver, the signal is transferred to carrier current on the secondary cables on the underground distribution system. As necessary, on-peak days water heaters are switr.hed off for five to six hours and air conditioners for up to fifteen minutes per half-hour.

FUNCTION: $\quad$ To cycle water heaters and air conditioners on peak days for load reduction during system peak periods.

EQUIPMENT: Scientific Atlanta, Inc. Peak Load Management.

SAMPLE: Voluntary for all present and new customers in area.

INCENTIVE: $\quad \$ 1$ per month per ton of air conditioning; $\$ .40$ per month per $\mathrm{kW}$ of water heating.

MONITORING: Substation instruments and regular service meters. 
INTERV IEW

DATE:

May 2, 1980.

STATUS:

In service.

RESULTS: $\quad$ Project a peak load reduction of $5,000 \mathrm{~kW}$ based on 215 watts per water heater, 260 watts per central air conditioner, and 170 watts per window air conditioner. Final report due first quarter 1980. 


\subsection{TELEPHONE}

\section{Technical Characteristics}

A telephone communication and load control system is essentially a bidirectional system that utilizes existing telephone lines as the medium for transmitting signals. This system is still experimental, but is gaining attention among utilities. Structurally, a telephone C\&LC system is composed of the same major components as any other C\&LC system. However, in a telephone system, the central control and some point-ofcontrol equipment is owned by the electric utility, while the transinlssiun and major point-of-control equipment is owned by the telephone company.

The telephone C\&LC system operates in the following manner:

- Utility system data is fed into a typically computer-based central control unit. The data may originate from external monitoring devices or from the C\&LC system points of control. The data is then analyzed and compared to preprogrammed setpoint parameters. Load management or automated distribution functions are initiated when one of these setpoints is exceeded. The commands are encoded and then sent to the telephone company via a telemetry link.

- At the telephone company's central switching office, the commands are received by a subscriber communication (SCM) computer. The SCM interfaces with the telephone company's Central office Controller $(C O C)$ and commands the $C O C$ to transmit the load management commands over the proper telephone lines to the desired point-ofcontrol.

- At the point of control, a Subscriber Communication Interface Unit (SCI) receives the command signal. The SCI is connected in series with the telephone line and customer's telephone, and monitors the telephone line for command signals. The SCI is a micro-processorcontrolled device that incorporates a signal decoder/encoder, and can interpret the signal commands and take action. The SCI unit interfaces with the telephone, and.an Energy Management Module (EMM) that contains data accumulators, time-switching outputs, 
and logic for meter reading and direct load control. The EMM. operates point-of-control relays to perform the desired functions.

Signal reception reliability in telephone C\&LC systems is very high because telephone systems are designed for communication. Privacy of the consumer's telephone line is maintained since access remains under the control of the telephone company rather than the utility.

\section{System Costs}

The structure of a telephone C\&LC system, with its unique ownership setup, makes a costing analysis, of the type presented thus far, difficult. The total per point cost of a utility-owned and operated C\&LC system has been shown to be the total of the installed costs of all control, transmission, and receiver-transponder equipment, divided by the number of points of control found or expected to be found within the system. In a telephone C\&LC system, the cost that a utility could expect to experience on a total installed per point basis would be a function of the installed costs of central control apportioned out by the number of control points, plus the average per point installed costs of any nontelephone company equipment (meter encoders, wiring, etc.), plus the average per point service and usage costs associated with the charges levied by the phone company for providing the communication system. The installed costs of the utility's central control system can vary considerably, depending upon the required level of sophistication, etc., as was the case with other types of C\&LC systems. These costs can vary from just a few thousand dollars for a small CRT interface to several hundred thousand dollars for a sophisticated, high-powered computer system. The utility-incurred costs at the point of control would involve the purchase and installation of a meter encoder (if remote meter reading would be desired), the running of low-voltage control lines from the Energy Management Module (for low-power switching such as air conditioner control via thermostat lines), and/or the installation and wiring of higherpowered contactors for use with heavier load switching (e.g., water 
heaters).

The final costing element in a telphone C\&LC system would be the service and usage charges levied by the telephone company. These costs would also be expected to represent the most significant cost elements of the system. For example, if the service charge alone (assuming usage costs to be analogous to operating costs) averages $\$ 3$ per month per point, this cost would represent a cost on a present worth bas is $(12 \%$ discount over 15-year life cycle) of approximately $\$ 250$ per point.

Both the equipment manufacturer and telephone company. personnel were contacted in an effort to determone what these service and usage charges were likely to be for a commercial system. Neither, however, was in a position to predict what these costs would eventually be.

As such, it is difficult to project what the typical per point costs will be for this type of system. It can be expected, however, that, as the system approaches the commercial stage, these costs will eventually come into focus. 


\section{$2-141$}

Telephone C\&LC Equipment Manufacturers

Harris-Darcom

6100 Kircher N.E.

Albuquerque, New Mexico 87109 
$2-142$

\section{THIS PAGE}

WAS INTENTIONALLY

LEFT BLANK 
Table 2-11

Telephone Projects Sumnary

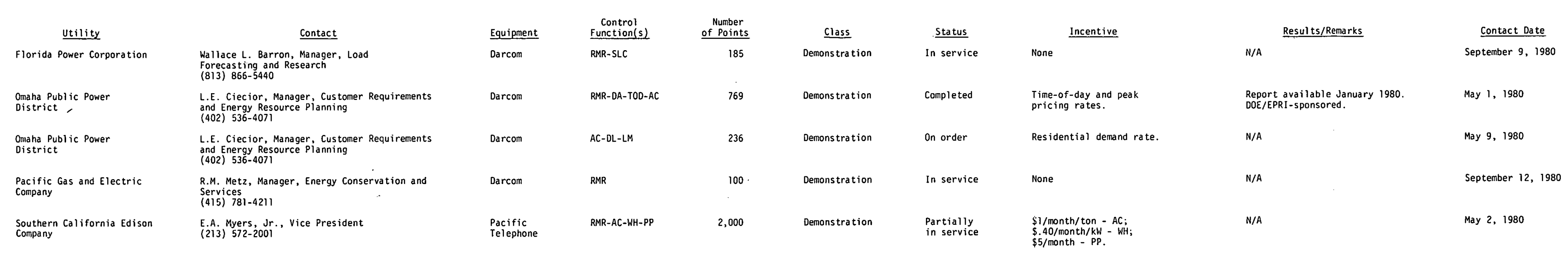

Legend

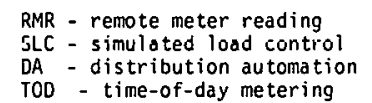

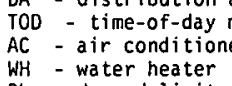

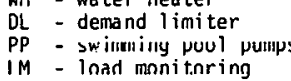


THIS PAGE

WAS INTENTIONALLY

LEFT BLANK 
OMAHA PUBLIC POWER DISTRICT

1623 Harney Street

NEW 1980

Omaha, Nebraska 68102

(402) $536-4071$

L.E. Ciecior, Manager - Customer Requirements and Energy Resource Planning

SYSTEM: $\quad$ Telephone

SUMMARY: Omaha Public Power District, in a joint venture with DOE, will collect and evaluate data to determine the effects of controlling residential customer loads. The District has DARCOM remote metering equipment that will be utilized to provide a real-time communication link to control equipment.

There will be 186 customers participating in the air condition portion of the experiment. Half of them will have their air conditioners controlled and the other half will have their air conditioners monitored. Both groups will have household load and air conditioner runtime data collected by the remote monitoring equipment. In addition, 45 of the controlled customers will have their indoor temperature recorded at 15-minute intervals.

Fifty customers will participate in the Demand Limiter portion of the experiment. The customer will have the ability to adjust his maximum demand level to best satisfy his personal requirements. In addition, the District will have the capability of reducing the customer set limit. The demand limiter will optimally control and schedule electric furnaces or air conditioners, electric hot water heaters, and electric dryers.

FUNCTION: From one telephone central office, data is relayed over the switched telephone network to the customer's regular 
telephone pair. The transmissions are audible and two-way communications are feasible when customers' telephones are not in use. A retry program keeps track of busy lines and accesses them when they are not in use. Load control signalling is transmitted over a busy line. The customer hears a short audible tone burst when the signal is sent.

EQUIPMENT: Dencor, Inc. - demand limiter. Remote monitoring equipment - DARCOM.

SAMPLE: $\quad 236$ residential customers.

INCENTIVE: The 186 controlled and monitored customers will have no incentive. The 50 demand-limited customers will be billed according to a residential demand rate.

INTERVIEW

DATE:

May 9, 1980.

STATUS: $\quad$ [quipment is scheduled lo be irslatled in winter-spring 1981.

R[SULTS: No data avãi]able. 
OMAHA PUBLIC POWER DISTRICT

1623 Harney Street

Omaha, Nebraska 68102
REV ISED 1980

(402) 536-4071 -

L. E. Ciecior, Manager - Customer Requirements and Energy Resource Planning

SYSTEM:

Telephone

SUMMARY :

DOE/EPRI-sponsored 769-point field trial is testing communication systems for distribution automation, remote meter reading, time-of-day metering, air conditioner load control, peak pricing rate control, and warning signal at customer premise. Twenty-two customers have air conditioner control while thirty customers have simualted air conditioner control to evaluate the energy reduction potential. Twentyfive customers on a peak pricing rate have a two-light indicator panel in their residences. On days when peak system demand is forecast, the amber light is activated, and between the hours of 2:00 p.m. and 9:00 p.m., the red light illuminates, denoting an increase in the cost of energy. All other remote metering locations have electronic load control accumulating registers to monitor the receipt of the load control signals. Time-of-day electronic accumulators measure $\mathrm{kWh}$ used during these periods of the day: 5:00 a.m. to 9:00 a.m., 9:00 a.m. to 3:00 p.m., and 3:00 p.m. to 10:00 p.m. Air conditioners are cycled off for 7-1/2 minutes each half-hour during days of peak generating demand. Utilizing a mass address scanner, all customers can be shed in a maximum of 50 seconds. Through coordination with the Metropolitan Utilities District, gas and water meters are also being read remotely. Installation was made, utilizing the team concept that Omaha Public Power District, Municipal Utility District, and Northwestern Bell personnel working together as a team, minimizes installation costs. 
FUNCTION: $\quad$ From one telephone central office, data is relayed to remote points over the switched telephone network to the customer's regular telephone pair. The transmissions are audible and two-way communications are feasible when the customer's telephone is not in use. A retry program keeps track of busy lines and accesses them when the line is not in use. Load control signalling is transmitted over a busy line. The customer hears a short audible tone burst when the signal is sent.

EQUIPMENT: $\quad$ DARCOM Marlayemenl Systenls.

SAMPLE: $\quad 572$ residential, 125 apartment, 55 commercial/industrial. Seven power interchange metering points. Four sectionalizing switch control points. One capacitor control point. Five substation control and monitoring locations (twenty points at each location). Total of 769 remote locations. The test area has overhead and underground power and telephone lines and provides a good mix of rural, urban, and commercial customers.

INCENTIVE: Voluntary time-of-day and peak pricing rate. Customer guaranteed that the annual cost of electricity for a oneyear test will not exceed the conventional residential rate.

MONITORING: Accumulators, meter encoders, and meters on premise; weather information obtained from Offutt Air Force Base weather station. Mag tape metering of distributor transformer secondaries to monitor the effect of air conditioner load shedding on transformer loading and relationship to temperature.

INTERV IEW

DATE:

May 1, 1980. 
STATUS: $\quad$ One-year test and evaluation period completed July 37, 1979.

RESULTS: $\quad$ Report of one-year test and evaluation of the systems will be available January 1981.

REMARKS: $\quad$ Meter reading and control signals are sent during all hours of the day and night to evaluate the effects of telephone traffic on system operation. System controller logs busy lines for later inquiry. Load control and peak pricing signals are sent over a busy line and are audible to the customer. 
PACIFIC GAS AND ELECTRIC COMPANY

REVISED 1980

77 Beale Street

San Francisco, California 94106

(415) $781-4211$

R.M. Mertz, Manager, Energy Conservation and Services

SYSTEM: $\quad$ Telephone

SUMMARY: The purpose of this experiment is to test the hardware for a feasibility and compatibility study of a telephonebased energy management system. This system has capabilitops which can be used both by the phune cumpally and the electric utility. The test will be remote meter reading and simulated load control.

EQUIPMENT: DARCOM telephone line carrier. Central computer at the telephone central office. At each switching center there is another computer and at the subscriber's residence there is a communication interface unittransponder.

SAMPLE: $\quad$ The proposed test includes 100 transponders (200 customers), ten of which are to be installed in apartment houses reading an average of ten meters each, with the remaining 90 transponders installed at single-family dwellings.

INCENTIVE: None.

INTERVIEW

DATE:

Septemher 12, 1980.

STATUS: $\quad$ [quipment is installed and operating.

RESULTS: The two-way communication system is working we11. Detailed data is currently being collected. 
SOUTHERN CALIFORNIA EDISON COMPANY

REVISED 1980

P.0. Box 800

Rosemead, California 91770

(213) $572-2001$

E.A. Myers, Jr., Vice President

SYSTEM: $\quad$ Telephone

SUMMARY: $\quad$ Southern California Edison Company's "Automatic Powershift Program," utilizing Pacific Telephone Company lines to carry automated control signals to about 2,000 Valencia volunteer residential customers, will cycle water heaters, air conditioners, and swimming pool filter pumps. The system will have automatic remote meter reading capability.

FUNCTION: $\quad$ To cycle air conditioners up to ten minutes out of every forty minutes, water heaters up to three hours, and swimming pool filter pumps up to one hour out of every two hours; all general1y between 11:00 a.m. to 7:00 p.m. on summer weekdays.

EQUIPMENT: Pacific Telephone-owned transponders and computers, Southern California Edison-owned load switches and special metering, and Southern California Edison-rented terminal equipment.

SAMPLE: $\quad 2,000$ volunteer residential customers solicited by mail and personal contact in Valencia.

INCENTIVE: $\quad \$ 1.00$ per month per connected ton of central air conditioning; $\$ 0.40$ per month per connected kW of electric water heating; $\$ 5.00$ per month per connected swimming pool filter pump. 
MONITORING: By automatic meter reading capability via the Pacific Telephone Valencia-Newhall exchange to Southern California Edison headquarters.

INTERVIEW

DATE:

May 2, 1980.

STATUS: $\quad$ System to be furly operational by mid-1980.

RESULTS: $\quad$ Not yet determined. Previous cycling tests on hundreds of homes showed that customers were seidom aware that. appliances were being cycled. 


\subsection{LOCAL CONTROL}

\section{Technical Characteristics}

Local controllers are load control devices that incorporate a switching function into some level of local, on-site logic. These devices, which include everything from mechanically programmable time switches to sophisticated microprocessor-based load control systems, differ from the familiar receiver switch of a remote communication system in that they are designed to carry out load control functions without remote stimulus and/or in a fashion more involved than simple on-off switching.

Local controllers are all designed to limit or defer loads within a particular location. They differ, however, in the method or level of load control exercised. The methods of operation of the major types of these devices will be described in following sections. Local controllers also differ in the manner in which each device is activated. This method of activation is important because it determines when control is to be exercised as opposed to how it will be exercised. Basically, local controllers can be placed into one or more of three categories according to their method of activation. These categories are site-specific activation, time-specific activation, and direct utility activation.

Local controllers that operate under site-specific activation are primarily designed to limit the peak demand of a location without regard to coincidence with the utility's peak. As such, the load management potential of such devices, in terms of limiting coincident peak demand, is also sitespecific. For example, if the peak demand of a location is coincidental with the utility's peak, then deferring or limiting load within that period would be expected to have a positive impact on the utility's peak demand. If, however, the peak demand of the location is non-coincidental with the utility's peak, then the deferral of loads at the time of the location's non-coincidental peak could conceivably adversely affect the utility's situation by deferring loads into the utility's peak time. Although normal system diversity would be expected to more than compensate 
for these adverse effects by seeing that more loads are deferred from on-peak to off-peak periods than vice-versa, site-specific control may at times result in non-constructive control. The exception to this would be when the customer is charged a demand rate, in which case control is always constructive, at least for the customer.

Time-specific activation refers to those local controllers that perform their designed load deferral or load limiting functions only during certain times of the day. Time-specific controllers may also operate under site-specific conditions, such as when demand exceeds prescribed limits, but only during those hours defined by the utility as being peak hours. The earliest example of time-specific control is the mechanically programmable clock switch that utilities use to turn off a customer's water heater during certain hours of the day. Several more sophisticated devices, which are either specifically designed for, or adaptable to, time-specific activation are presently available. These timespecific devices allow a utility to tailor its load management needs according to historical load patterns, but offer limited flexibility in the face of changing seasonal or annual load patterns. Such changes would require occasional reprogramming of the time-specific devices.

Direct utility activation devices are local controllers that are capable of interfacing with a utility C\&LC system like radio, ripple, or power line carrier. This type of activation offers a utility the highest degree of flexibility in determining how, when, and how much control is exercised at the local level, and a more sophisticated level of control than would be possible using only a receiver switch or local controller. This type of activation logically also represents the highest level of cost, since it requires both a communication system and local controllers. Three major types of local controllers are described in the following sections. Along with a functional description of the devices, the activation capabilities and costs of the devices are included wherever such information is available. 
Priority Relay/Appliance Interlock. One of the simplest forms of local control is the priority relay. A priority relay, or "interlock" as it is often called, is a device that is designed to limit the maximum demand in any given home by preventing two or more high-load appliances from being used at the same time. The device monitors the current draw on a priority, or non-interruptable, load by means of a current transformer or other type of sensing device. When the priority load is turned on or when the current draw of the priority load exceeds a preset maximum, the device cuts off power to an interruptable load. When the priority load is turned off, the device restores power to the interruptable load. This action effectively prevents both loads from 'coming on at the same time and as such, limits, in theory, the maximum potential non-coincident demand of the home by a value equal to the smaller of the two connected loads. In other words, if the device interlocks a 5-kW electric dryer as the priority load with $4.5-\mathrm{kW}$ water heater as the interruptable load, then the maximum potential non-coincident demand of the home would theoretically be reduced by $4.5 \mathrm{~kW}$. Although this postulation would be true in terms of limiting instantaneous or "needle" peak demands, the effect this device would have on the billing period demands of the home (measured over a 15-or 30-minute period) would be expected to be somewhat less than $4.5 \mathrm{~kW}$. This is due to the cyclic nature of the interlocked appliances, particularly the dryer.

Preliminary results from one utility test of these devices show that when interlocking a 5-kW dryer with a $4.5-\mathrm{kW}$ water heater, an average peak non-coincident demand reduction of $1.7 \mathrm{~kW}$ results.

It is significant to note that since the device operates in a sitespecific manner to limit loads, its potential for limiting demand coincident with a utility's peak is difficult to evaluate.

At least two manufacturers are involved in the development and sale of this type of device. In both cases, the price of the device is presently or projected to be $\$ 40$ with an estimated installation cost of $\$ 15$. 
Programmable Demand Limiters. Programmable demand limiter is a generic term describing several devices that allow a utility or consumer to limit demand at a particular location by cycling loads or deferring loads according to preset programmed scenarios.

These devices are capable of controlling multiple loads in several different ways. For example, when the device is activated, its program may instruct it to first shut off the electric water heater. If more control is required, the device may cycle the heating or air conditioning system. It may also cycle, or turn off other appliances or loads and/or alert the consumer of a high demand or peak condition. The activation system for this type of local controller can be sitespecific, time-specific, or direct utility. It can also be a combination of two or more types. For example, the device can be set up to control loads whenever demand exceeds allowable limits, but then only within certain hours of the day. Once it is activated, the device will continue its load management functions until its activation system calls for it to stop.

Devices of this type have been used for years in commercial and industrial applications as a means of reducing or minimizing monthly demand charges. Recently, several manufacturers have developed devices of this type for residential use. The installed cost of these devices typically ranges from $\$ 700$ to $\$ 1,300$.

Eoad Management Thermostats. Load management thermostats are thermostats that automatically alter the temperature settings within a location in a manner that best serves the needs of the utility's load pattern. At least two devices of this type have been the object of utility experimentation within the past few years. One of these thermostats was developed at Pacific Gas and Electric Co. (Pli\&t) tor use with non-residential customers, and one device has been developed at Potomac Edison Co. (PE) for residential applications. The devices both operate on the same general principle of load management as those utility projects involving the remote cyclic 
control of air conditioners and/or heating systems. In a program of remote cycling, the principle benefit derived by the utility is that during those hours of high demand, relief can be obtained by remotely reducing the normal duty cycles of customers' air conditioners or heating systems by means of controlled cycling.

Reducing the normal duty cycles of these appliances reduces the diversified demand of these applicances and, hence, offers some measure of load relief. By reducing the normal duty cycles of a consumer's air conditioner, some degradation of comfort conditions can be expected to take place.

One major problem exists in the utilization of remote cycling. Most, if not all, remote cycling projects operate on time control. In a program of cycling air conditioners, for example, each consumer has his unit shut off for some period of time each hour. The typical cycling scenario for residential air conditioners has been 7-1/2 minutes off each half hour or fifteen minutes off each hour, regardless of the conditions existing at each home. This non-discriminate, time-based cycling can produce less than optimum results because of the wide variations in the types and sizes of air conditioners under control. For example, if a customer's air conditioner is oversized, cycling it off for fifteen minutes may produce little or no net load deferral because its normal cycling, based on the temperature setting selected by the customer, may already cycle the system off for fifteen or more minutes. On the other hand, if a customer's air conditioner is marginally sized, a fifteen minute shut-off per hour could result in overcontrol, that is, temperature degradation greater than what the customer is willing to tolerate.

As mentioned earlier, load management thermostats operate on much the same principle as that of remote cycling programs. The major difference is that load management thermostats control the duty cycle of a heating or cooling system by directly controlling the temperature settings in the homes. By exercising control in this manner, the 
utility can theoretically achieve the maximum amount of load relief attainable without subjecting the customer to unacceptable temperature degradation.

The device developed at Pacific Gas and Electric, called the "smart thermostat," is designed to reduce the demand of commercial air conditioning systems by placing the temperature setting of commercial customers in the hands of the utility via remote control. Using a remote communication system, in this case radio, PG\&E can increase the temperature settings of these controlled customers in $1.5^{\circ} \mathrm{F}\left(.8^{\circ} \mathrm{C}\right)$ per hour steps to a maximum setting of $82^{\circ} \mathrm{F}\left(27.7^{\circ} \mathrm{C}\right)$.

According to its manufacturer, the present cost of this thermostat is $\$ 220$, not including the cost of the radio receiver. The projected cost of this device, including an integral communication (radio carrier) receiver, is between $\$ 130$ and $\$ 150$.

The device, developed at Potomac Edison Co., is designed for residential applications. This device is a pre-programmed, solid-state thermostat capable of site-spécific, time-specific, and/or direct utility activation. The device performs its load management functions by controlling internal temperature settings in a unique way. In an application of residential electric heat control, the device operates in the following manner: starting two hours prior to the onset of pedk conditions, as defined by the utility through the use of time-specific or direct activation, the device acts to preheat the home to a level $4^{\circ} \mathrm{F}\left(2.2^{\circ} \mathrm{C}\right)$ higher than the normal temperature setting of the home; at the onset of the peak period, the device shuts off the heating system and allows the temperature in the home to slowly drop to a pre-determined minimum setting. This action reduces the duty cycle of the heating system, but within defined temperature constraints. The device can also interface with an outdoor thermostat so that it will only perform its cycling functions when ambient temperatures are below certain levels, adding site-specific activation capabilities.

For use in controlling air conditioners, the device has the capability of precooling the home by some fixed amount and then, during peak 
periods, allowing the temperature to rise $1^{\circ} \mathrm{F}\left(.56^{\circ} \mathrm{C}\right)$ every 80 minutes to a maximum level $5^{\circ} \mathrm{F}\left(2.8^{\circ} \mathrm{C}\right)$ higher than normal settings.

The ability of the device to preheat or precool the home and then allow a gradual temperature decline or increase, permits the load to be shifted into periods both before and after peak periods. This preheating and precooling also provides a wider, tolerable temperature range through which the house can fluctuate than that which would be possible without preheating or precooling.

The present cost of this device is $\$ 150$; but the manufacturer projects that this cost will drop to approximately $\$ 100$ once the device is in volume production. 
Local Controller Equipment Manufacturers

Dencor Inc.

2750 S. Shoshone

Englewood, Colorado 80110

General Electric

Appliance Control Dept.

Morrison, Illinois 61270

General Electric Industrial Controls

1501 Roanoke Boulevard

Salem, Virginia 24153

Honeywe11 ronntrn! Systems

1700 West Highway 36

Roseville, Minnesota 55113

Horizon Solar Corporation

328 Link Lane

Fort Collins, Colorado 80522

M. L. Jameson Electric

Route 2 Box 85

Findlay, Ohio 45840

Metretek Incorporated

$724 \mathrm{~A} E$. New Haven Avenue

Melbourne, Florida 32901

Peak Demand Limiters Inc.

P.0. Box 764

Golden, Colorado 80401

Phillips Control Corporation

\#7 Inverness Drive East

Englewood, Colorado 80110

Energy Management Division

P.0. Box 48400

Atlanta, Georgia 30362

Sentrol Energy Management Systems

317 Lincoln Court

Fort Collins, Colorado 80524

ZDC Incorporated

2305 Peak Avenue

Boulder, Colorado 80302 
Table 2-12

Local Control Projects Sumary

\begin{tabular}{|c|c|c|c|c|c|c|c|c|c|c|}
\hline $\begin{array}{l}\frac{U \text { tility }}{\text { Alfalfa glectric Cooperative }} \\
\text { Ela }\end{array}$ & $\begin{array}{l}\text { Contact } \\
\text { Oon Wessels, off } \\
\text { (405) } 596-3333 \text { Fice Manager }\end{array}$ & $\begin{array}{l}\text { Equipenent Type } \\
\text { Time and temper- } \\
\text { ature as witcch }\end{array}$ & $\begin{array}{l}\text { Equi pment } \\
\text { Manuffacturer } \\
\text { GE }\end{array}$ & $\begin{array}{l}\text { Control } \\
\text { funntion(s) } \\
\text { AC }\end{array}$ & $\frac{\text { of Pomber }}{\substack{\text { Neints } \\
80}}$ & $\begin{array}{l}\text { Class } \\
\text { Avai lable to } \\
\text { al1 customers }\end{array}$ & 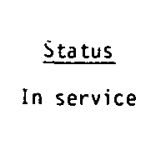 & s20/year & $\begin{array}{l}\text { Results/Remarks } \\
\text { Loadireduction } 1.5-2 \mathrm{~kW} \text { per } \\
\text { point. Poor customer response. }\end{array}$ & $\begin{array}{l}\text { Contact Date } \\
\text { June } 19.1979^{\circ}\end{array}$ \\
\hline $\begin{array}{l}\text { Arizona Public Service } \\
\text { Conpany }\end{array}$ & $\begin{array}{l}\text { Joseph Schill ing, Supervisor of Load } \\
\text { Research } \\
\text { (602) } 271-7900\end{array}$ & Demand Iinter & c & $\begin{array}{l}6 \text { major } \\
\text { appl innces }\end{array}$ & 100 & Demonstration & In service & $\$ 50$ payment plus denand rate & Not ýet avai lable. & July 26, 1979 \\
\hline $\begin{array}{l}\text { Black River Electric } \\
\text { cooperative }\end{array}$ & 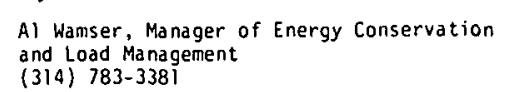 & Load cyclér & Coop design & S̈H-AC & 200 & One substation & In service & $4-8 \%$ savings & Not yet available. & September 5, 1980 \\
\hline Gulf Poner Company & 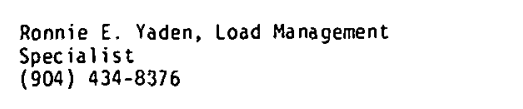 & $\begin{array}{l}\text { Load management } \\
\text { thermos tat }\end{array}$ & GE & AC-SH & 70 & Demonstration & In service & None & Not yet avai lable. & April 21, 1980 \\
\hline $\begin{array}{l}\text { Intermountain Rural } \\
\text { Electric Association }\end{array}$ & 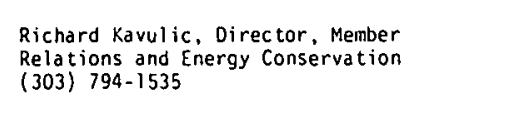 & Demand Iimiter & various. & SH-HH-MA & 340 & Sys tenrwide & In service & Residential demand rate & Not yet available. & August 15, 1980 \\
\hline $\begin{array}{l}\text { New York State } \\
\text { Electric and Gas }\end{array}$ & $\begin{array}{l}\text { Trudy yarren } \\
\text { (607) } 729-2551\end{array}$ & Demand I imiter & Unknown & SH-WH & 10 & Demonstration & $\begin{array}{l}\text { Partially } \\
\text { in service }\end{array}$ & None & Not yet available. & June 29, 1979 \\
\hline $\begin{array}{l}\text { Morthern States Power } \\
\text { Company }\end{array}$ & $\begin{array}{l}\text { Conrad J. Aas, Adminis stra tor, Research } \\
\text { probrans } \\
\text { (612) } 330-5566\end{array}$ & $\begin{array}{l}\text { Lad management } \\
\text { thermostat }\end{array}$ & н & $A C$ & 25 & Demonstration & In service & None & $\begin{array}{l}\text { Control lers are remoteiy } \\
\text { inititiated by radio. }\end{array}$ & August 14, 1980 \\
\hline Ohio Edison Company & $\begin{array}{l}\text { Justin T. Rogers, vice President } \\
\text { (216) } 384-5844\end{array}$ & $\begin{array}{l}\text { Priority relay } \\
\text { interlock }\end{array}$ & $\mathrm{s}$ & Wh & 500 & $\begin{array}{l}\text { Avai iable to } \\
\text { all customers }\end{array}$ & In service & Demand rate & 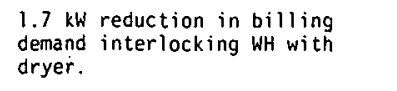 & January 19, 1978 \\
\hline $\begin{array}{l}\text { Okiahoma Gas and } \\
\text { Electric Company }\end{array}$ & $\begin{array}{l}\text { As Strecher, Manager, Consumer Services } \\
(405) \text { 2727-3000 }\end{array}$ & $\begin{array}{l}\text { Load mana gement } \\
\text { therrmostat }\end{array}$ & GE & AC & 600 & Demonstration & In service & $\begin{array}{l}\$ 2.17 / \text { VVa/month - July through } \\
\text { September }\end{array}$ & Not yet available. & September 17,1980 \\
\hline $\begin{array}{l}\text { Pacificic Gas and } \\
\text { Electric Company }\end{array}$ & $\begin{array}{l}\text { R.M. Mertz, Manager, Energy Conservation } \\
\text { and Services } \\
(415)(78)-4211\end{array}$ & $\begin{array}{l}\text { Load management } \\
\text { thermostat }\end{array}$ & н & 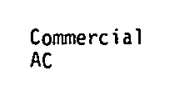 & 500 & Demonstration & In service & $\begin{array}{l}\text { \$1. } 50 / \text { ton/month - May through } \\
\text { September }\end{array}$ & Not yet available & September 16, 1980 \\
\hline $\begin{array}{l}\text { The Potomac Edison } \\
\text { Company }\end{array}$ & 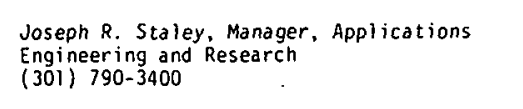 & $\begin{array}{l}\substack{\text { Lad managenent } \\
\text { thermons tat }} \\
\text {. }\end{array}$ & GE & SH-AC & 300 & Demonstration & Completed & \$100 over two years & $7 \mathrm{kw}$ 'demand reduction from $\mathrm{SH}$. & May 2, 1980 \\
\hline $\begin{array}{l}\text { Potomac Electric Power } \\
\text { Company }\end{array}$ & $\begin{array}{l}\text { A. Earl Keicher, Customer Services } \\
\text { (202) } 872-3019 \text { - }\end{array}$ & $\begin{array}{l}\text { Priority relay } \\
\text { interlock }\end{array}$ & AAS & WH & 30 & Demonstration & in service & $\begin{array}{l}\text { \$7. 35/month - May through } \\
\text { September. }\end{array}$ & Continuing through surmer 1980. & Apri1 24, 1980 \\
\hline $\begin{array}{l}\text { Potomac Electric Power } \\
\text { Company }\end{array}$ & $\begin{array}{l}\text { R.J. Hulshizer, Project Manager } \\
\text { (202) } 8 \text { 82-20000 }\end{array}$ & $\begin{array}{l}\text { Iime and temper- } \\
\text { ature switch }\end{array}$ & GE & $A C$ & 2 & Demonstration & in service & None & Not yet available. & August 13, 1980 \\
\hline $\begin{array}{l}\text { Southern Cali fornia } \\
\text { Edison Company }\end{array}$ & $\begin{array}{l}\text { E.A. Myers, Jr., Vice President } \\
\text { (213) S72-2001, Vicher }\end{array}$ & Derand limiter & s & $\begin{array}{l}\text { Total house } \\
\text { load }\end{array}$ & 2,000 & Demonstration & Planning & - so to $\$ 24 /$ month & Not yet avai lable. & July 1, 1980 \\
\hline $\begin{array}{l}\text { Tennessee valley } \\
\text { Authority }\end{array}$ & 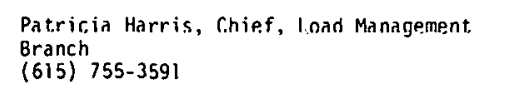 & $\begin{array}{l}\text { Inad management. } \\
\text { thermos tat }\end{array}$ & TI & ACCSH & 4 & Demonstration & Planning & Too rate & Not yet available. & April 28, 1980 \\
\hline
\end{tabular}

Legend

AC - air conditioner control
SH - space heat ing control
SH

wh- water reater control

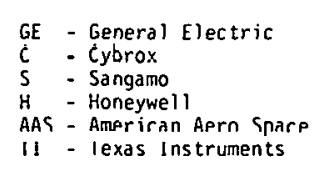


THIS PAGE

WAS INTENTIONALLY

LEFT BLANK 
INTERMOUNTAIN RURAL ELECTRIC ASSOCIATION

2100 West Littleton Boulevard

REVISED 1980

Littleton, Colorado 80120

(303) 794-1535

Richard Kavulic, Director of Member Relations and Energy Conservation

SYSTEM: $\quad$ Local Controllers

SUMMARY: $\quad$ Equipment from various manufacturers is used to reduce peak demand via control of space and water heating, electric clothers dryers, and some hot tub and air conditioning loads. Customer chooses and purchases equipment and pays for installation. Utility offers an optional residential demand rate and performs special monitoring on installations.

FUNCTION: Control space and water heating and some other appliances in order to reduce peak demand on system.

EQUIPMENT: Customer selects control equipment from five different manufacturers: Dencor, Phillips, Sentrol, Horizon-Solar, and Peak Demand Limiters, Inc.

SAMPLE: $\quad 340$ residential installations controlling various appliances.

INCENTIVE: Special demand rate $-\$ 10.50$ for first $\mathrm{kW}, \$ 2.50$ for each additional kW, and $1 \$$ per $\mathrm{kWh}$. Co-op offers customers lowinterest loans for purchase of hardware.

MONITORING: Utility monitors kW demand, kWh energy usage, and weather data to establish correlations among house type and size, type of control, season, and energy usage.

INTERV IEW DATE:

August 15, 1980. 
STATUS: On-going project; utility encouraging customer participation via advertising and bill enclosures.

RESULTS: $\quad$ Not yet available. 
PACIFIC GAS AND ELECTRIC COMPANY 77 Beale Street

San Francisco, California 94106
REVISED 1980

(415) $781-4211$

R. M. Mertz, Manager, Energy Conservation and Services

SYSTEM: $\quad$ Radio and "Smart Thermostats"

SUMMARY: Using Honeywell thermostats designed according to Pacific Gas and Electric specifications, 500 nonresidential customers will have indoor cooling controlled by radio, raising temperatures in up to eight increments of $1-1 / 2^{\circ} \mathrm{F}$ to a maximum of $82^{\circ} \mathrm{F}$ for load relief. The "Smart Thermostats" will replace customers' coriventional thermostats which control single-zone package unit air conditioners in sizes of $3-1 / 2$ to 50 tons. There are three operating modes:

(1) Normal - same function as conventional thermostats.

(2) Temperature adjust - utility radio control to increase temperature setting in $1-1 / 2^{\circ} \mathrm{F}$ steps to a maximum of $82^{\circ} \mathrm{F}$. Customer control is locked out during adjustment. If no utility "refresh" signal is received for fifteen minutes, settings return to normal.

(3) Emergency off - air conditioners are off, regardless of indoor temperatures, in times of system emergencies.

FUNCTION: To adjust thermostats in $1-1 / 2^{\circ} \mathrm{F}$ increments to a maximum of $82^{\circ} \mathrm{F}$, for load relief on most summer days during $12: 30$ p.m. to $6: 30$ p.m. "on peak" period, and to turn off air conditioners during system emergency:

EQUIPMENT: Honeywell electronic single-zone thermostat modified to Pacific Gas and Electric specifications. Motorola and 
Fisher Pierce radio switches. Leased telephone lines to three communities. Redundant Iamsai 8080 minicomputers.

SAMPLE: $\quad 175$ volunteer, non-residential customers in Fresno, 150 in Stockton, and 175 in San Jose, selected from responses to a mailing to 18,000 non-residential customers in the three communities.

INCENTIVE: $\quad \$ 1.50$ per ton on controlled air conditioning capacity per month, May through September.

MONITORING: Magnetic tape recorders at each location monitoring time, total building load, indoor temperature, and air conditioner status at one-minute intervals and synthesized onto a five-minute demand interval tape. Participant attitude interviews before and after the test by a market research firm.

INTERVIEW

DATE :

September 16, 1980.

STATUS: $\quad$ Equipment installation during summer 1978. Tests during summer 1979 and 1980.

RESULTS: $\quad$ Not yet determined. 
THE POTOMAC EDISON COMPANY

REVISED 1980

Downsville Pike

Hagerstown, Maryland 21740

(301) $790-3400$

Joseph R. Staley, Manager, Applications Engineering and Research

SYSTEM: $\quad$ Time and Temperature Switch

SUMMARY: $\quad$ This innovative system was designed, in conjunction with General Electric, to control residential electric heating systems at temperatures below $32^{\circ} \mathrm{F}$ during peak hours, and central air conditioning when temperatures exceed $82^{\circ} \mathrm{F}$. After a successfui trial in ten homes, 300 units have been installed for further testing.

FUNCTION: $\quad$ To cut off electric furnaces and heat pumps when outdoor temperatures are $32^{\circ} \mathrm{F}$ or below, between $9 \mathrm{a} . \mathrm{m}$. and $2 \mathrm{p} . \mathrm{m}$. and 5 p.m. and 9 p.m., with an indoor temperature safety limit of $60^{\circ} \mathrm{F}$ minimum. The house is automatically preheated $4^{\circ} \mathrm{F}$ before heat is cut off. To cycle central air conditioners when outside temperatures reach $82^{\circ} \mathrm{F}$, to a maximum temperature rise in the house of $5^{\circ} \mathrm{F}$.

EQUIPMENT: General Electric prototype time and temperature control device for cycling electric furnaces and air conditioners or heat pumps.

SAMPLE: $\quad 300$ volunteer residential electric heating customers near Hagerstown.

INCENTIVE: $\quad \$ 100$ over two-year demonstration period.

MONITORING: $\quad 60$ units to be metered on magnetic tape. 10 recording thermometers. 
INTERV IEW

DATE:

STATUS:

RESULTS:
May 2, 1980.

Nearing completion. Final report available in July 1980.

Calculations based on a 30,000-customer simulated test, indicate a $7-\mathrm{kW}$ per customer hourly integrated demand load reduction due to this device. Customers reported no significant invconveniences, despite $7^{\circ} \mathrm{F}$ to $8^{\circ} \mathrm{F}$ indoor temperature drop, from the $4^{\circ} \mathrm{F}$ increased preheat temperature drop, after five-hour shutoff. 
TENNESSEE VALLEY AUTHORITY

210 Power Building

Chattanooga, Tennessee 37401

Patricia H. Harris, Chief, 'Load Management Branch

SYSTEM: $\quad$ "Smart Thermostats"

SUMMARY: Tennessee Valley Authority will install and test 50 microprocessor-based thermostats, programmed to control daily thermostat settings. These fifty units are located in homes served by two TVA power distributors. Energy savings, consumer acceptance, load management potential, and reliability will be determined in this one-year test. The units will be divided between consumers on conventional rates and those on time-of-day rates.

FUNCTION: $\quad$ Control of thermostat settings for heating and cooling.

EQUIPMENT: Texas Instruments, Model 4FA2-3.

SAMPLE: $\quad$ Fifty residential consumers.

INCENTIVE: Option to keep the thermostat at test conclusion.

MONITORING: Magnetic tape meters on heating, cooling, and total home load circuits for the time- of-day group.

INTERV IEW

DATE:

January $19,1981$.

STATUS: $\quad$ All equipment installed, test underway.

RESULTS: No load data available; however, positive response to "Smart Thermostat" concept. 


\subsection{MISCELLANEOUS AND SPECIAL PROJECTS}

The eight projects included in this section represent the utilization of new technologies, the specialized use of existing technologies, or largescale projects that involve a mix of two or more types of communication and load control equipment.

An example of the latter category is the project description appearing under the heading of the Nebraska Rural Electric Association. Twentyone of the thirty-three Nebraska Rural Electric. Association member associations are actively involved in the control of irrigation loads through the use of time switches, temperature controls, and radio and ripple systems. The Kansas Electric Cooperatives, Inc. project is similar in the sense that it involves the testing of radio control, temperature control, and manual control of irrigation loads.

Examples of the specialized use of existing technologies are those projects found at Southern California Edison Company and at the Monroe Water, Light and Gas Commission, and the City of Burbank. The Southern California Edison project involves the control of loads in eleven commercial buildings, utilizing a centralized computer system and leased telephone lines. The Monroe Water, Light and Gas Company project uses the basic components of the Scientific Atlanta combination radio and power line carrier system. Instead of using radio as the means of communicating with polemounted receivers, the utility transmits signals over the city-owned cable TV network. Pole-mounted RCX units interface with the cable lines. When the RCX unit receives a proper set of commands, it behaves like the standard hybrid RCX, in that it transmits power line carrier signals over the distribution secondaries to the point-of-control receivers. The City of Burbank project involves the computerized control of loads and remote meter readings at industrial facilities.

Three projects that involve the utilization of new C\&LC systems have been identified.

Tri-County Electric Membership Corporation is testing the British-made cyclocontrol system in conjunction with the Tennessee Valley Authoritysponsored, four-community control program. The cyclocontrol system is similar, in configuration, to a ripple or power line carrier system, 
but differs significantly in signaling technique. In a cyclocontrol signal, a selected number of individual cycles of the supply voltage wave form are altered to reduce the amplitude of the voltage, for a period from about $25^{\circ}$ before to $25^{\circ}$ after a zero crossing. No attempt is made to introduce higher frequencies (as in ripple or power line carrier signaling) or to alter the fundamental frequency of the supply voltage. As such, the signaling is done at the same frequency as the line voltage and provides excellent propagation properties.

Missouri Power and Light Company and New England Electric System are both testing the Emerson Electric TWACS (two-way automatic communications system). This system also differs from ripple or power line carrier systems in its signaling technique. The TWACS signals by altering the time between zero crossings of the $60-\mathrm{Hz}$ sine wave. This alteration is achieved by the addition of a single-cycle $(60-\mathrm{Hz})$ sine wave voltage whose phase angle is displaced by 90 degrees from the supply voltage. The addition of this small modulation voltage ( $1 \%$ of supply voltage) alters the zero crossings of two successive supply voltage cycles. Because the C\&LC systems included in this section represent either previously described systems or new technologies, no attempt is made to develop or discuss utility-incurred costs. 
Miscellaneous C\&LC Equipment Manufacturers

\author{
Emerson Electric Company \\ 8100 W. Florissant - MS-3794 \\ St. Louis, Missouri 63136 \\ GEC Measurements \\ The General Electric Company Ltd. \\ of England \\ Stonefield Works \\ Stone, ST15 ORS, U.K.
}


Table 2-13

Miscel laneous and Special Projects Sumary

\begin{tabular}{|c|c|}
\hline Utilitity & Contact \\
\hline City of Burbank & $\begin{array}{l}\text { James D. Woodburn, Chief Engineer } \\
\{213\} \text { 847-9650 }\end{array}$ \\
\hline $\begin{array}{l}\text { Kansas Electric Cooperatives, } \\
\text { Inc. }\end{array}$ & $\begin{array}{l}\text { Lester Murphy, Operations Manager } \\
(913) 272-8740\end{array}$ \\
\hline $\begin{array}{l}\text { Missouri Power and Light } \\
\text { Company }\end{array}$ & $\begin{array}{l}\text { Larry Rushing, Project Manager } \\
\text { (314) } 635-0171\end{array}$ \\
\hline $\begin{array}{l}\text { Monroe water, Light, and } \\
\text { Gas Commission }\end{array}$ & $\begin{array}{l}\text { John } 8 \text { risco, Superintendent } \\
(404) 267-5756\end{array}$ \\
\hline $\begin{array}{l}\text { Nebraska Rural Electric } \\
\text { Association }\end{array}$ & $\begin{array}{l}\text { 8ob Mcculloch, Director, Special Services } \\
(402) 4475-4988\end{array}$ \\
\hline $\begin{array}{l}\text { New England Electric } \\
\text { System }\end{array}$ & $\begin{array}{l}\text { George Saki lar is, Director, Load Management } \\
(517) 3_{366-9011}\end{array}$ \\
\hline $\begin{array}{l}\text { Southern Cal ifornia } \\
\text { Edison Company }\end{array}$ & $\begin{array}{l}\text { Eir. A. Myers, vice President } \\
\text { (213) }\end{array}$ \\
\hline $\begin{array}{l}\text { Tri-County Electric } \\
\text { Membership Corporation }\end{array}$ & $\begin{array}{l}\text { Ralph Law, Systems Engineer } \\
(615) 666-2111\end{array}$ \\
\hline 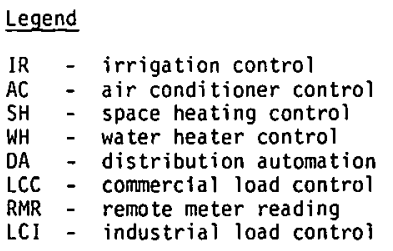 & \\
\hline
\end{tabular}

\begin{tabular}{|c|c|c|c|c|c|}
\hline $\begin{array}{l}\text { Equipment } \\
\text { Lockheed } 7600 \\
\text { Control ystem } \\
\text { IIT Comuni ication } \\
\text { system }\end{array}$ & $\begin{array}{l}\text { Control } \\
\text { Eunction(s) } \\
\text { RMRR-LCI }\end{array}$ & $\frac{\begin{array}{c}\text { Mumber } \\
\text { of Points }\end{array}}{5}$ & $\begin{array}{c}\frac{\text { Class }}{\text { Demonstration }} \\
\text { D. }\end{array}$ & $\begin{array}{c}\begin{array}{c}\text { Status } \\
\text { Partially } \\
\text { in service }\end{array} \\
\text {. }\end{array}$ & $\begin{array}{l}\text { Incentive } \\
\text { Lower demand charges }\end{array}$ \\
\hline $\begin{array}{l}\text { Thermostats } \\
\text { and radio }\end{array}$ & IR & Unknown & Demonstration & $\begin{array}{l}\text { 3rd year of } \\
\text { testing }\end{array}$ & None \\
\hline twacs & AC--HH-SH-RMR & 150 & Demonstration & $\begin{array}{l}\text { Partially } \\
\text { in service }\end{array}$ & \$24/year \\
\hline $\begin{array}{l}\text { Scientific } \\
\text { Attanta } \\
\text { cable-plc }\end{array}$ & $A C$ & 200 & Systemwide & $\begin{array}{l}\text { Partially } \\
\text { in service }\end{array}$ & None \\
\hline $\begin{array}{l}\text { Radio, ripple, } \\
\text { time switches, } \\
\text { temp. switches }\end{array}$ & IR & $\begin{array}{l}14 \text { rural } \\
\text { utilitios }\end{array}$ & Systemwide & In service & Various'special rate schedules \\
\hline Thacs & DA-RMR-WH & 150 & Demonstration & In service & None \\
\hline $\begin{array}{l}\text { Prime computer, } \\
\text { leased telephone } \\
\text { lines to }\end{array}$ & LCC & 11 buildings & Demonstration & In service & Demand rate \\
\hline Cyclócontrol & WH-AC-SH & 105 & Demonstration & In service & $\begin{array}{l}\text { Up to } \$ 90 \text { total for duration } \\
\text { of test }\end{array}$ \\
\hline
\end{tabular}

Results/Remarks
Control and te lemetering
successful to date.

Peak demind reductions achieved
without signini ficantly affecting
crop yields

Not yet determined

Not yet determined.

Total systemwide savings for
1978 estimated at $\$ 1.5$ million.

Success with bidirectional
signalling.

Expect 17\%- $25 \%$ load reduction
from group.

Excel lent signal reliability
Systemidide program begins
surmer 1980 . contact date August 10, 1978

August 31, 1977 September 4, 1980

October 28, 1980

Apri1 21, 1980 Apri1 29, 1980 Apri1 29, 1980 May 1, ig80 
THIS PAGE

WAS INTENTIONALLY

LEFT BLANK 
CITY OF BURBANK

164 West Magnolia Boulevard

Burbank, California 91503

James D. Woodburn, Chief Engineer
REVISED 1978

(213) $847-9650$

SYSTEM: $\quad$ Computer Control and Telemetering

SUMMARY: A test is being conducted to determine the feasibility of utility-controlled load management for industrial customers. The test includes energy audits, load control, and remote metering. Loads not directly involved in production are cycled for energy reduction and peak demand limitation. Loads are monitored via remote metering and load profiles are displayed on a CRT at the utility's dispatch center. The project is to provide design and cost-benefit analysis to be used in implementing utility-controlled load management. Control and metering signals are transmitted over utility's communications lines. Funding is by DOE/ORNL and is an expansion of a previous load management test that was partially funded by APPA.

FUNCTION: Control, by computer, of nonessential loads at industrial customer facilities, and remote metering of customer demand and energy usage.

EQUIPMENT: Control - Lockheed Electronics Corporation 7600 System. Remote Metering - International Teldata Corporation.

SAMPLE: Control and remote metering for three industrial customers and energy audits and remote metering for 10 other industrial customers.

INCENTIVE: Energy conservation, lower demand charges. 
MONITORING: Load profiles via remote metering. Effect of control on production and employee comfort.

INTERIVEW

DATE:

August 10, 1978.

STATUS:

Control and remote metering systems are in service for one customer. Installation of equipment for two additional customers is in progress.

RESULTS: Controi and tclemetcring functions have been suciessful to date.

REMARKS: CB's system load is $45 \%$ industrial and only $25 \%$ residential, hence the effort toward industrial load control.

Final report now being published. 
MISSOURI POWER \& LIGHT COMPANY

NEW 1980

101 Madison Street

Jefferson City, Missouri 65101

(415) $781-4211$

Larry Rusining, Project Manager

SYSTEM: $\quad$ Power Line Voltage Wave Modification (TWACS)

SUMMARY: Missouri Power \& Light Company will demonstrate the communication capability of the TWACS concept for timeof-day metering control, remote meter reading, load research, remote capacitor, and substation switching. A special test wi11 be conducted, in which three 12.5-kV distribution circuits will be tied together to determine TWACS effectiveness at distances of up to 50 miles.

FUNCTION: Automated distribution and control of residential air conditioning, water heating, and space heating.

EQUIPMENT: Emerson Electric Company - TWACS.

SAMPLE: $\quad$ Fifty residential air conditioners, water heaters, and electric heat systems. One hundred meters for remote reading. Several capacitor banks and substations.

INCENTIVE: $\quad \$ 24$ per year.

INTERVIEW

DATE:

September 4, 1980.

STATUS: Partially installed. Tests to start by November 1980.

MONITORING: Nul yel delermined.

RESULTS: $\quad$ Preliminary test indicates $99 \%$ reliability up to 20 miles. 
MONROE WATER, LIGHT \& GAS COMMISSION

215 North Broad Street

P.0. Box 725

Monroe, Georgia 30655

NEW 1980

John Brisco, Superintendent

SYSTEM: $\quad$ Combination Cable TV and Power Line Carrier

SUMMARY: $\quad$ This program of air conditioner cycling involves a unique application of the Scientific Atlanta hybrid system hardware. In the standard hybrid system, a VHF radio system is used to communicate with transponders mounted on distribution poles. These transponders (RCS units) receive radio signals and respond by injecting power line carrier signals onto the distribution secondaries. In this program, the city-owned cable TV network, rather than radio, is utilized as the primary communication link. The pole-mounted RCX units are interfaced with the cable network. Load control commands are broadcast via cable, received by the RCX units, and then translated and injected as power line carrier signals onto the distribution line.

FUNCTION: Cycle commercial and residential air conditioners. Control municipal water pumping operations.

EQUIPMENT: $\quad$ Sclentific Atlanta load control receivers and pole-mounted transponders with cable TV interfaces.

SAMPLE: $\quad$ Two hundred commercial and residential customers. Program is avallable to all customers with central alr conditloners.

INCENTIVE: None.

INTERVIEW

DATE:

October 28, 1980. 
STATUS: Partially in service.

RESULTS: $\quad$ Not yet determined. 
NEBRASKA RURAL ELECTRIC ASSOCIATION

Box 82048

REVISED 1980

Lincoln, Nebraska 68501

(402) $475-4988$

Bob McCulloch, Director Special Services

SYSTEM: $\quad$ Irrigation Control Via Radio, Ripple, and Time Switches

SUMMARY: $\quad$ Twenty-one of the thirty-three rural electric associations in Nebraska are actively involved in irrigation load control. Although seven of these distributors rely solely on the voluntary cooperation of irrigators to limit pump operation during peak periods, fourteen rural electric associations have installed local or remote control systems to eurtail pumping. Four ripple and seven radio systems are now in service, and several other rural electric associations are utilizing time and/or temperature switches. At least seven other rural electric associations are planning to institute load control in the near future.

FUNCTION: $\quad$ Ripple, radio, and time switch systems switch irrigation pump motors off and on during peak summer days, in accordance with contract provisions.

EQUIPMENT: Ripple systems are by Plessey Company. Radio systems in operation are by Motorola, Plectron, or Fisher Pierce.

SAMPLE: $\quad$ Fourteen of Nebraska's rural electric associations are involved in direct irrigation control. They are:

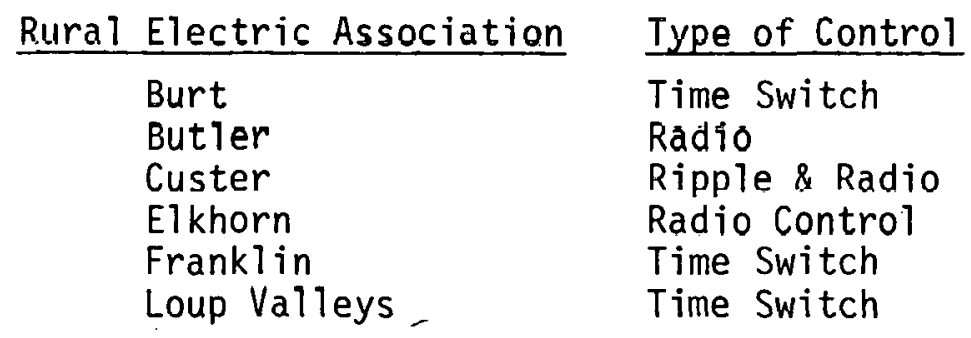




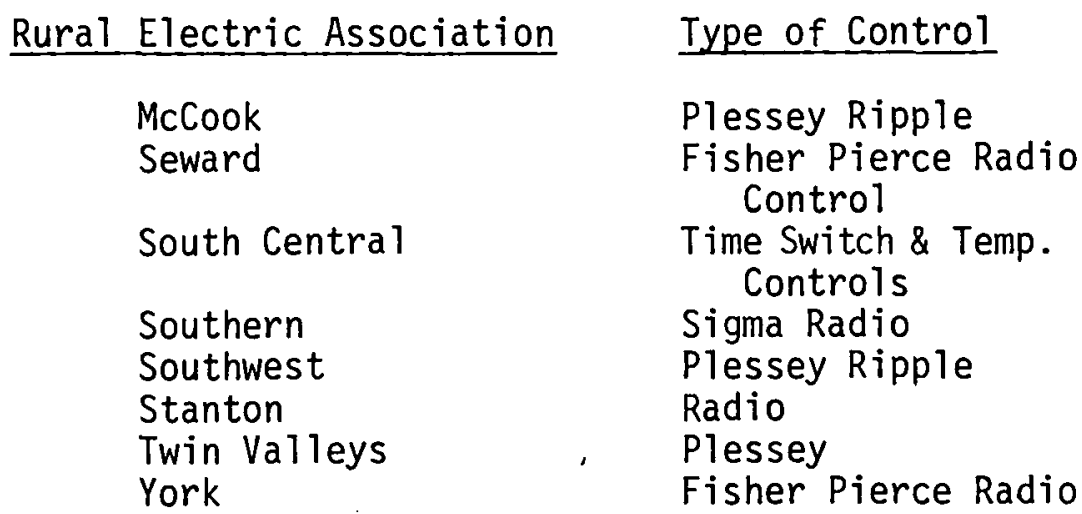

INCENTIVE: Retail rate incentives result in savings to controlled irrigators, ranging from $\$ 500$ to $\$ 1500$ per year.

Weekly control rates permit utility load interruption on one selected day of the week. Daily control rates permit utility load interruption on any day and probably more than one day per week.

Rate reductions, based on connected hp, vary from $3 \notin$ to $1 / 2 \$$ per kWh by quantity and control frequency.

INTERVIEW

DATE:

Apri1 21, 1980.

STATUS: Ongoing.

RESULTS: Nebraska Rural Electric Association estimates that the total demand ratchet savings resulting from irrigation control in 1978 were as high as $\$ 1.5$ million statewide. 
NEW ENGLAND ELECTRIC SYSTEM

REVISED 1980

25 Research Drive

Westborough, Massachusetts 01581

(617) $366-9011$

George Sakillaris, Director, Load Management

SYSTEM: $\quad$ Power Line Voltage Wave Modification

SUMMARY: As a result of the successful trial of the prototype bidirectional systems, TWACS, New England Electric System will begin a 150-point demonstration program in the summer of 1980. The demonstration program will evaluate the capabilities of the commercial version of the system by performing various distribution automation and load management functions. Phase and neutral injection will be demonstrated.

FUNCTION: Perform remote meter reading (including time-of-day), distribution automation (capacitor banks), load control (water heaters), T.0.U. metering, and load and rate research data collection.

EQUIPMENT: The commercial version of the system has been developed and will be manufactured by Emerson Electric Company.

SAMPLE: $\quad 150$ points with:
A.M.R. on 163 meters
Load contrul on 54 meters
Time-of-use metering on 163 meters
Load research on 163 meters
Distribution automation at 4 locations
Communications assessment at 36 locations

INCENIIVE: None.

MONITORING: A.M.R. capability of the equipment. 
$2-183$

INTERVIEW

DATE :

STATUS:

RESULTS:
April 28, 1980.

In service.

Not yet determined. 
SOUTHERN CALIFORNIA EDISON COMPANY

P.0. Box 800

Rosemead, California 91770

REV ISED 1980

E.A. Myers, Vice President

SYSTEM: $\quad$ Multiple Building Peak Demand Control

SUMMARY: $\quad$ Four large corporations located in ten buildings are banding together in a test program to reduce the coincident load of the group to meet Edison's peak demand constraints. These customers will be linked togcther through the use of a computer-based energy information center that will monitor individual building loads, as well as the combined group load, and will communicate load restraints to these customers in an effort to meet the load management goals of the test program.

FUNCTION: The system will monitor the coincident demand of the group and provide load shedding information to the memhers of the group in an effort to keep the daily coincident peak demand below a preset level.

EQUIPMENT: A remotely located Prime 3, 0ก0 minir.nmputer, connected, through leased telephone lines, to Dorado microprocessors located at the customer locations.

SAMPLE: $\quad$ Ten commercial buildings consisting of office buildings and one enclosed shopping mall.

INCENTIVE: Energy conservation and lower individual building blling charges.

MONITORING: Minicomputer. 
INTERVIEW

DATE :

May 1, 1980:

STATUS: On July 1, 1980 this project's one-year test will be completed. After July 1, the program will be permanent.

RESULTS: $\quad$ To be determined.

REMARKS: $\quad$ Expect 4-6 MW reduction of group coincident peak demand (existing group coincident peak demand is $24 \mathrm{MW}$ ). With a successful test program, the system may be continued on a permanent basis. 
$2 \cdot 186$

THIS PAGE

\section{WAS INTENTIONALLY LEFT BLANK}


ORNL/Sub-80/13644/1

Dist. Category UC-97b

Internal Distribution

1. R. K. Adams

2. T. D. Anderson

3. H. G. Arnold

4. P. R. Barnes

5. S. E. Beall, Jr.

6. H. I. Bowers

7. B. W. Brummitt

8. G. L. Campen

9. R. S. Carlsmith

10. F. C. Chen

11. G. E. Courville

12. F. A. Creswick

13. G. A. Cristy

14. G: A. Daley

15. R. M. Davis

16. M. D. Eden

17. R. D. Ellison

18. P. D. Fairchild

19. W. Fulkerson

20. S. R. Greene

21. V. 0. Haynes

22. W. T. Jewell

23. S. I. Kaplan

24. M. A. Karnitz

25. M. A. Kuliasha
26. A. S. Loebl

27. F. W. Manning

28. B. W. McConnell

29. J. M. McIntyre

30. J. M. Michel

31.. R. E. Minturn

32. W. R. Mixon

33. W. P. Poore

34. H. Postma

35. S. L. Purucker

36. T. W. Reddoch

37. D. T. Rizy

38. M. W. Rosenthal

39. G. Samuels

40. R. B. Shelton

41-90. D. J. Slaughter

91. J. P. Stovall

92. T. J. Wilbanks

93. H. E. Zittel

94-95. Central Research Library

96. Document Reference Section

97-98. Laboratory Records Department

99. Laboratory Records. (RC)

100. ORNL Patent Office

101. Y-12 Technical Library

\section{External Distribution}

102. Office of Assistant Manager for Energy Research and Development, Department of Energy, Oak Ridge Operations, Oak Ridge, TN 37830

103. J. R. Gracia, Department of Energy, Oak Ridge Operations, Oak Ridge, TN 37830

104. R. D. Dunlop, Department of Energy, Division of Electric Energy Systems, 12th and Pennsylvania Avenue, Washington, DC 20461

105. K. W. Klein, Department of Energy, Division of Electric Energy Systems, 12th and Pennsylvania Avenue, Washington, DC 20461

106. D. Roesler, Department of Energy, Division of Electric Energy Systems, 12th and Pennsylvania Avenue, Washington, DC 20461 
107-156. Joseph C. Skroski, Department of Energy, Division of Electric Energy Systems, 12th and Pennsylvania Avenue, Room 6144, Washington, DC 20461

157. J. C. Smith, Department of Energy, Division of Electric Energy Systems, 12th and Pennsylvania Avenue, Room 6144, Washington DC 20461

158-1845. Mailing list for Electric Energy Management News

1846-2100. Given for distribution as shown in DOE/TIC-4500 under Category UC-97b (Electric Energy Systems Power Distribution). 

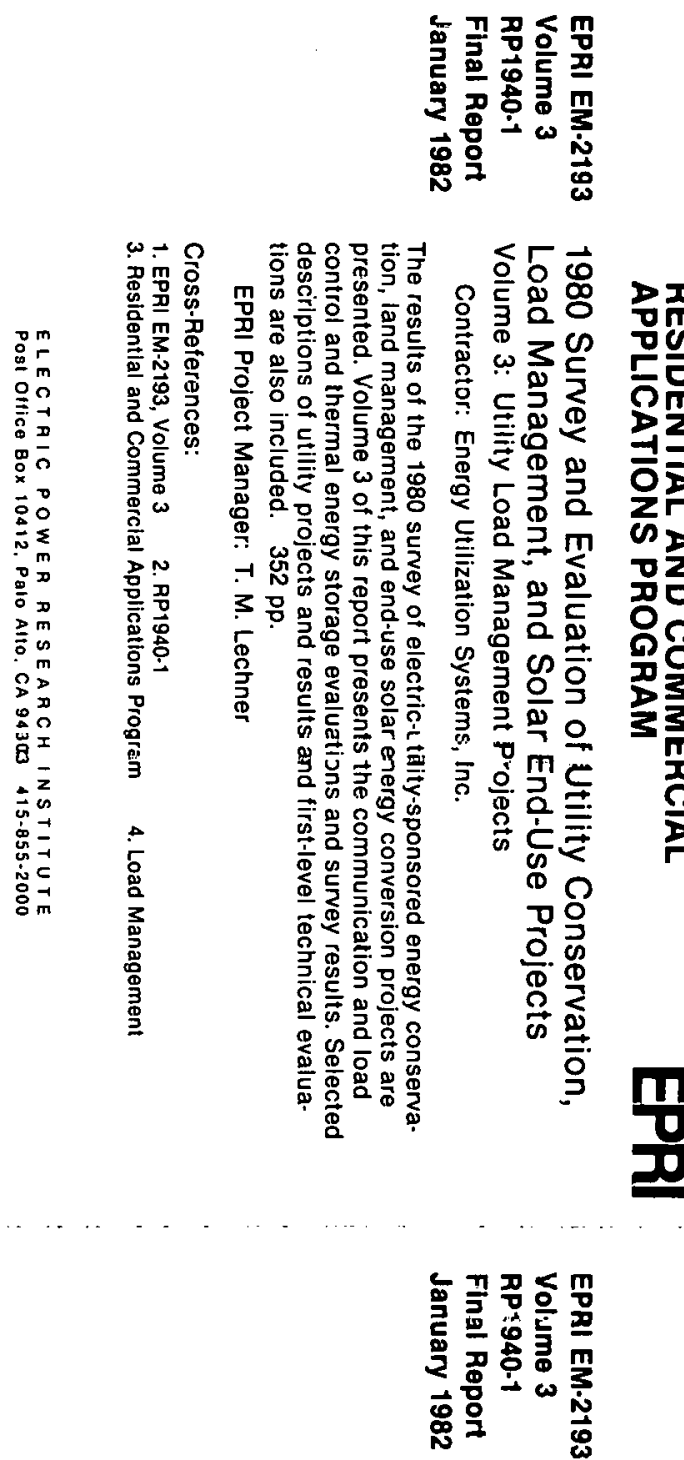

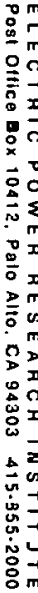

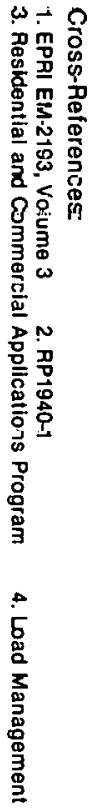

Below are five index cards that allow for filing according to the four cross-references in addition to the title of the report. A brief abstract describing the major subject area covered in the report is included on each card.

\section{EPRI EM.2193 \\ Volume 3 \\ RP1940-1 \\ Final Report \\ 1980 Survey and Evaluation of Utility Conservation, Load Management, and Solar End-Use Projects \\ Volume 3: Utility Load Management Projects \\ Contractor: Energy Utilization Systems, Inc.}

January 1982

EPRI EM-2193 Volume 3 RP1940.1 Final Report January 1982

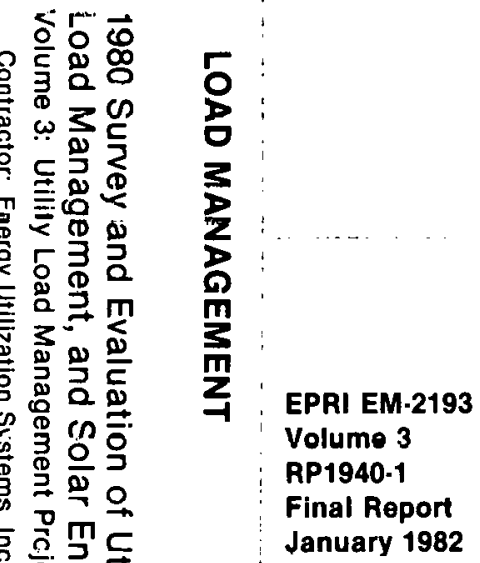
January 1982
The results of the 1980 survey of electric-utility-sponsored energy conservation, land management, and end-use solar energy conversion projects are presented. Volume 3 of this report presents the communication and load control and thermal energy storage evaluations and survey results. Selected descriptions of utility projects and results and first-level technical evaluations are also included. $352 \mathrm{pp}$.

EPAI Project Manager: T. M. Lechner

Crose-Referenras:

$\begin{array}{ll}\text { 1. EPRI EM-2193, Volume } 3 & \text { 2. RP1940-1 }\end{array}$

3. Residential and Commercial Applications Program 4. Load Management

ELECTRIC POWEA RESEARCH INSTITUTE POBt Oftice BOA 10412. PalO Al10 CA 94303 415-855-2000

\section{EPRI EM-2193, VOLUME 3}

\section{EPR}

1980 Survey and Evaluation of Utility Conservation, Load Management, and Solar End-Use Projects Volume 3: Utility Load Management Projects

Contractor: Energy Utilization Systems, Inc.

The results of the 1980 survey of electric-utility-sponsored energy conservation, land managerrietil, and end-use soler onergy conversion projerts are presented. Volume 3 of this report presents the communication and load control and thermal energy storage evaluations and survey results. Selected descriptions of utility projects and results and first-level technical evaluations are also included. $352 \mathrm{pp}$.

EPRI Project Marlayer: T. M. Lechner

Cross-References:

1. EPRI EM-2193, Volume 3 2. RP1940-1

3. Residential and Commcroial Applications Program 4. Load Management

ELEGTNIG POWER RESFARCH INSTITUTE

Post Ollice Box 10412. Palo Alto, CA 94303 415-855-2000

\section{RP1940-1}

1980 Survey and Evaluation of Utility Conservation, Load Management, and Solar End-Use Projects

Volume 3: Utility Load Management Projects

Contractor: Energy Utilization Systems, Inc.

The resulls of the 1980 survoy of elestric-utility-sponsored energy conservatlon, land management, and end-use solar energy conversion projects are presented. Volume 3 of this report presents the communication and load curitrul and thermal onorgy storage evaluations and survey results. Selected descriptions of utility projects and results and first-level technical evaluations are also included. $352 \mathrm{pp}$.

EPRI Project Manager: T. M. Lechner

Cross-References:

1. EPRI EM-2193, Volume $3 \quad$ 2. RP1940-1

3. Residential and Commercial Applications Program 4. Load Management 